Fall 1960

\title{
1960 Miracle Yearbook
}

\section{Cedarville College}

Follow this and additional works at: https://digitalcommons.cedarville.edu/yearbooks

Part of the Higher Education Commons, Organizational Communication Commons, and the Public Relations and Advertising Commons

\section{Recommended Citation}

Cedarville College, "1960 Miracle Yearbook" (1960). Yearbooks. 42.

https://digitalcommons.cedarville.edu/yearbooks/42

This Book is brought to you for free and open access by DigitalCommons@Cedarville, a service of the Centennial Library. It has been accepted for inclusion in Yearbooks by an authorized administrator of DigitalCommons@Cedarville. For more information, please contact digitalcommons@cedarville.edu. 


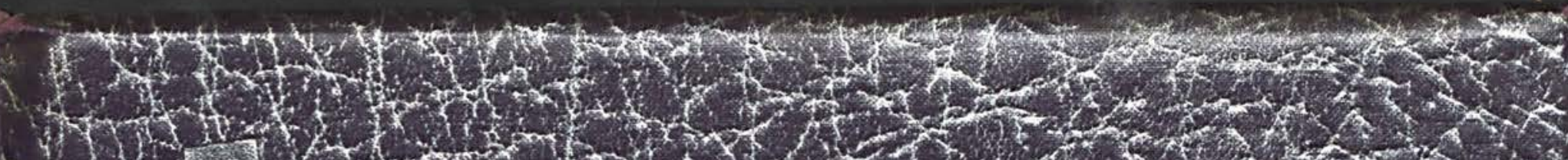

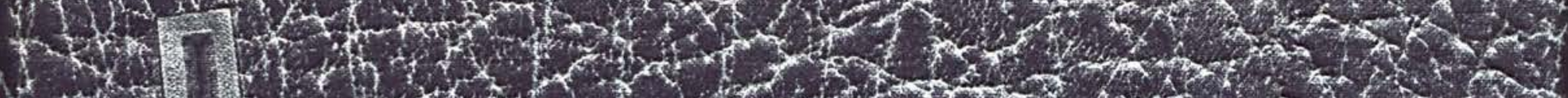

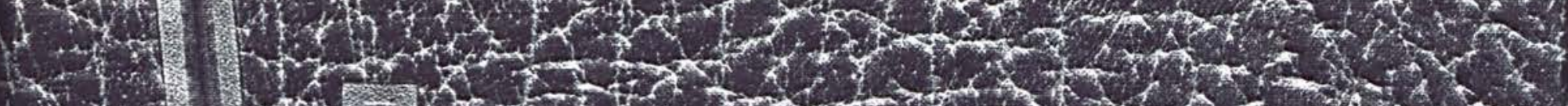
(1)

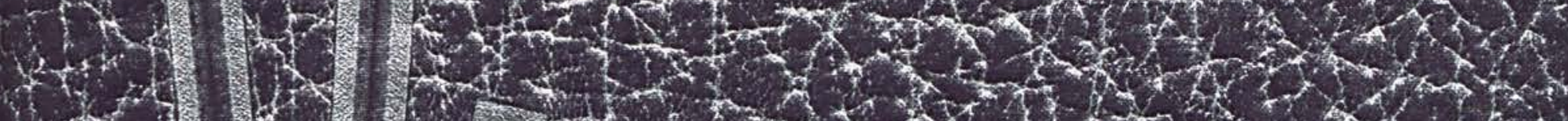

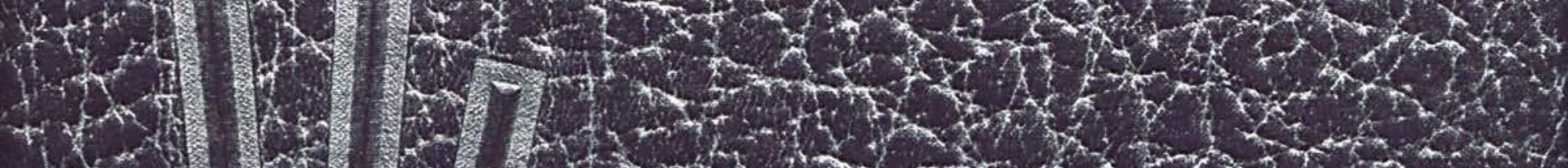
$10 x^{\circ}: 4$

(3) $x+\pi+2$

$p+x \rightarrow \frac{1}{2}$

$x^{4}+x^{2}, x^{2}$

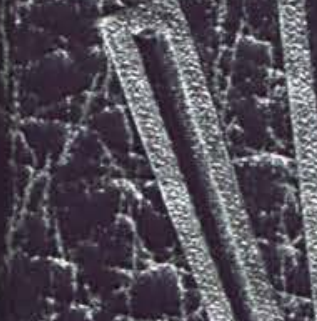

$43^{2}+y^{2}$

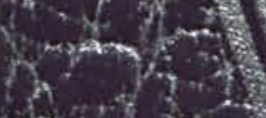

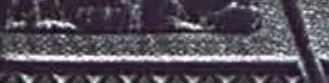

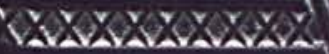

\section{Miracle}

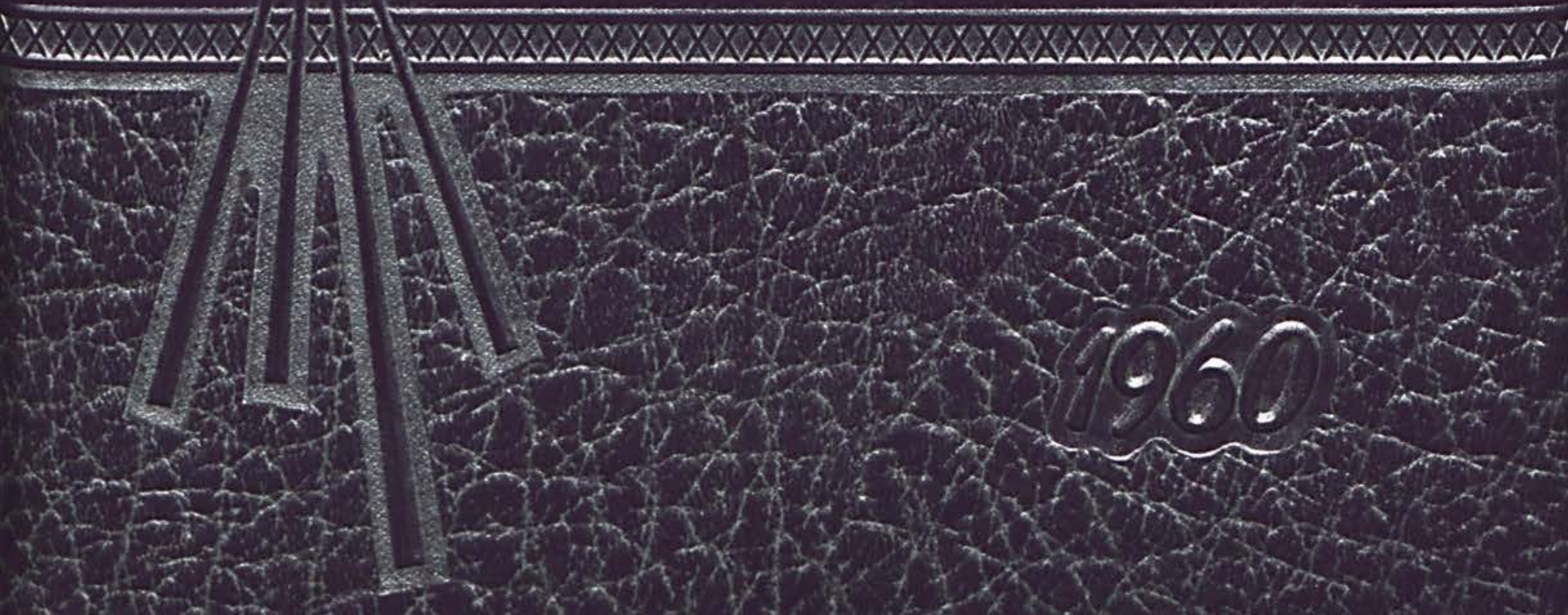




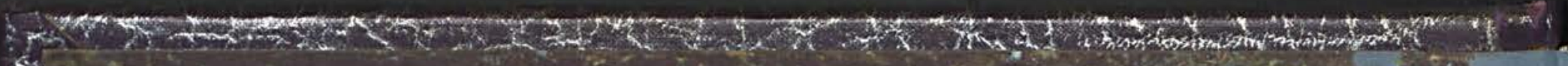

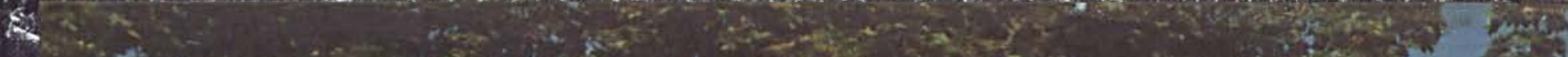

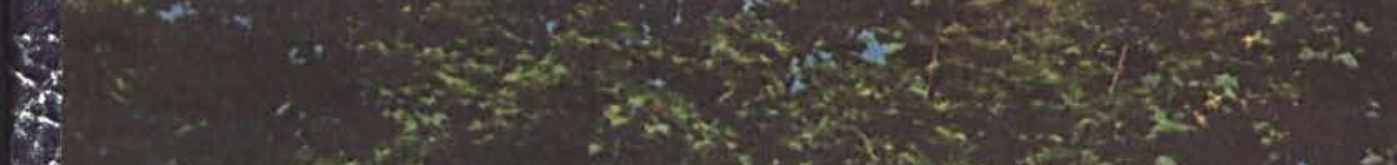

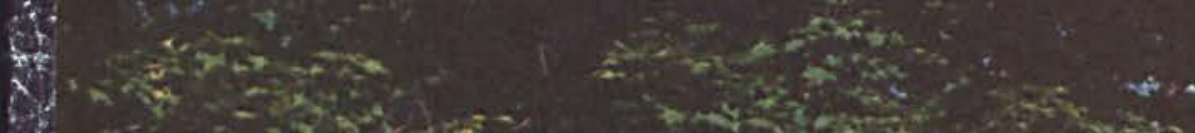

(3)

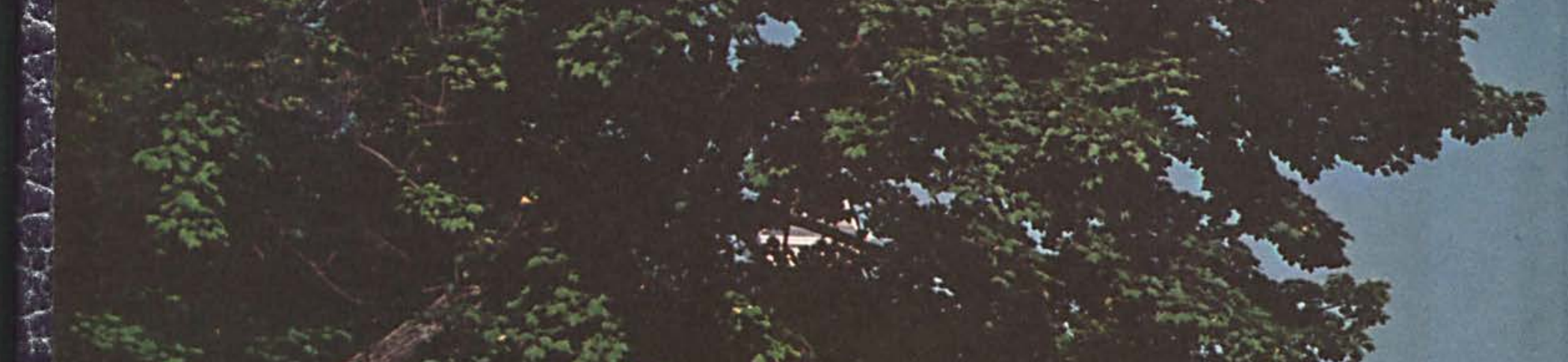

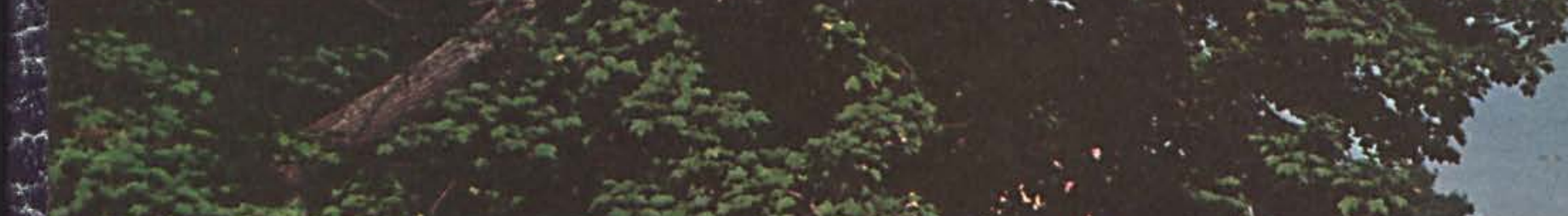

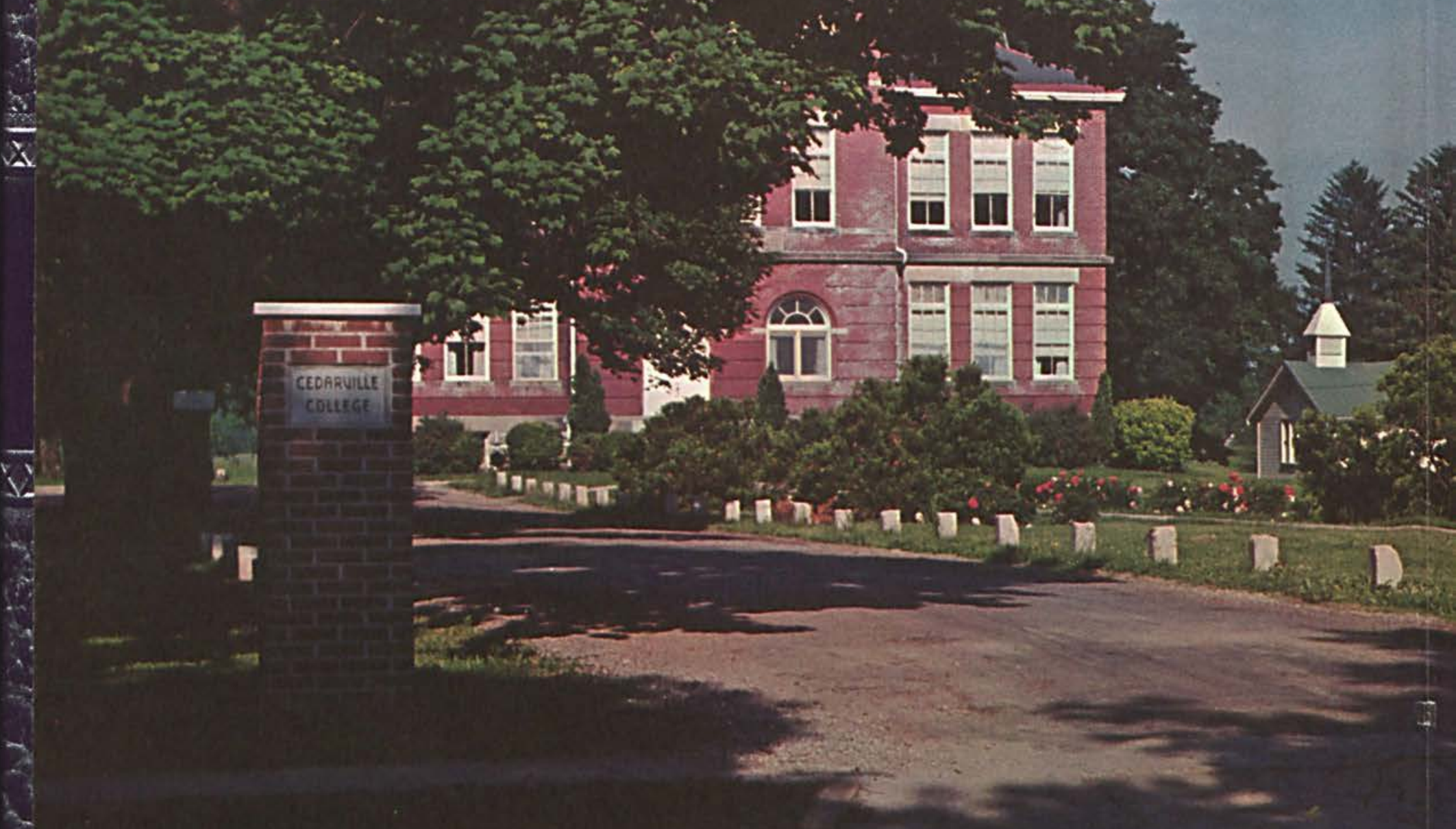



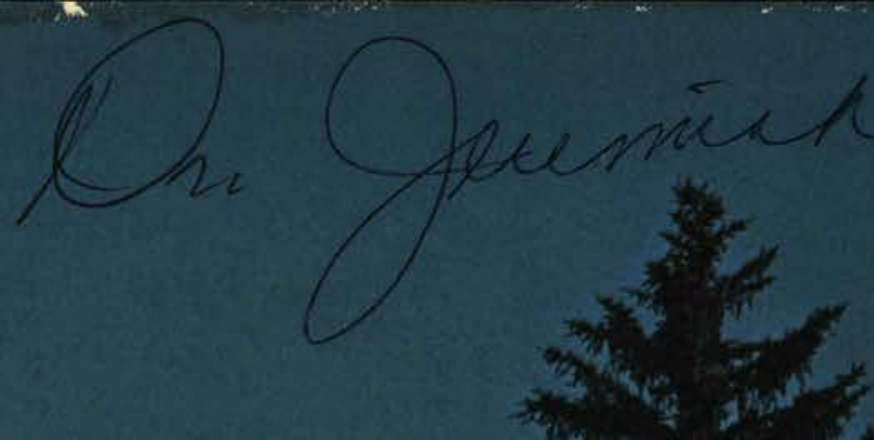

3 is

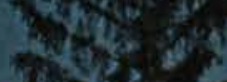

wing

(N)

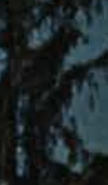

6)

Then

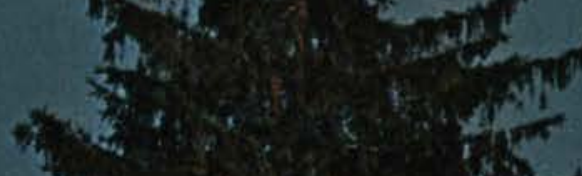

$x+3$

The ist
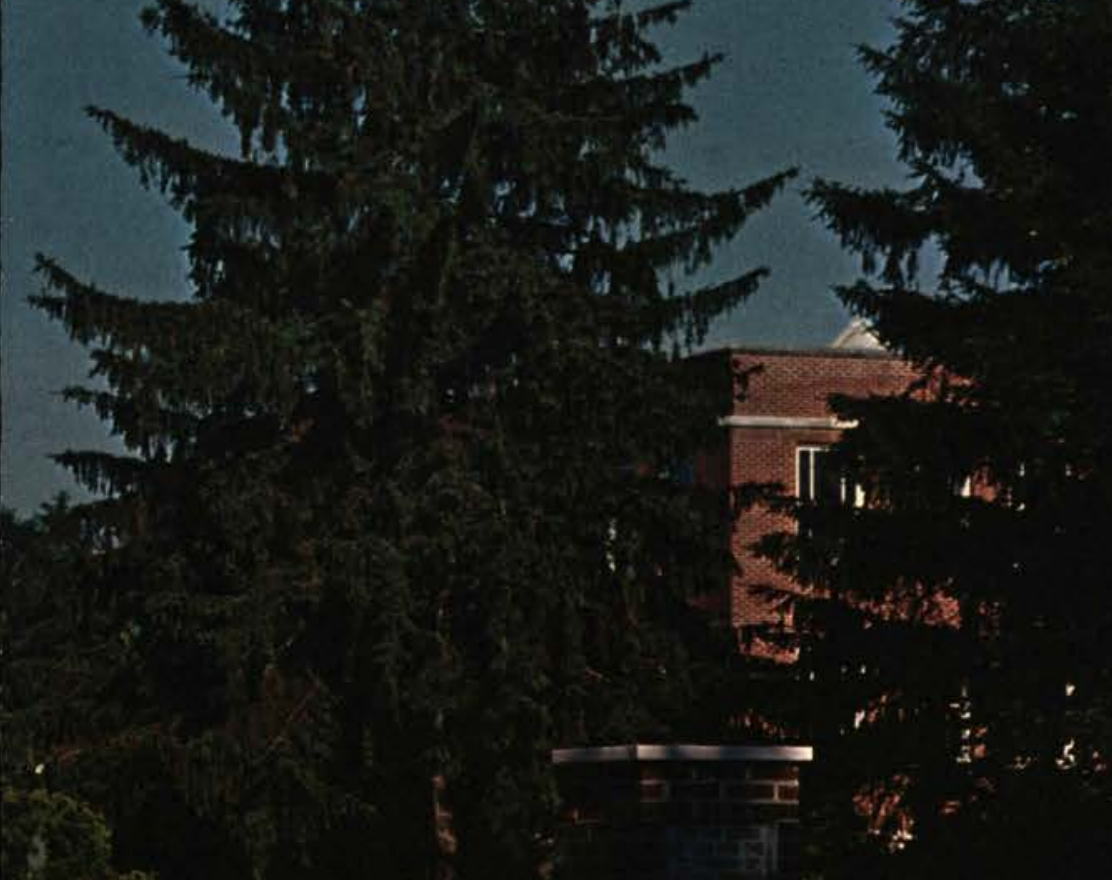




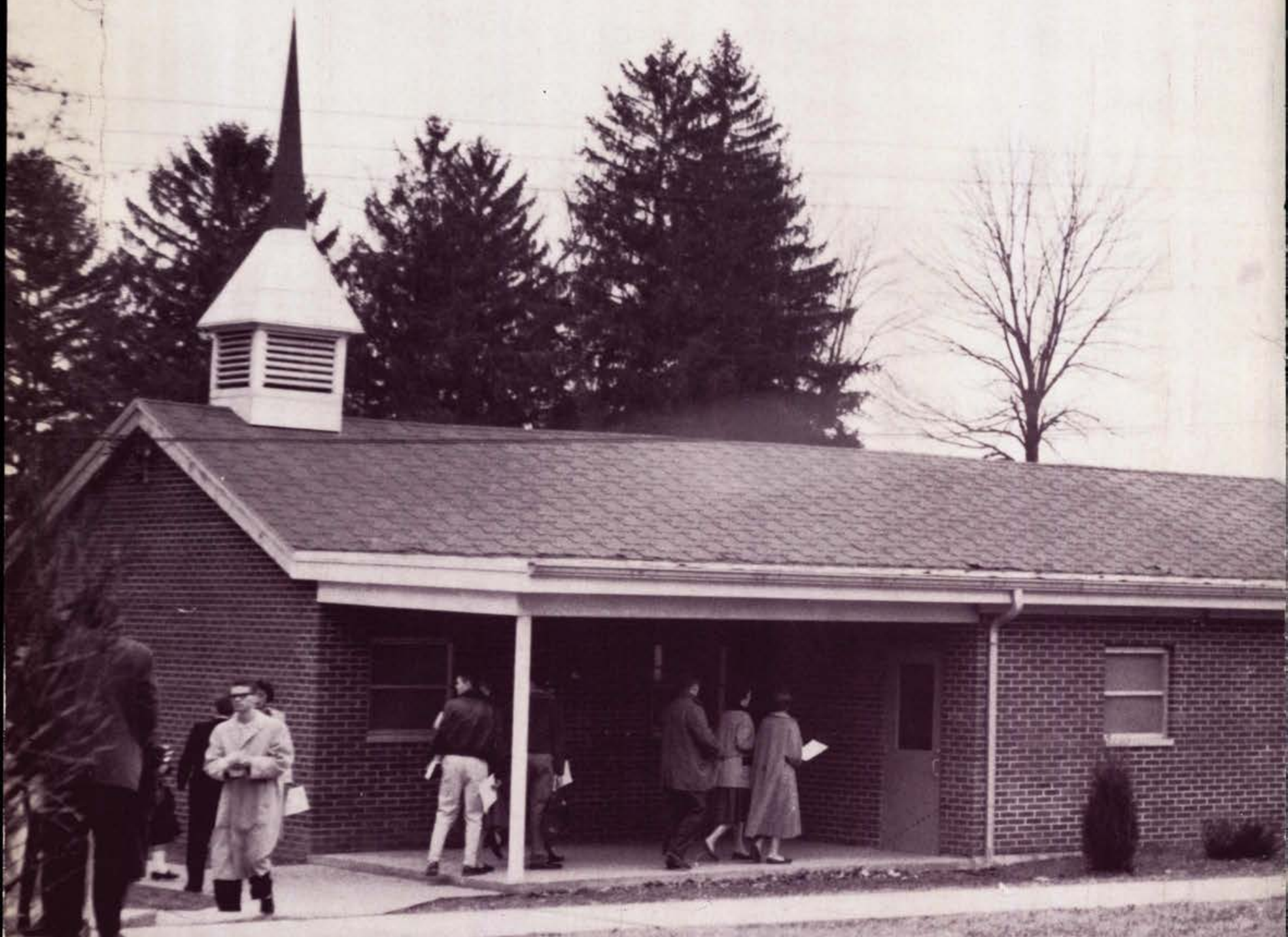



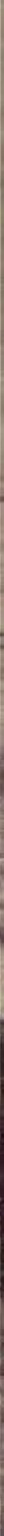

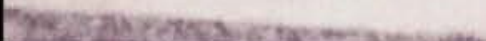

\section{The Miracle}




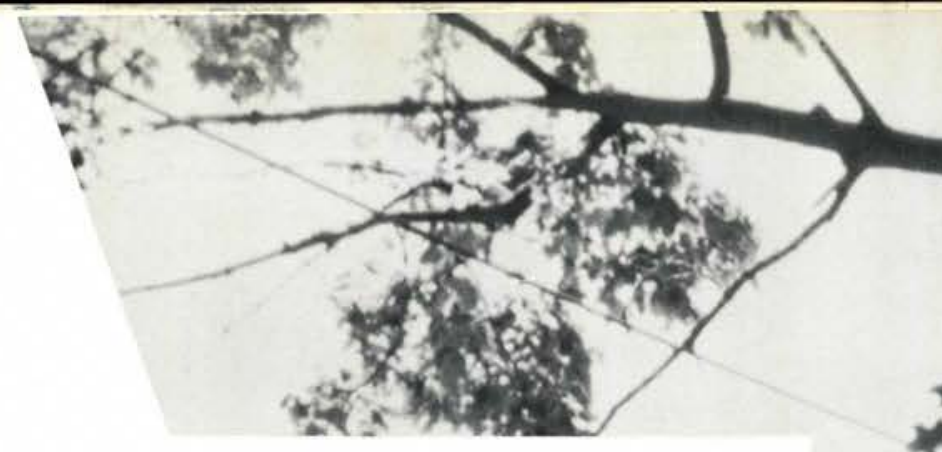

\section{Foreword}

Knowing that our Source of light will never cease, we are sure that the pleasures and progress reflected on these pages are but a foreshadowing of brighter things to come.

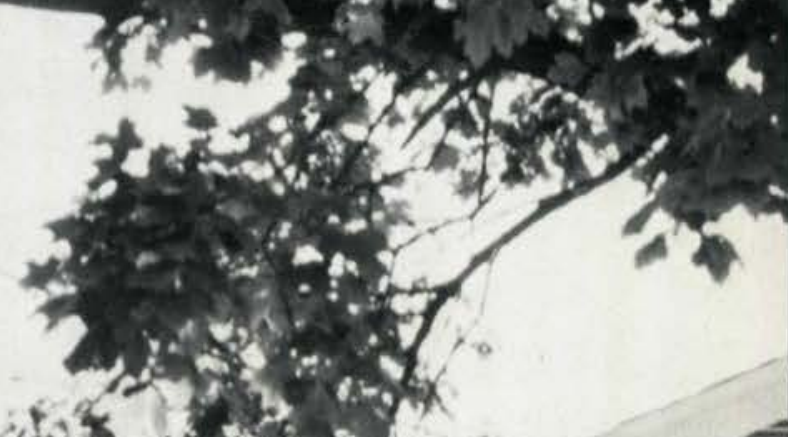

$6 x^{2}+2:-2 x$
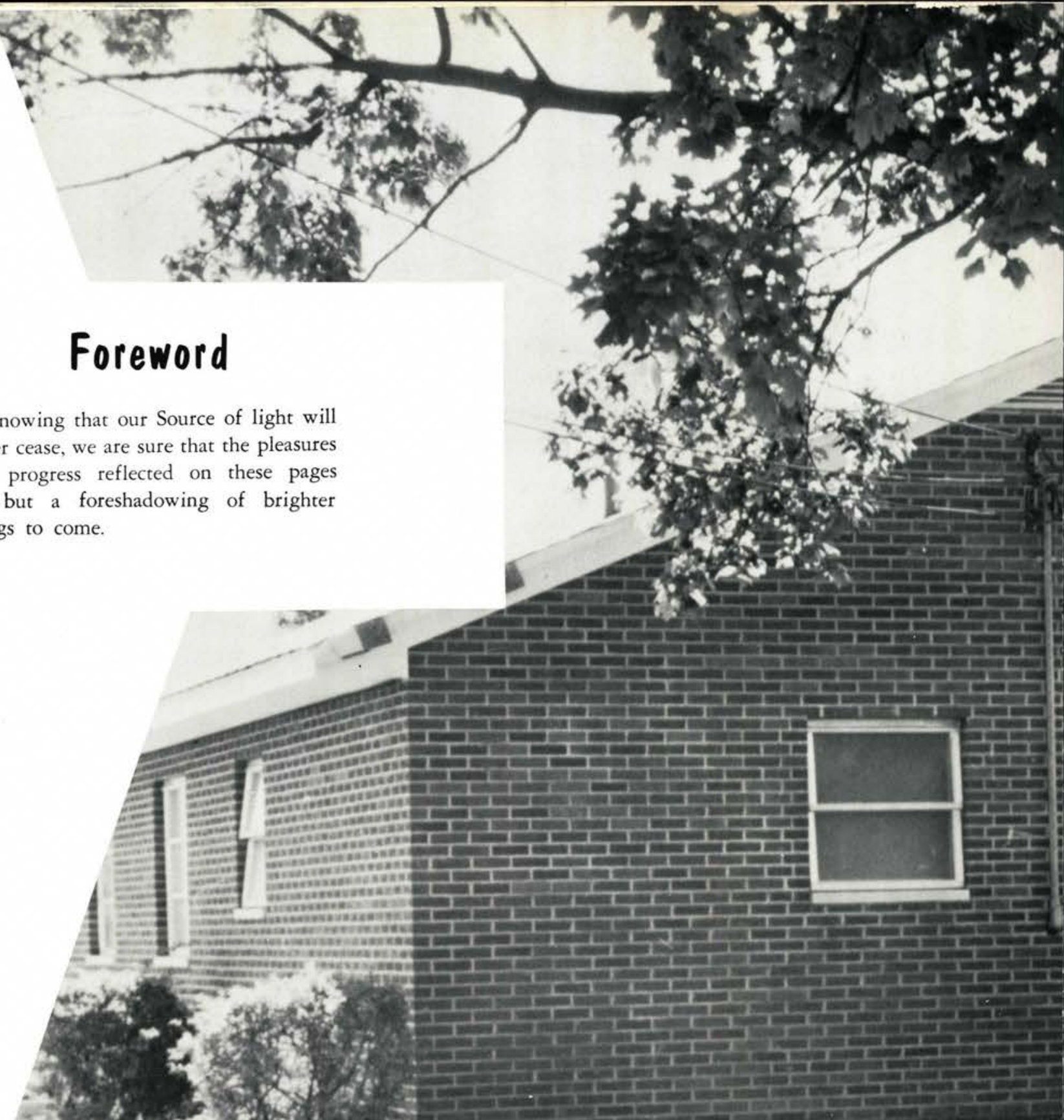

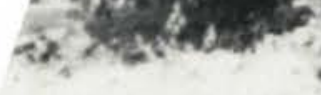
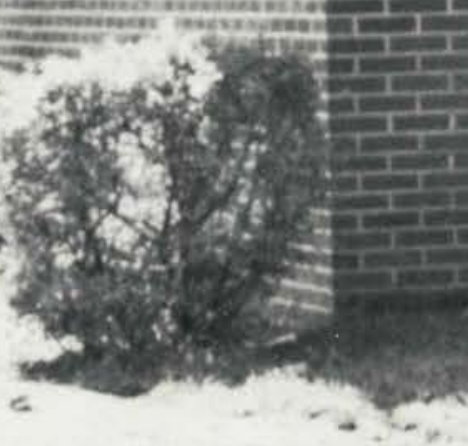


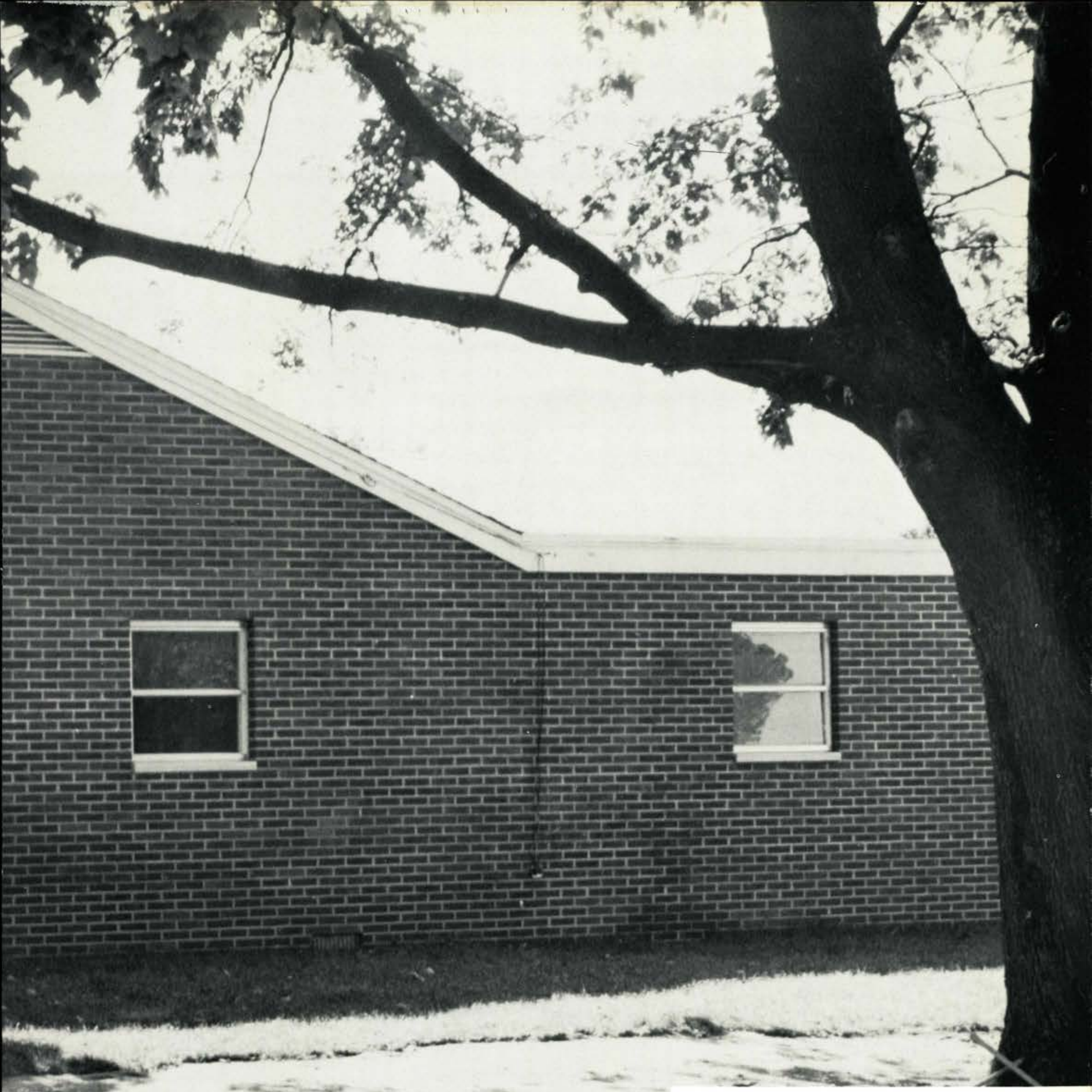

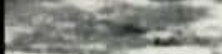

angasing

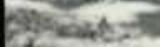

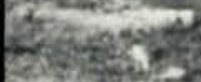

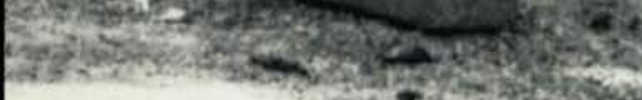
twate:

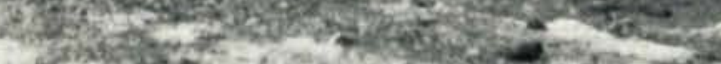

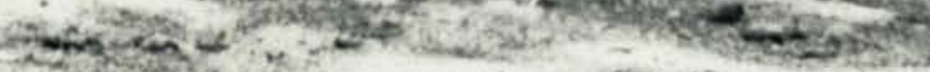

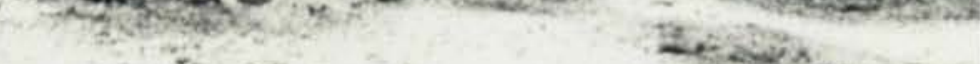

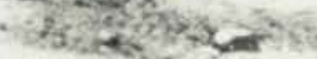

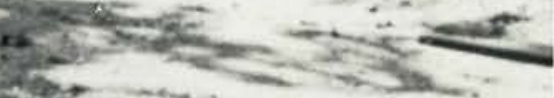

Rising 8

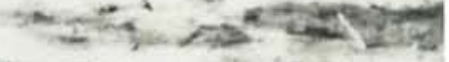
storitis

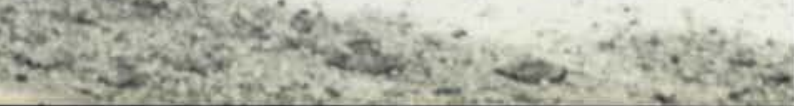

\section{Table of Contents}

INTRODUCTION

FACULTY

Activities

organization

music

Christian service

sports

social highlights

\section{STUdENTS}




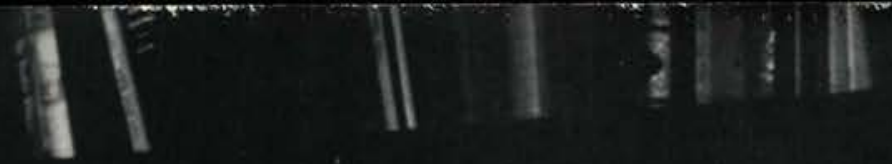

$$
\begin{aligned}
& = \\
& \text { 落 }
\end{aligned}
$$

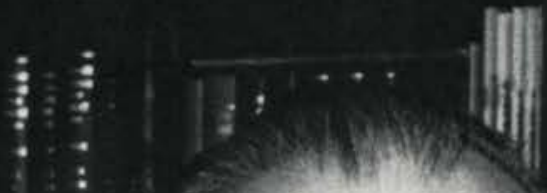$$
6
$$$$
4\left(\frac{100}{6}\right)
$$

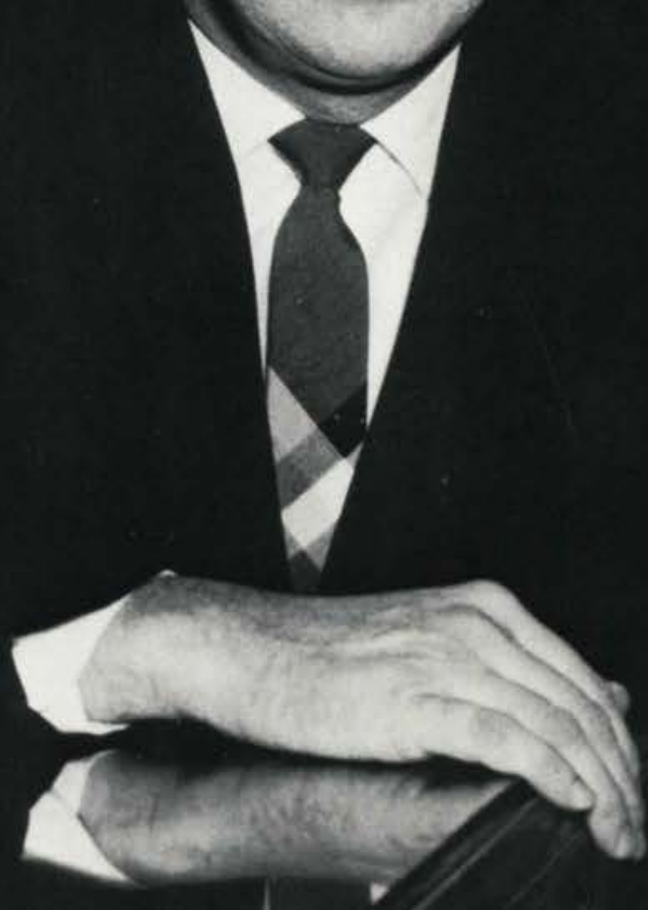




\section{PRESIDENT'S MESSAGE}

In the Scriptures light is symbolical of Deity. "God is light, and in him is no darkness at all." (I John 1:5). It is also used by the sacred writers to show man's need of a proper relation to God and response to Him. Light has been defined as the essential condition of vision; the opposite of darkness. Jesus taught this when he said, "I am the light of the world; he that followeth me shall not walk in darkness but shall have the light of life." (John 8:12). One who is "enlightened" has come to a place of spiritual illumination for the Psalmist said, "The entrance of thy words giveth light; it giveth understanding unto the simple." (Psalm 119:130). Since God is light we must be brought into proper relationship to Him by Christ, "The light of the world;" and then, instructed by His light-giving words, we may become conspicuous for Christ as "lights in the world." It is our prayer that every graduate of Cedarville College shall thus "walk as children of light."

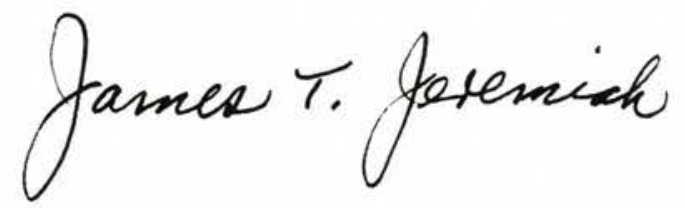

George S. Milner Chairman

George L. Boyd William A. Brock James T. Jeremiah C. R. Maddox
William B. Peterson Robert M. Underwood Earl V. Willetts Arthur F. Williams W. Thomas Younger

\section{BOARD OF TRUSTEES} CEDARVILLE COLLEGE

Mr. Charles Barth

Rev. George A. Bates

Rev. William Brock

Mr. George L. Boyd

Mr. Norman B. Chappell

Rev. Alfred Colwell

Rev. Glenn Davis

Mr. John A. Draxler

Mr. Arthur Dyke

Mr. Herman W. Harvey

Rev. James T. Jeremiah

Mr. George S. Milner
Rev. Kenneth A. Muck Mr. J. Dale Murphy Mr. E. A. Morton Mr. William B. Patterson

Rev. Wilbur C. Rook Rev. Gerald Smelser Mr. Eugene B. Smith Mr. Charles Wallace Rev. Earl V. Willetts

Rev. Donald Woodby.

Rev. Thomas Younger Dr. Fred Milkie, $P b . D$. 

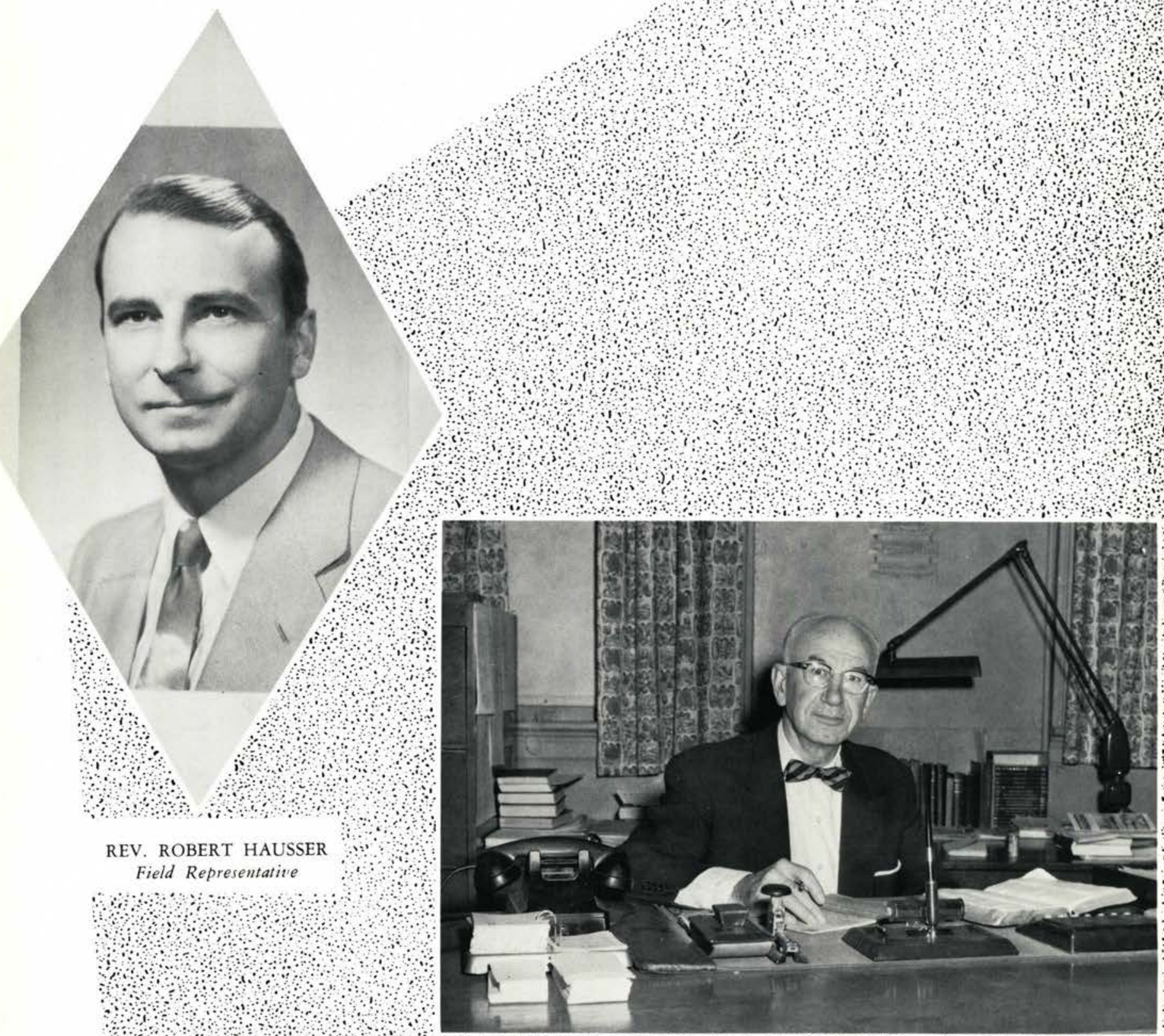

DR. ARTHUR WILLIAMS, Dean of Students

REV. ROBERT HAUSSER Field Representative

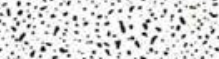
$4+$ ind 


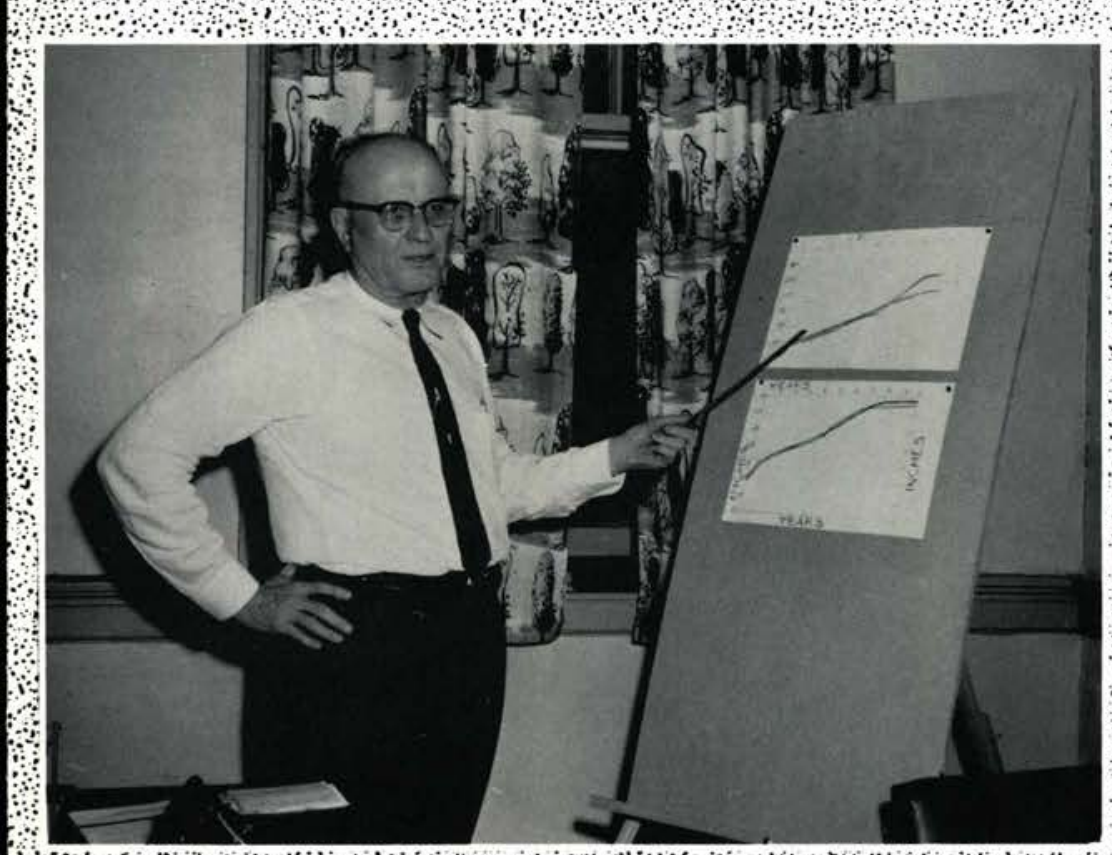

DR. CLIFFORD R. MADDOX, Academic Dean

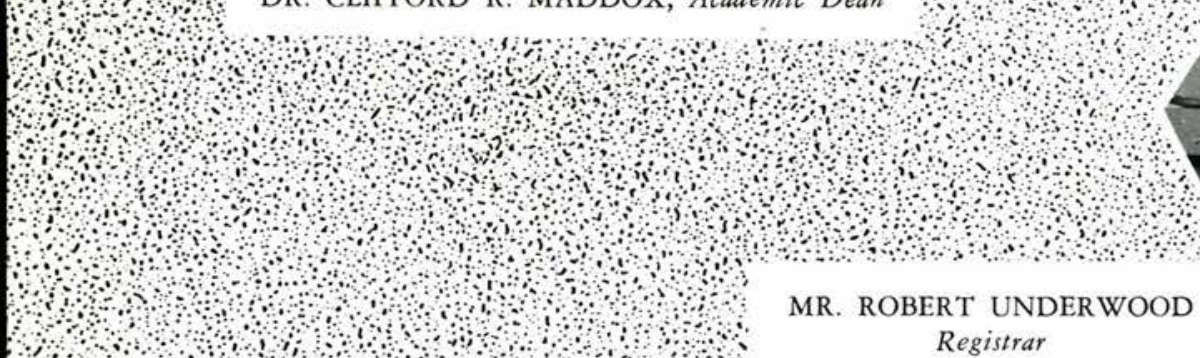
Registrar

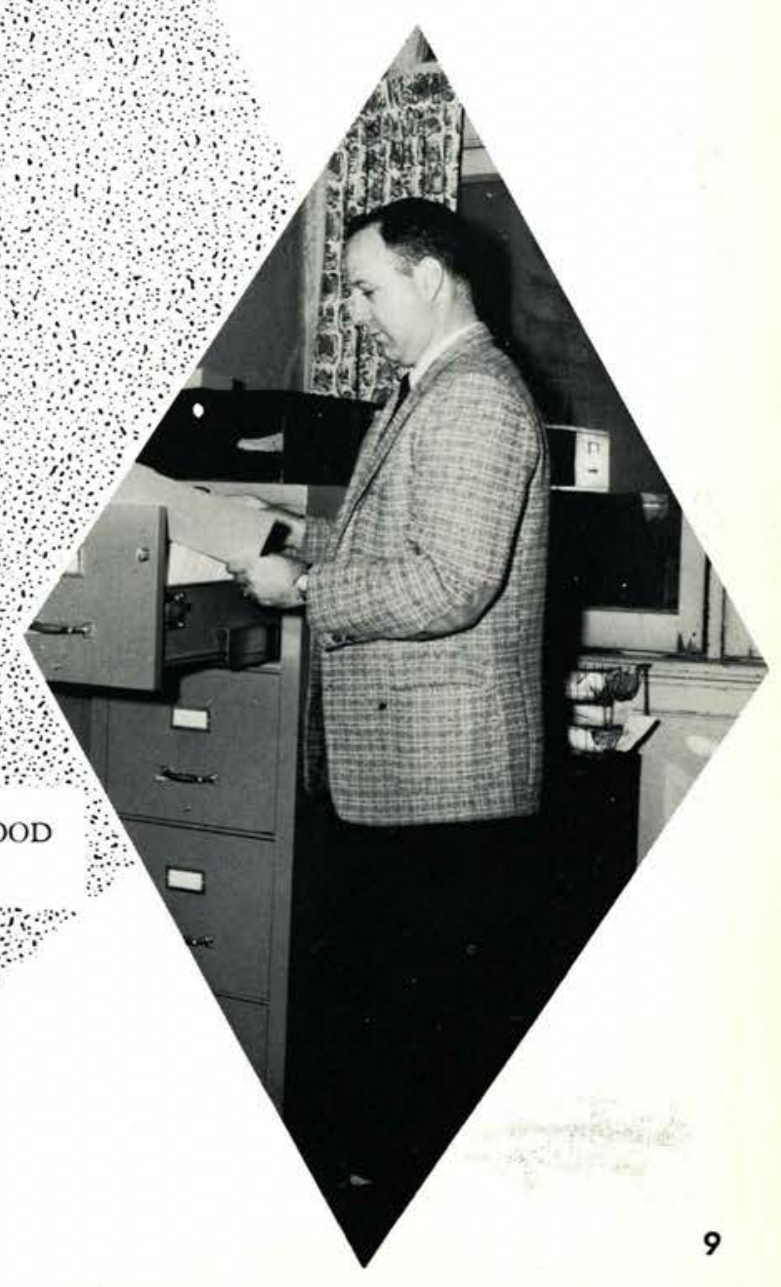




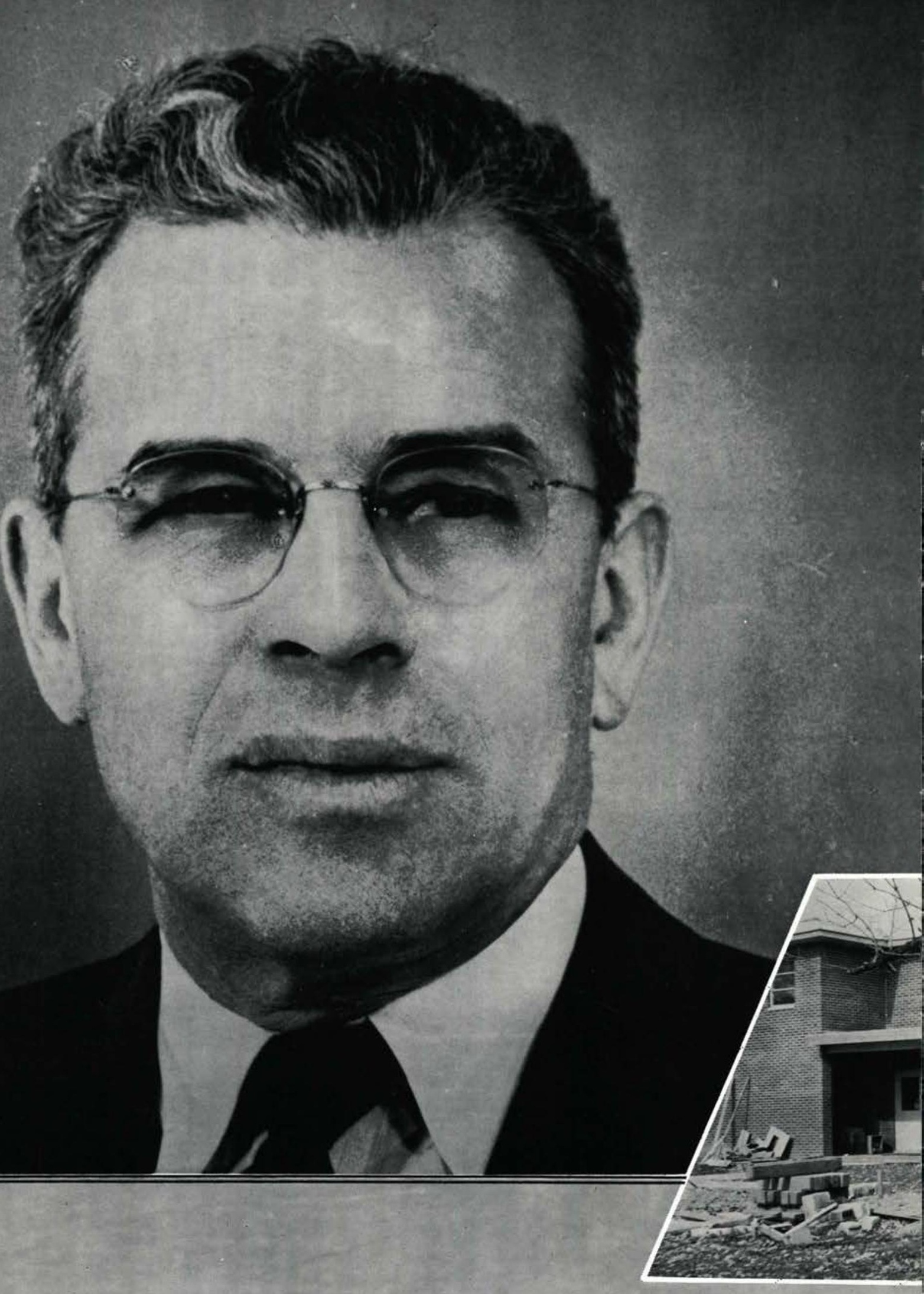




\section{Dedication}

Individual interest is a motivating force used of God for progress and development here at Cedarville College. The operational picture of the college would not be complete without consideration of those who have labored unassumingly to honor the Lord and be of aid to the college with the gift of time and ability.

As an active member of the Board of Trustees, W. B. Patterson has also been personally responsible for the electrification, rewiring and maintenance of the electrical systems throughout the various buildings of the college.

We, the Junior Class, desire to express sincere thanks to Mr. Patterson for his labor and interest in the college. 


\section{Progress}

At

\section{Cedarville}

With the anticipation last spring of an increased student body, construction was begun in May to enlarge and improve the dining hall and chapel. Even as the shadows of the roof beams fell on the new brick siding ...
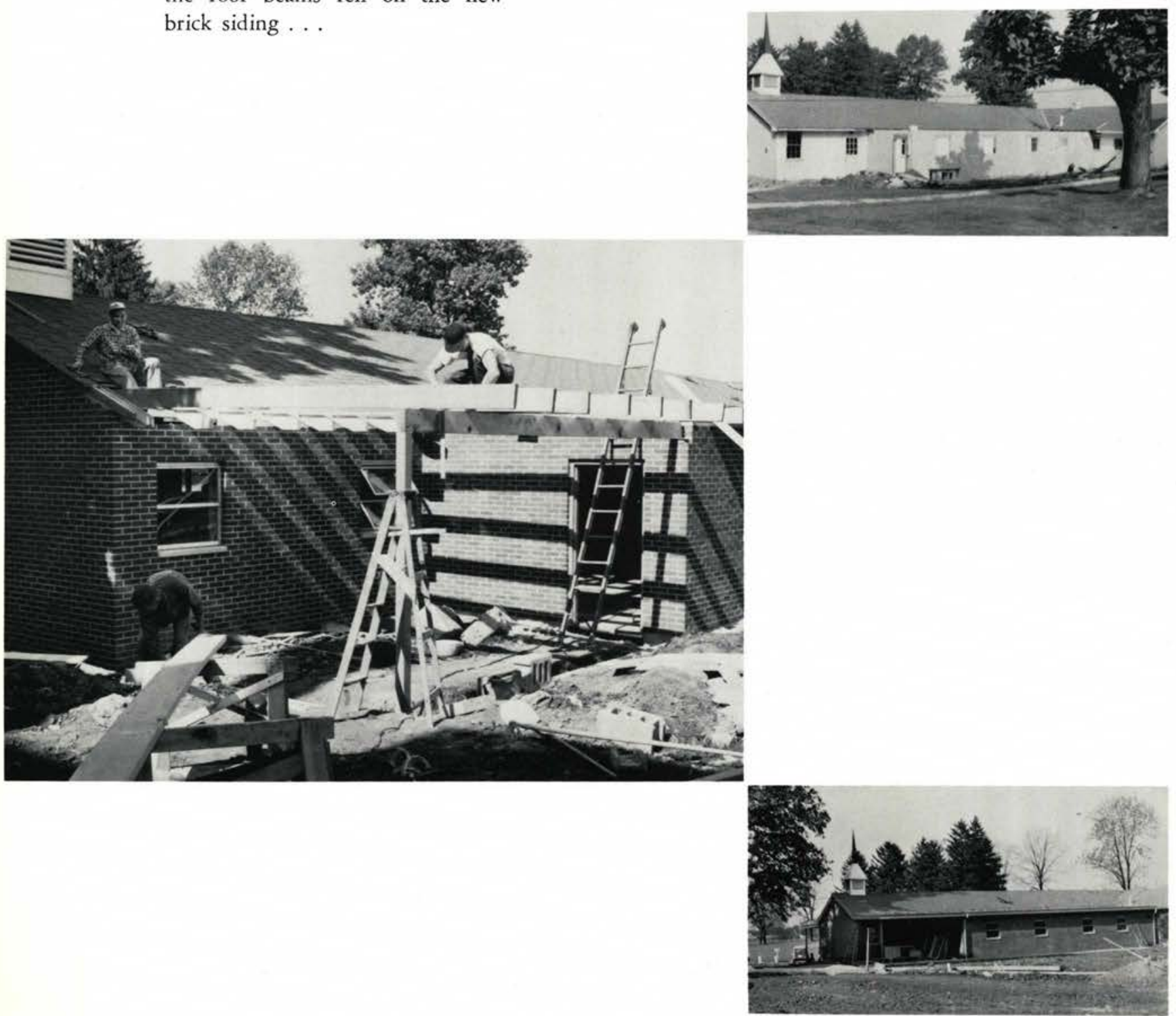


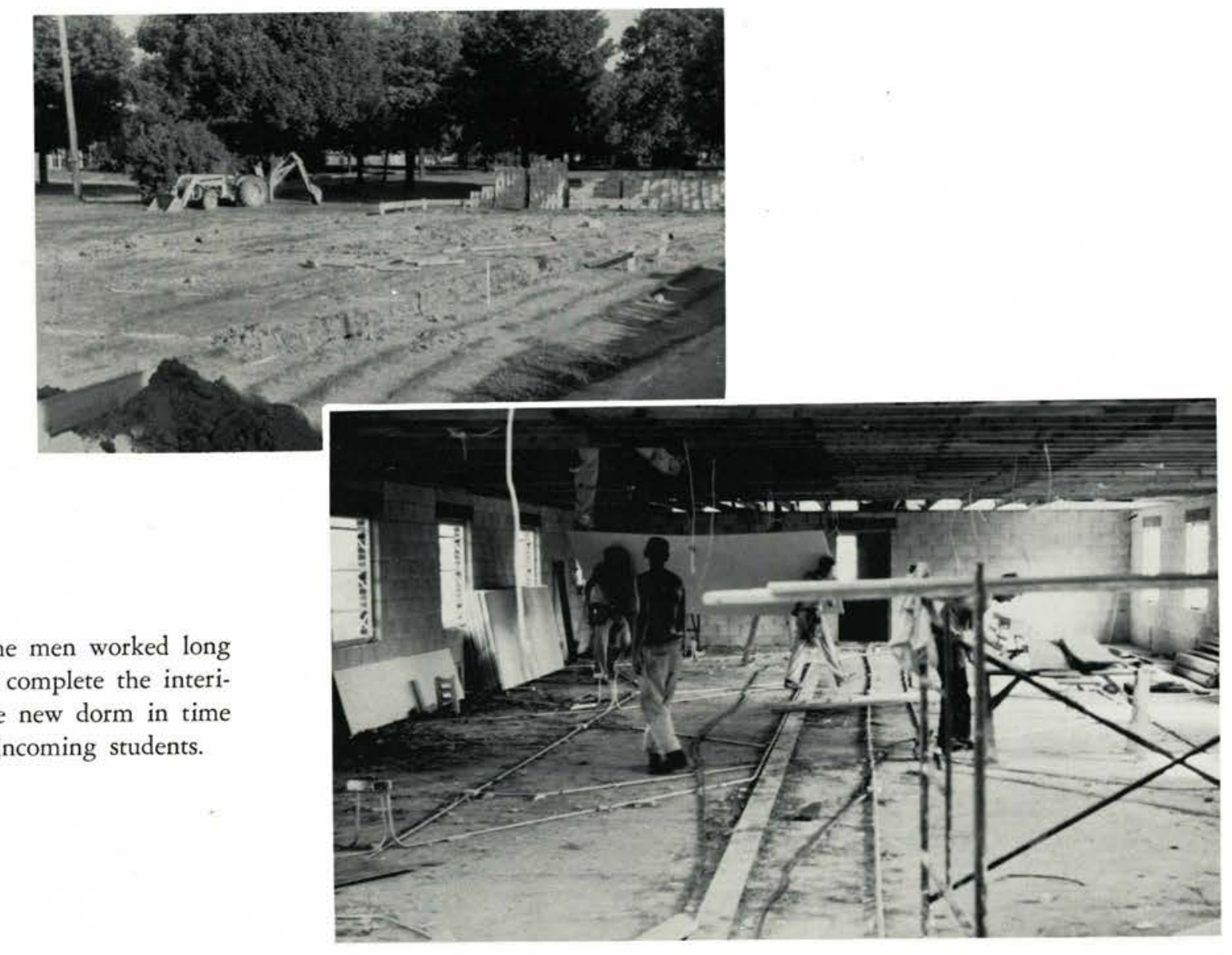
hours to complete the interior of the new dorm in time for the incoming students.

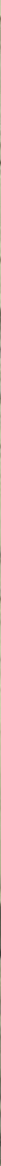


the Lord hath showed us light

Faculty

Staff 


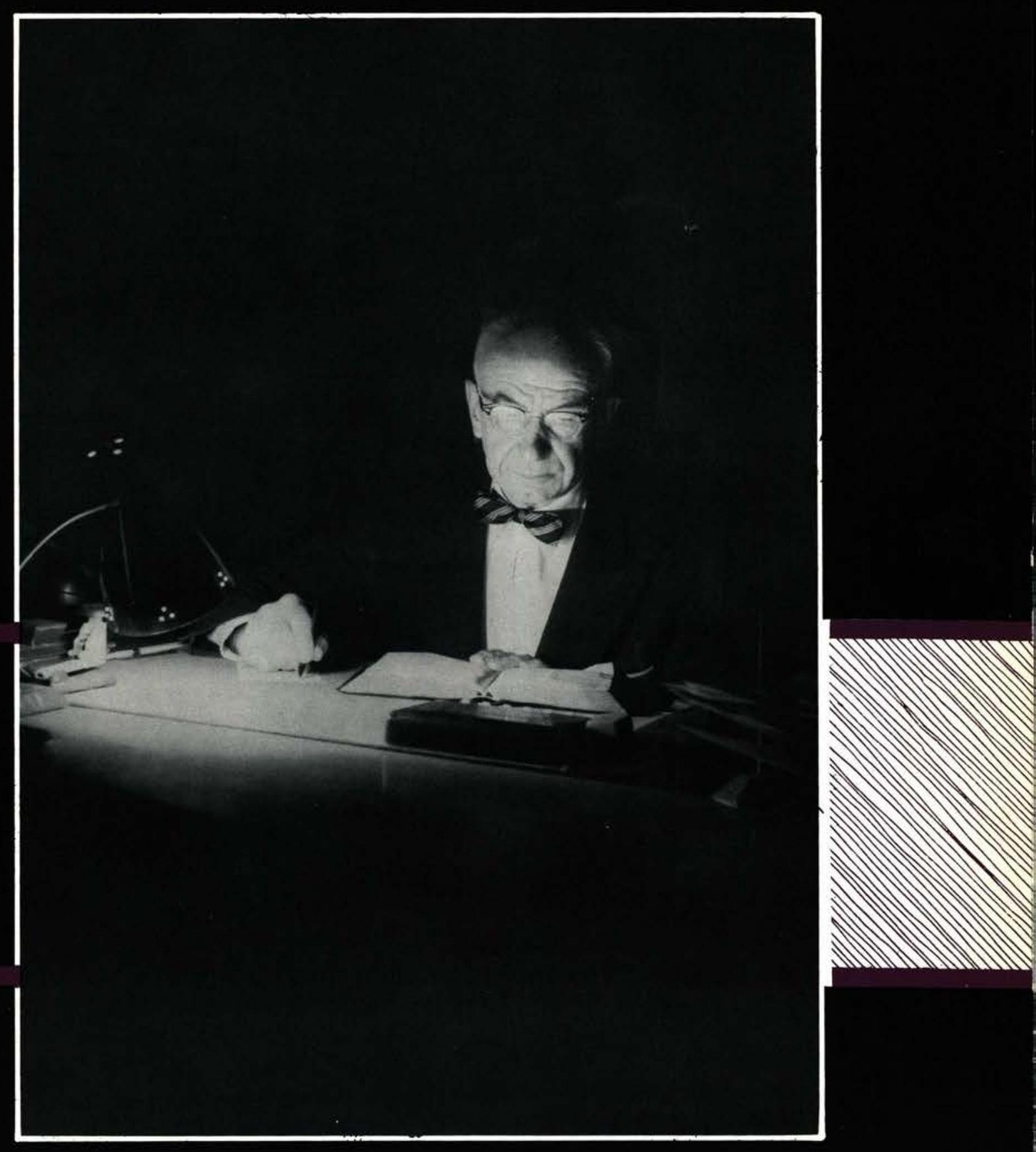



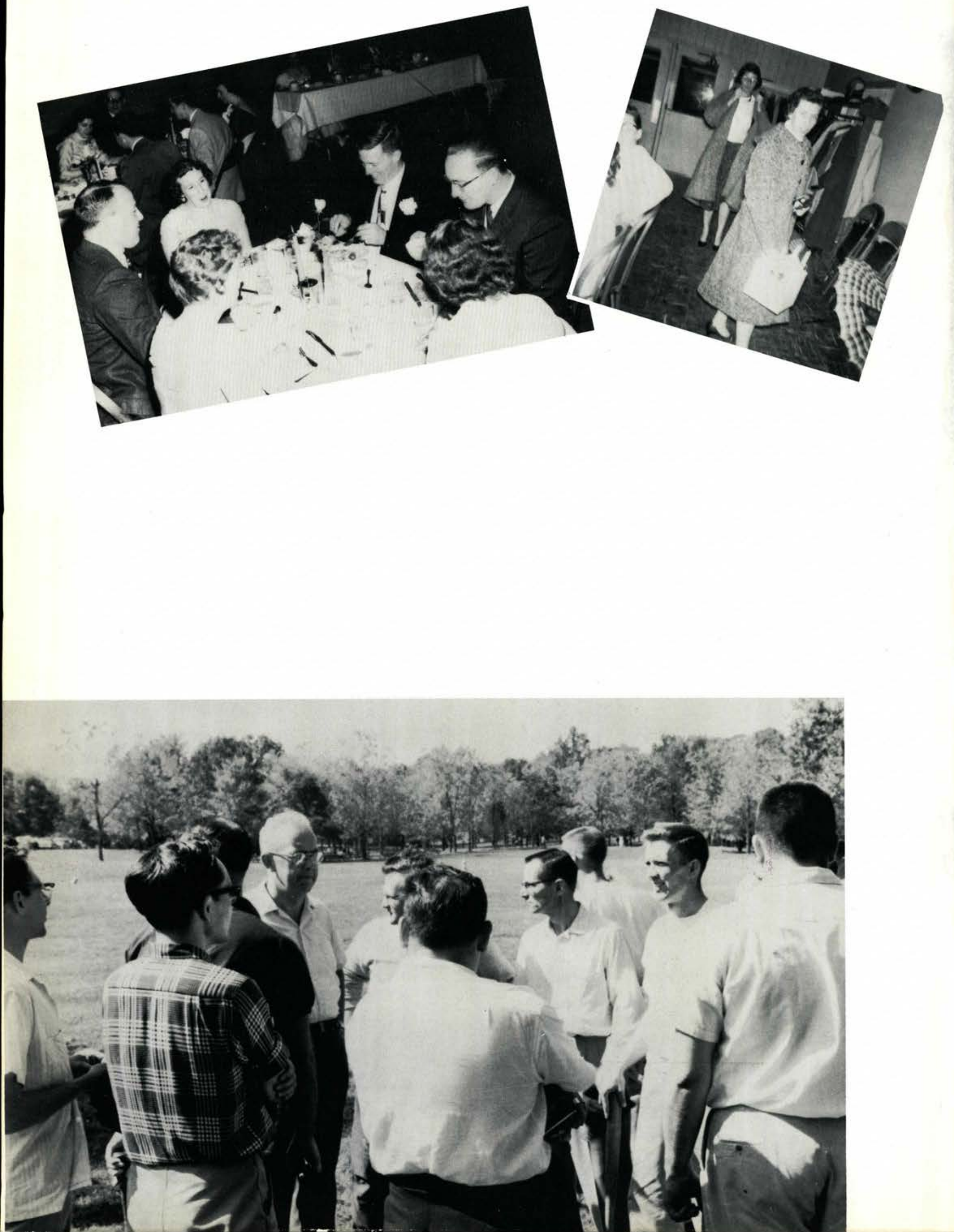

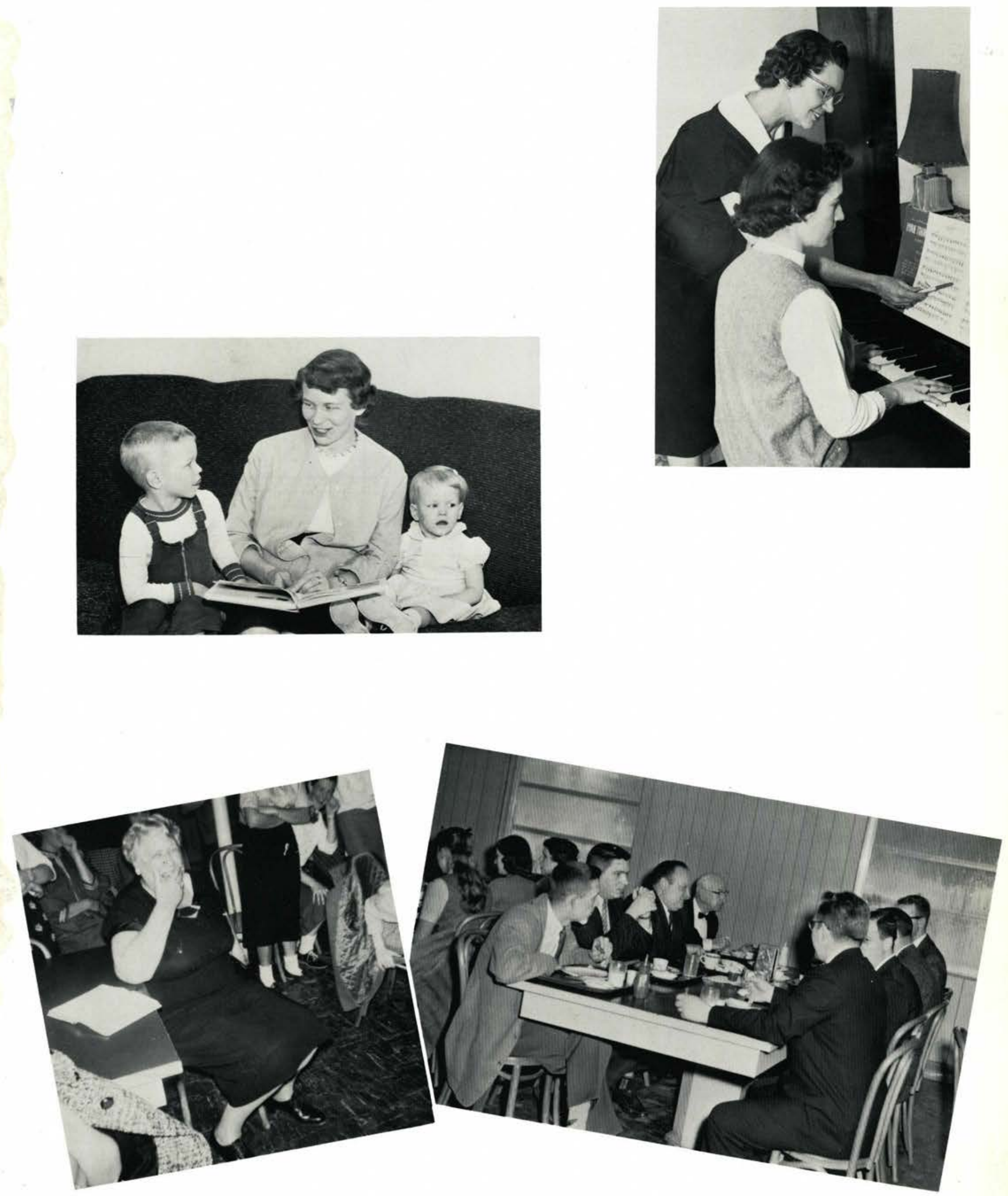

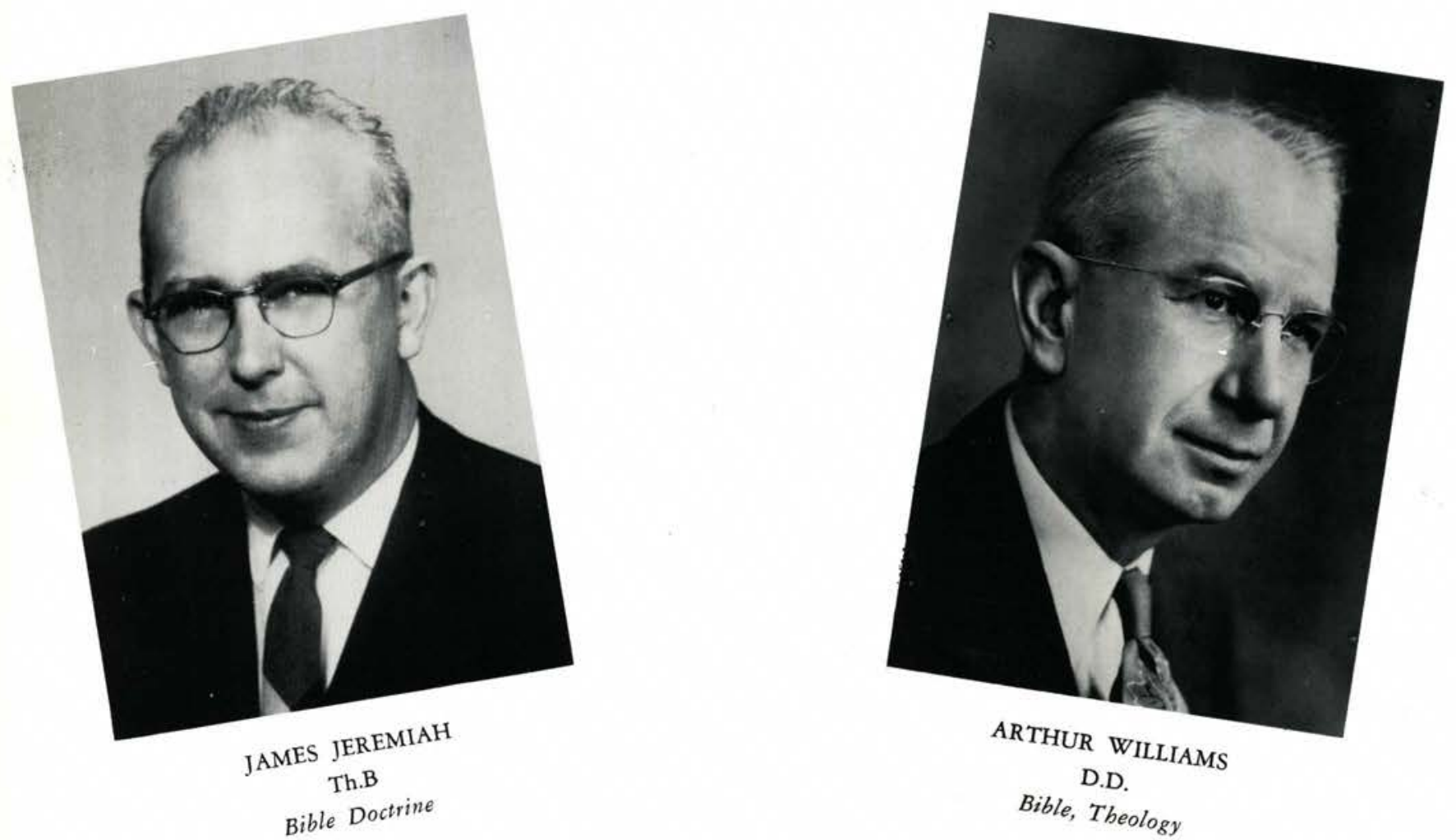

Bible, Theology

\section{Bible}
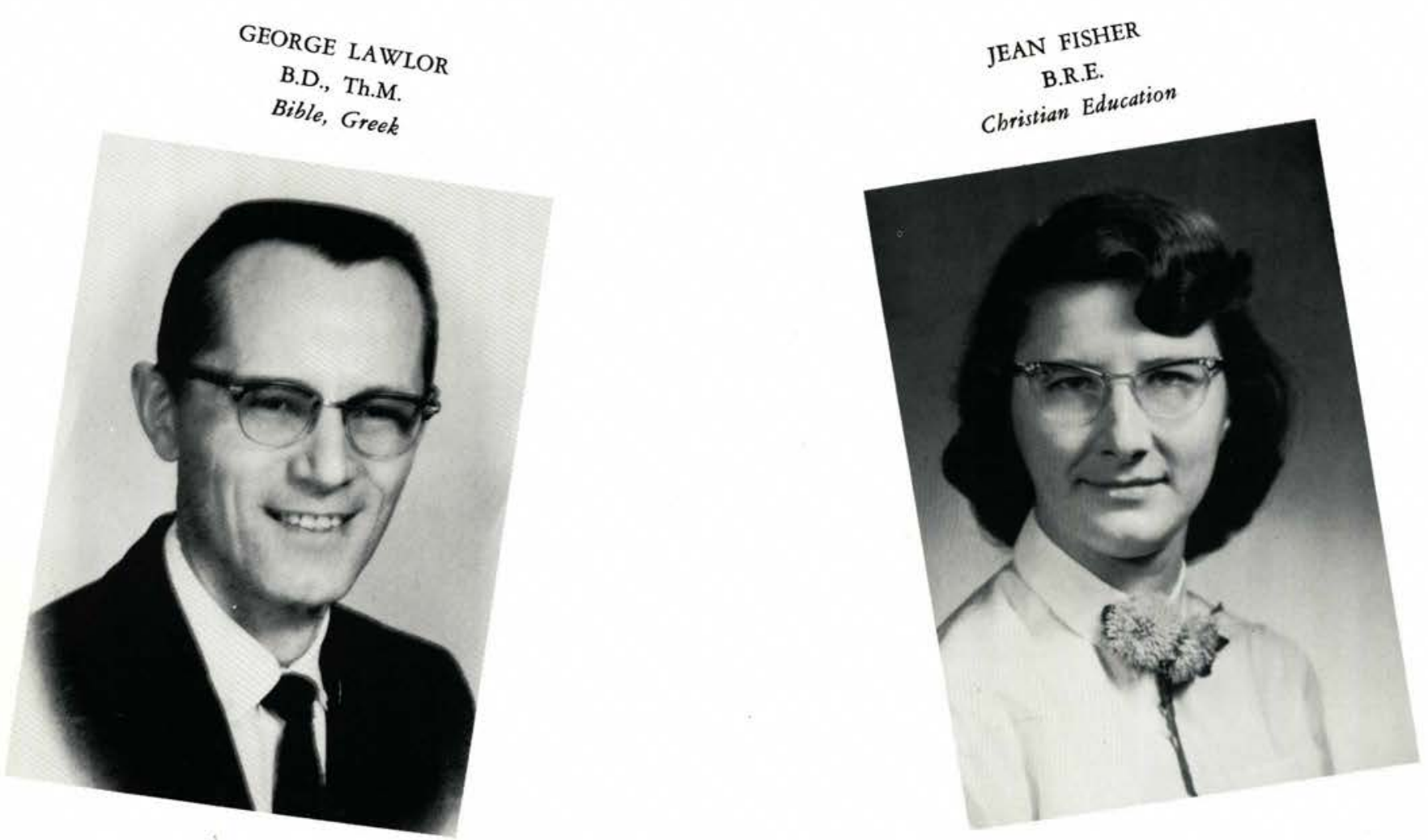

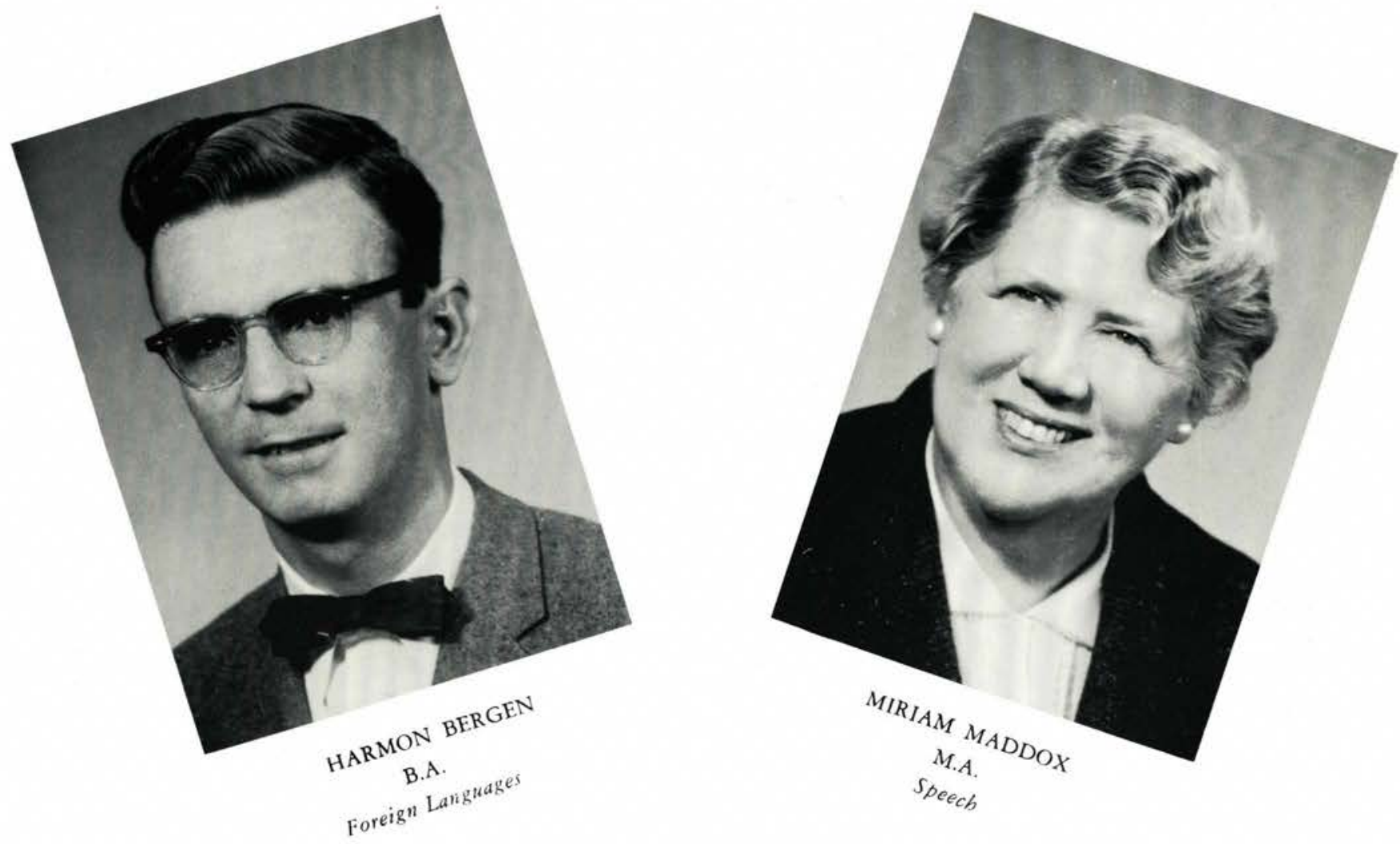

\section{Language and Literature}
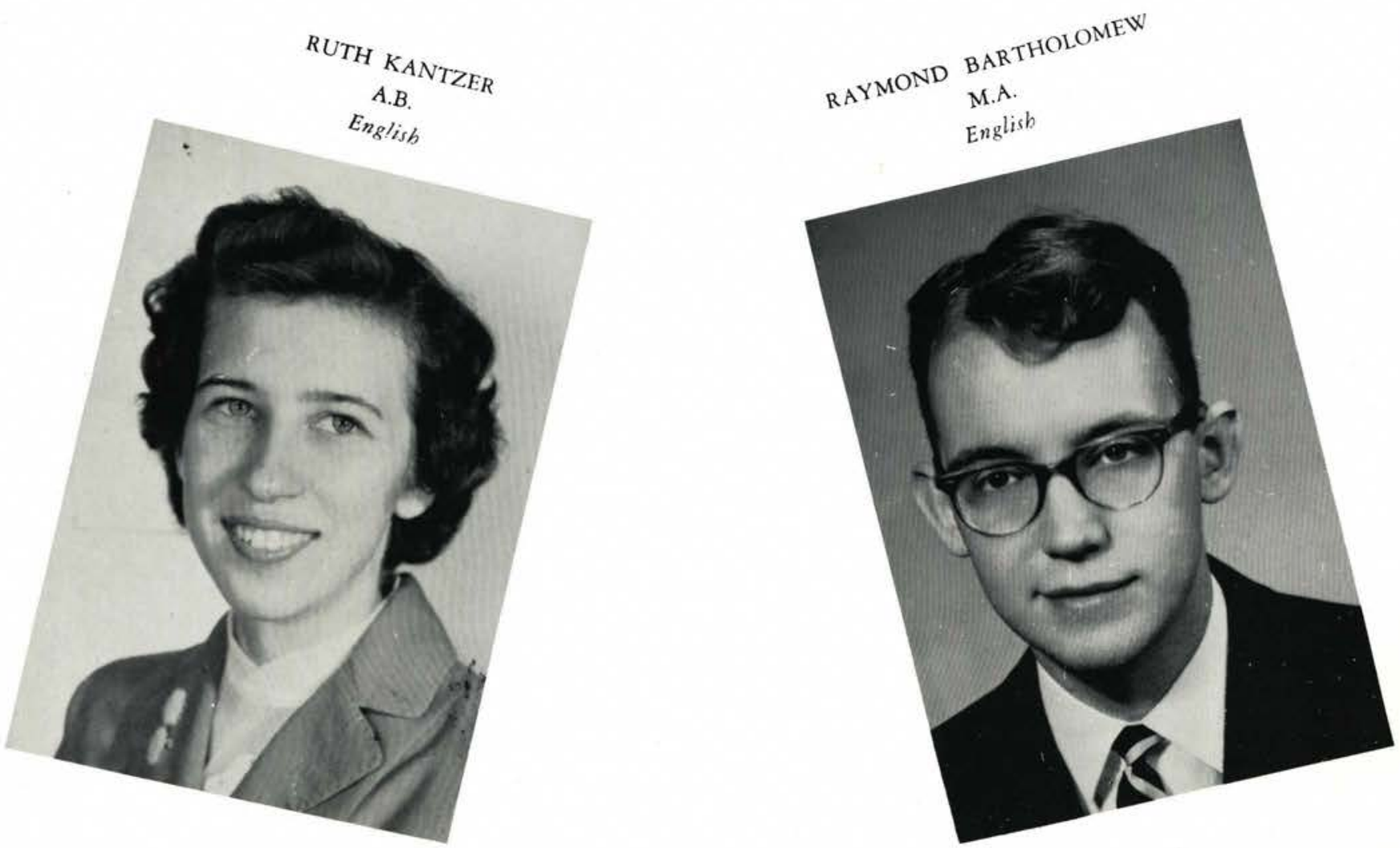

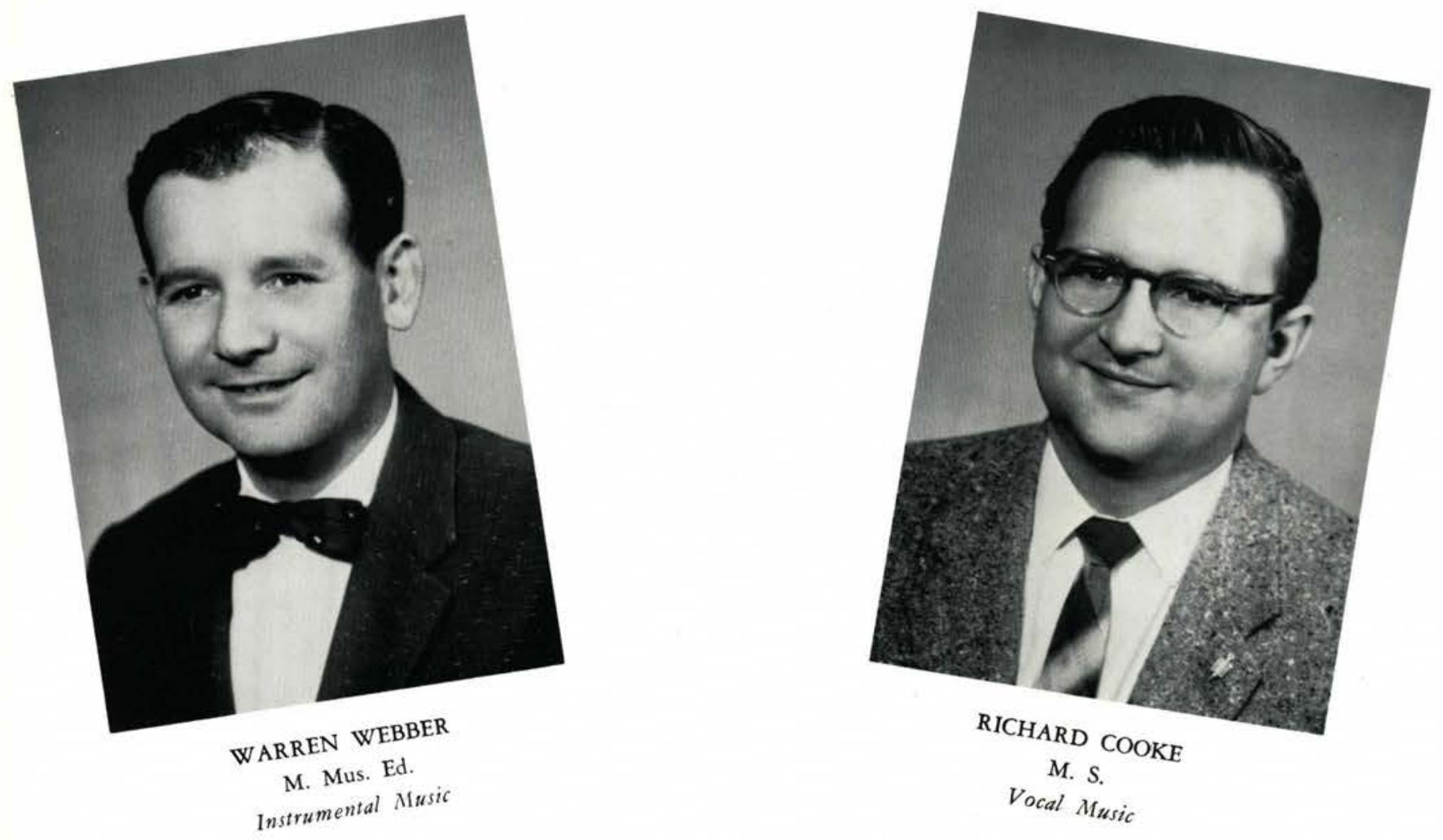

\section{Music}
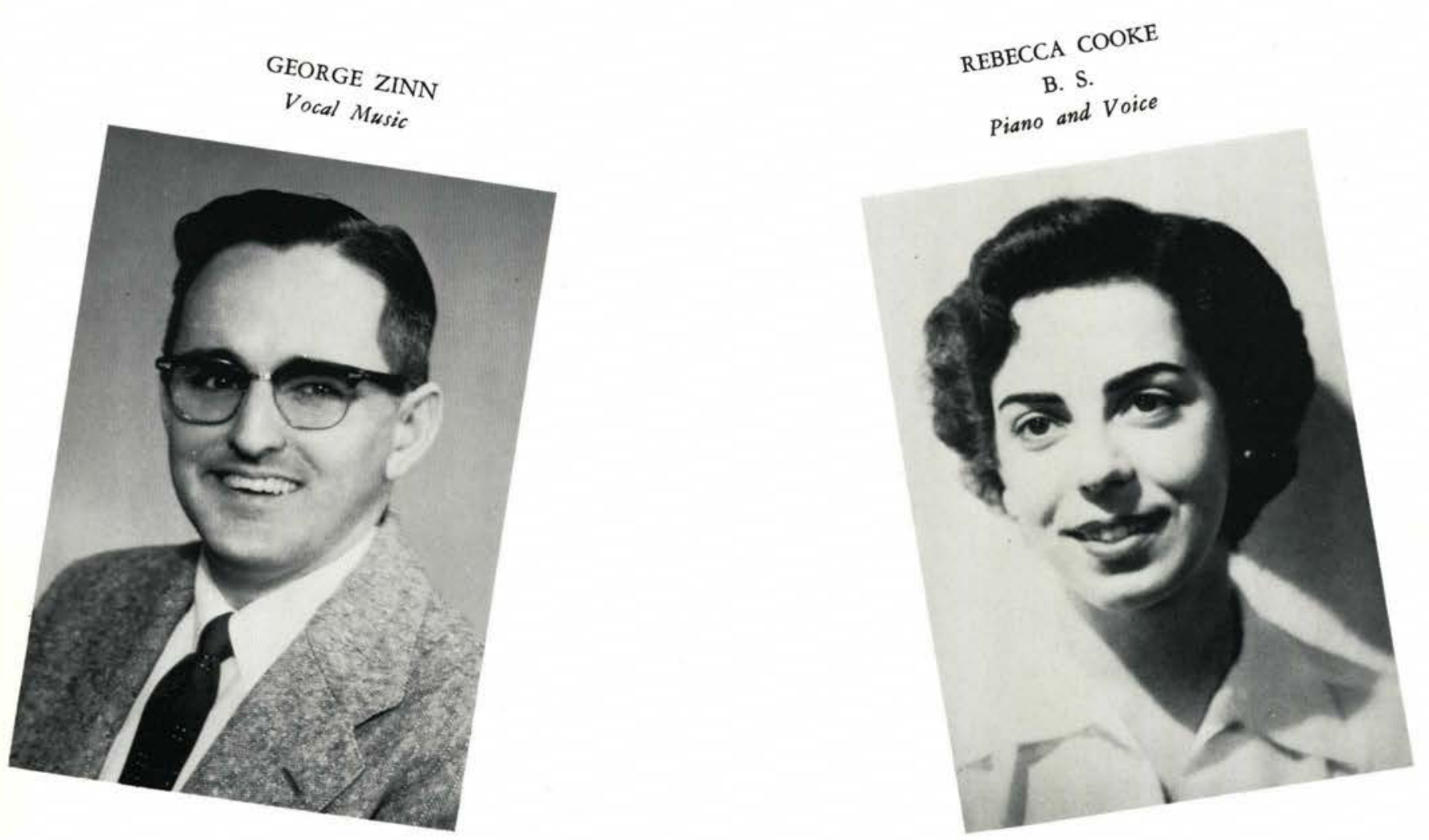


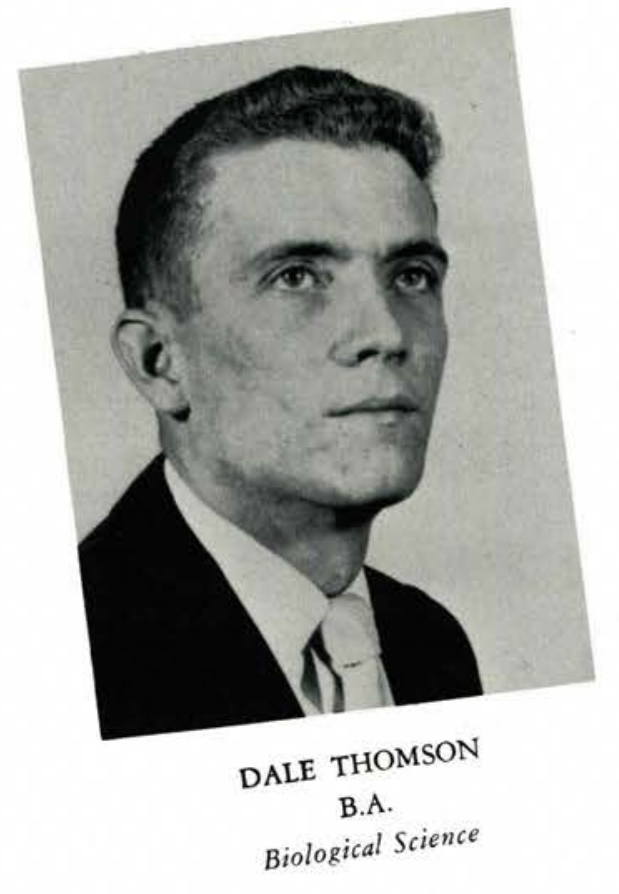

\section{Science}

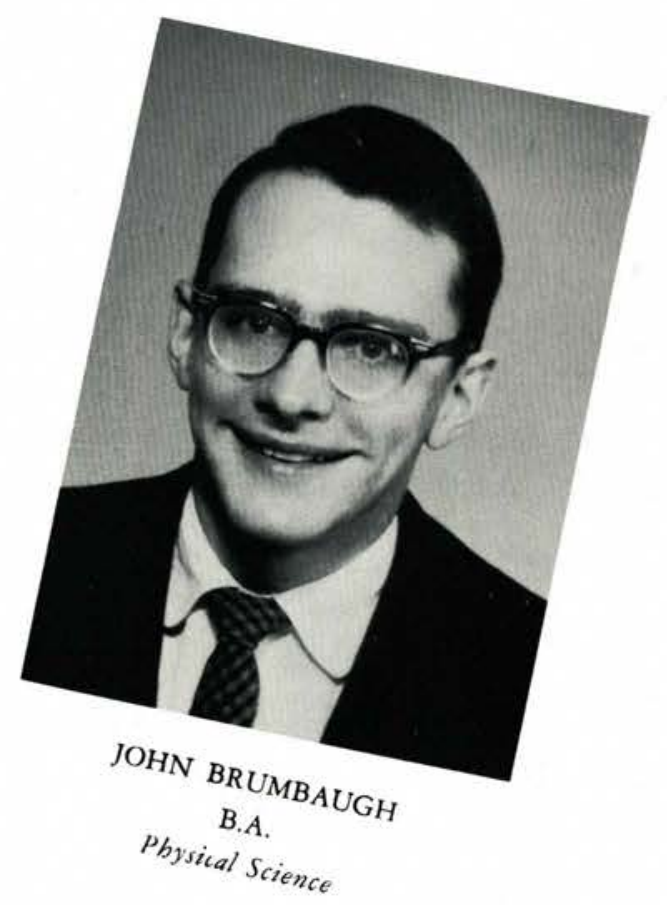

Education and Psychology

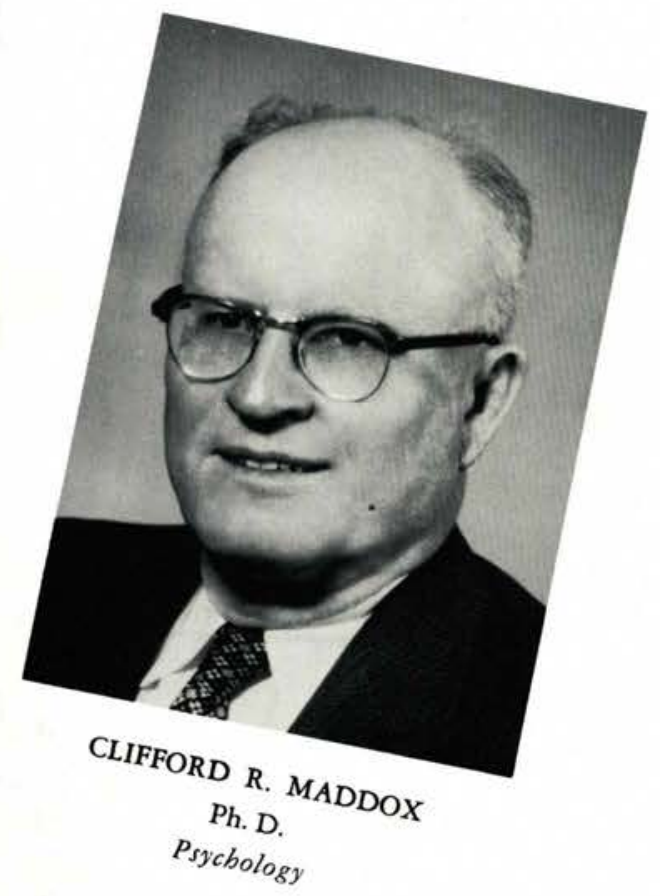

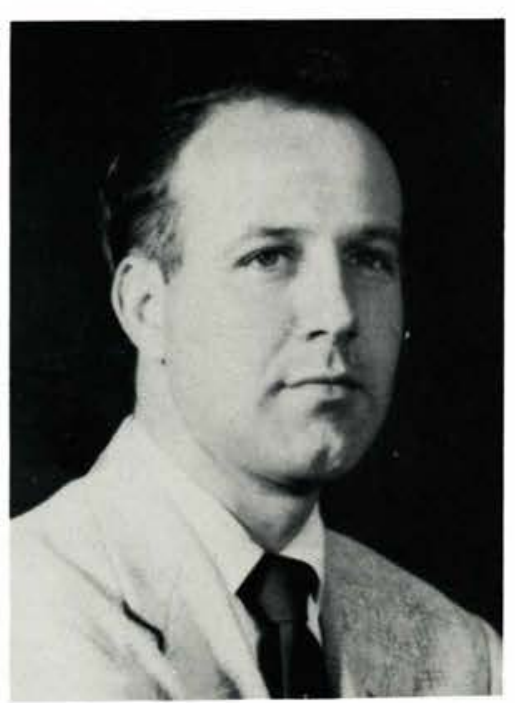

ROBERT UNDERWOOD

M.A.

Education

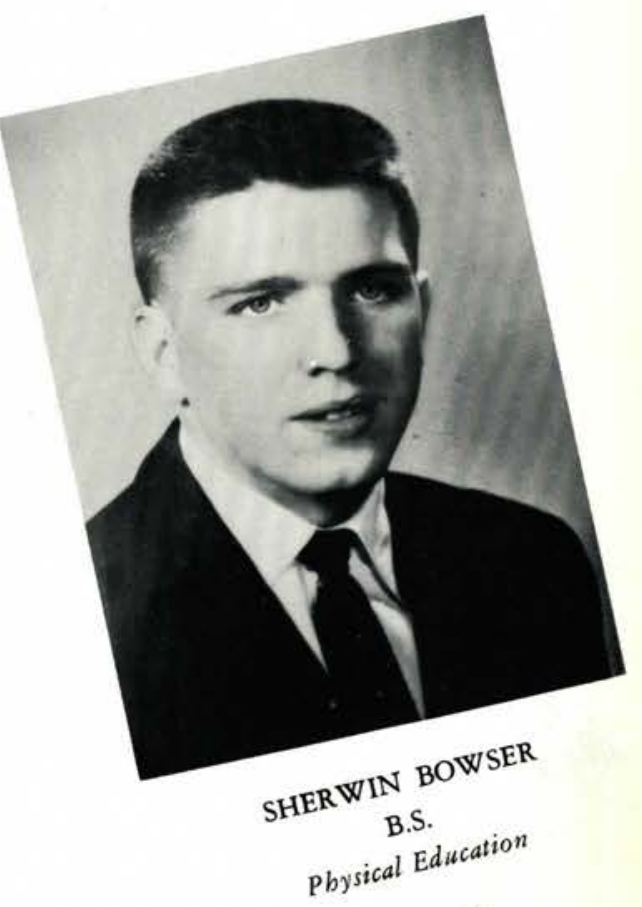



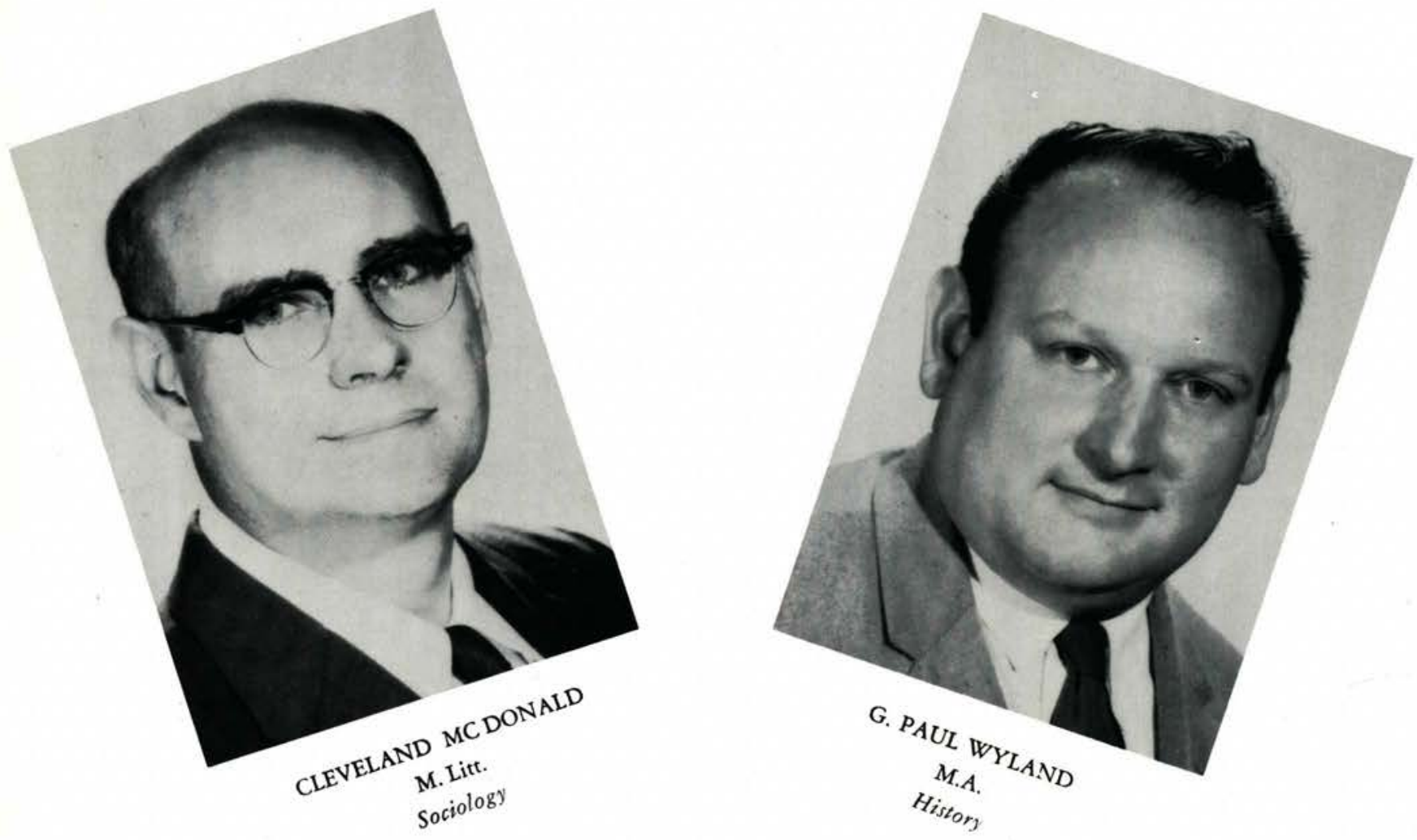

\section{Social Science}
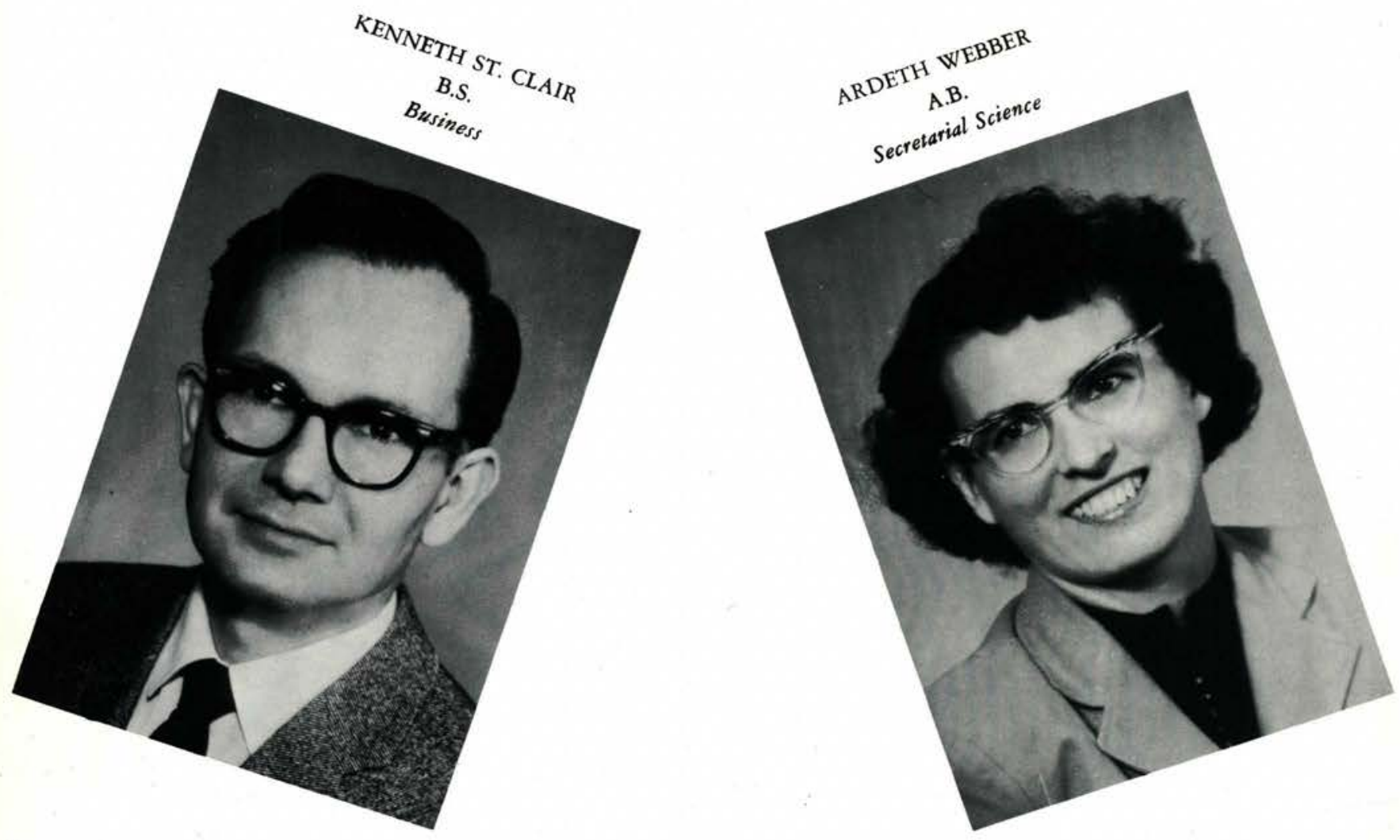



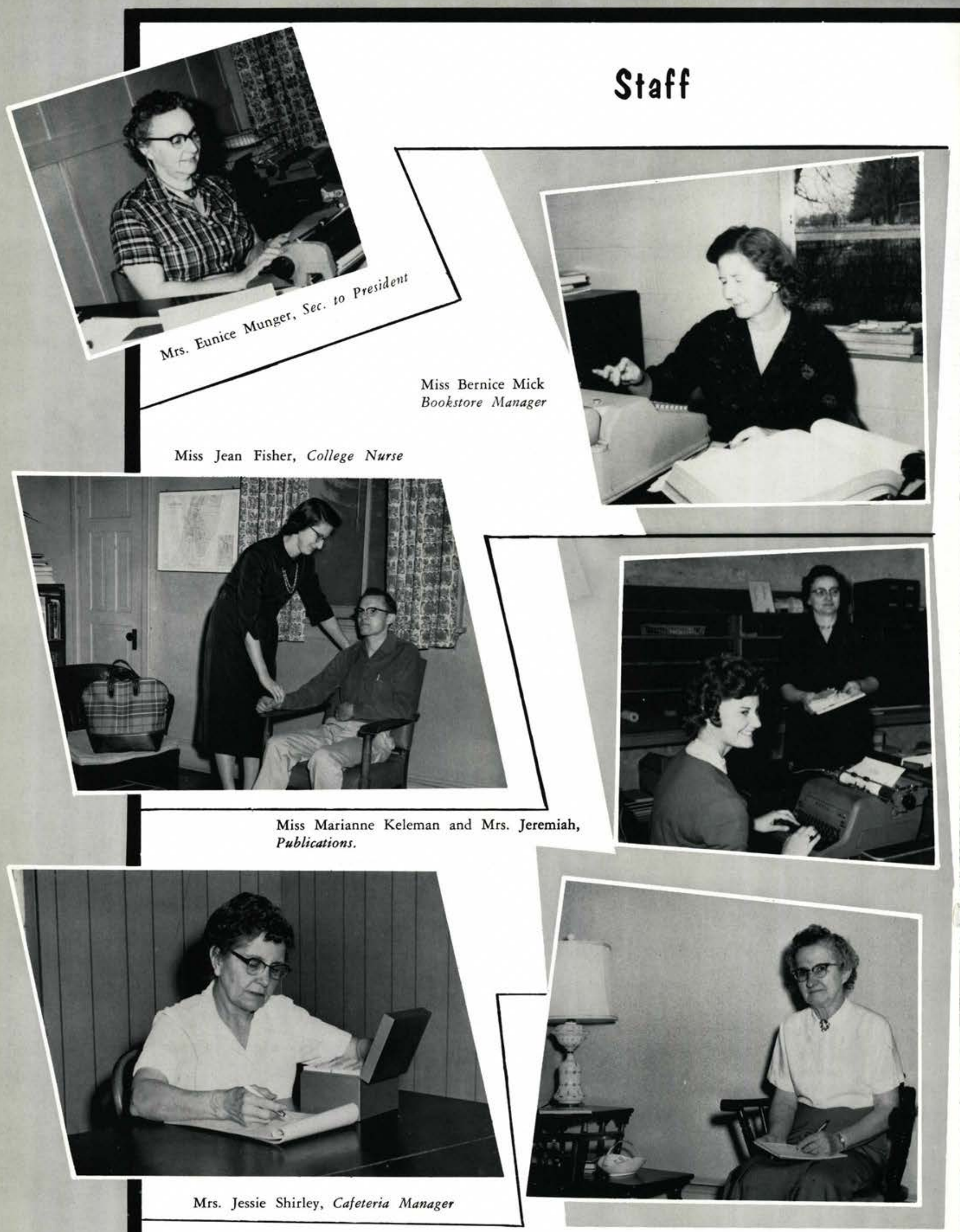

Mrs. Ruth Underwood, Dorm Mother 


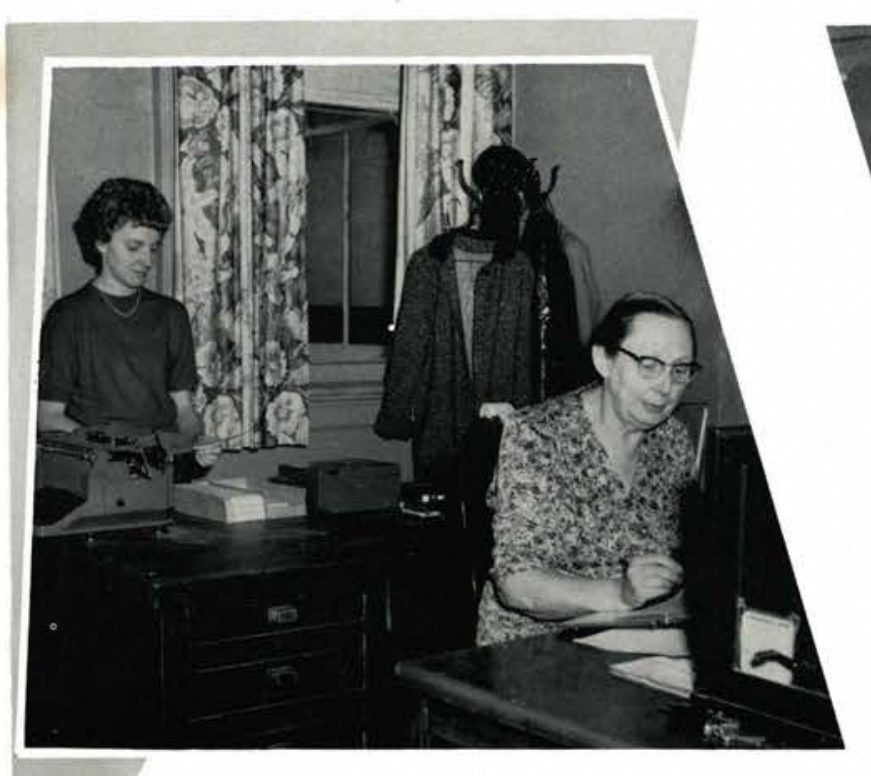

Miss Elinor Keefer, Bookkeeper; Mrs. Esther Ruder, Cashier.

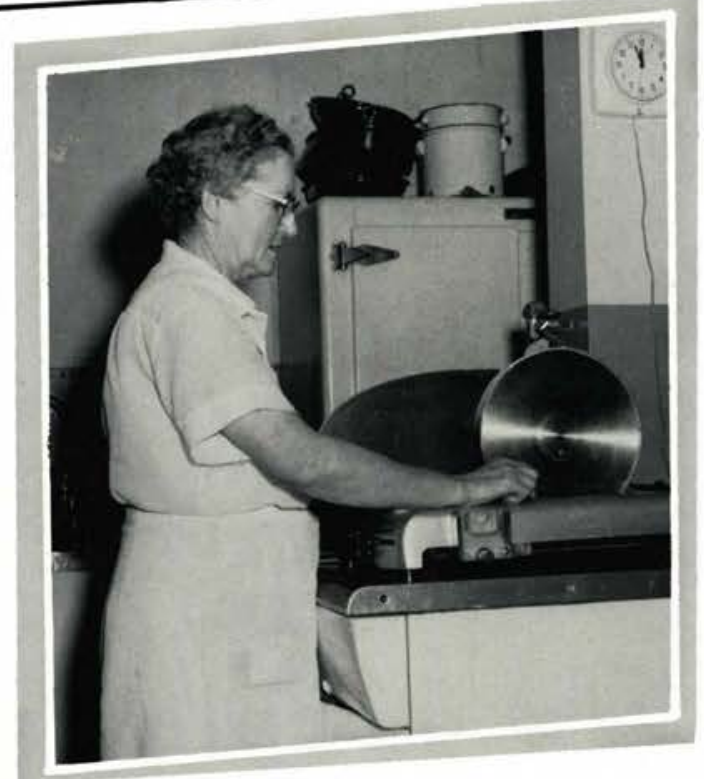

Mrs. Vida Friberg, Cafeteria Assistant

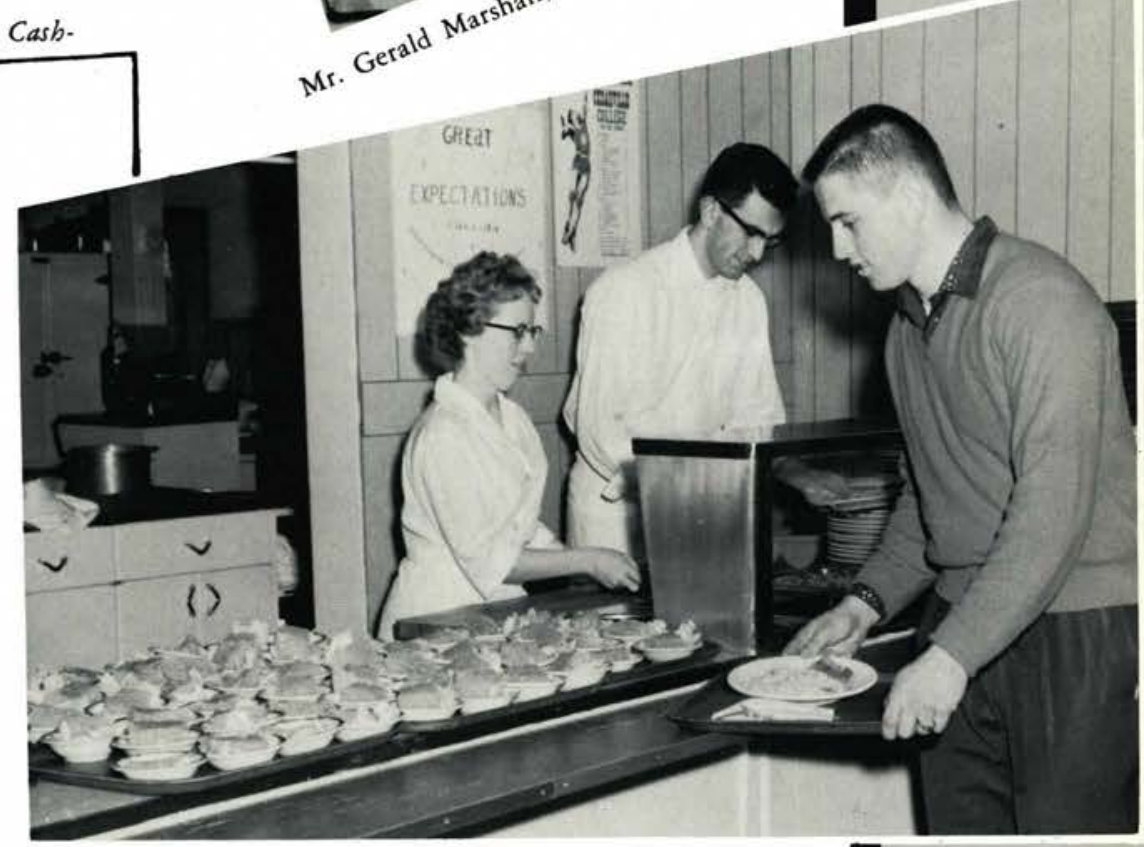

Mr. Norm Getty, Cook; Phyllis Dobbs, Student Assistant
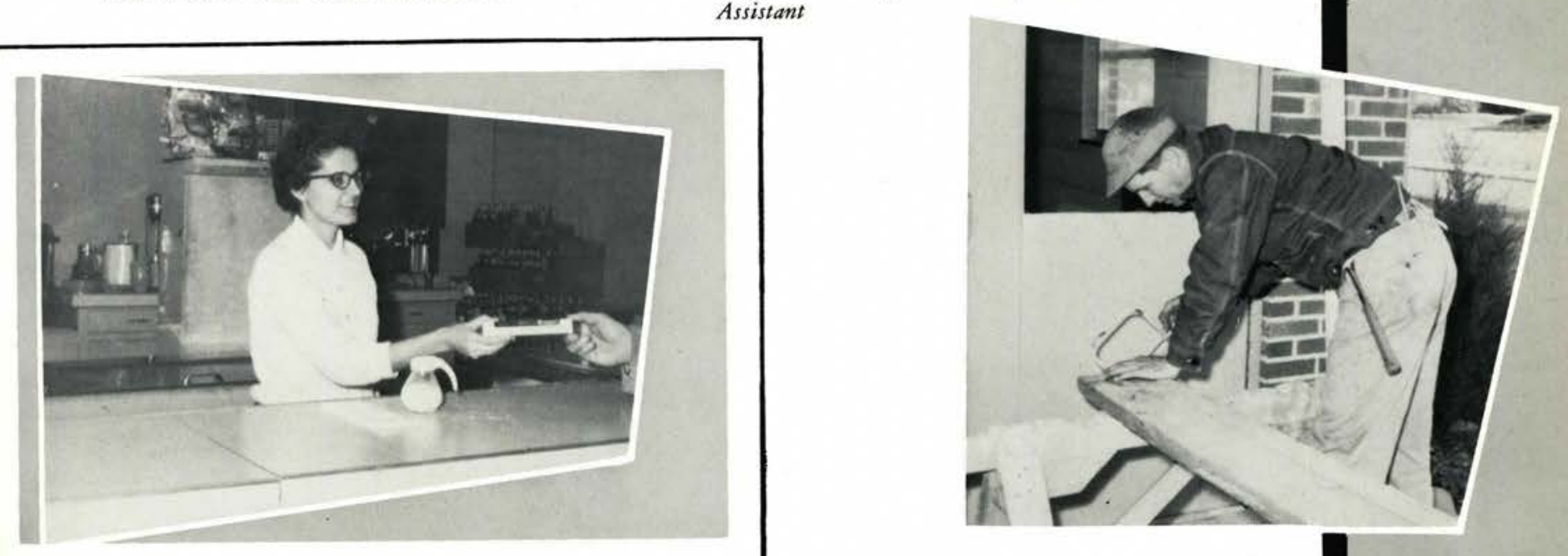
the Lord is my bigh tower. . . He is acquainted with all my ways.

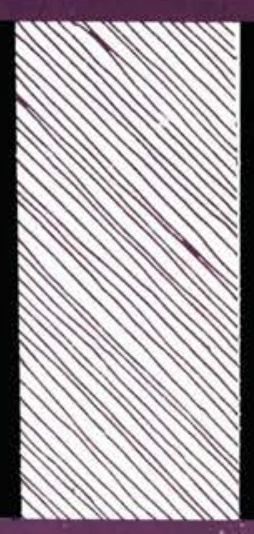

Activities 


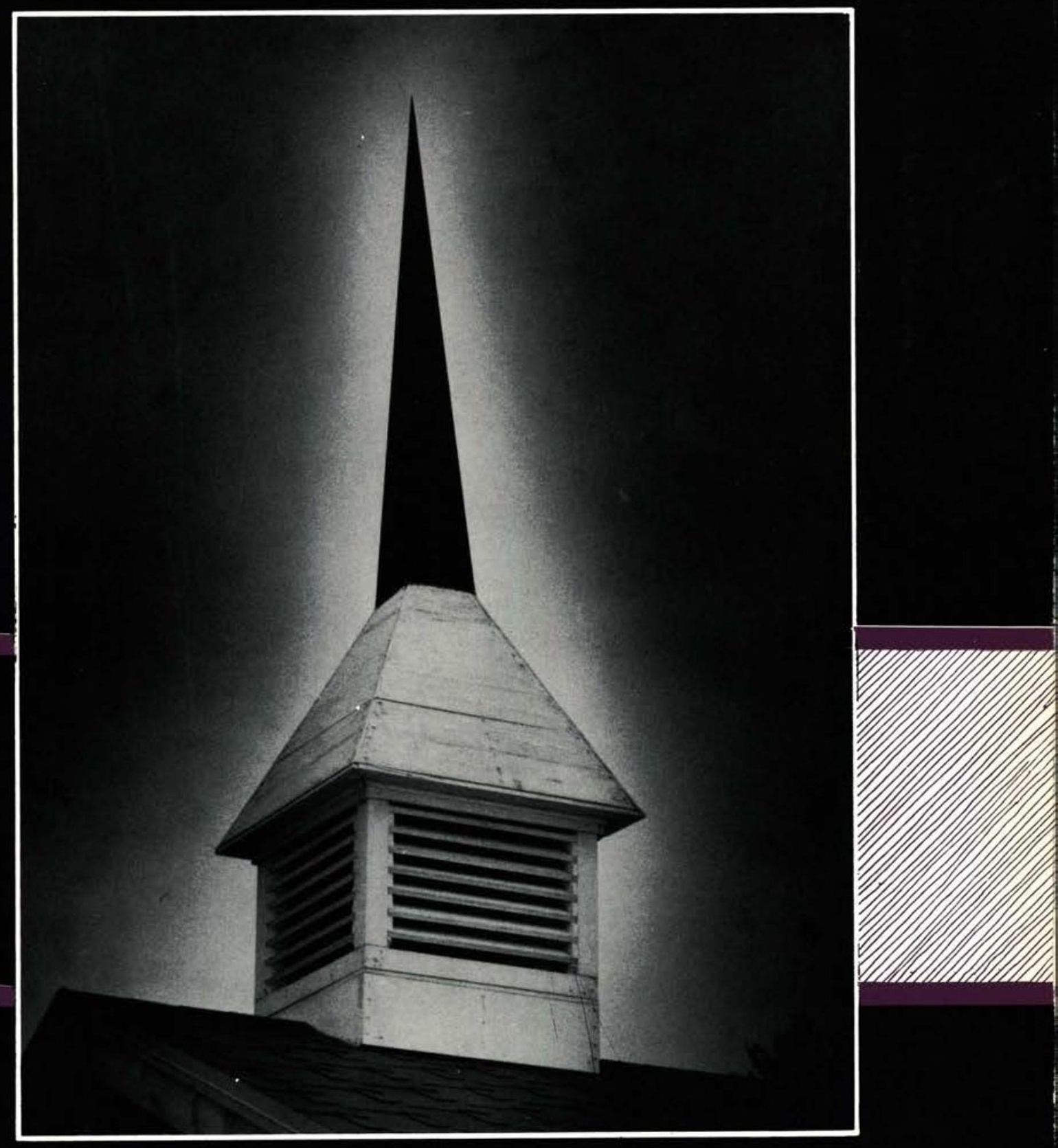




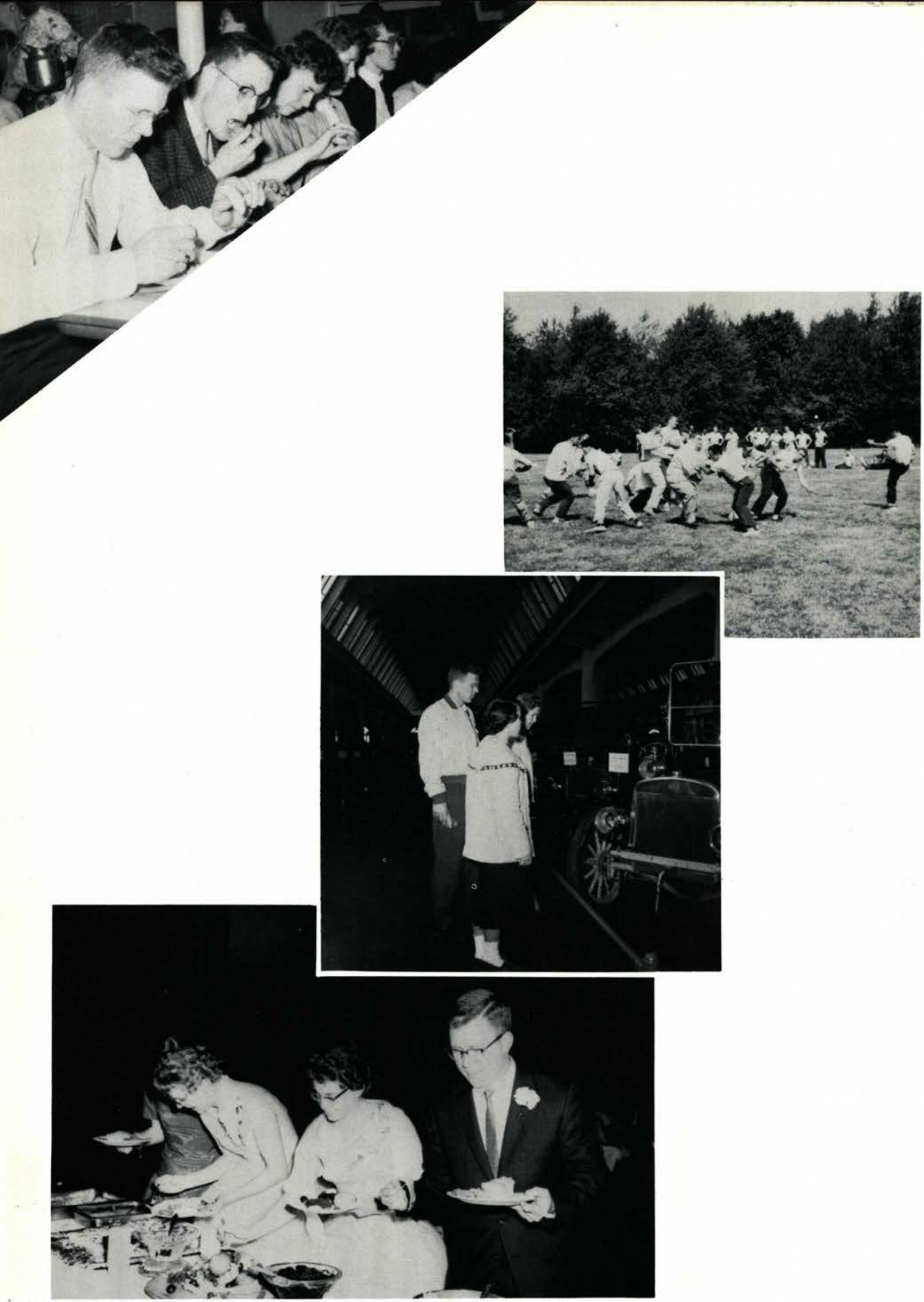




\section{Organizations}

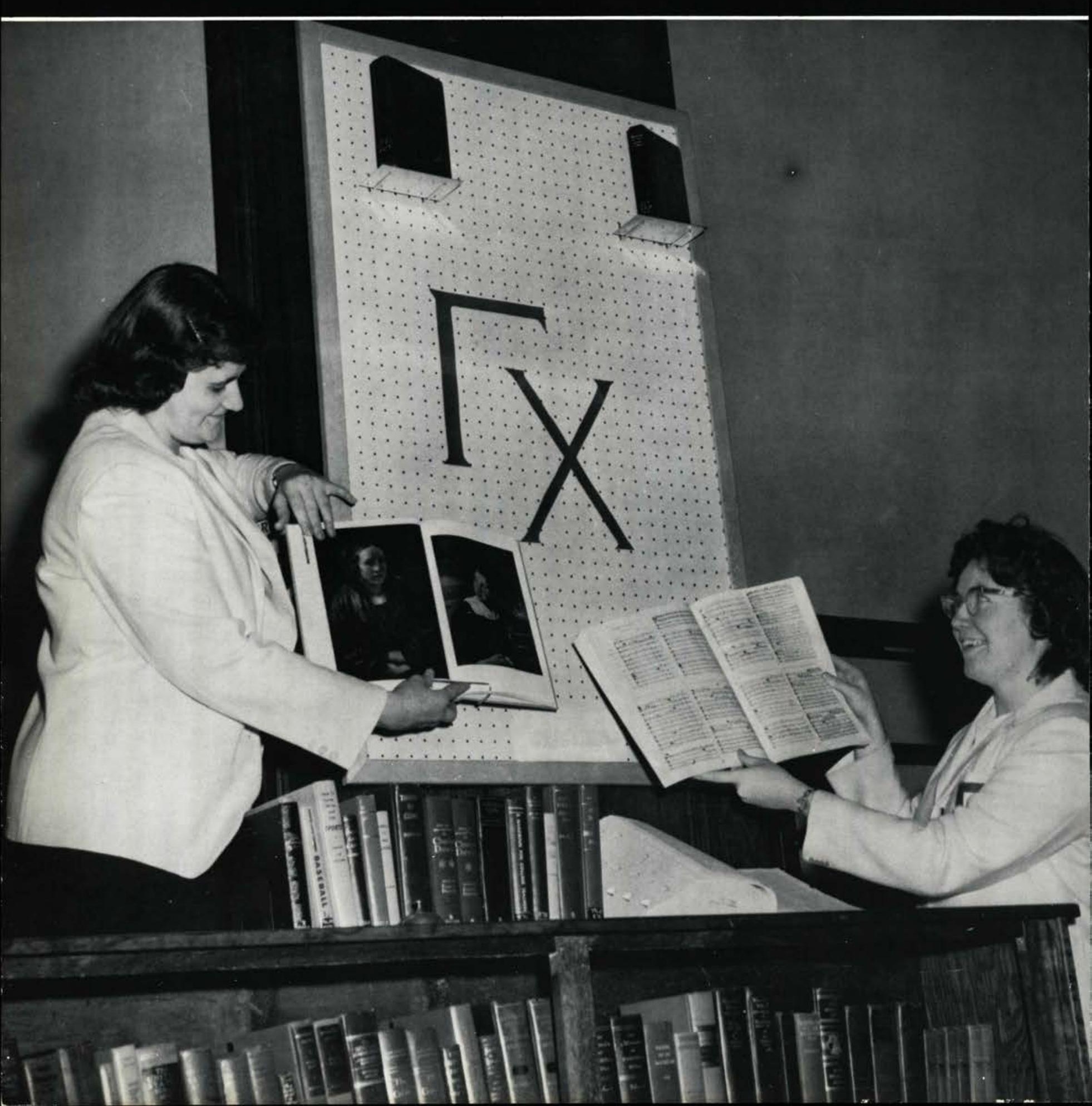




\section{Fellowship For World Missions}

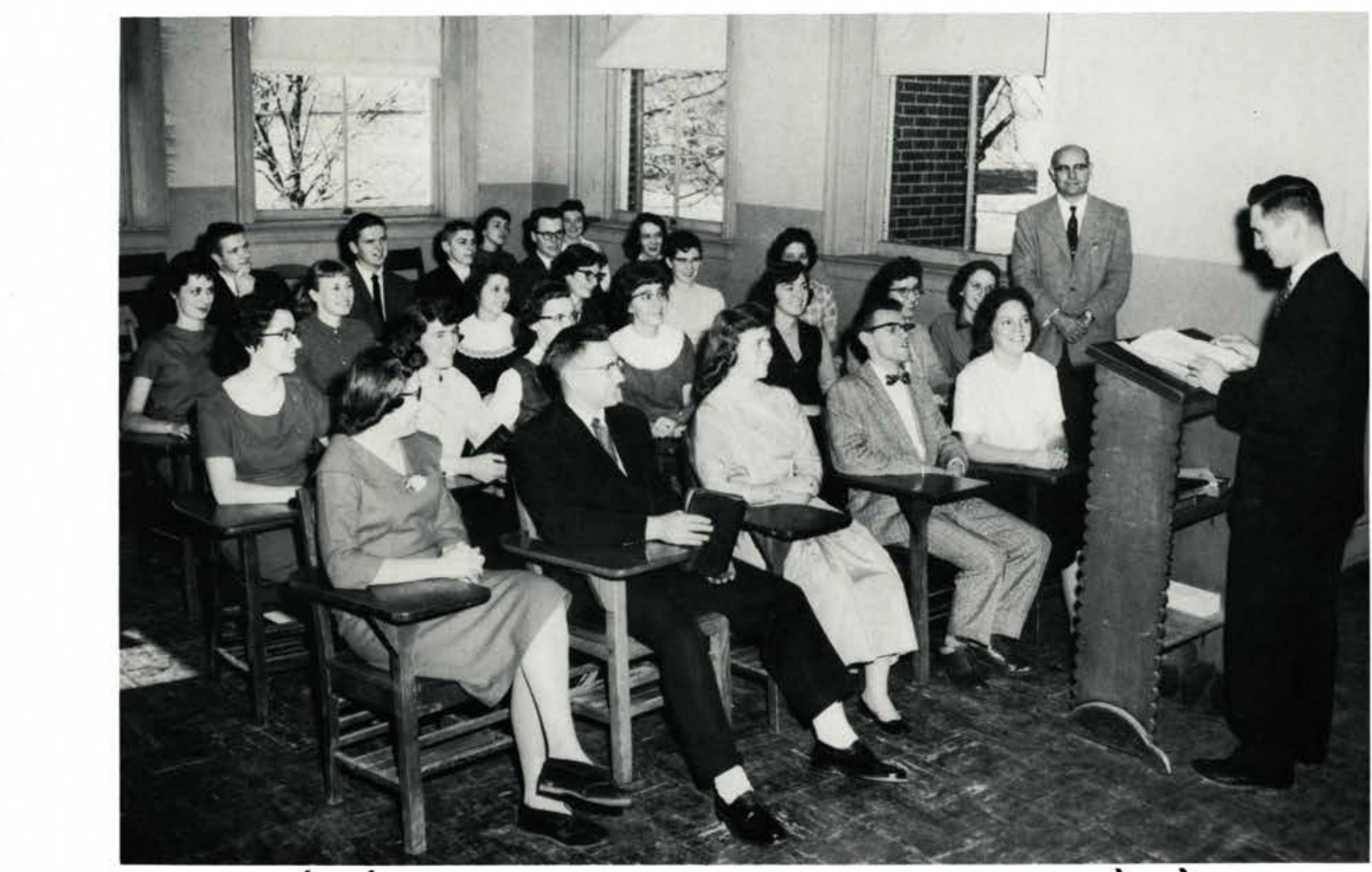

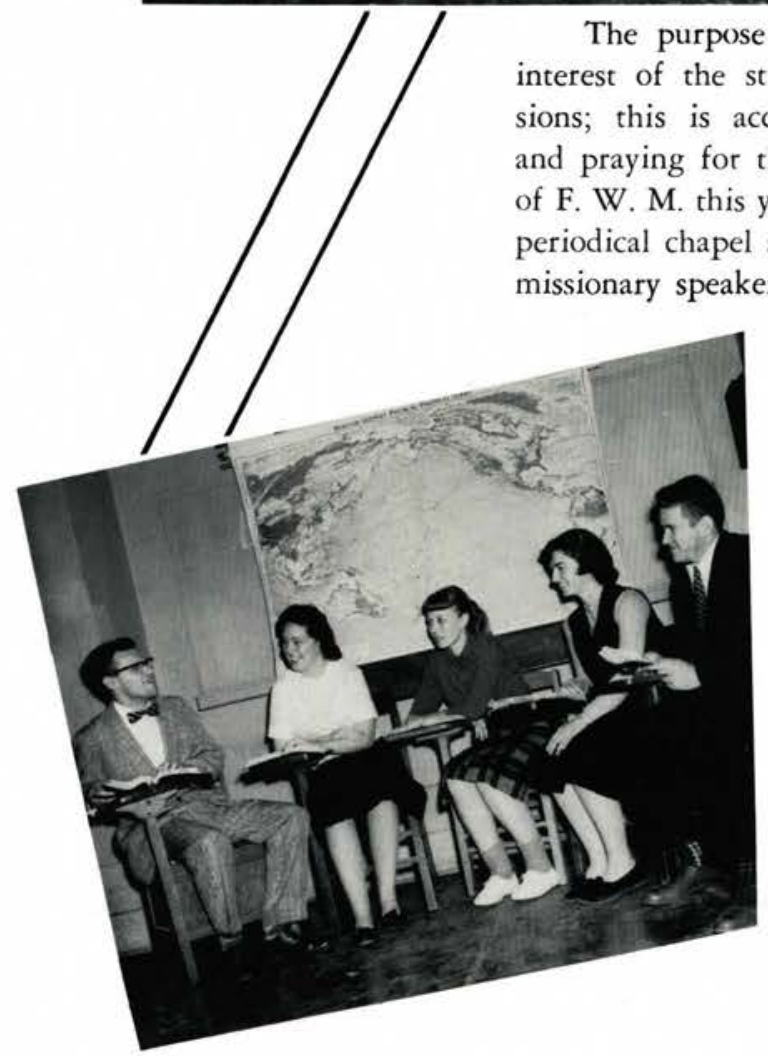

President

Vice-President
MERLIN AGER

DEAN MAYO

\section{Officers}

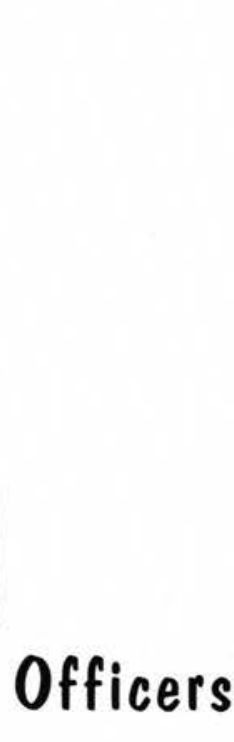

Secretary-Treasurer
Advisor

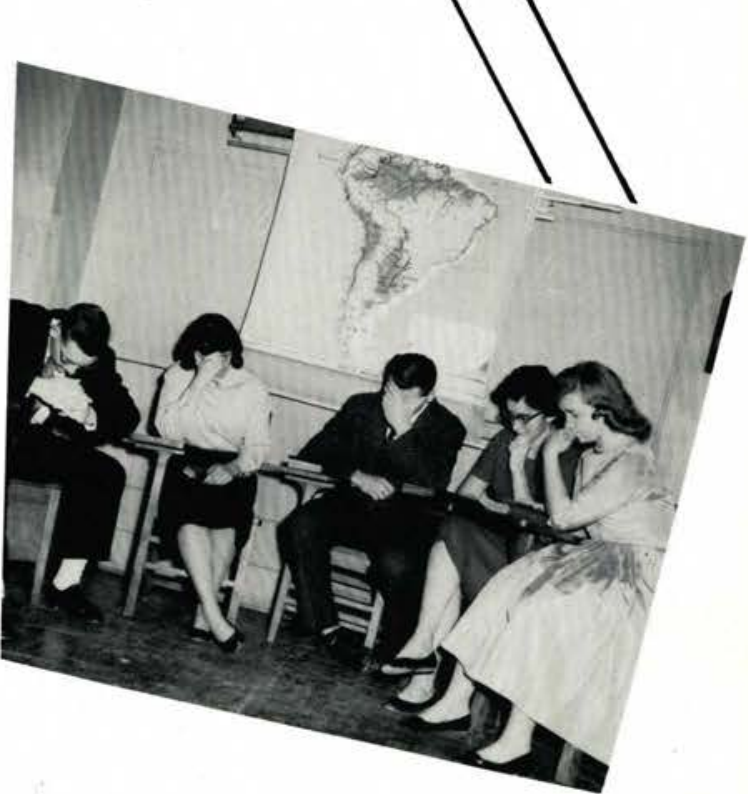

KATHY SHELTON

MR. MC DONALD 


\section{Student Council}

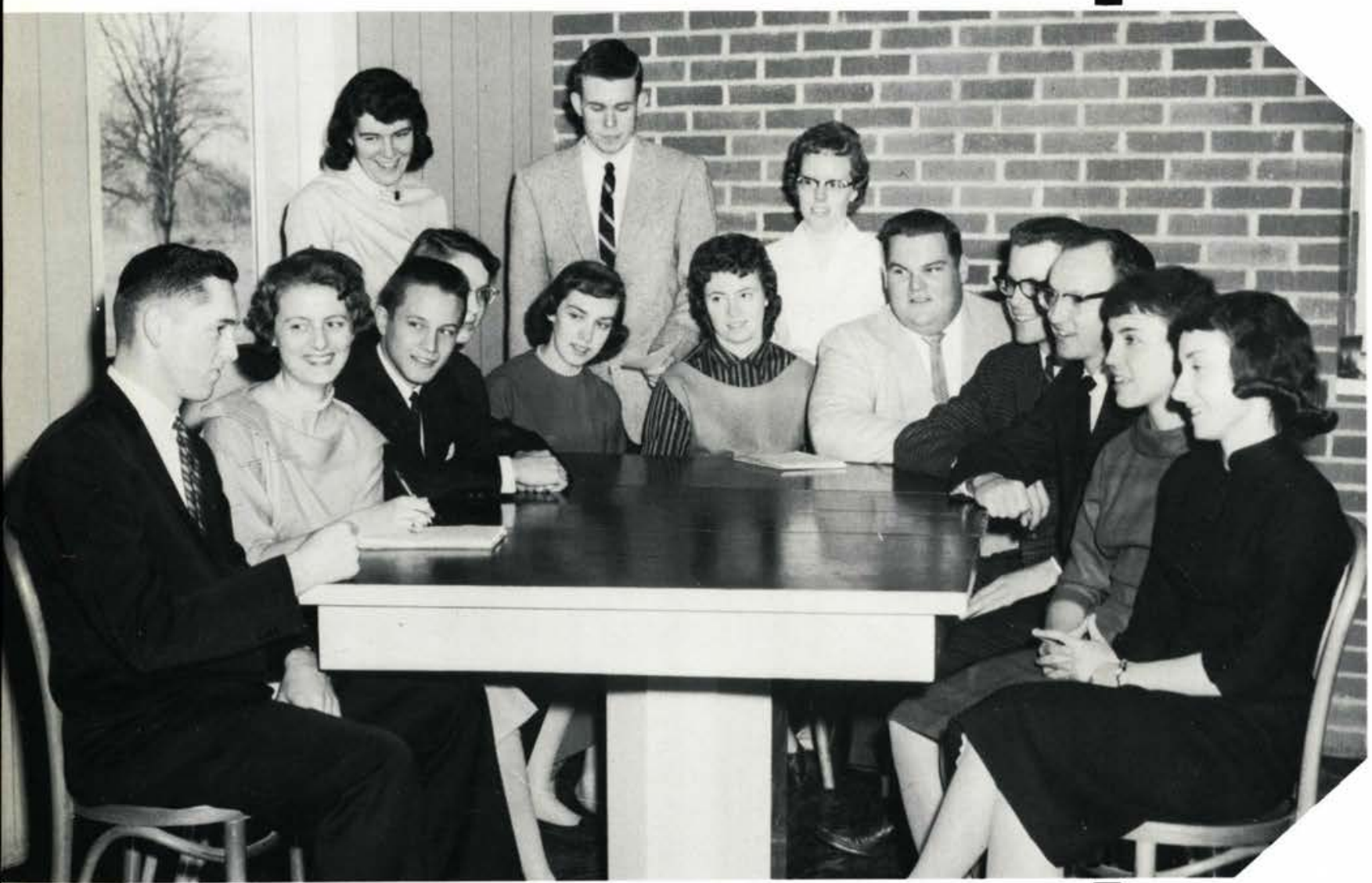

STUDENT COUNCIL. Seated. Left to Right: Merlin Ager, President; Lois Jeremiah Secretary; John Lawlor, Rosemary Smith, Lucy Lyons, JoAnn Watson, Tony Kilbourn, Dwayne Frank, Vice-President; Larry Smith, Esther Weiss, Treasurer; Mary Williams. Standing: Nancy McDivitt, Bogle Standifer, Phyllis Dobbs. Not pictured: Terry Zerby.

This group is an especially busy one, and because of this, has found the need to expand this year. Under the leadership of Dr. Williams, the council has formulated its principles and practices and put them into writing. Many hours were spent in discussing the improvement of rules and disciplinary methods; as a result the student governments were established. Several money-raising projects have been attempted such as self-address stickers, basketball shakers, and cheering pom-poms. 


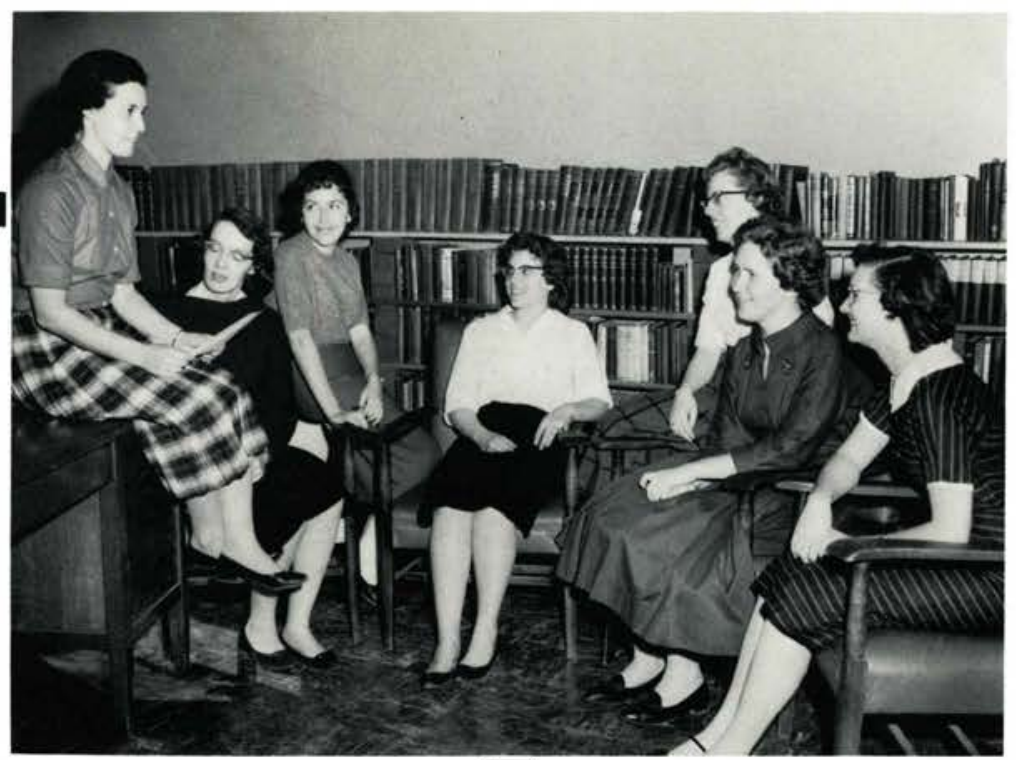

This newly-formed organization, divided into a men's and women's group, was created for the purpose of handling minor discipline problems in the school. Thus far the governments have proved effective in promoting a spiritual atmosphere and helping the students to realize their Christian responsibility in, and attitude toward, matters of discipline.
WOMENS' GOVERNMENT. Left to Right: Eleanor Taylor, Chairman: Rosemary Smith, Sandra Hammerstrom, Carolyn Hale, Phyylis Dobbs, Shirley Harrington, Carol Brown.
MENS' GOVERNMENT. Seated, Left to Right: Horace Ward, Dan Brower, Jim Holcomb, Bob Domokos. Standing: Jack Dowden, Terry Zerby, Dwayne Frank, Chairman.

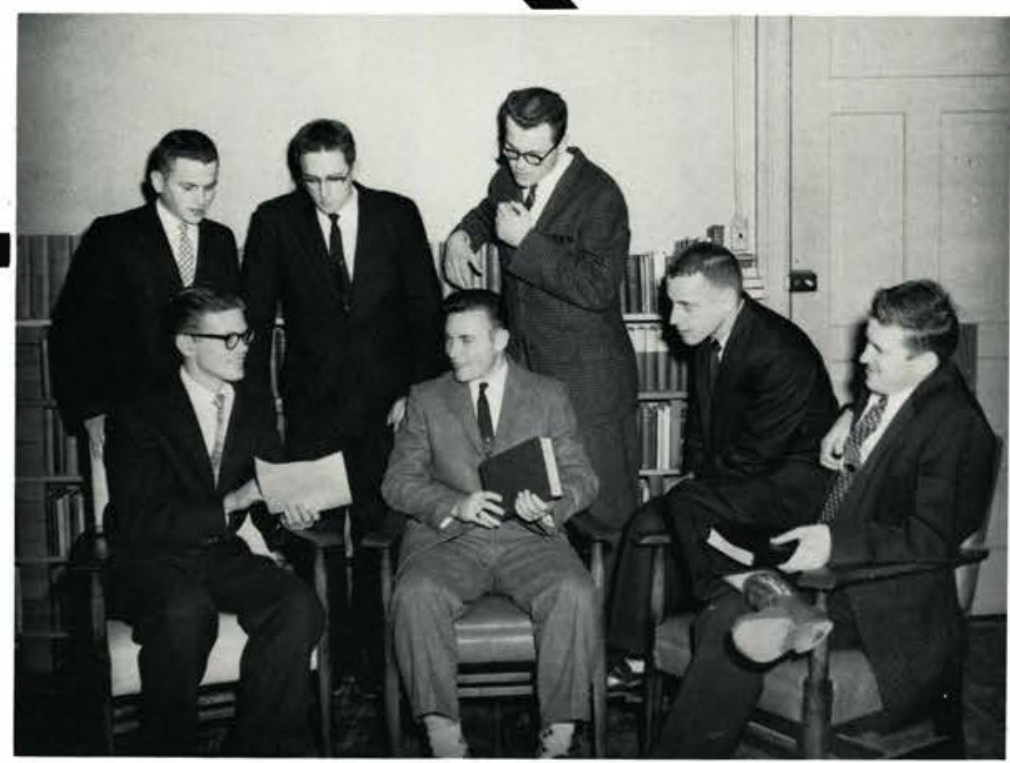

\section{Student Governments}




\section{Gamma}

Chi
Gamma Chi is a literary society which stands for Women for Christ. It seeks to develop its members along literary, musical, artistic, and humorous lines and to develop poise, personality, and leadership at both formal and informal events. Among the meetings for this year was a December meeting on etiquette which was very informative and helpful to the girls. However, the greatest success of the year was the sponsorship of the Valentine Banquet.

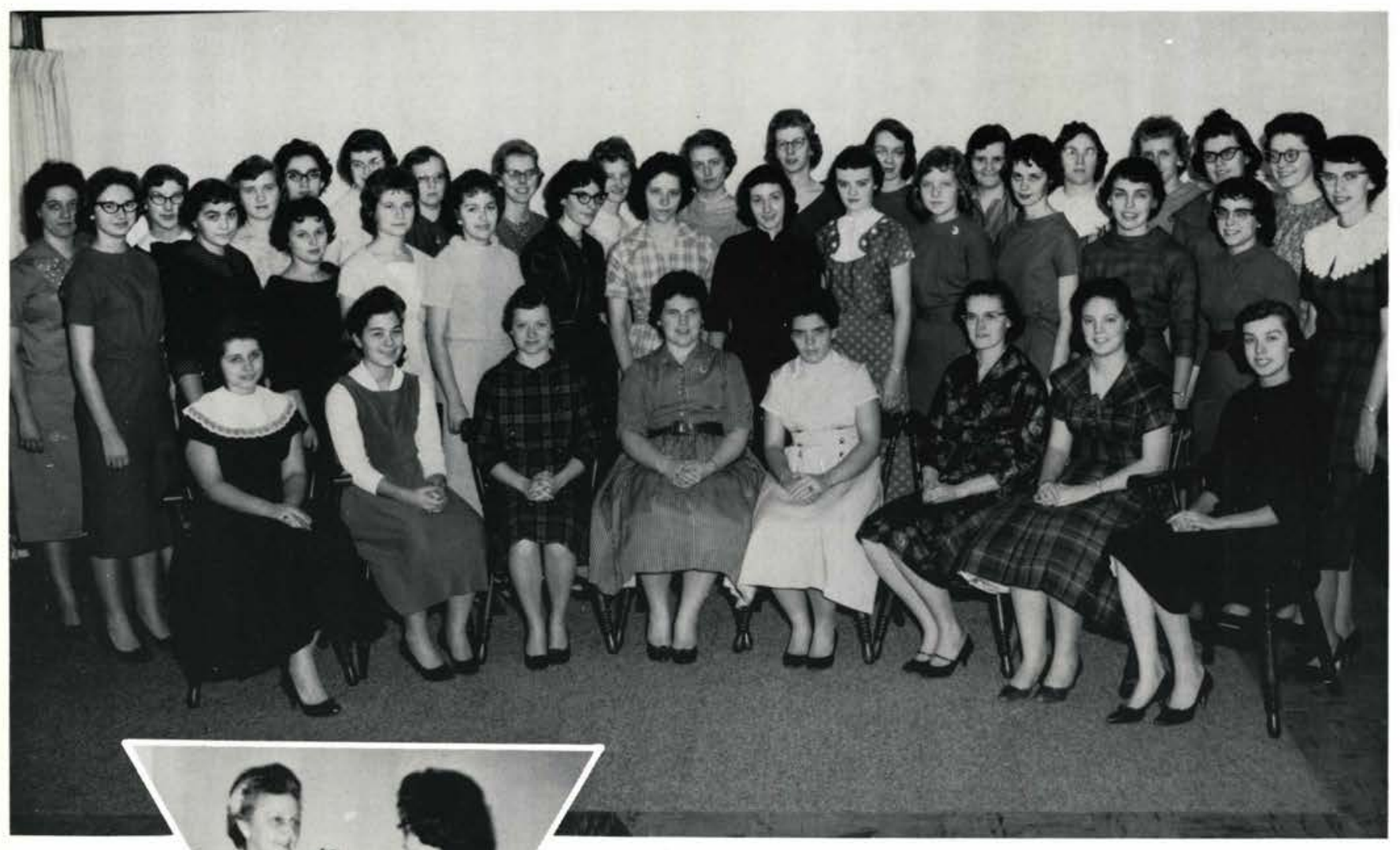

Back Rou: Darlene Derr, Barbara Hemenway, Esther Speith, Julia Bird, Jane Ginz, Aloha Patch, Carol Zoellner, Treasurer; Windy Tyson, Lois Jeremiah, Sally Roudybush, Rosemary Smith, Student Coun. cil Representative; Marilyn VanDeVenne, Joyce Grant, Vice-President; Judy Lachman, Sara Shorts, Nancy Warkentin. Second Row: Betty Smythe, Donna Finley, Barbara Mitchell, Carol Hell, Sandra Hammerstrom, Program Chairman; Cathy Walmsley, Peggy Buerer, Mary Williams, Louise Varisco, Carol Hensen, Flora Cannon, Esther Weiss, Parliamentarian; Carolyn Hale, President; Peggy Getty. Front Row: Marlene Davis, Secretary; Jeannie DuPre, Pat Petry, Barbara Swertfager, Janet McClish, Jean Lockerbie, Marilyn Campbell, Lucy Lyons, Social Chairman; Mrs. Munger, Advisor.

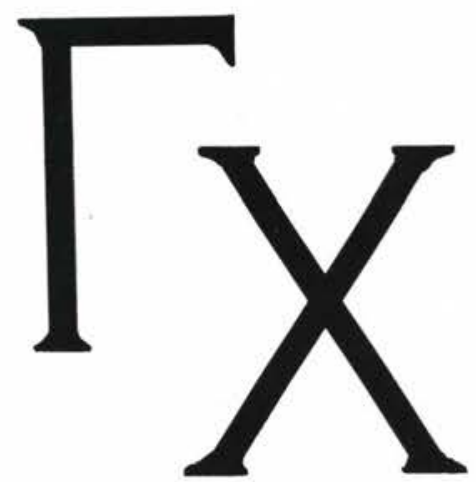


Alpha Chi, Men for Christ, is a men's literary society with open membership to all men of Cedarville College. Its primary purpose is the cultivation of Christian personality and leadership. The programs of Alpha Chi stimulate originality and growth along literary, musical, artistic, and humorous lines. The secondary purpose of the club is entertainment. The society began the year with a combined initiation ceremony with Gamma Chi. Taking charge of the Thanksgiving Banquet was its main project for the year.

\section{Alpha}

\section{$\mathrm{Chi}$}

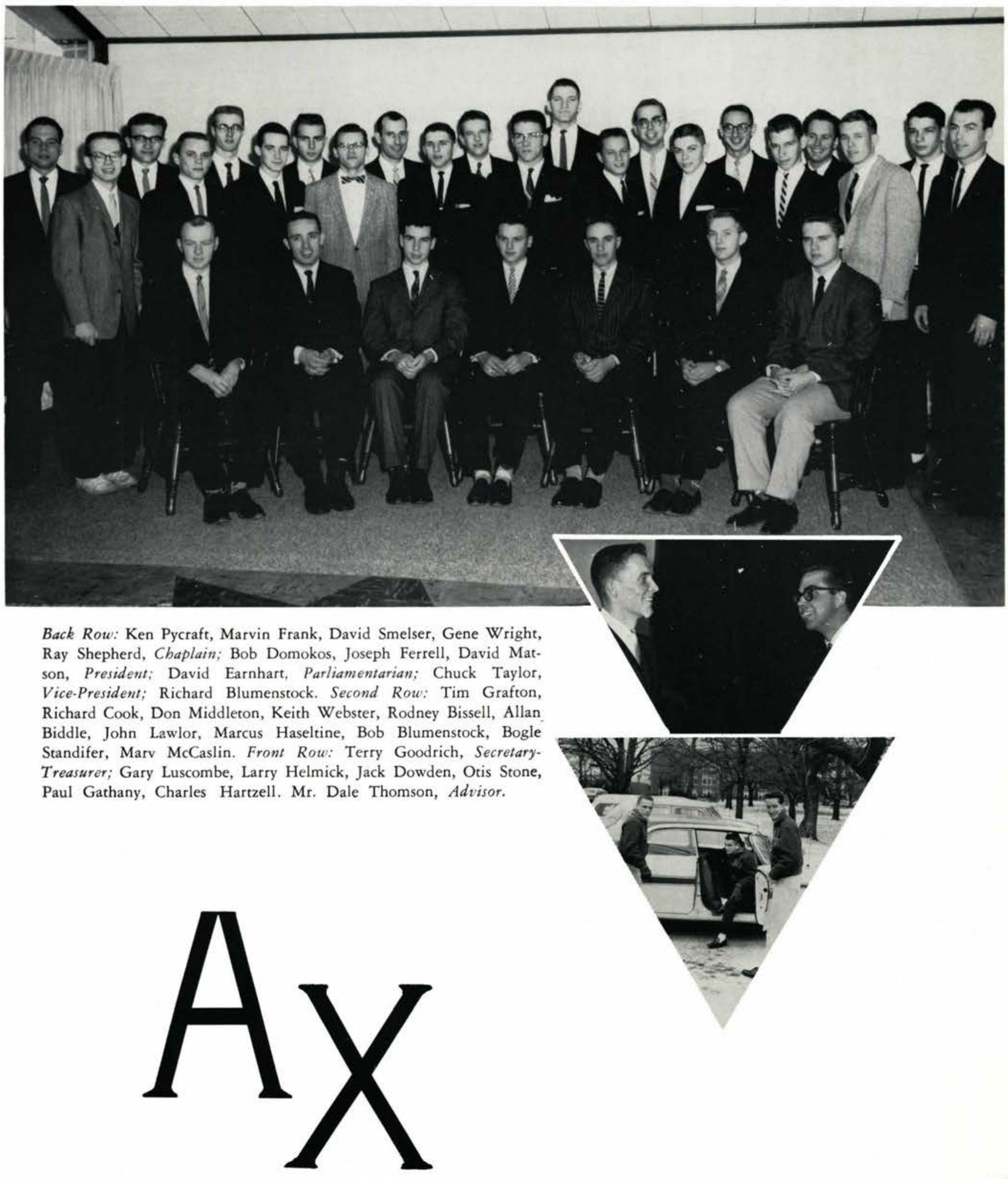




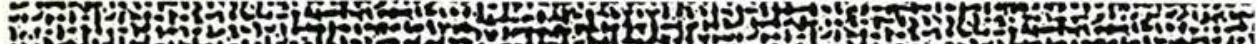
î A. 7 H

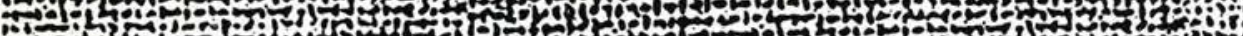
a.t. a.

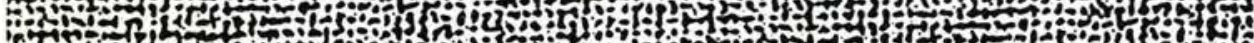
a 2.

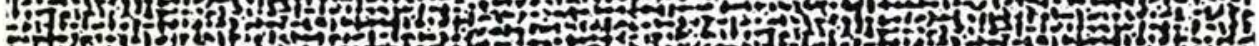
20

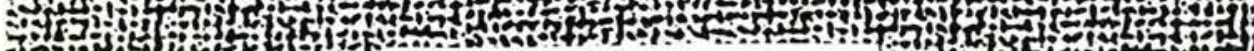
Tr. is:300 1 int:70.7\% : isolite

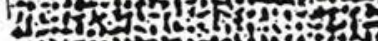
Fition Tơ

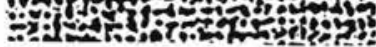

In all these things we are more than conquerors through $\mathrm{Him}$ that loved us" (Romans 8:37). This is the theme of the Varsity " $\mathrm{C}$ " Club, which strives to keep the standard of intercollegiate athletics on a Christian basis. The club found last year's project - the popcorn machine - to be so successful that this year they were able to purchase a Whirlpool bath to be used in giving treatment for various injuries.

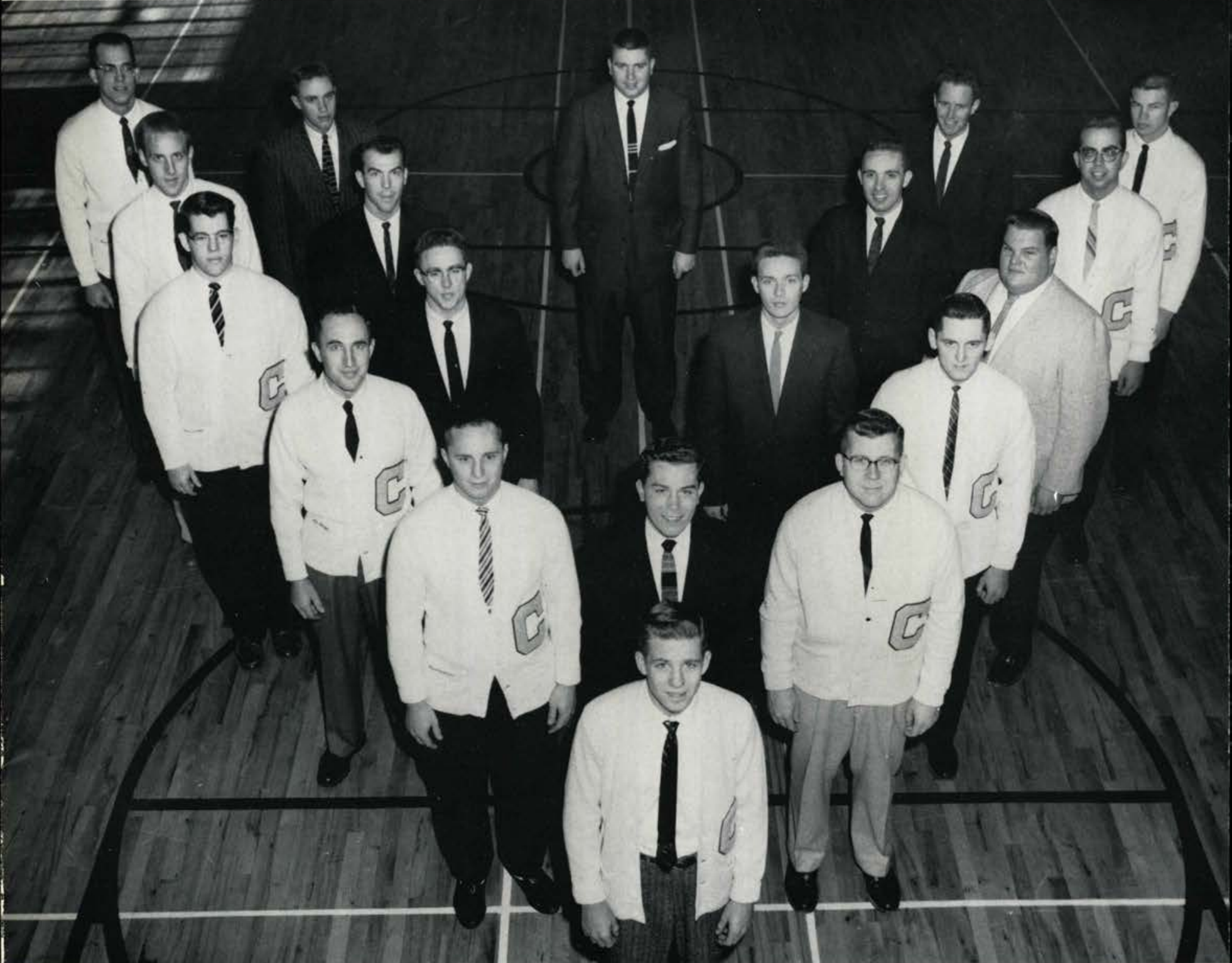

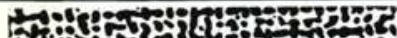

TH

ถ้น

ThL

73

(X) Pin

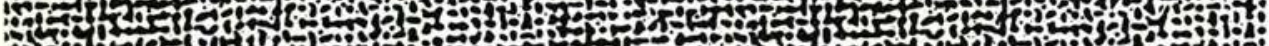

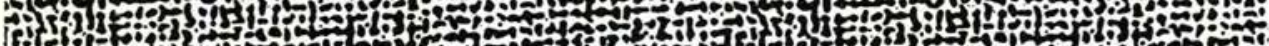
Ars 2.7. P. H 11.24 19.01 50 . 1.020 1.0.0.

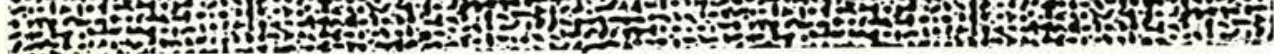

Coach Bowser, Advisor: Bob Humphreys, President: Dave Dantel, Vice. President: Dave Matson, Secretary: Pete Reese, Treasurer: John Entner, Business Manager: Merlin Ager, Co. Business Manager: Tony Kilbourn, Chaplain: Roy Carr, Jim Entner, Otis Stone, Naw McCaslin, Terry Zerby, Stu Chaffe, Dave Cochran, Keith Collett, Ted Walborn, Dave Lewis, Gary Luscombe, Chuck Taylor. 
In the second year of existence, the Dramatics Club established its name, Sock 'n Buskin, and carried out an ambitious program, which included the showing of the film, "Great Expectations" and the presentation of a one-act play.

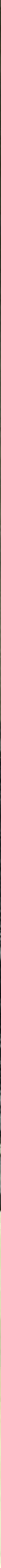




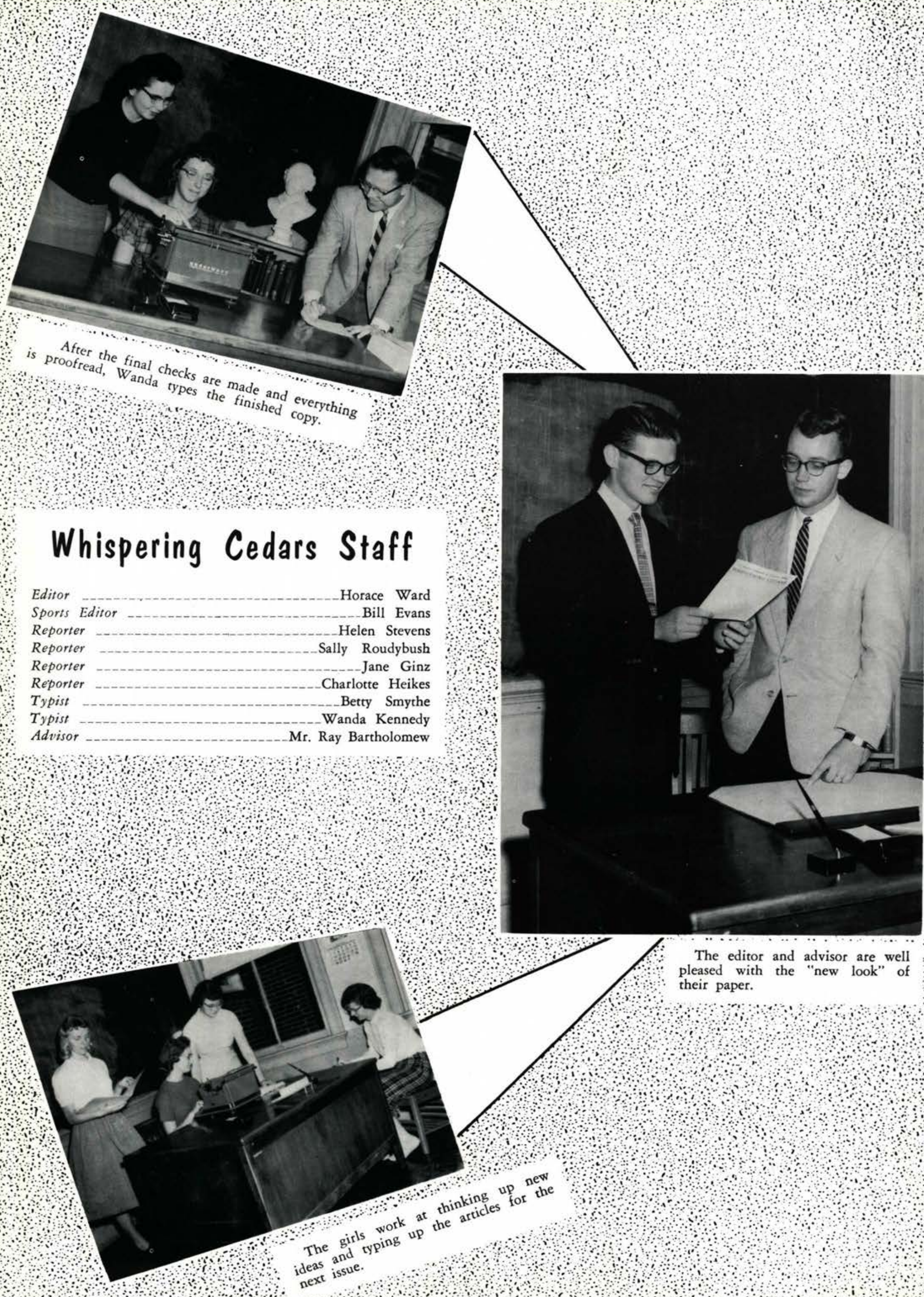




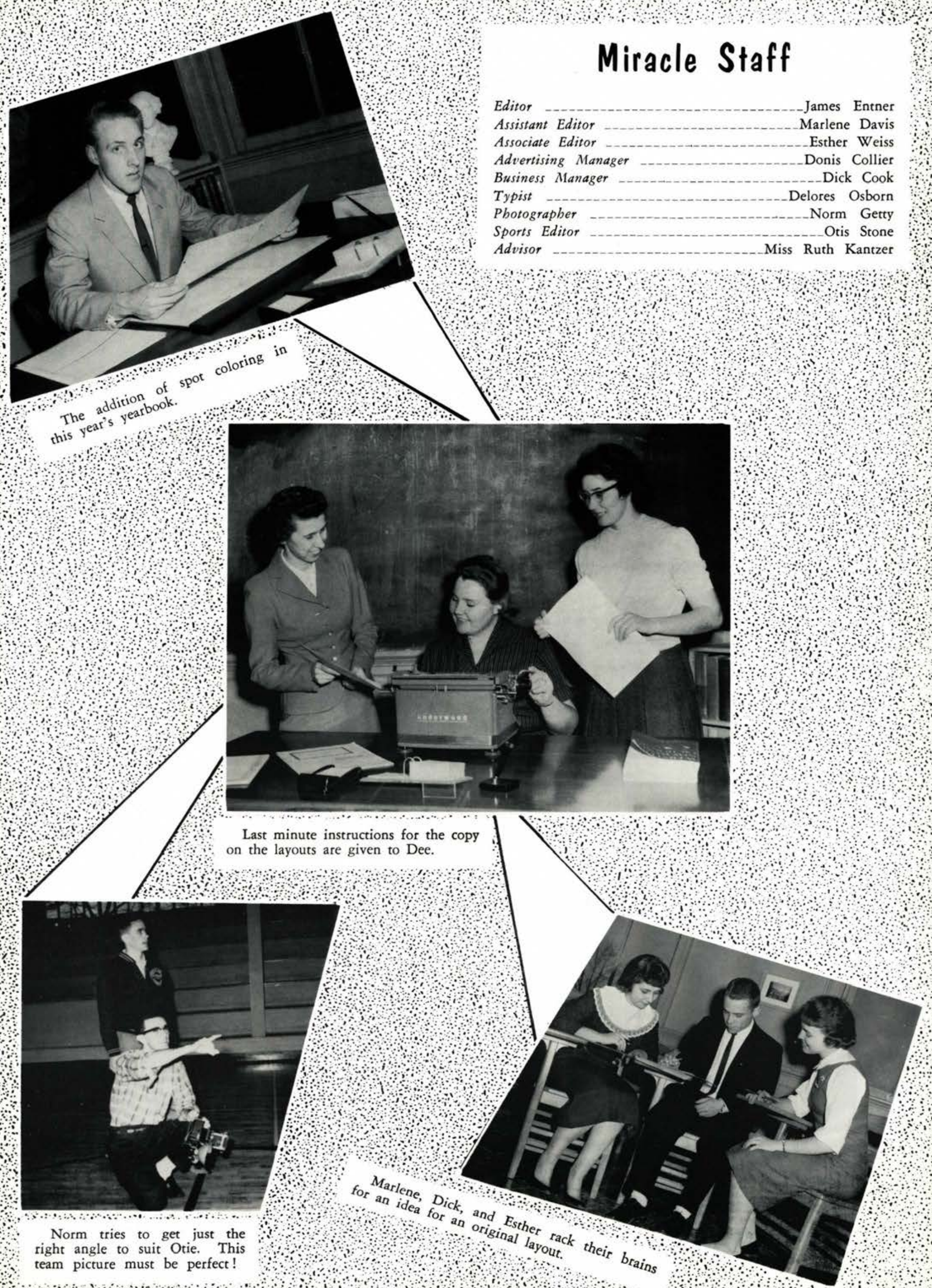



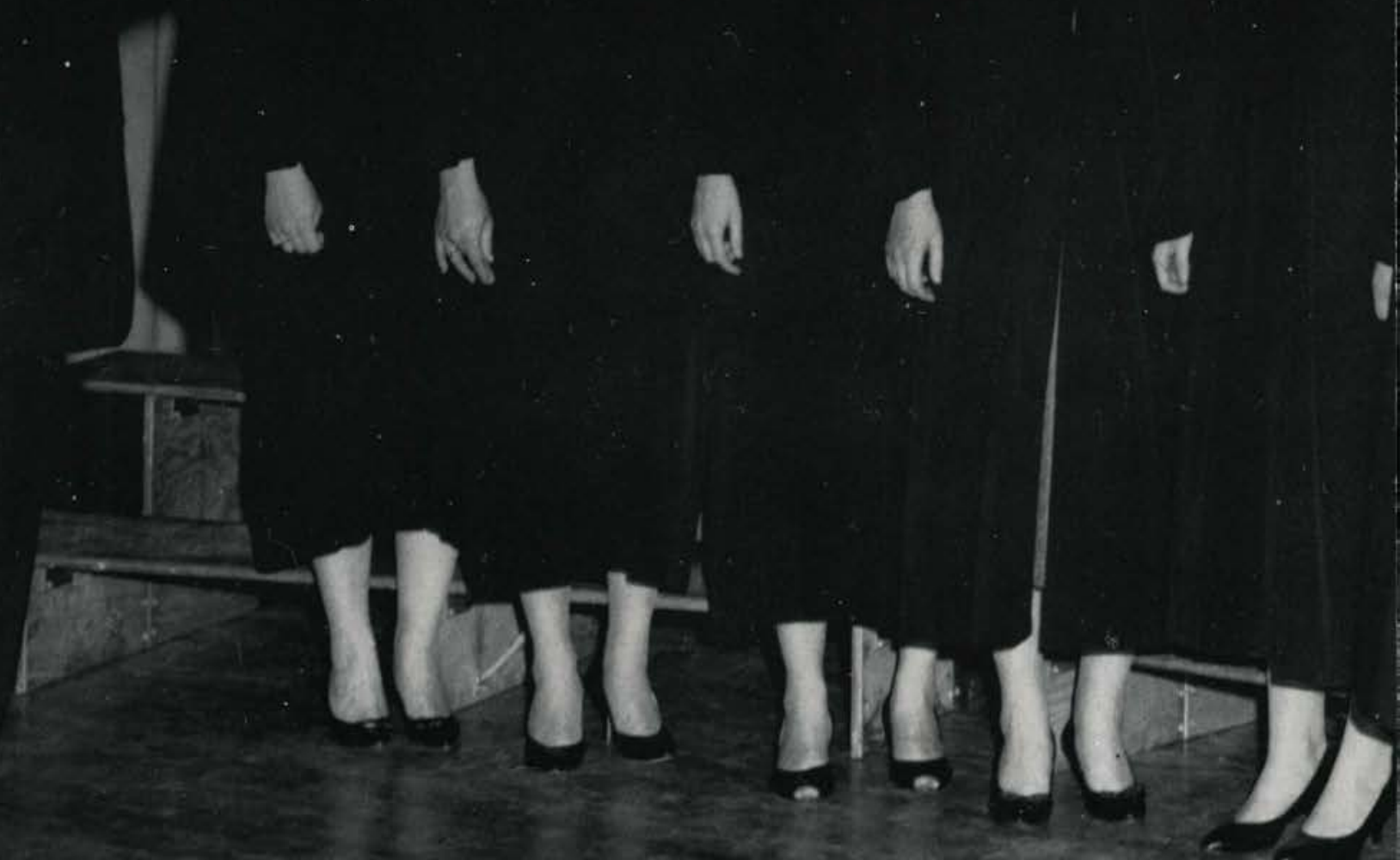


\section{Music!}
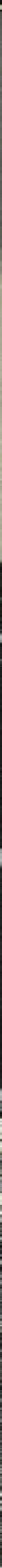


\section{College Choir}

The College Choir, (pictured on page 40 and 41 ), with a new director, Mr. Richard Cooke, and 50 per cent new members this year, wasted no time in preparing their program and singing together. This group, composed of 38 members, has gone out on many weekend trips presenting sermons in song for the glory of the Lord.

Back Row: John Lawlor, Jim Strolle, Ray Shepherd, Dave Matson, John Butler, Marvin Royse, Dave Jeremiah, Dave Earnhart, Sam Canine, Ralph Werner, Lynn Jefson. Second Row: Dick Cook, Carol Henson, June Golden, Dolly Jesse, Shirley Harrington, Lois Jeremiah, Carol Zoellner, Judy Lachman, Jean Lockerbie, Gail Carter, Jack Dowden. Front Row: Carolyn Hale, Esther Weiss, Carol Brown, Eleanor Taylor, Delores Rucker, Donna Finley, Lucy Lyon, Pat Petry, Marlene Davis. Mr. Richard Cooke, Director.

\section{Chapel Choir}

The Chapel Choir, under the patient direction of Mr. Zinn, is a new organization at Cedarville College. Its main purpose is to train young people in choral singing. Two appearances made by the choir this year include the Christmas Concert and a trip to Sunbury, Ohio.

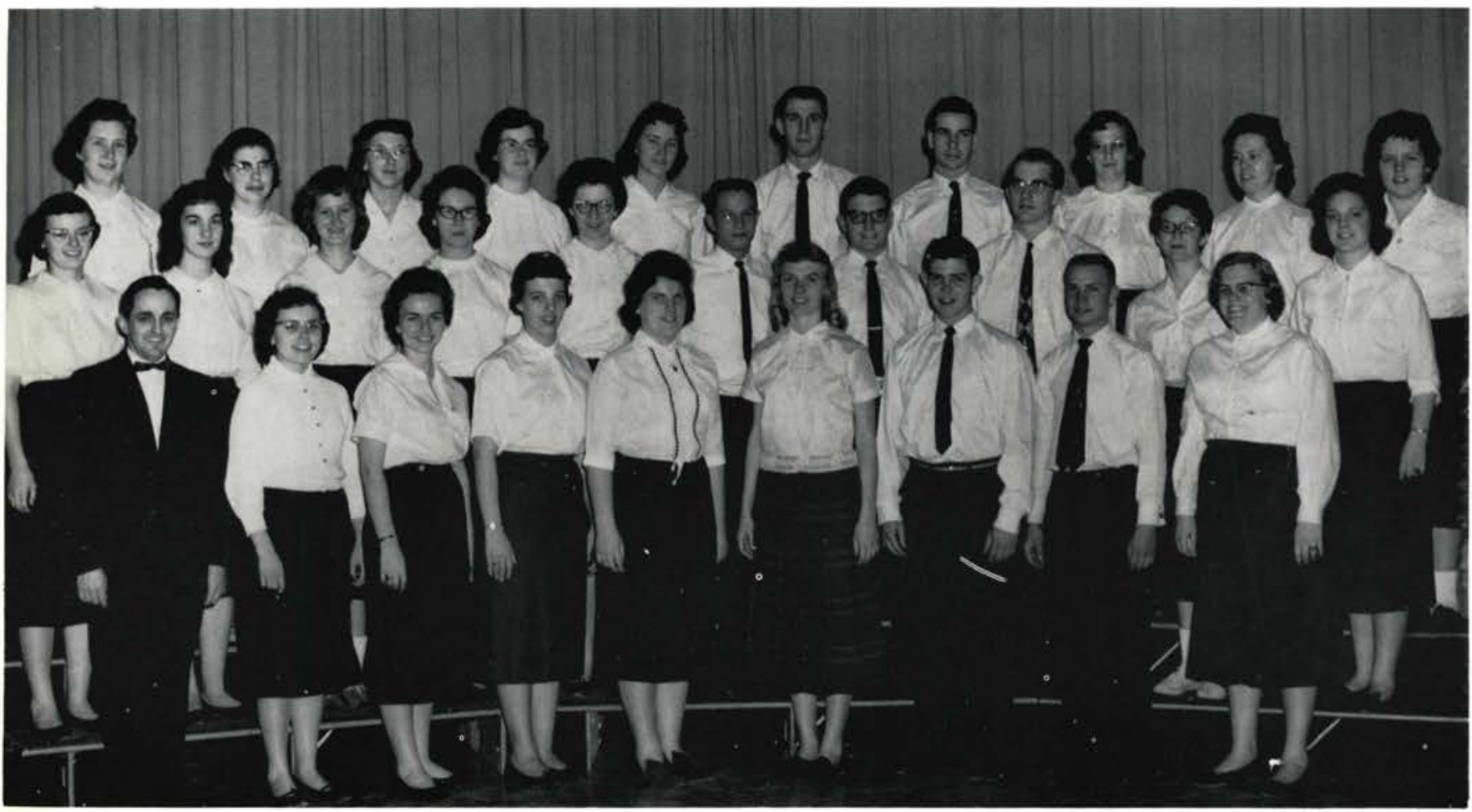

Back Rou: Shirley Harrington, Margaret Powers, Wanda Kennedy, Jane Ginz, Betty Rose, Leigh Betts, Larry Helmick, Aloha Patch, Gweneth Bennett, Pat Lambert. Second Rou: Louise Varisco, Nancy Shimits, Windy Tyson, Betty Smythe, Nancy Warkentin, John Lawlor, Tom Cetas, Ralph Werner, Betty Smith, Marilyn Campbell. Front Rou: Mr. George Zinn, Director; Pat Schonsheck, Gail Carter, Marcia Ratcliff, Barbara Swertfager, Charlotte Heikes, Gary Hogard, Neil Amstutz, Carol Tatro. 


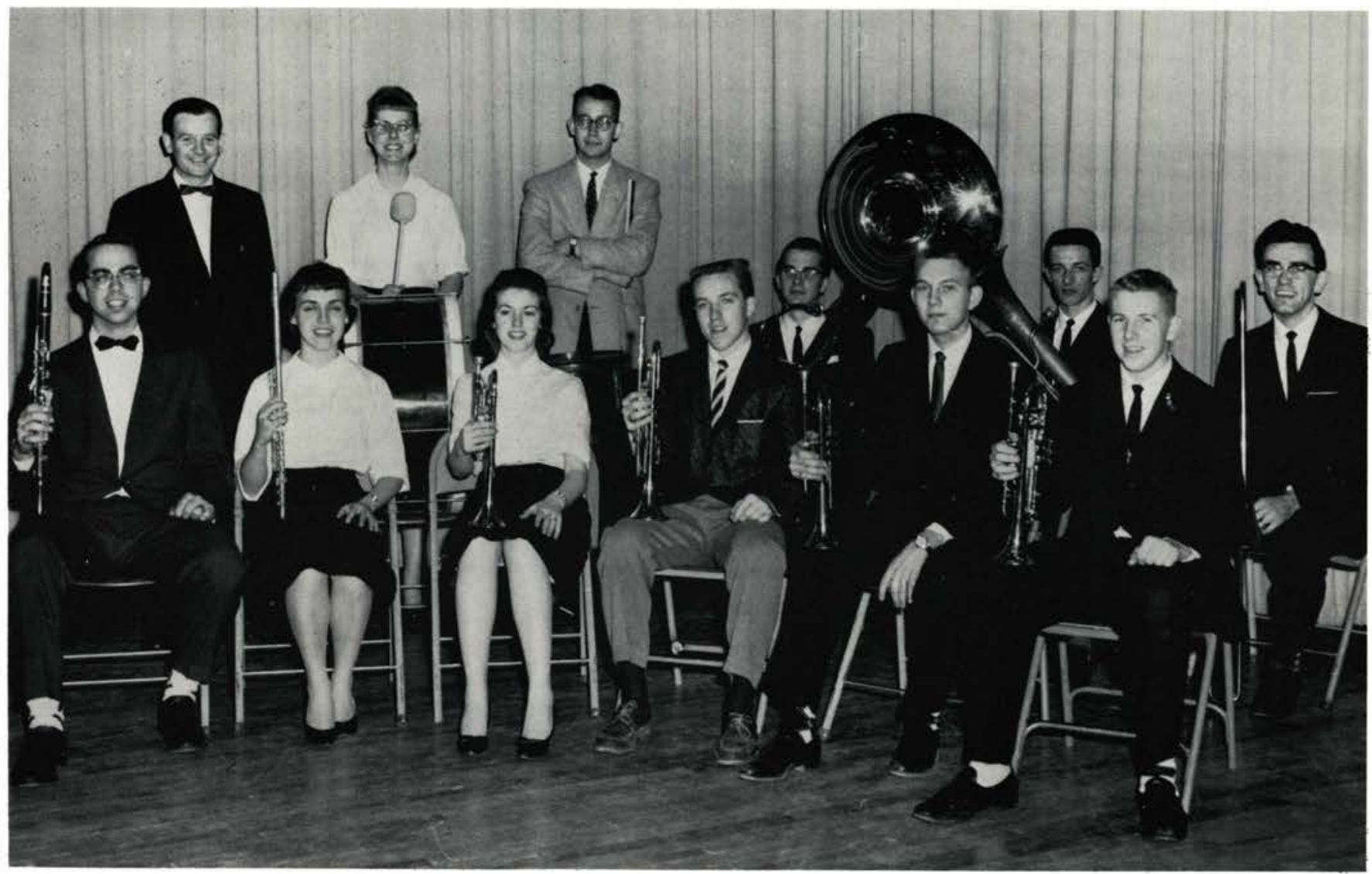

Back Row, Left to Right: Mr. Webber, Director: Carol Zoellner, Librarian; Mr. Bartholomew, Ralph Werner, Norris Smith, Mornam Getty. Front Rou: Dave Matson, President: Esther Weiss, Vice-President; June Golden, Ed Eastman, Paul Gathany, Phil Grant. Not Pictured: Don Adams, Marcia Crothers, Secretary; Rosemary Smith, Shirley Harrington, Carol Boren, Charles Hartzell, Peggy Getty, Joyce Grant.

\section{Chamber Band}

The Chamber Band, a new organization, has made several appearances throughout the year, including the annual Christmas Concert. It favors the playing of music that has historical significance, along with the familiar marches and novelty numbers. 


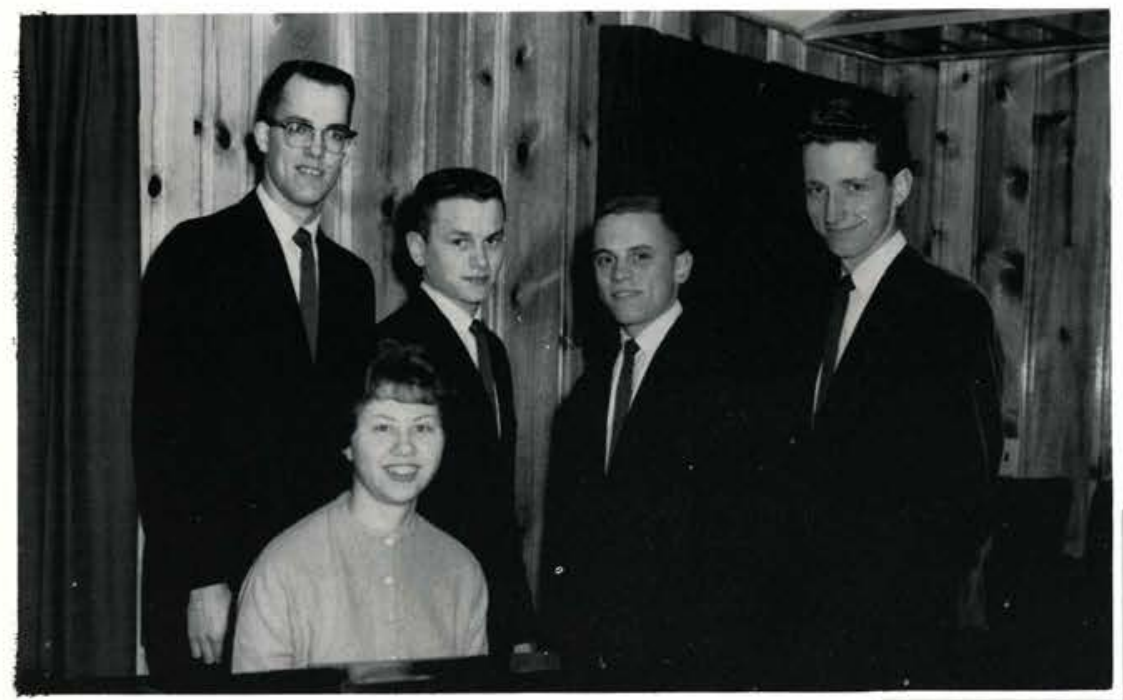

\section{KINSMEN QUARTET}

Left to Right: Roy Carr, Jack Dowden, Dick Cook, Warren Woodard. Seated: Marcia Crothers.

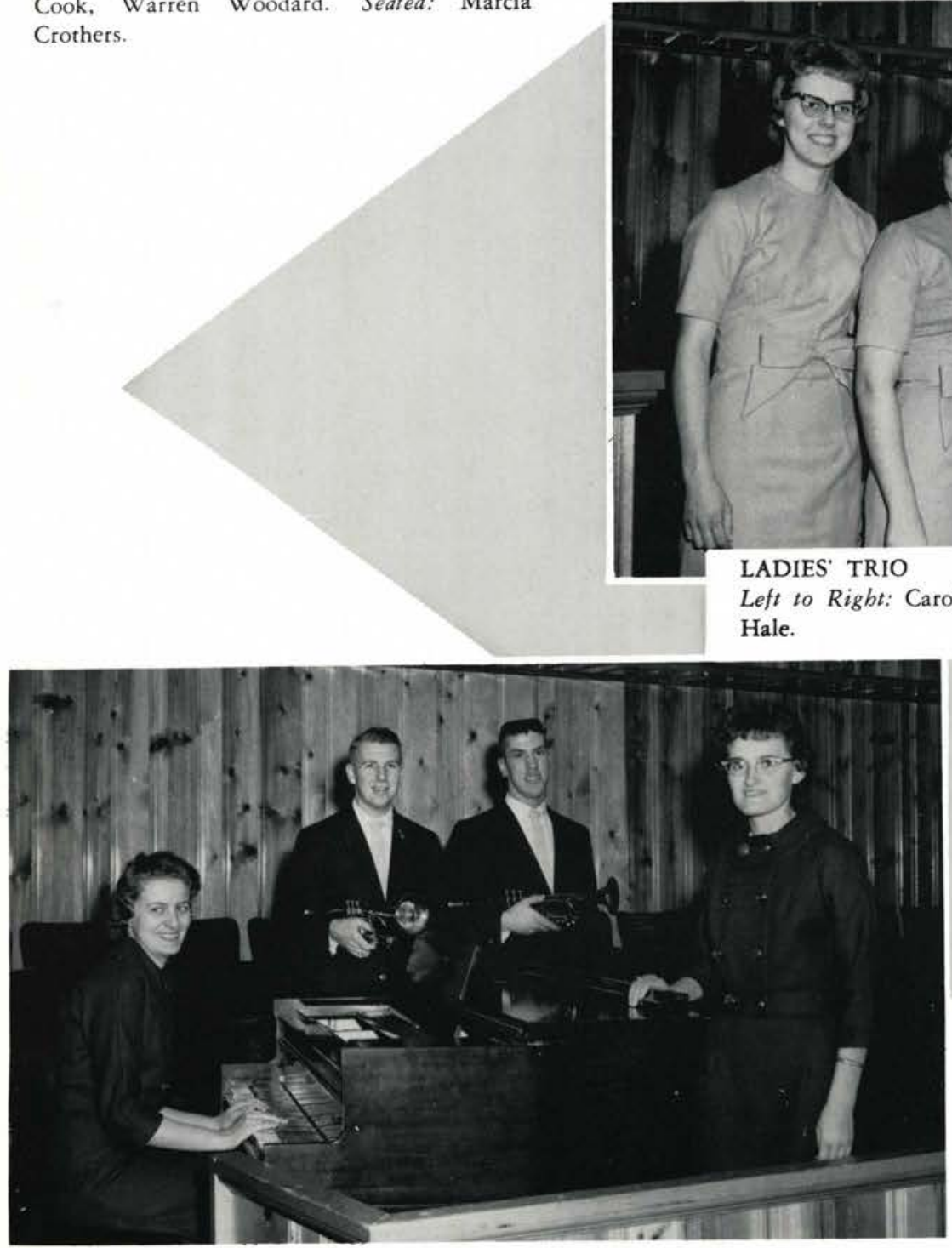

The small music groups, made up of students who are chosen because of their talent and ability, travel many weekends throughout the year to churches and other special meetings to take part in the programs. They are sent out as representatives of the school with the main purpose being to serve and glorify the Lord.

THE GOSPEL HERALDS

Left to Right: Lois Jeremiah, Phil Grant, Don Adams, Jean Lockerbie. 

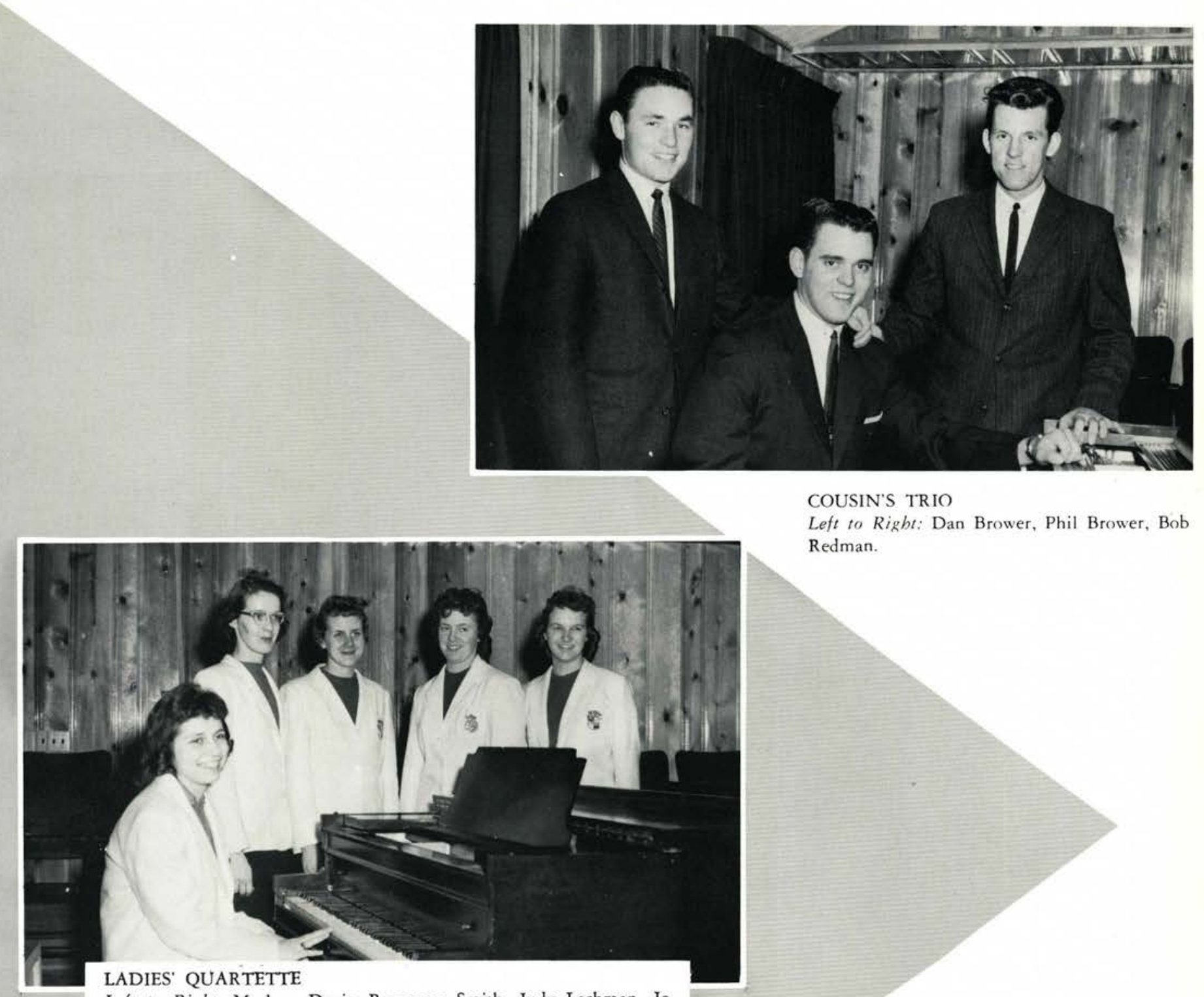

COUSIN'S TRIO

Left to Right: Dan Brower, Phil Brower, Bob Redman.

Left to Right: Marlene Davis, Rosemary Smith, Judy Lachman, JoAnn Watson, Dolly Jesse.

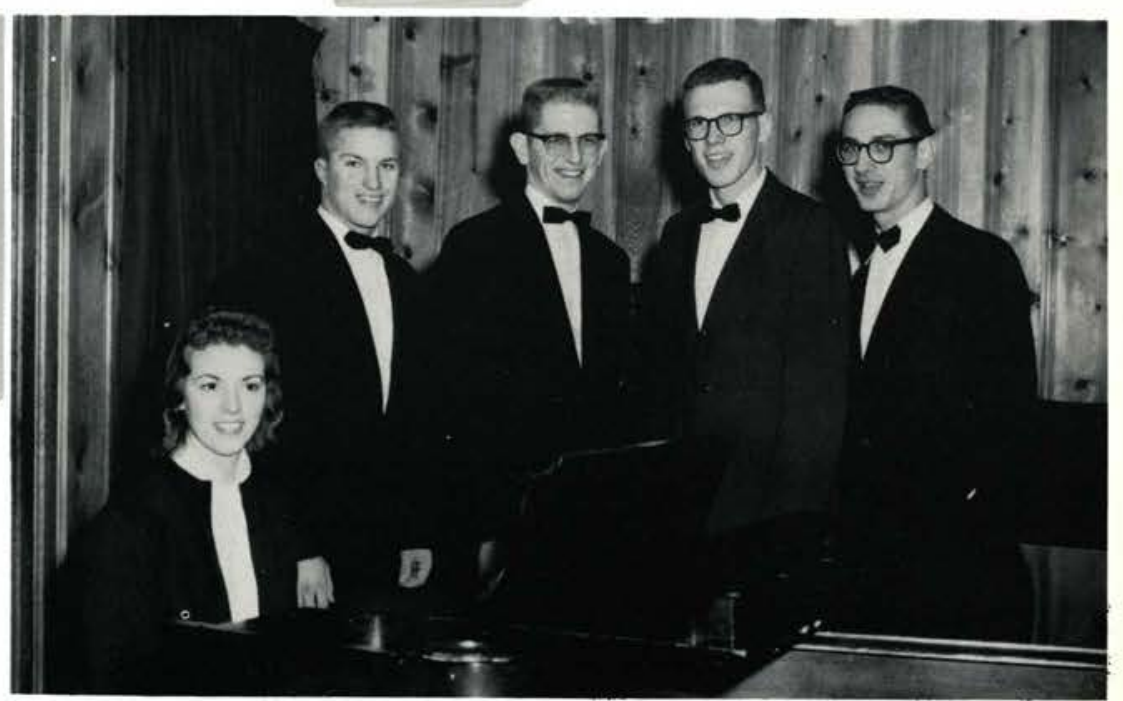

CRUSADERS' QUARTET

Left to Right: June Golden, Lynn Jefson, Vance Ashley, John Butler, Dave Earnhart. 
Each year students who are outstanding in leadership, scholarship, cooperation, character, and service are chosen for membership in the Modern Music Masters, a National Honor Society. The purpose of this society is to foster a greater and continued interest in the spirit of good music and musicianship among its members as well as other students. Tri-M has sponsored several concerts, Artists Series, and other musical programs throughout the past year.

\section{Modern Music Masters}

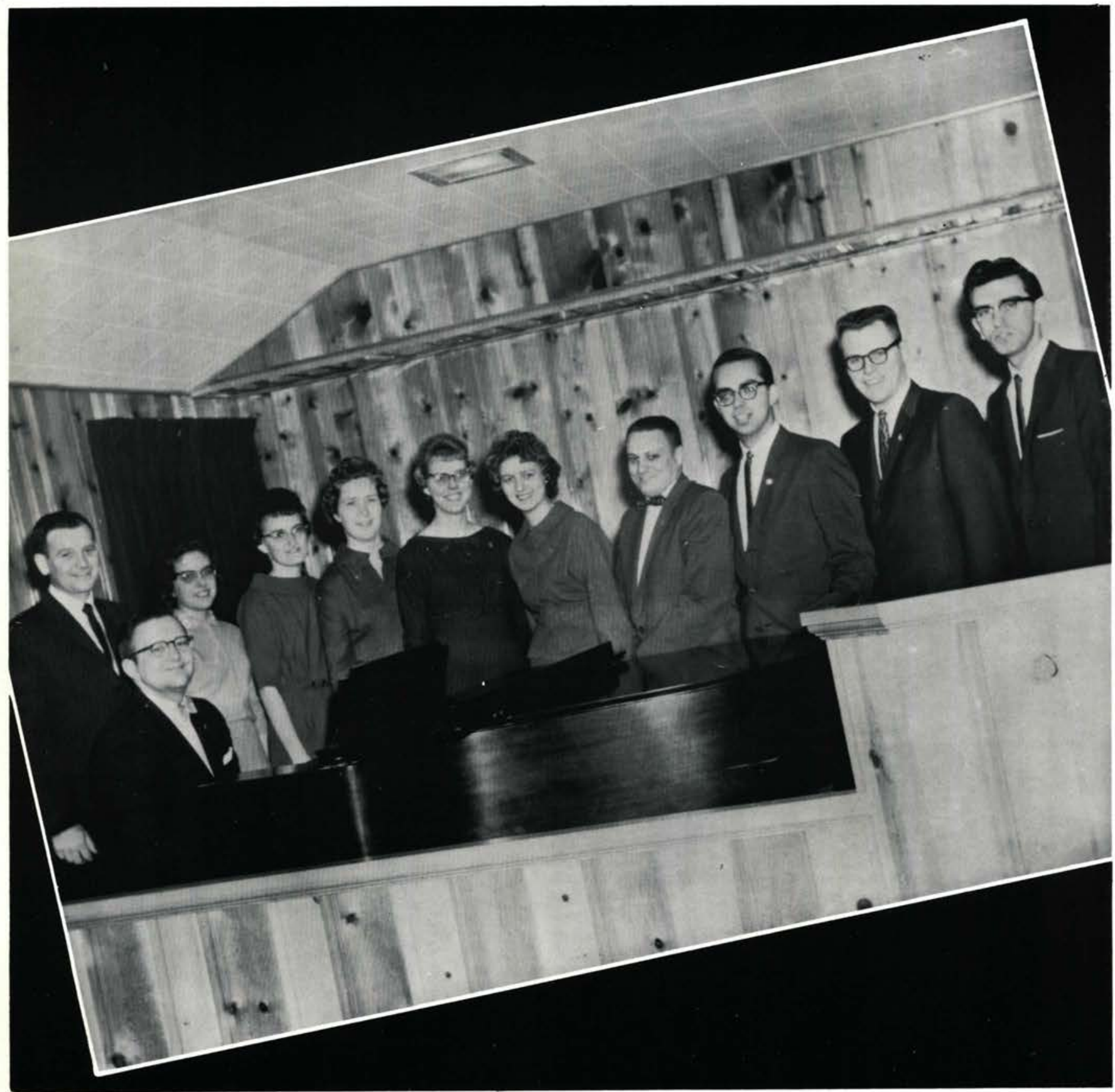

Left to Right: Mr. Webber, Advisor; Mr. Cooke, Advisor; Carolyn Hale, Jean Lockerbie, Shirley Harrington, Historian; Carol Zoellner, Secretary; Lois Jeremiah, Vice-President; Jim Neely, Treasurer; Dave Matson, President; Dwayne Frank, Norman Getty. 


\section{Christian Service}

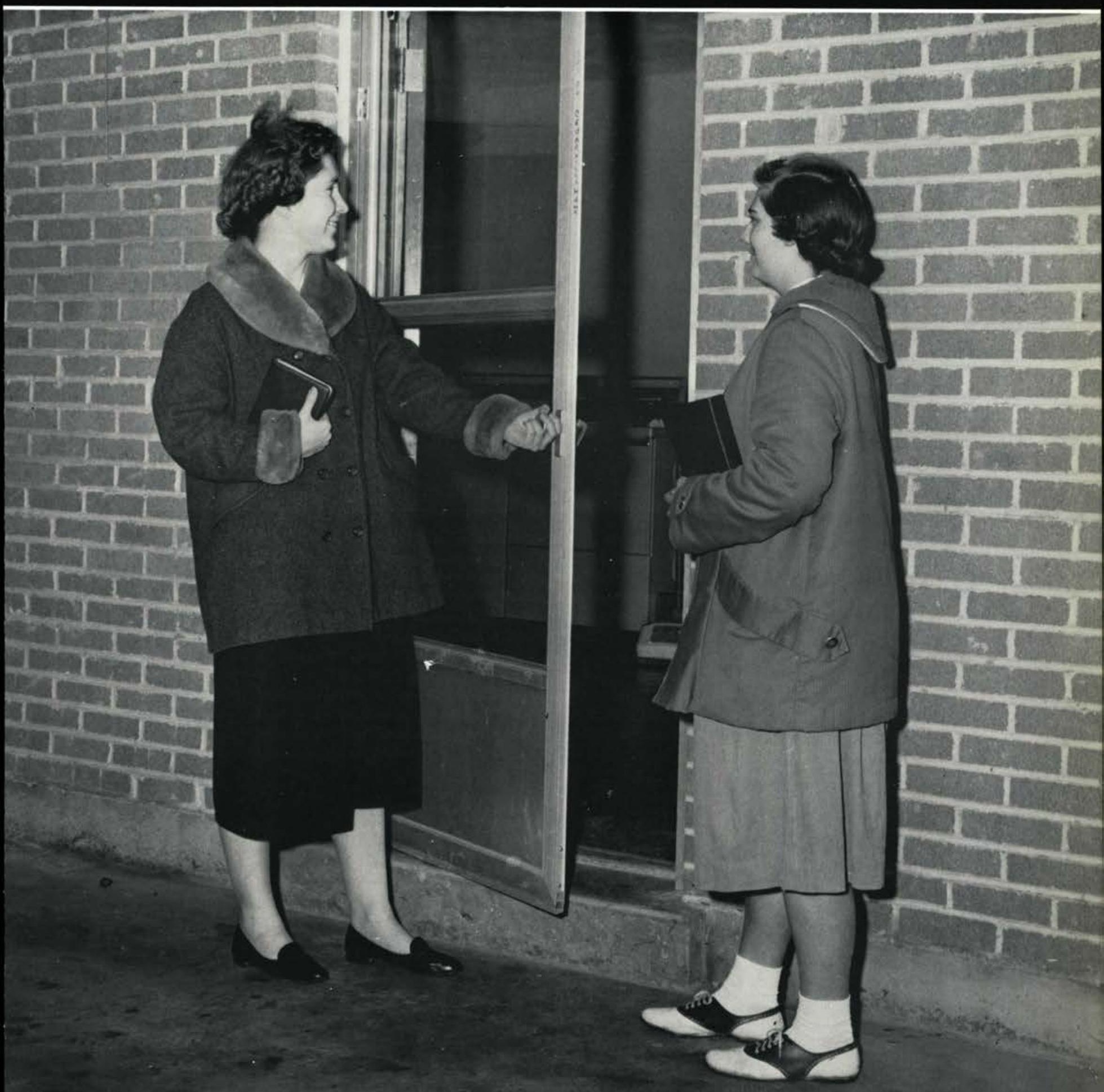




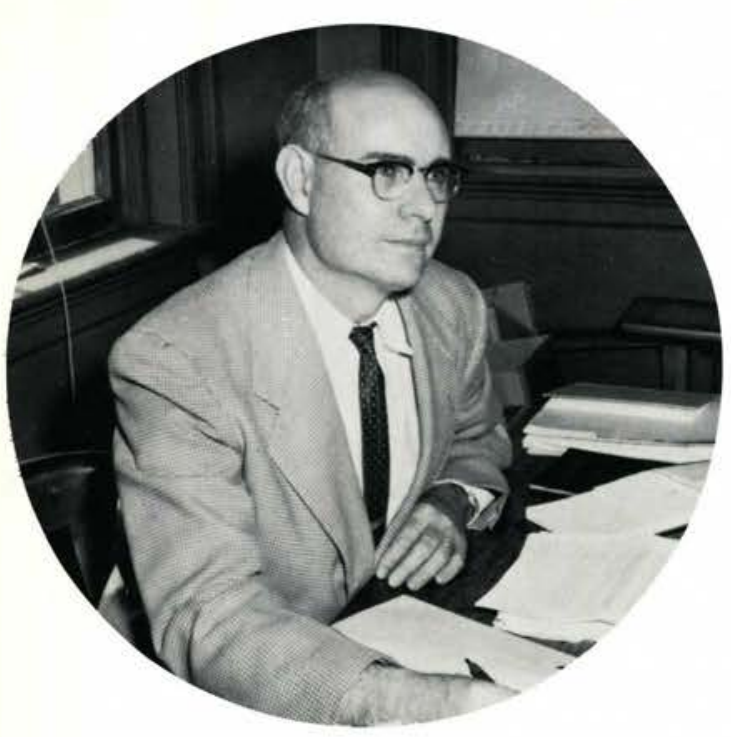

This year the open door to our Christian Service Department, under the direction of Mr. McDonald, became a glowing beacon as students performed their work assignments. New opportunities for service opened to the students included counseling with the youth in the detention home in Springfield and conducting a Sunday School at the O.S.S.O. children's home in Xenia. These varied outlets in surrounding areas have offered valuable experience and have challenged each student throughout this year. But the light must not stop here. This experience merely foreshadows our beacon of service for Christ in the future. Through our many graduates its rays extend far beyond, even to the ends of the earth.

MR. CLEVELAND MC DONALD, Director

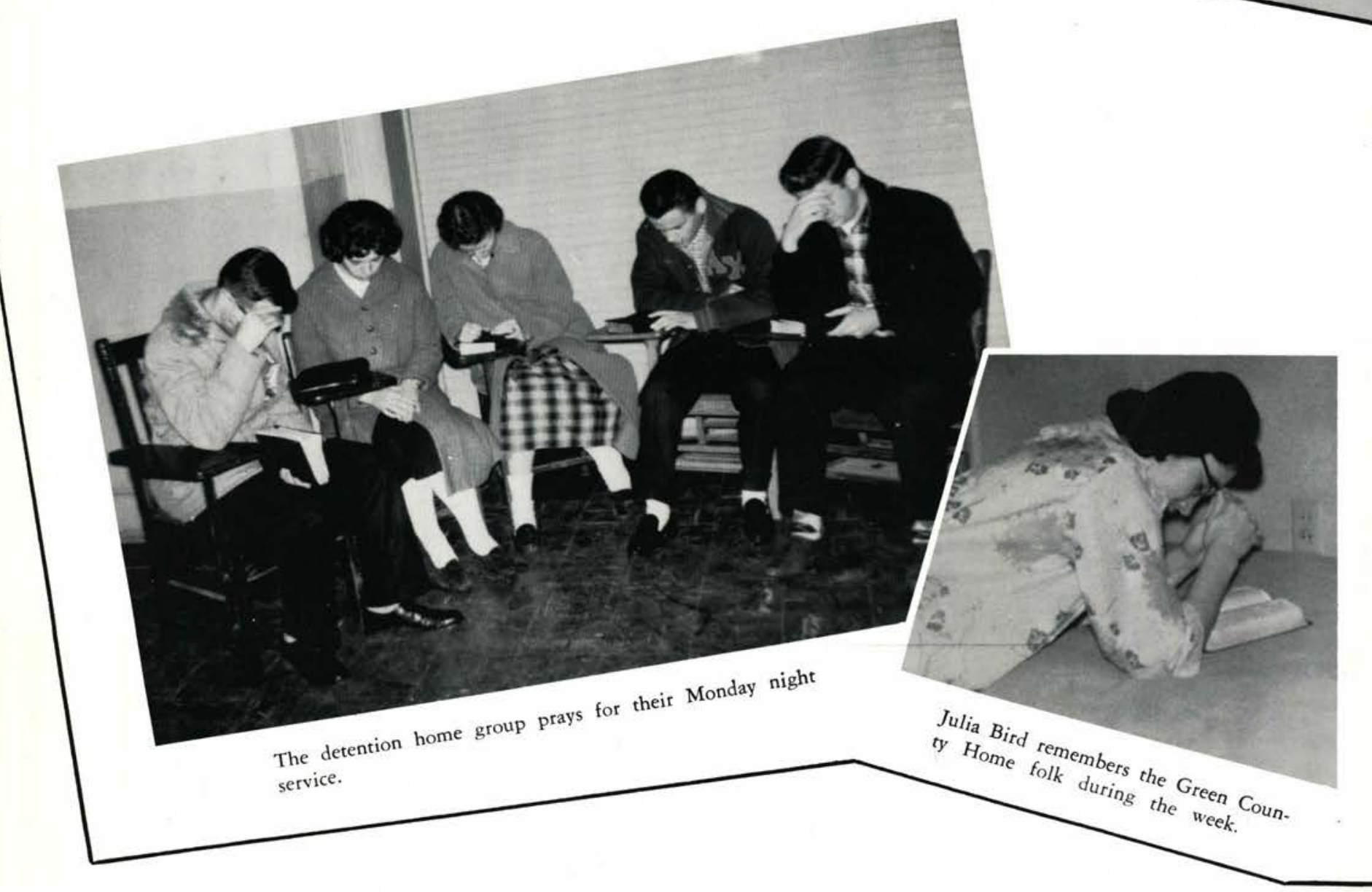


. Unto whom now I send thee, to open their eyes, and to turn them from darkness to light. Acts 26: 17-18

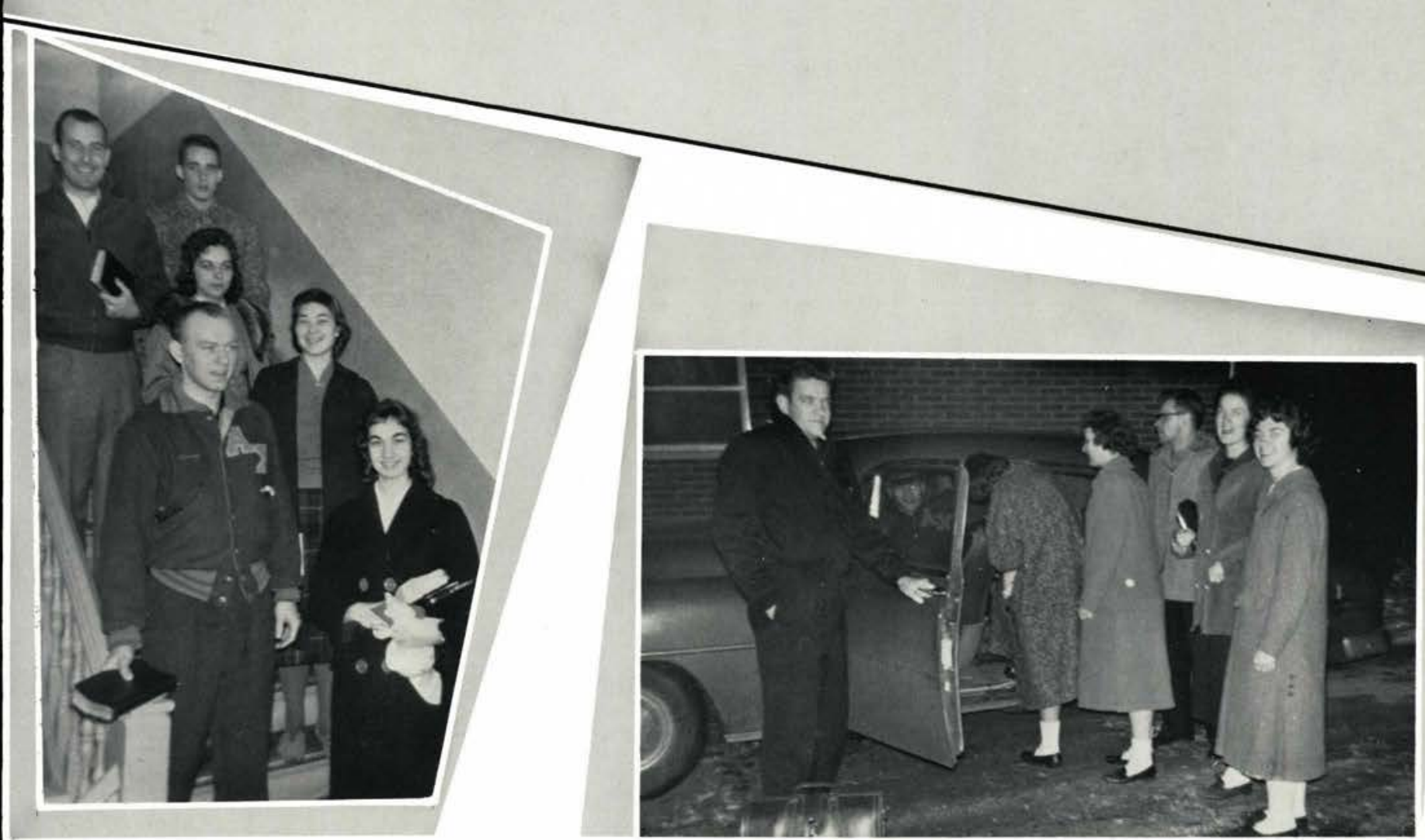




\section{Send the Light...}

\section{... to the old folk}
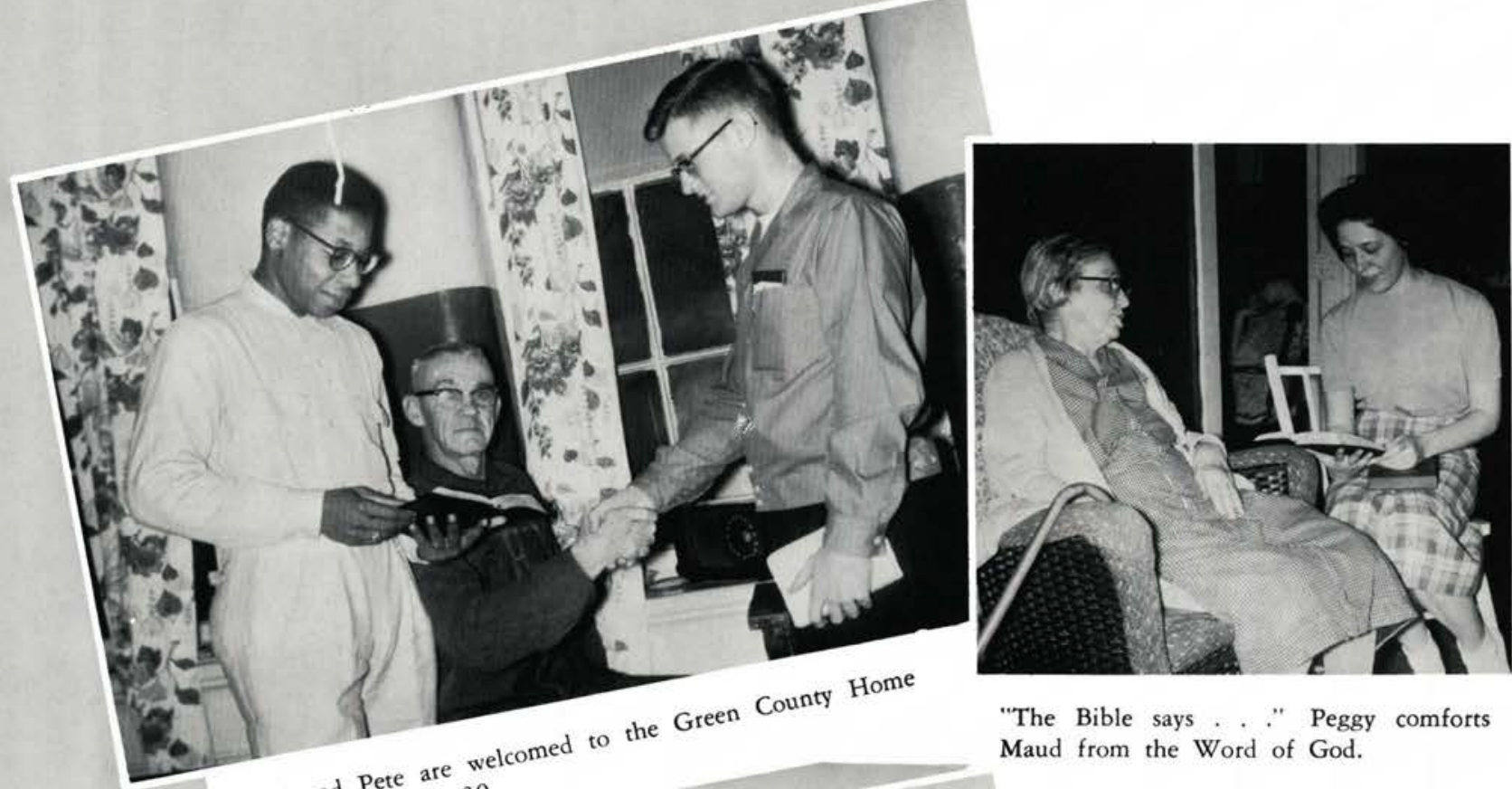

"The Bible says . . ." Peggy comforts Maud from the Word of God.

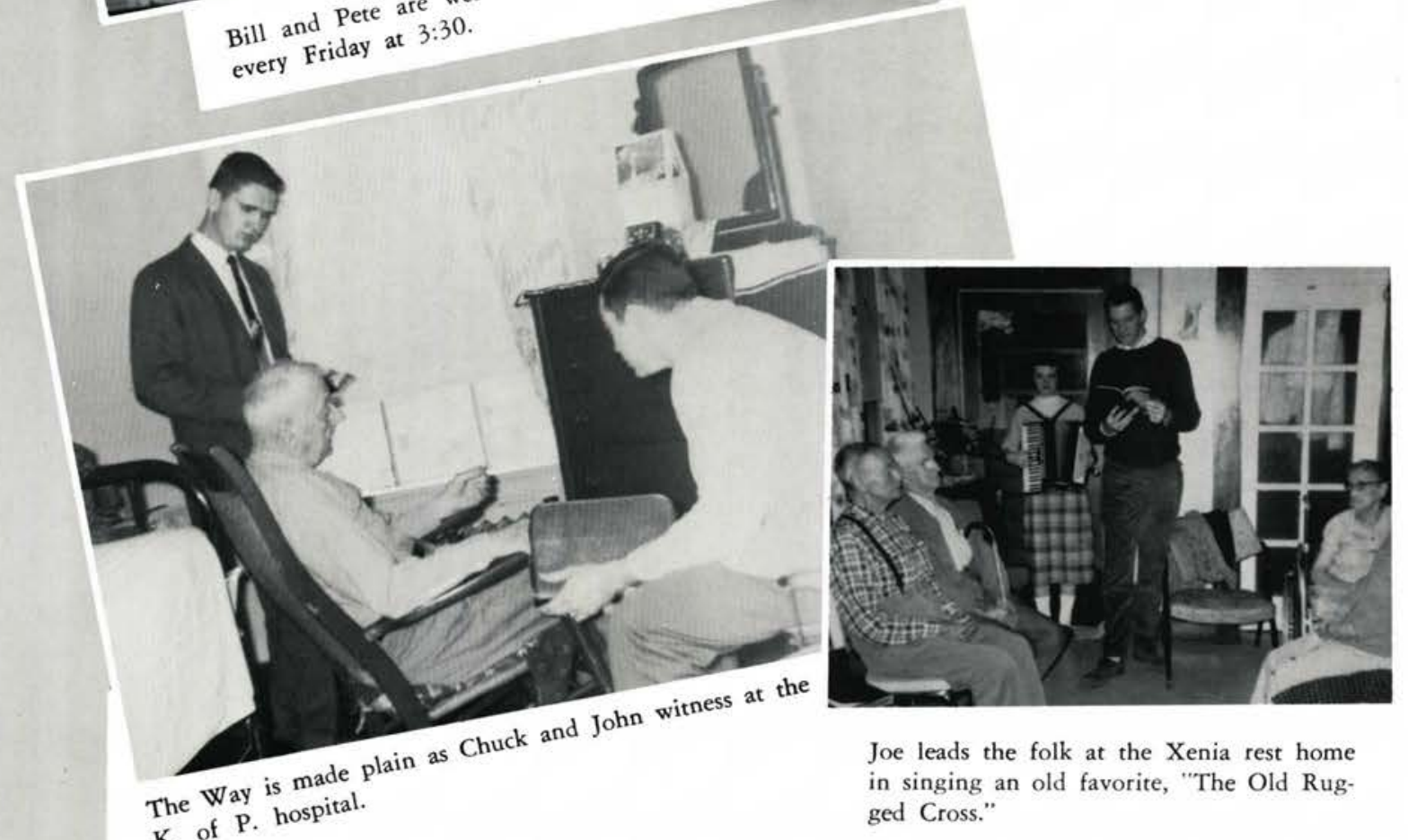


... to the youth
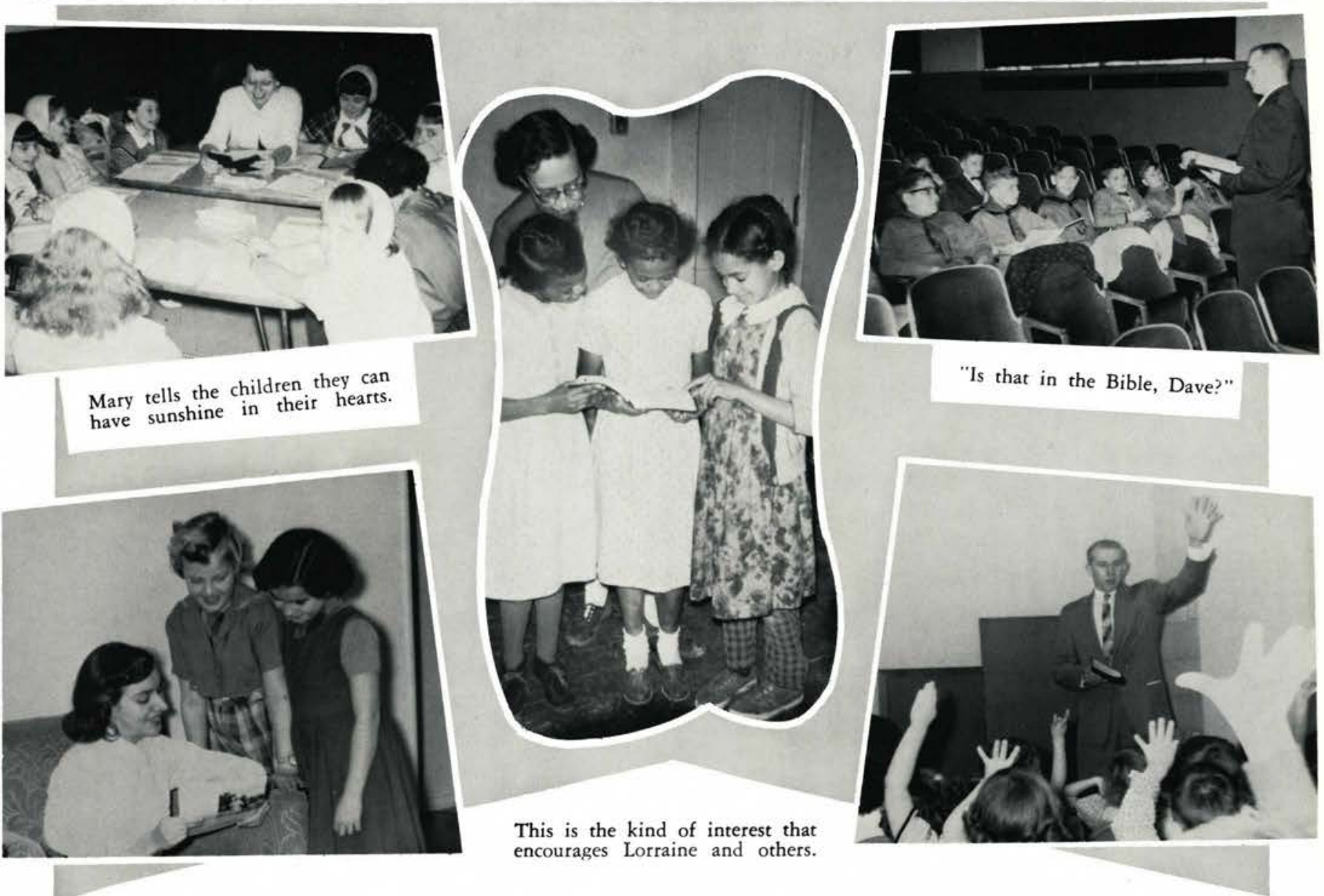

"Lucy, what story are you going to tell us today?"

\section{- - to many others}

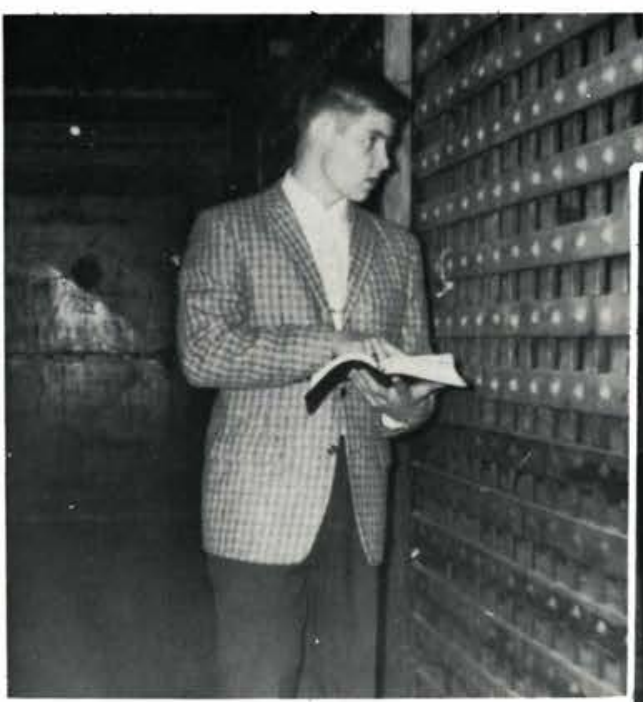

Gary brings a message of hope in Christ to those at Springfield Jail.
The detention home group discuss their problems

with the supervisor.

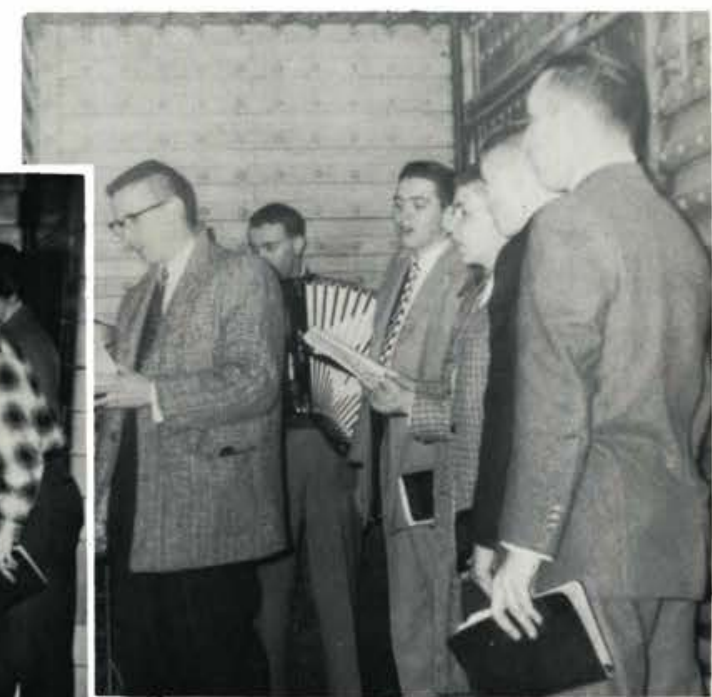

Familiar hymns soften hearts as the fellows open their service at Springfield Jail. 


\section{. . in different ways}

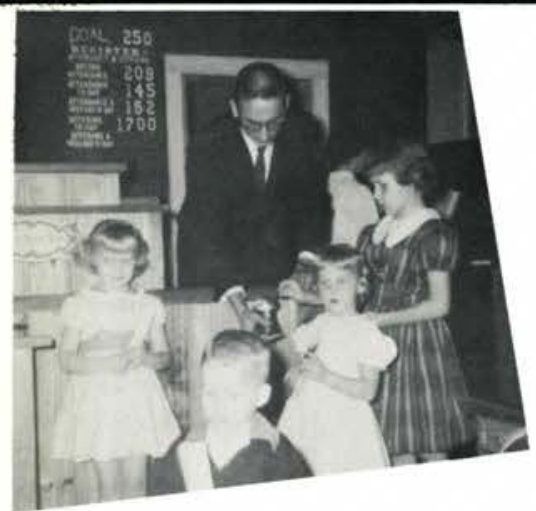

Dave, Sunday School Superintendent at Immanuel finds real joy as children give their birthday offering.

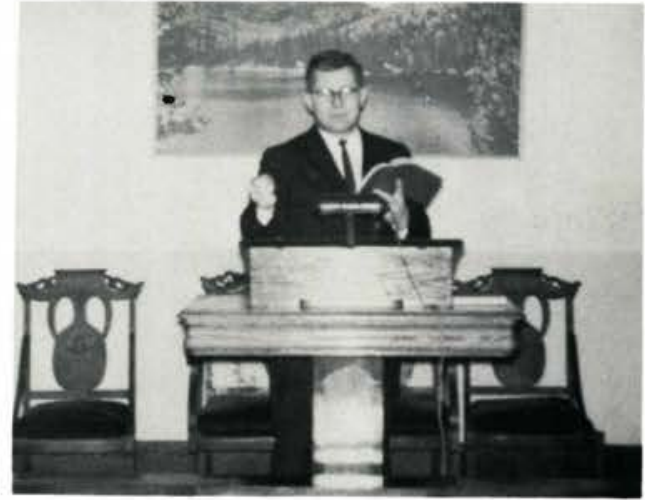

Bob preaches and teaches the Word of God as a student pastor at Belle Center, Ohio.

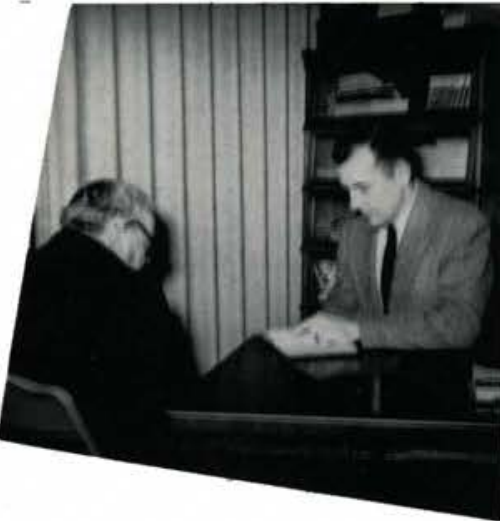

As Religious Director, Ray is a sympathetic counselor at the Cincinatti City Gospel Mission.

\section{.. to other lands}

As each assignment is performed we cannot keep from thinking of what lies ahead of this preparation. And even though the future may seem like a hazy cloud to us, and the present may appear to be a blurred picture, there remains the assurance of Scripture: "I will never leave thee nor forsake thee."

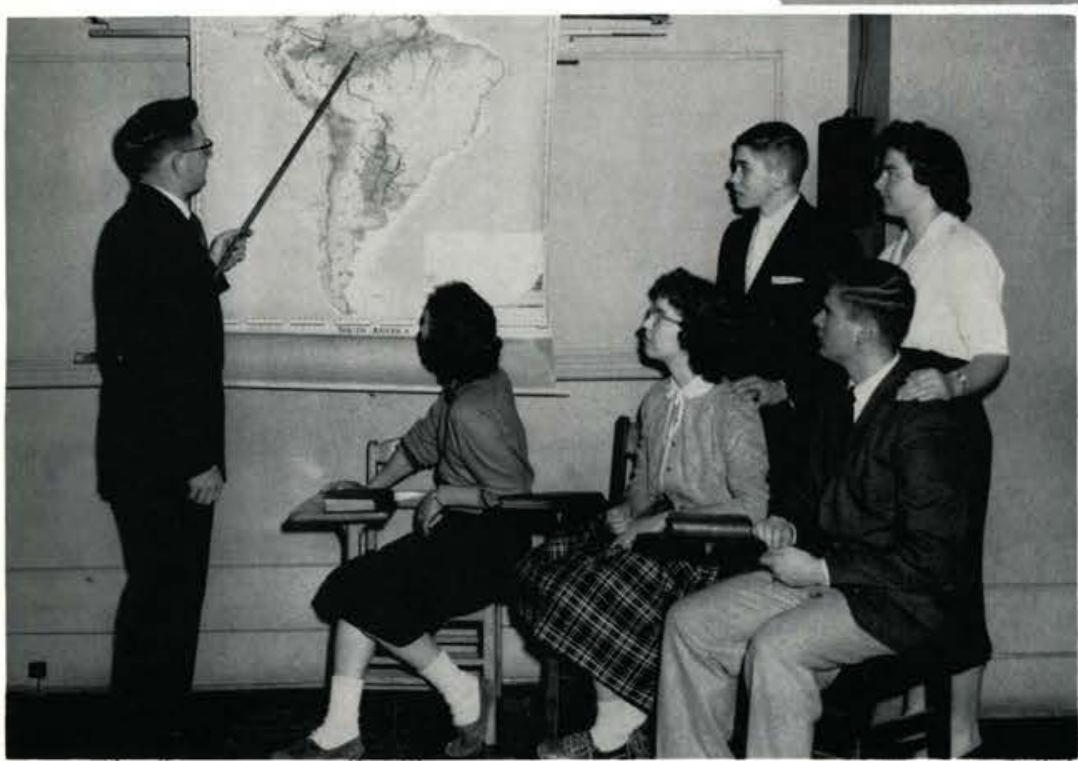




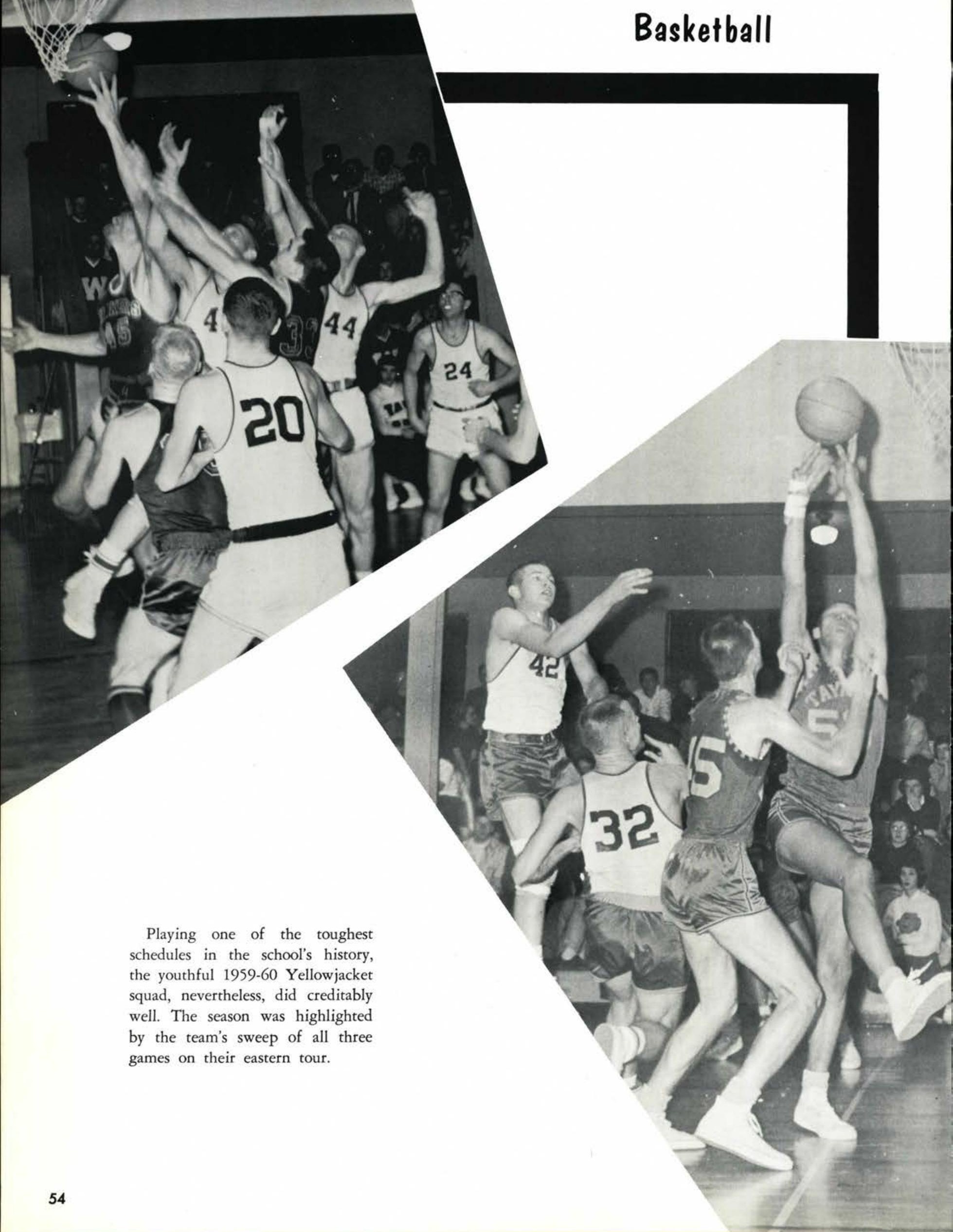




\section{The Varsity}

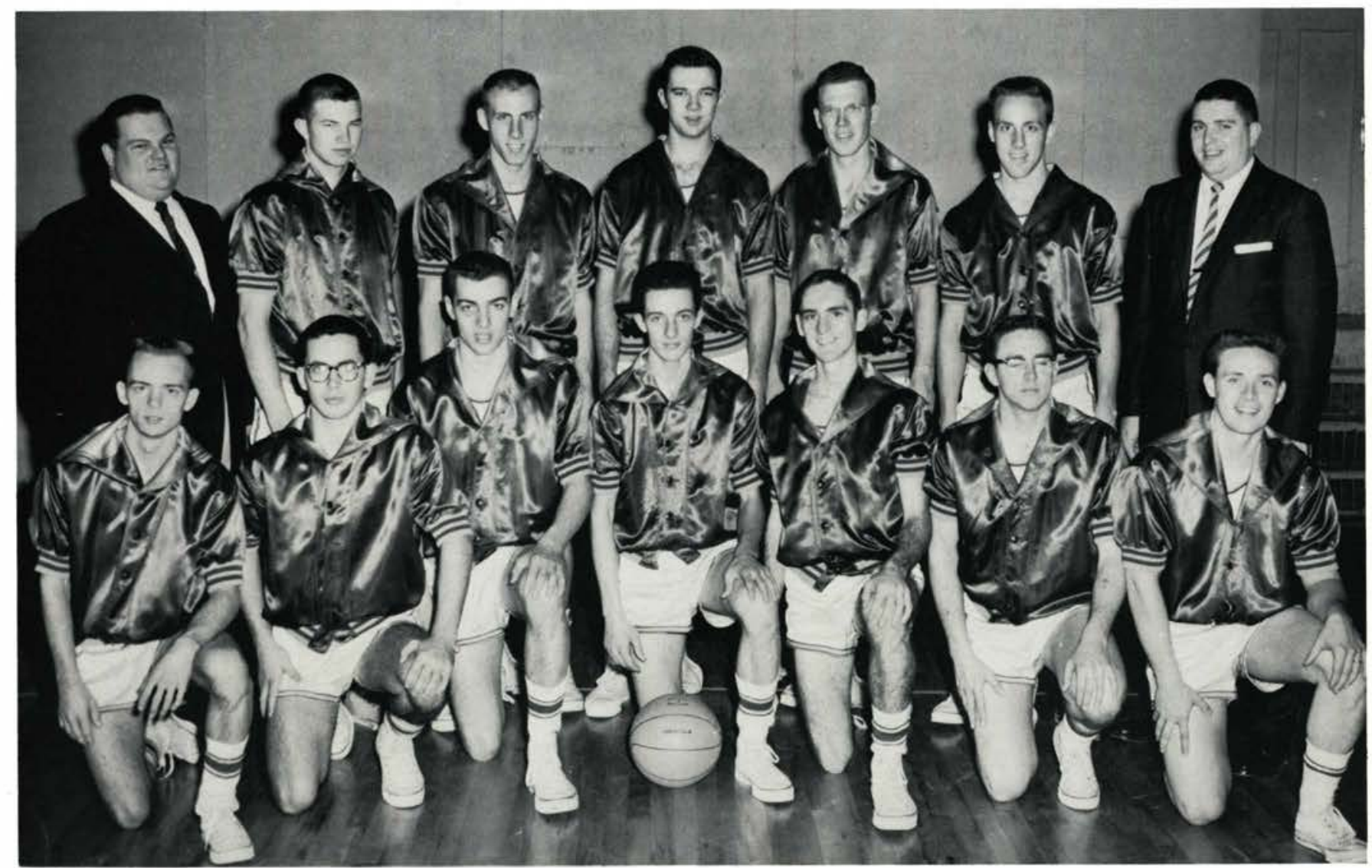

Front Row: Ted Ocheltree, Bill Elder, Dave Jeremiah, Norris Smith, Sam Canine, Terry Zerby, Dave Lewis. Back Row: Tony Kilbourn, Manager; Pete Reese, John Entner, Jack Moffat, John Butler, Jim Entner, Mr. Bowser, Coach.

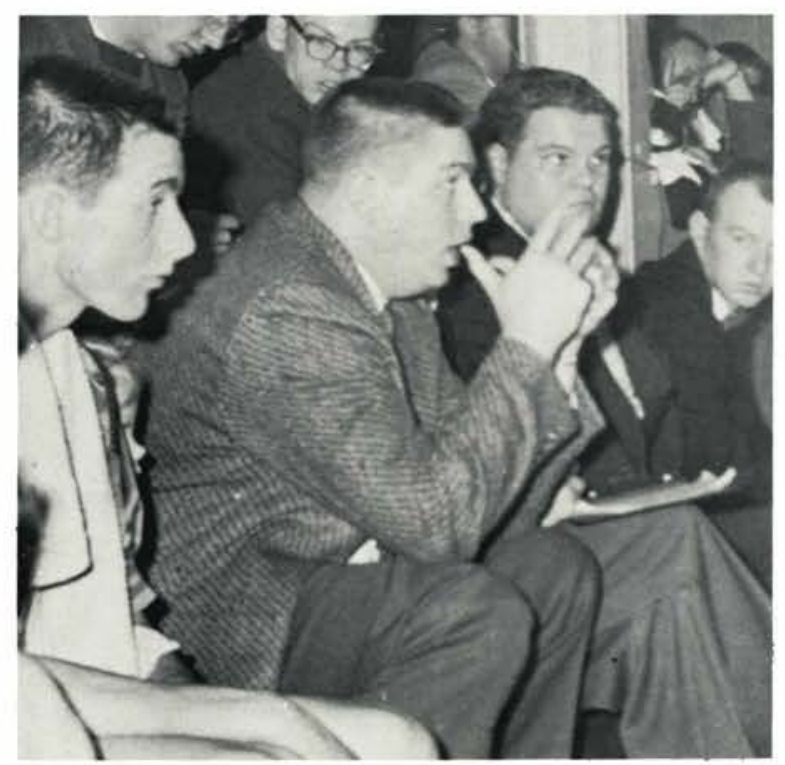

Coach Bowser watches intently as ...

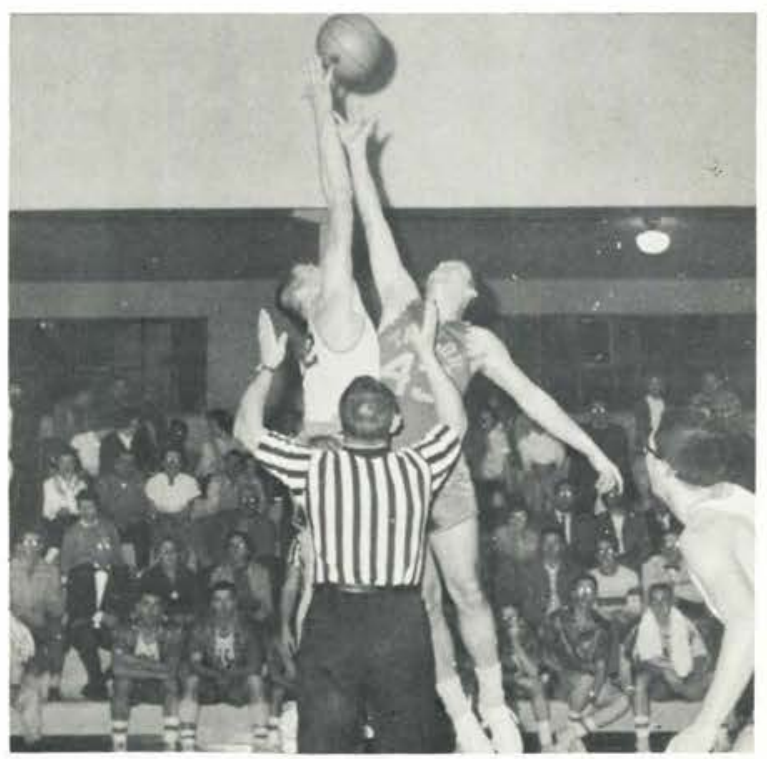

... Pete Reese gets the jump on a Taylor opponent. 

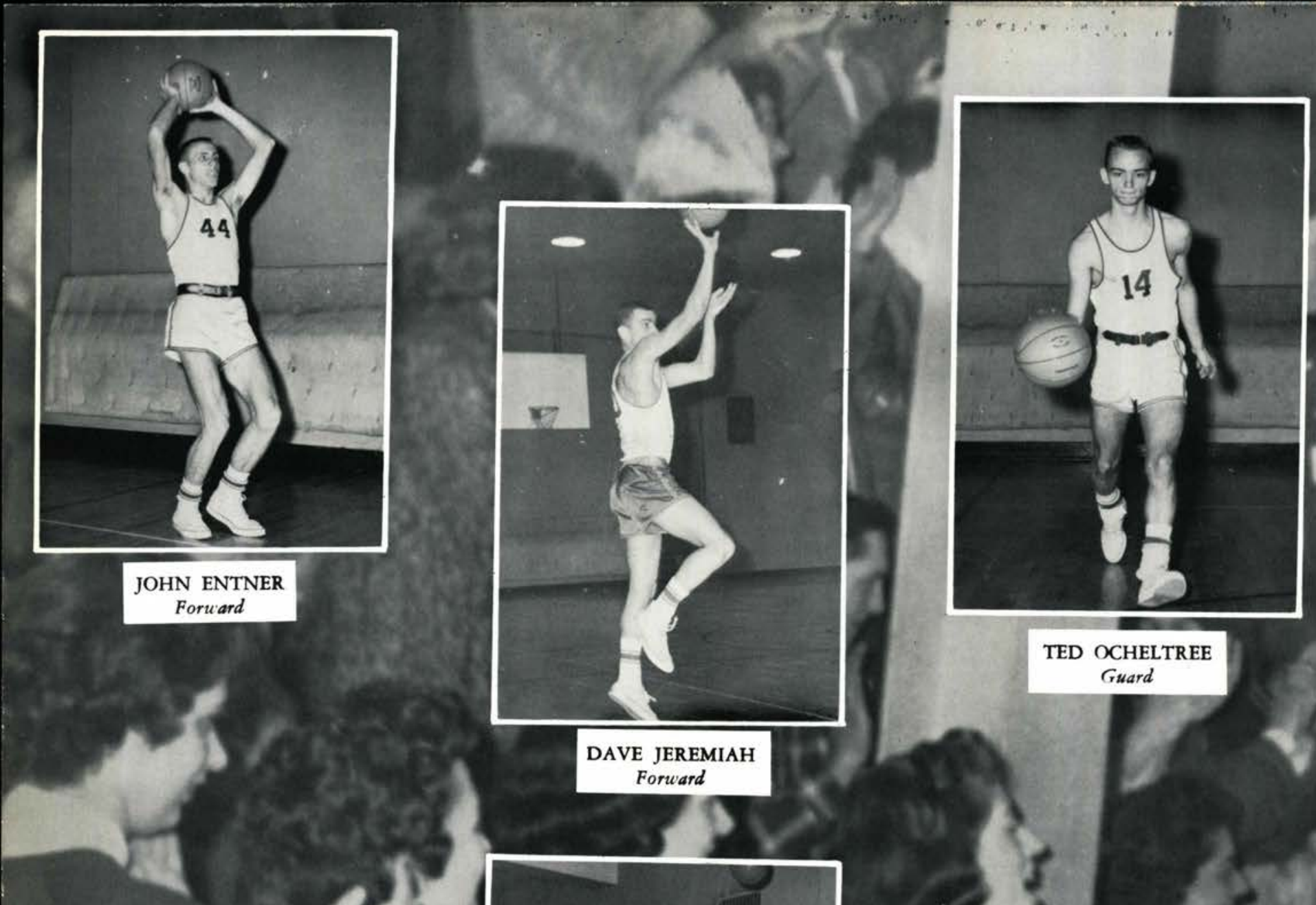

$$
\text { Forward }
$$

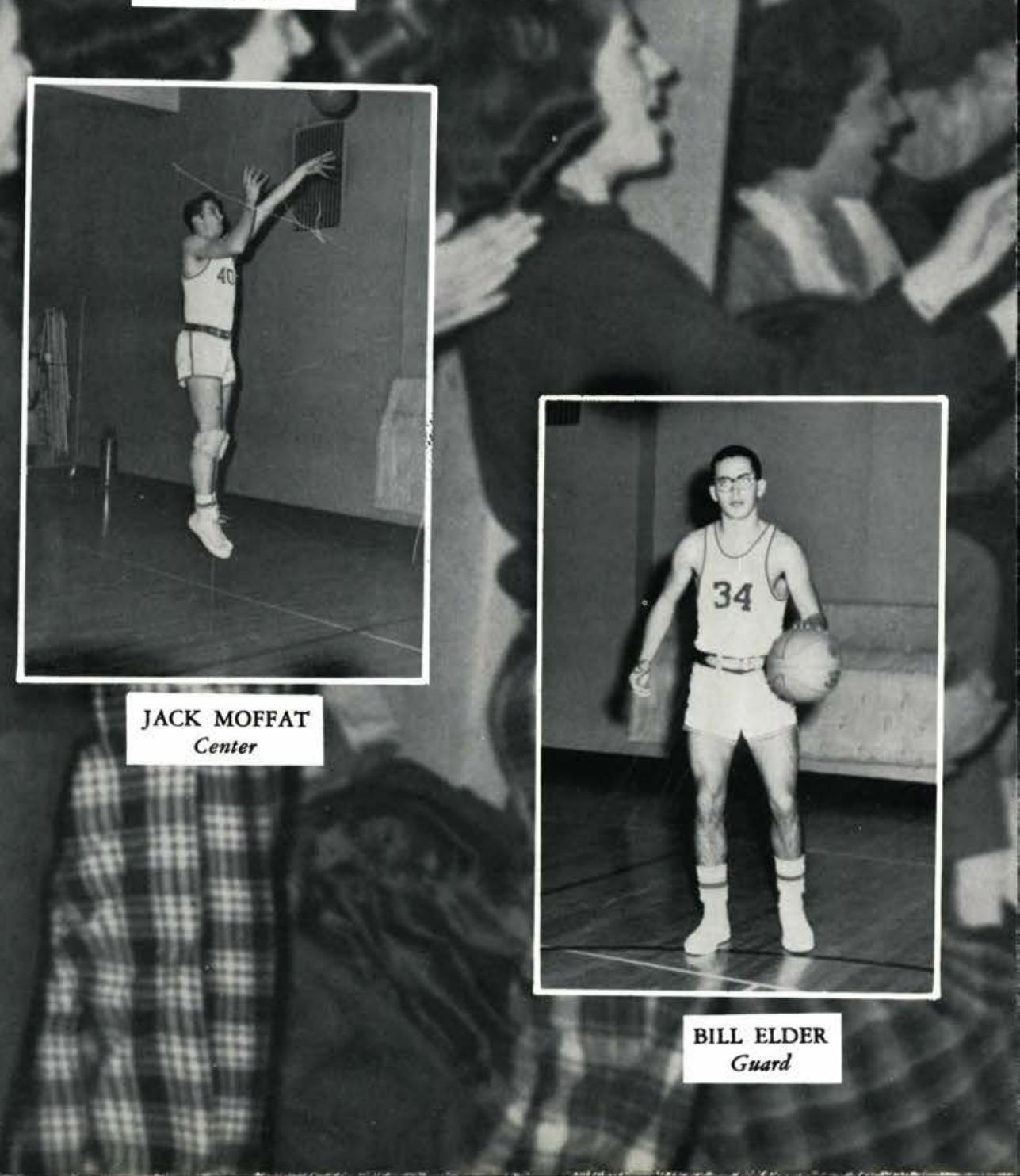

\section{NORRIS SMITH}

Guard 


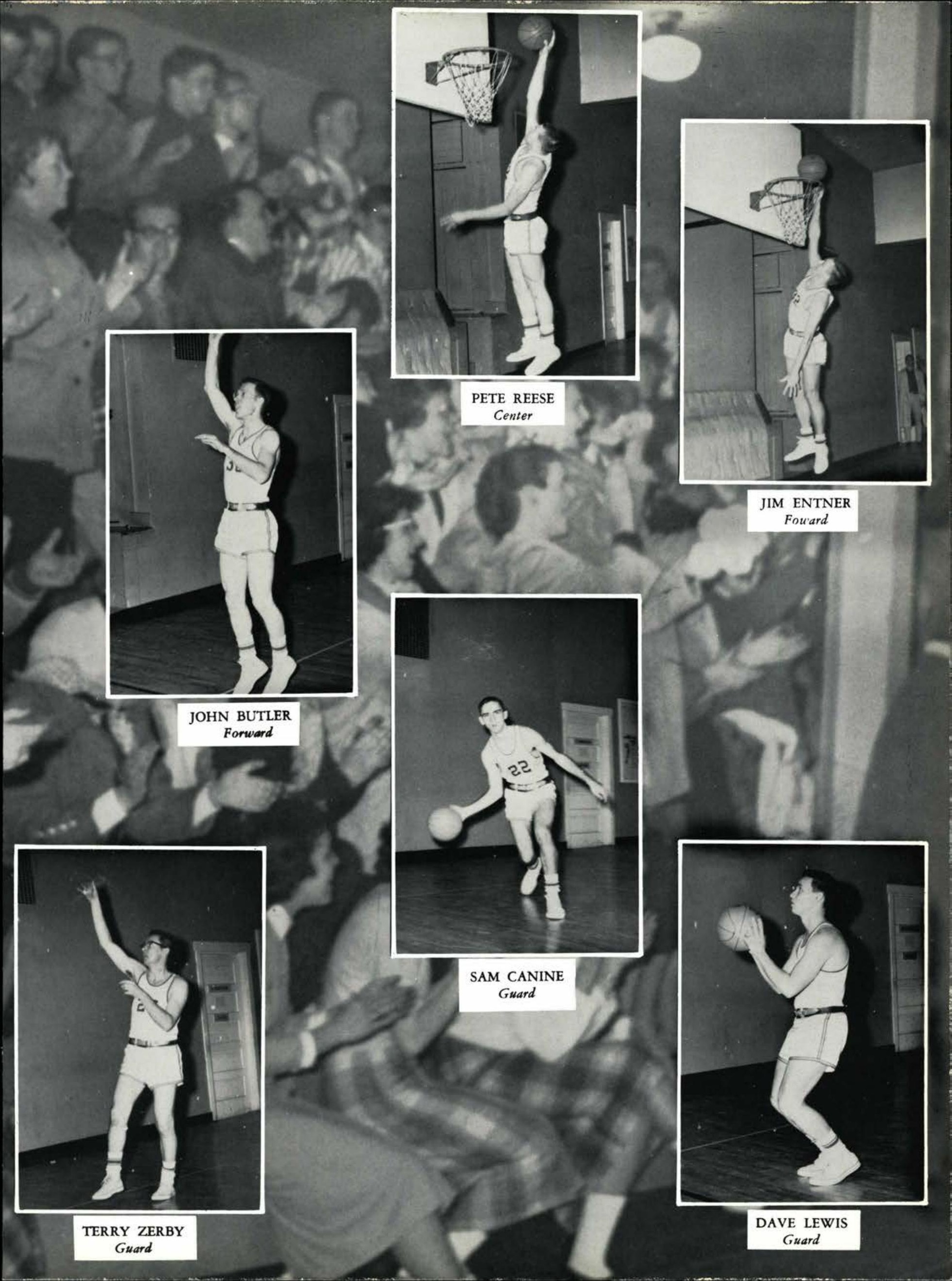




\section{Varsity Record}

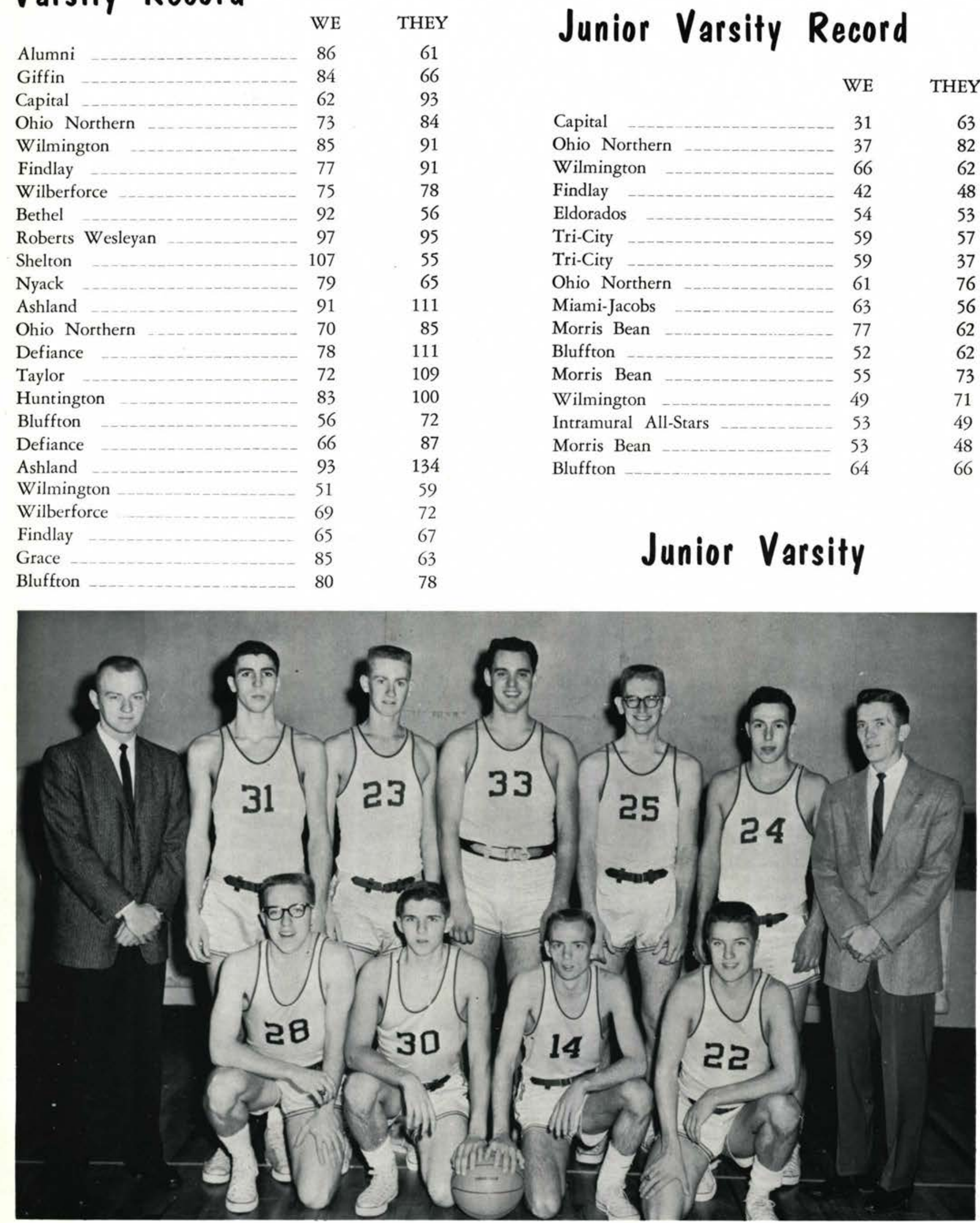

Front Row: Ed Eastman, Rodney Bissel, Ted Ocheltree, Lynn Jefson. Back Row: Terry Goodrich, Manager; Mike Neally, Royce Caplinger,. Phil Brower, Vance Ashley, Bill Wolf, Mr. Thompson, Coach. 


\section{Varsity}

\section{Cheerleaders}

Left to Right: Carol Zoellner, Pat Petry, Esther Weiss,

Sandy Hammerstrom, Rosemary Smith. Front: Pattic Neely.

Cedarville is noted for its enthusiasm manifested at basketball games. Here, the girls wearing their new outfits lead in "FIGHT Locomotive," a new cheer.

\section{Junior Varsity}

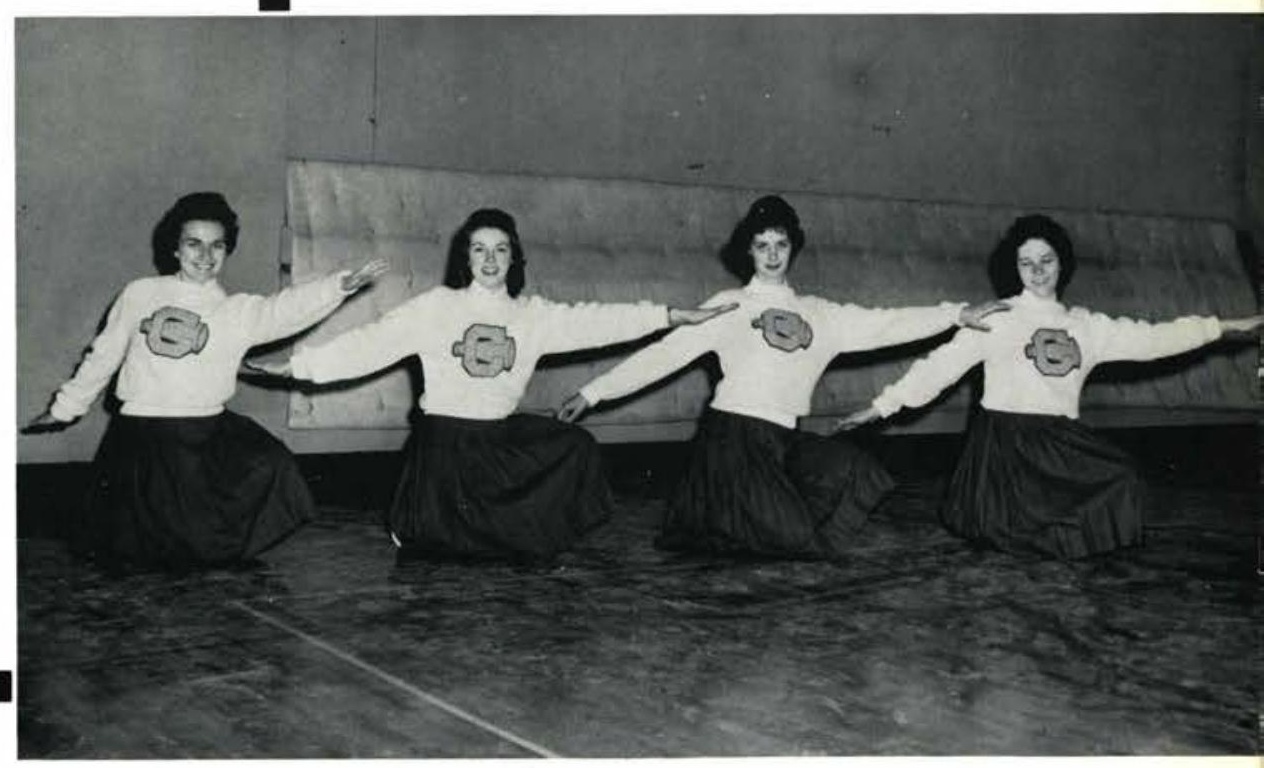

Left to Right: Gail Carter, June Golden, Flo Cannon,

Peggy Buerer. 


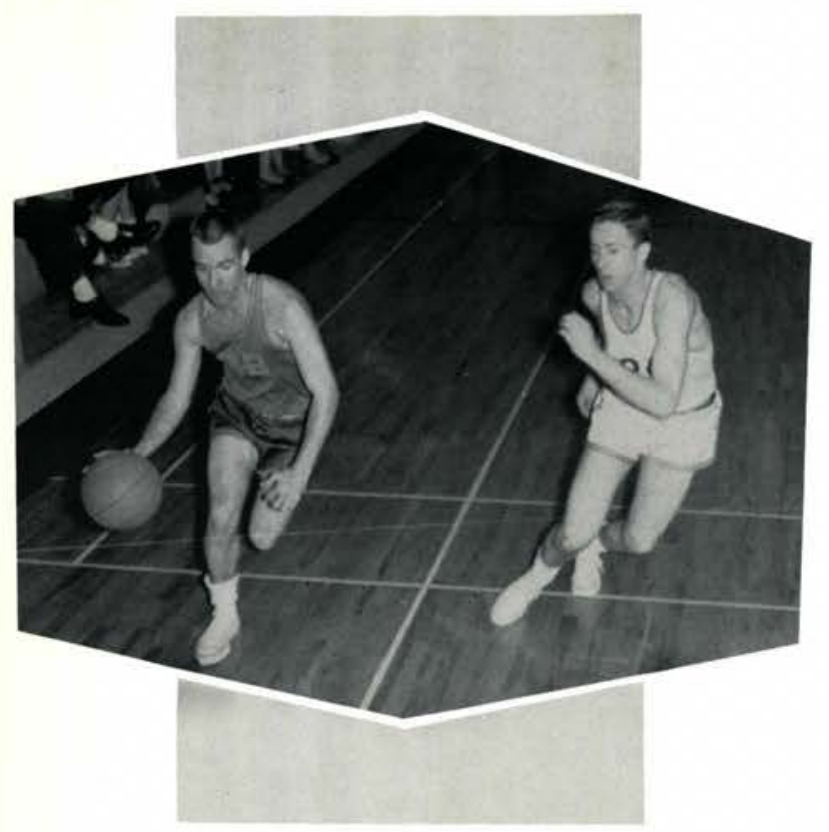

\section{ALUMNI GAME}

The alumni once again bowed to defeat to the varsity basketball team on February 21 in their annual game climaxing the 1959 basketball season.
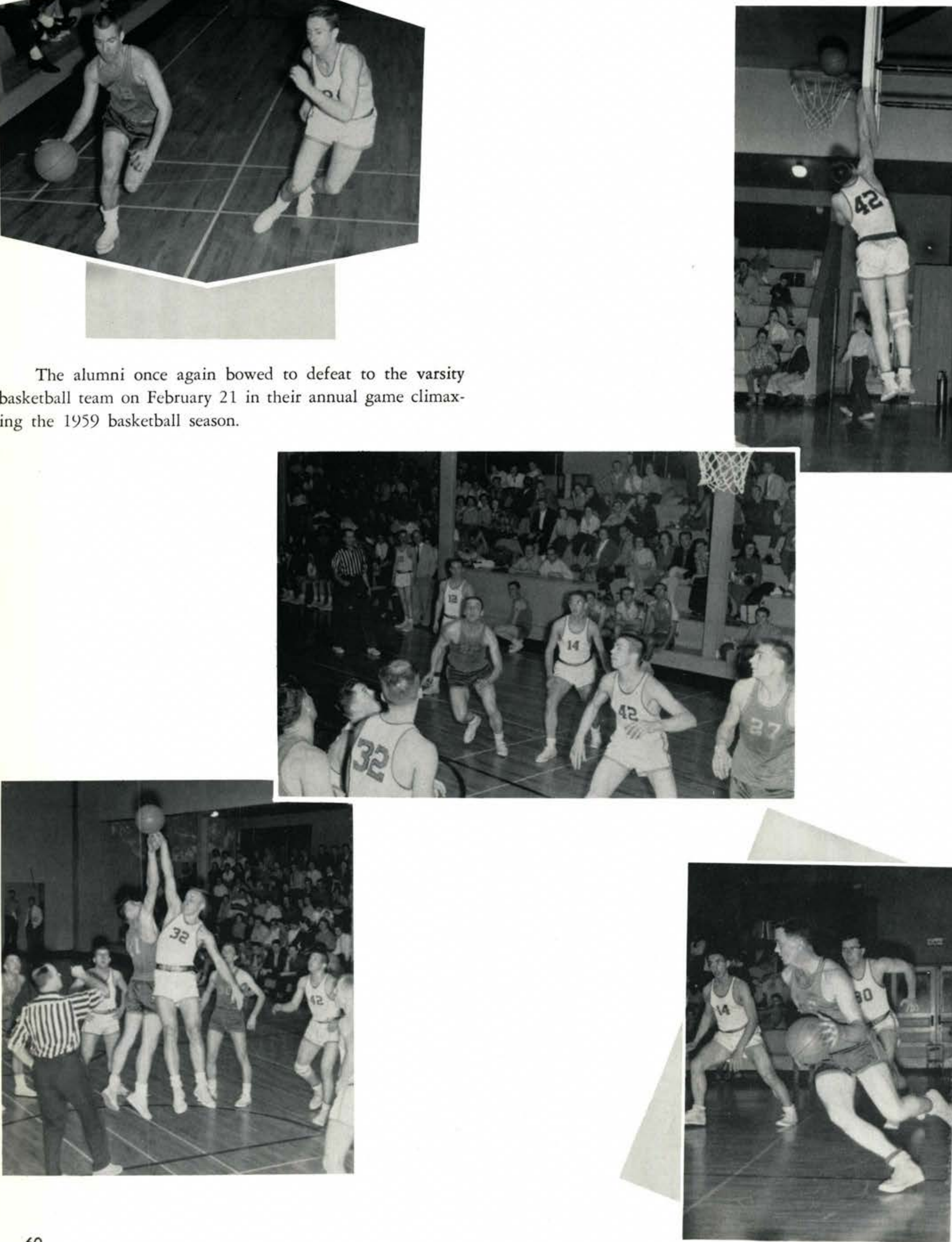


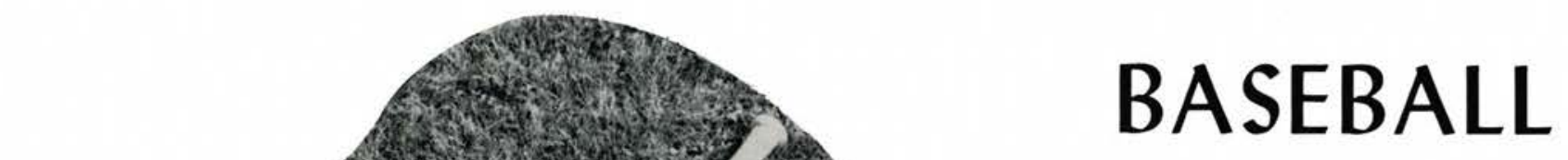

Although the season was not too successful in the won-lost column, the team proved to be one of potential when they defeated both Ohio Northern University and Wilmington College. They developed steadily under the watchful eye of Coach Bowser.

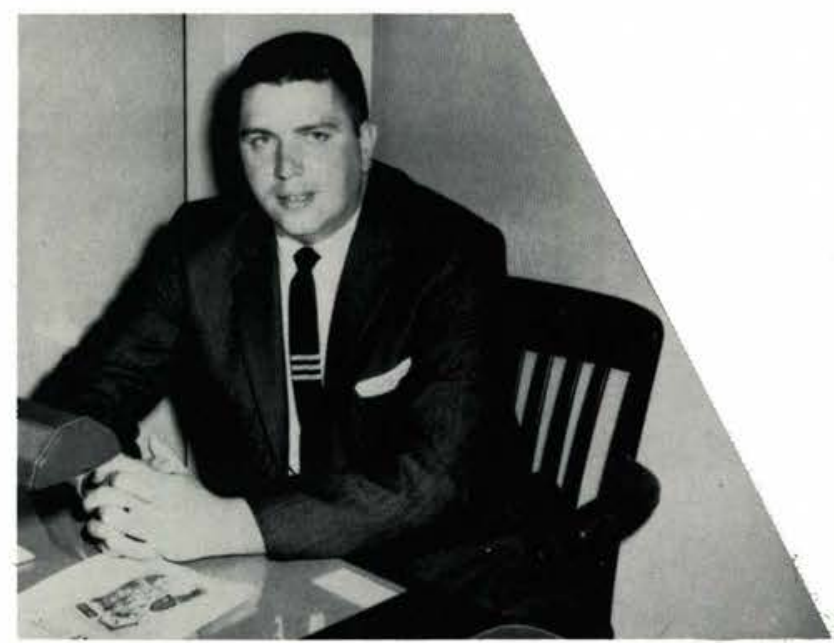

Coach Bowser

The Team



Front Row: Chuck Taylor, Otis Stone, Ken Pycraft, Bob Humphreys, Dave Dautel, Marvin McCaslin. Back Row: Bogle Standifer, Merlin Ager, Vance Ashley, Roy Carr, Jim Entner, Dave Earnhart, Gary Luscombe, Coach Bowser. 

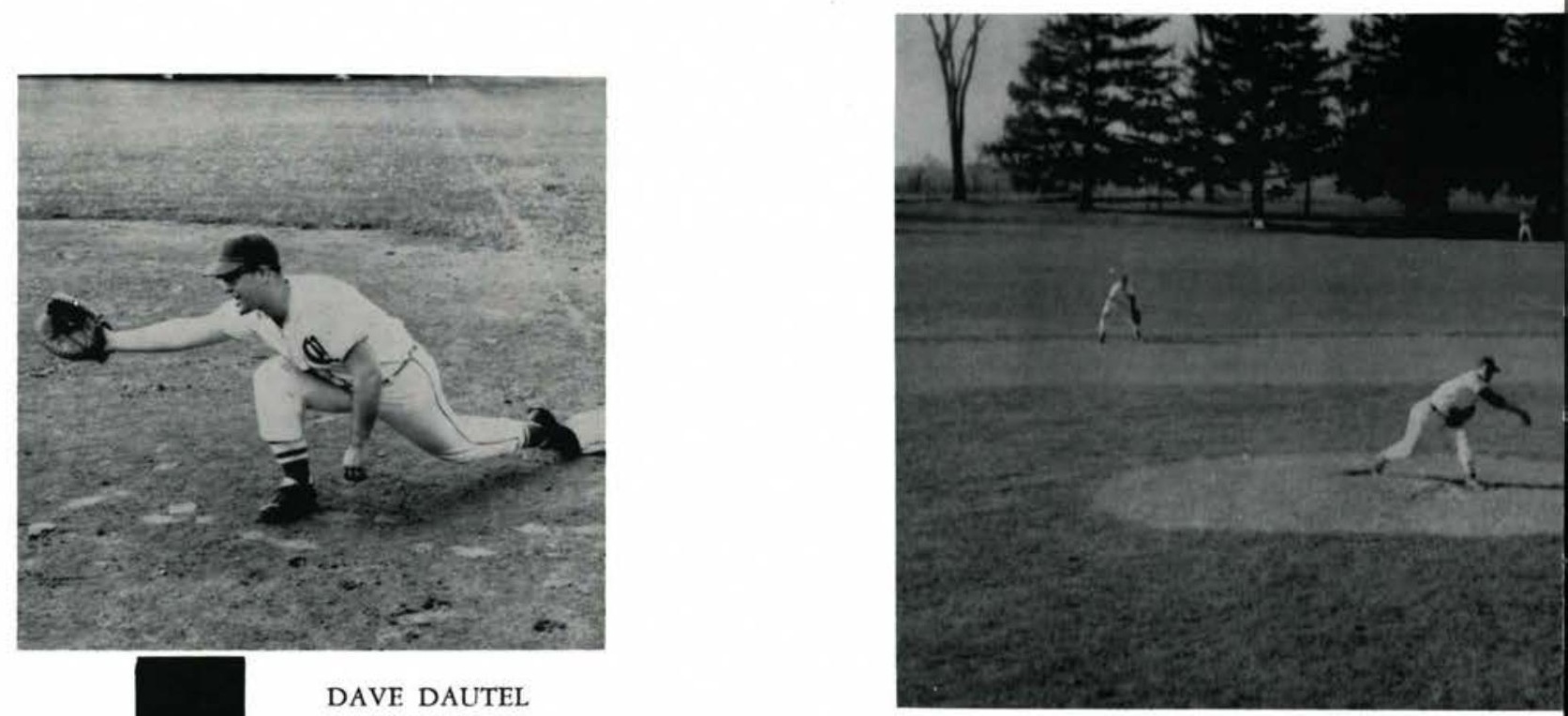

DAVE DAUTEL

First Base

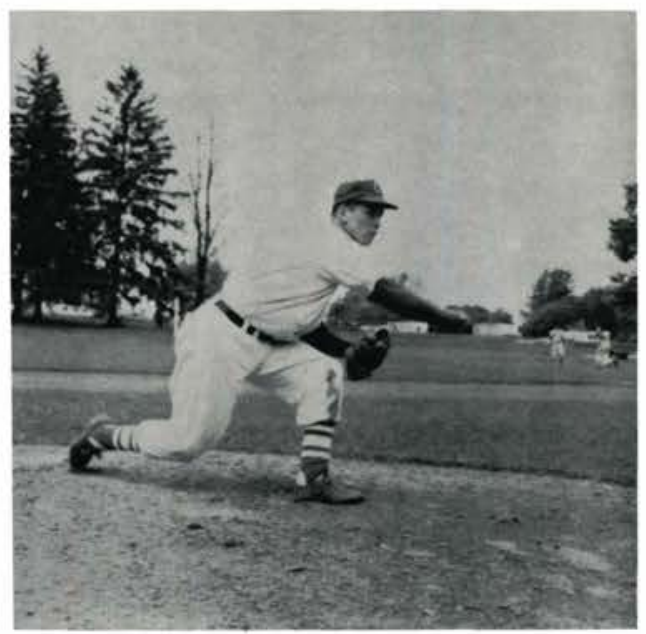

MERLIN AGER

Pitcher

Most Valuable Player

CHUCK TAYLOR

Left Field

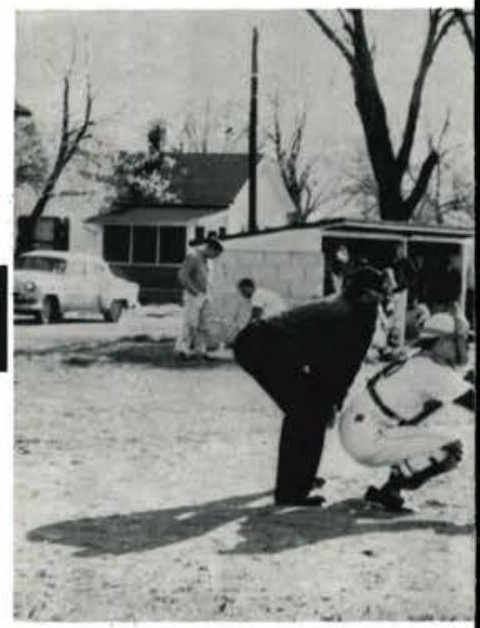



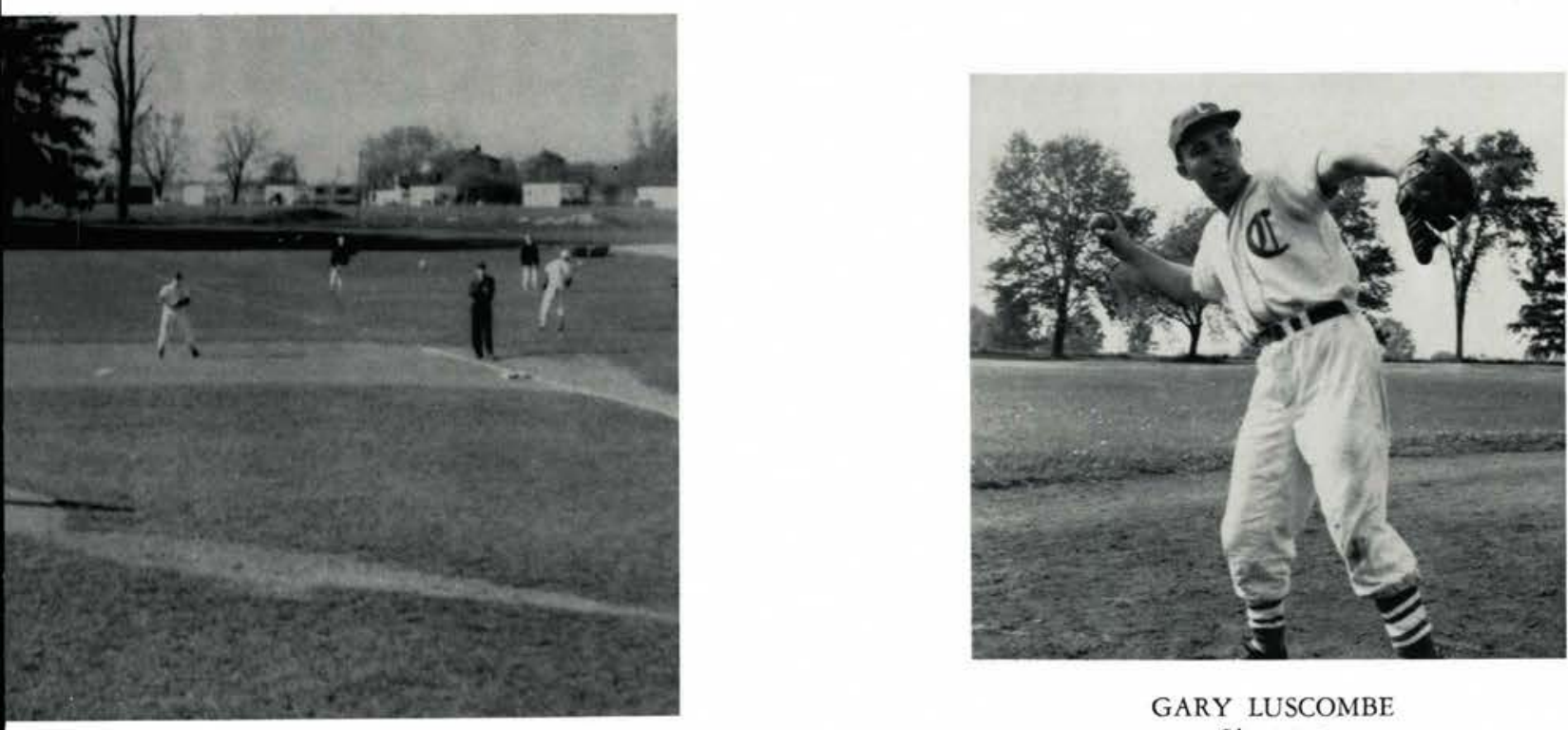

GARY LUSCOMBE

Sbortstop

VANCE ASHLEY

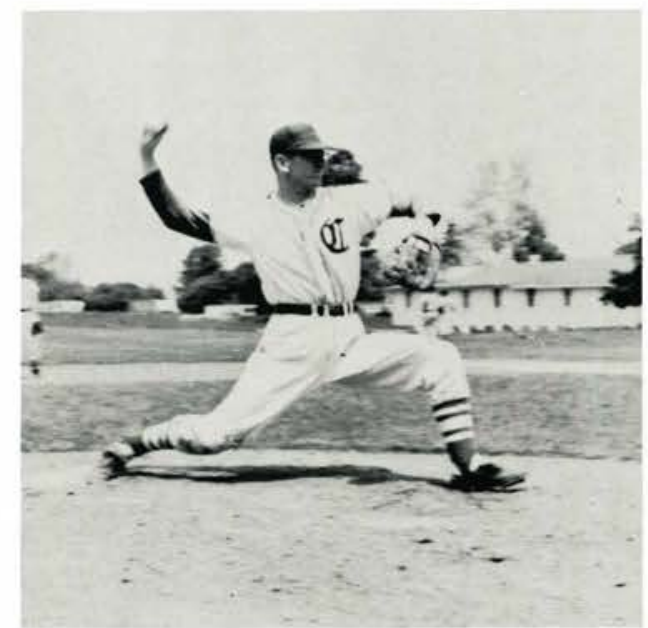

Pitcher
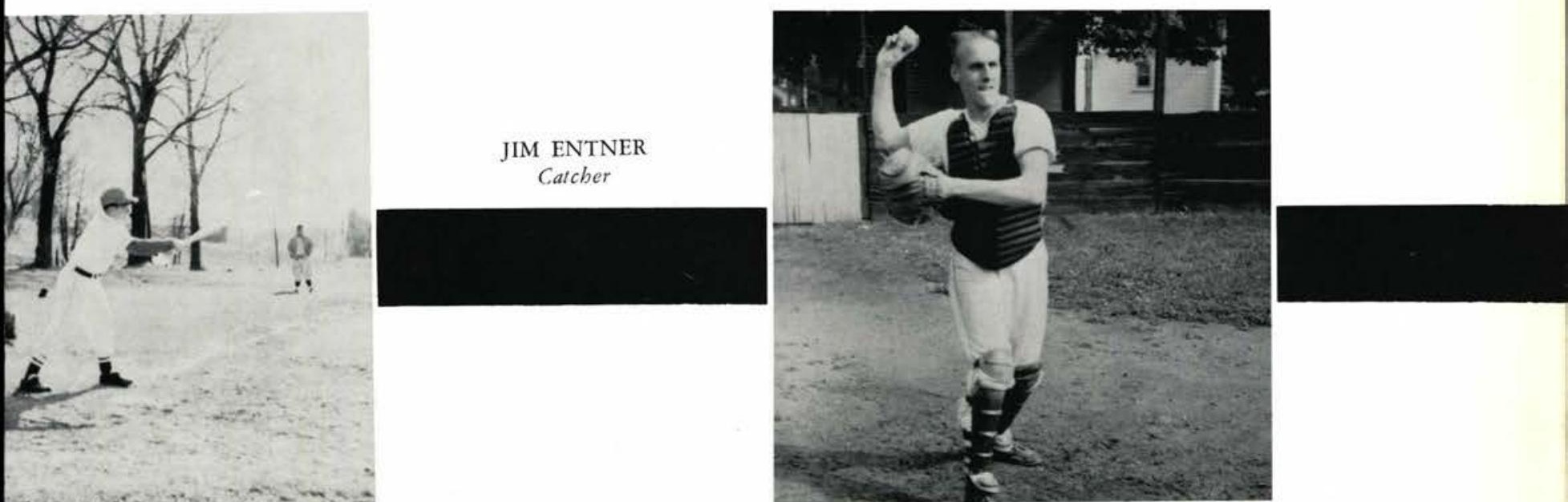

A

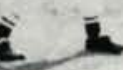

에는 $=$

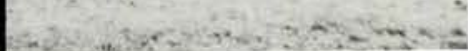




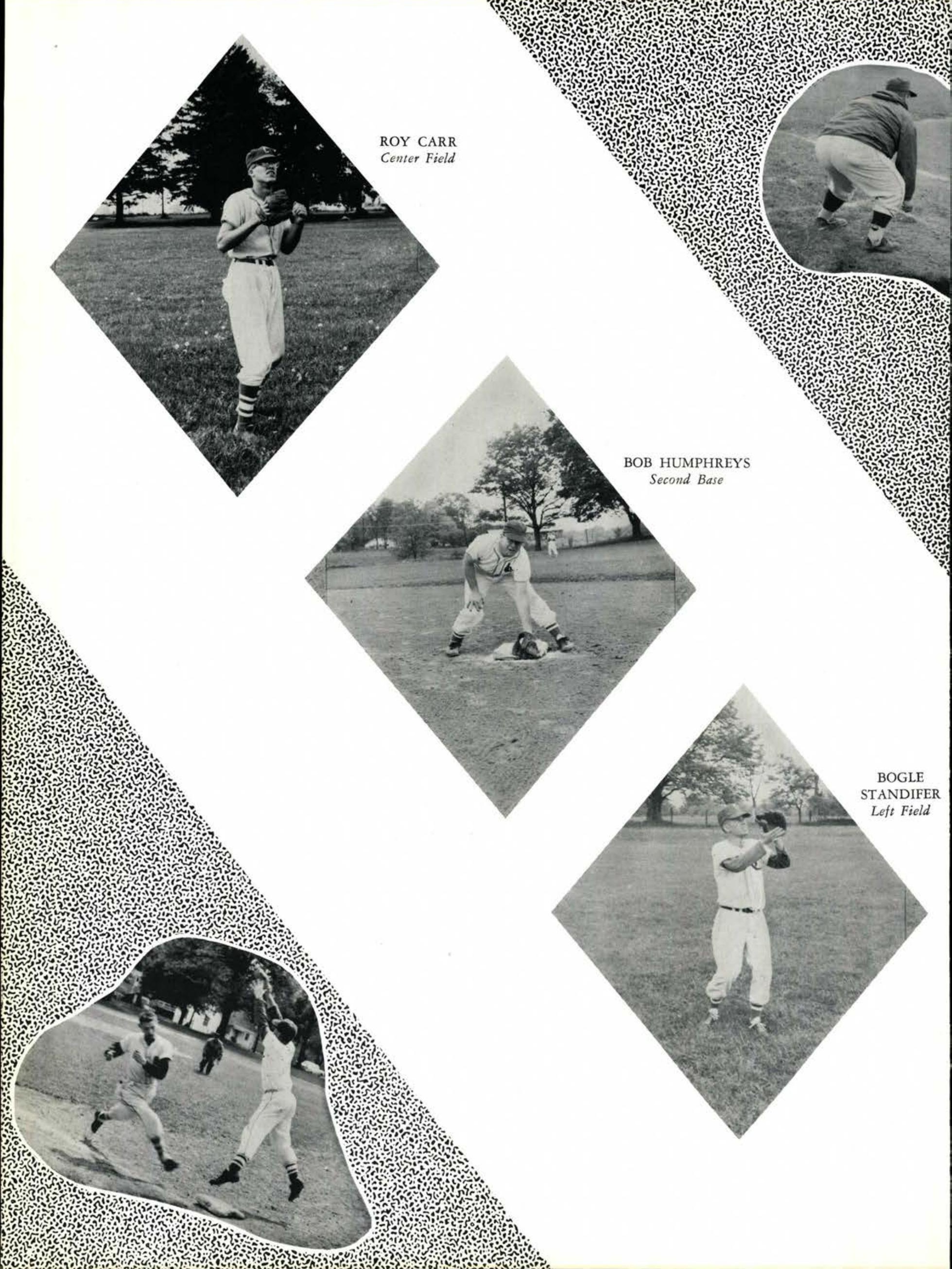


OE

N

S

N

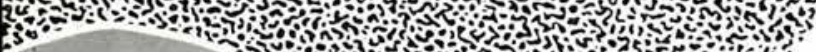

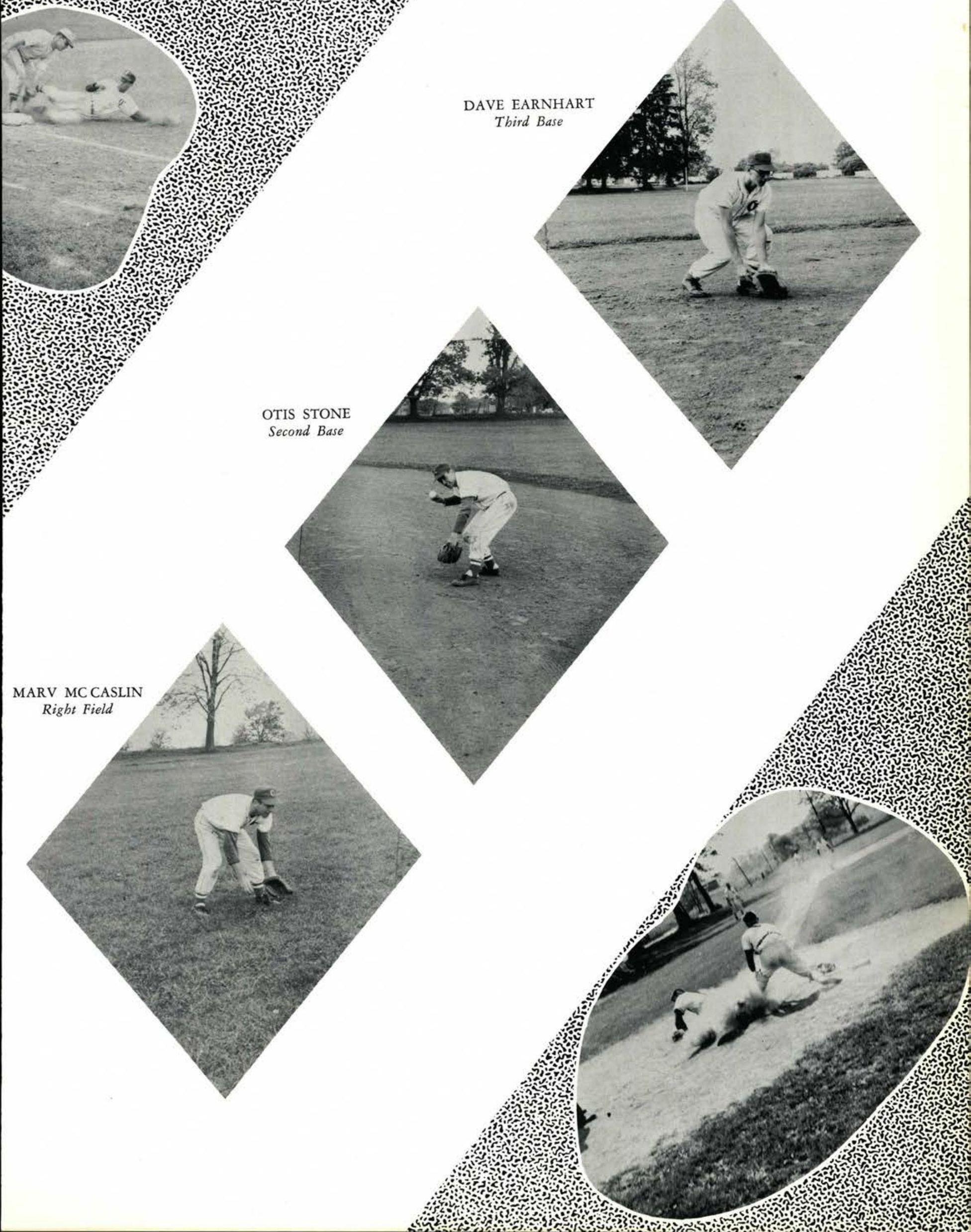

on

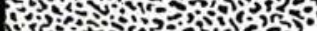

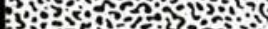

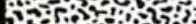

in?

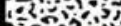

(1)

MARV MC CASLIN

Right Field 


\section{Social Highlights}

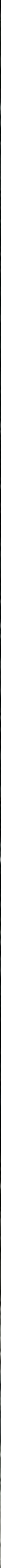




\section{School Picnic}

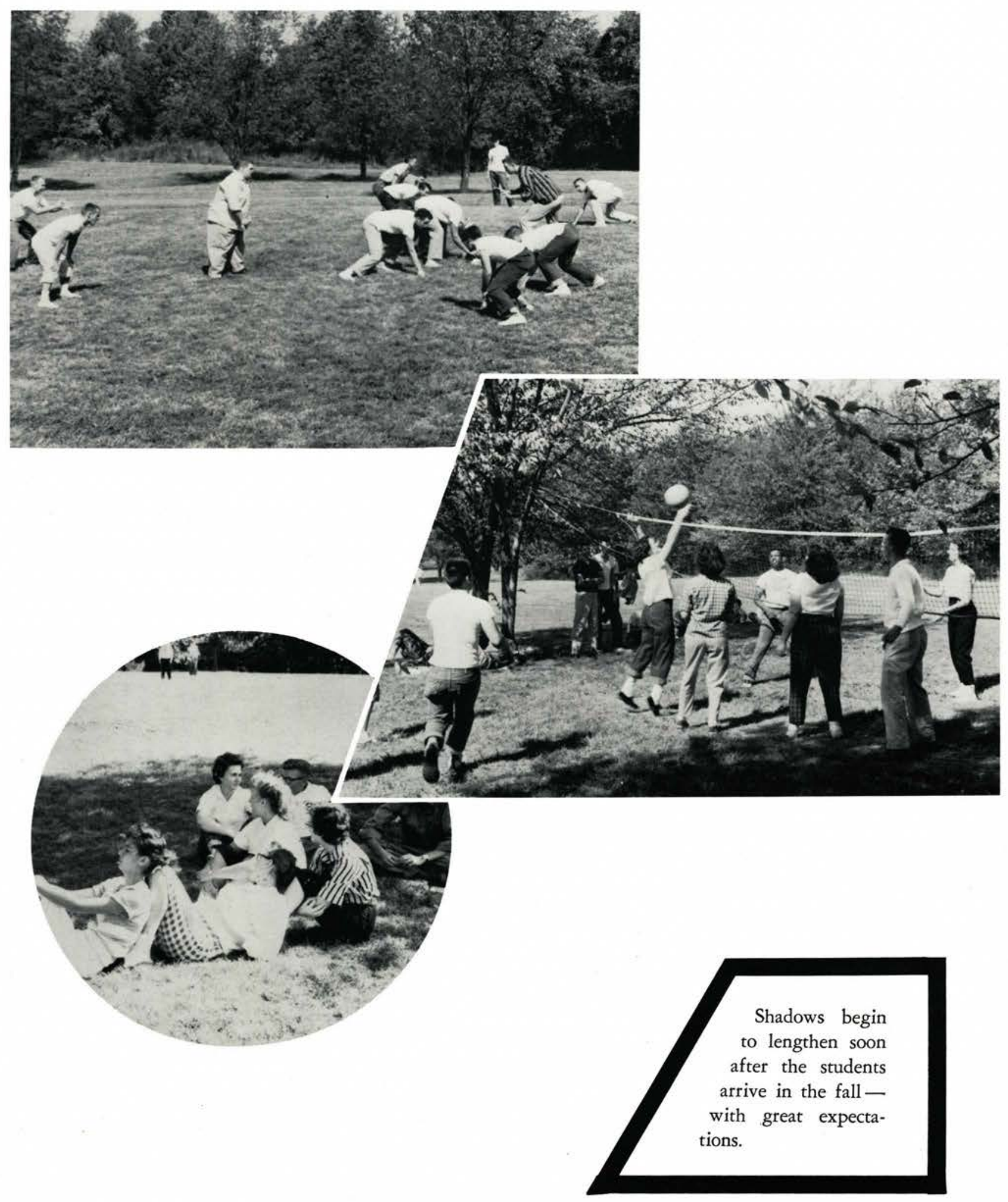




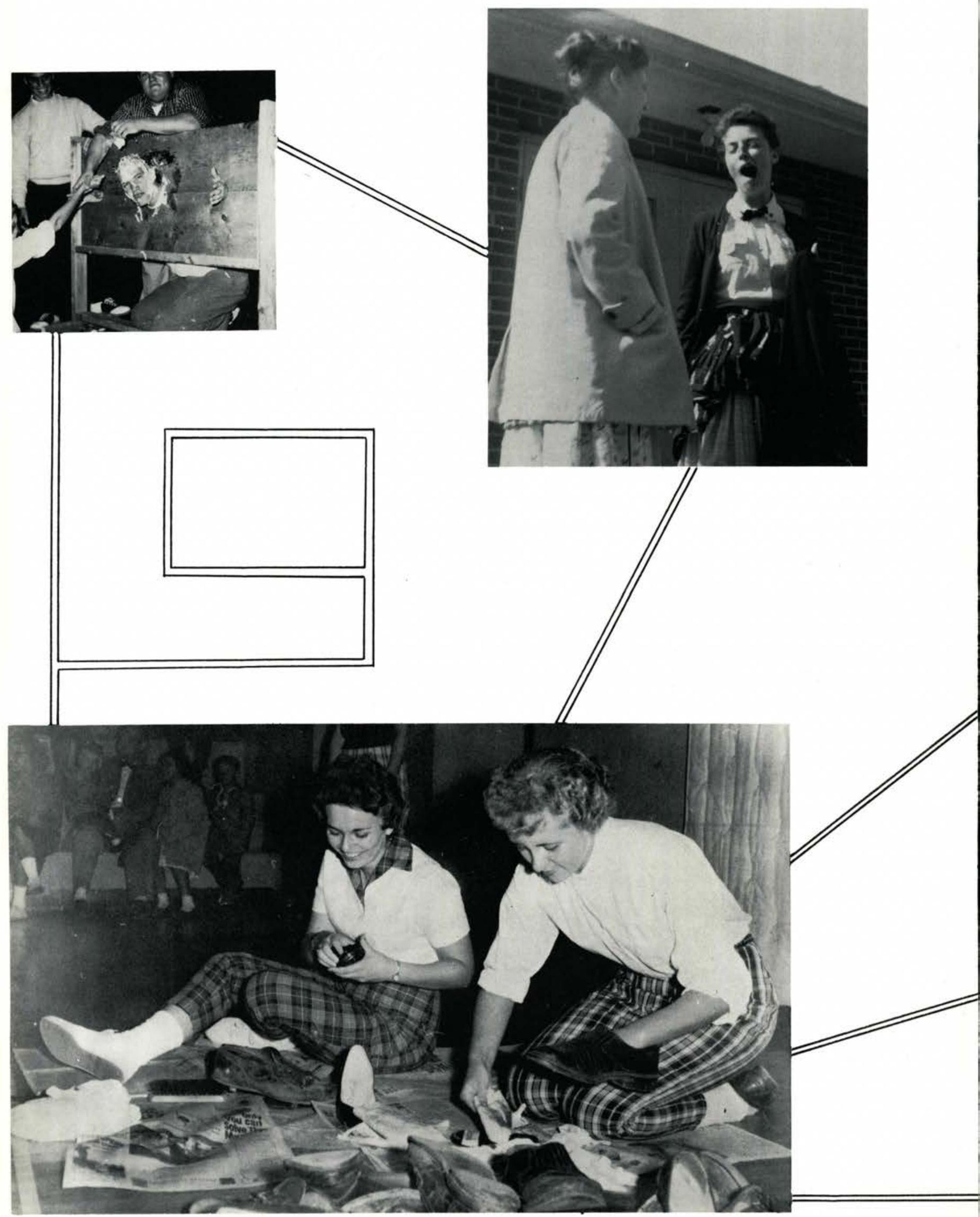




\section{Freshman}

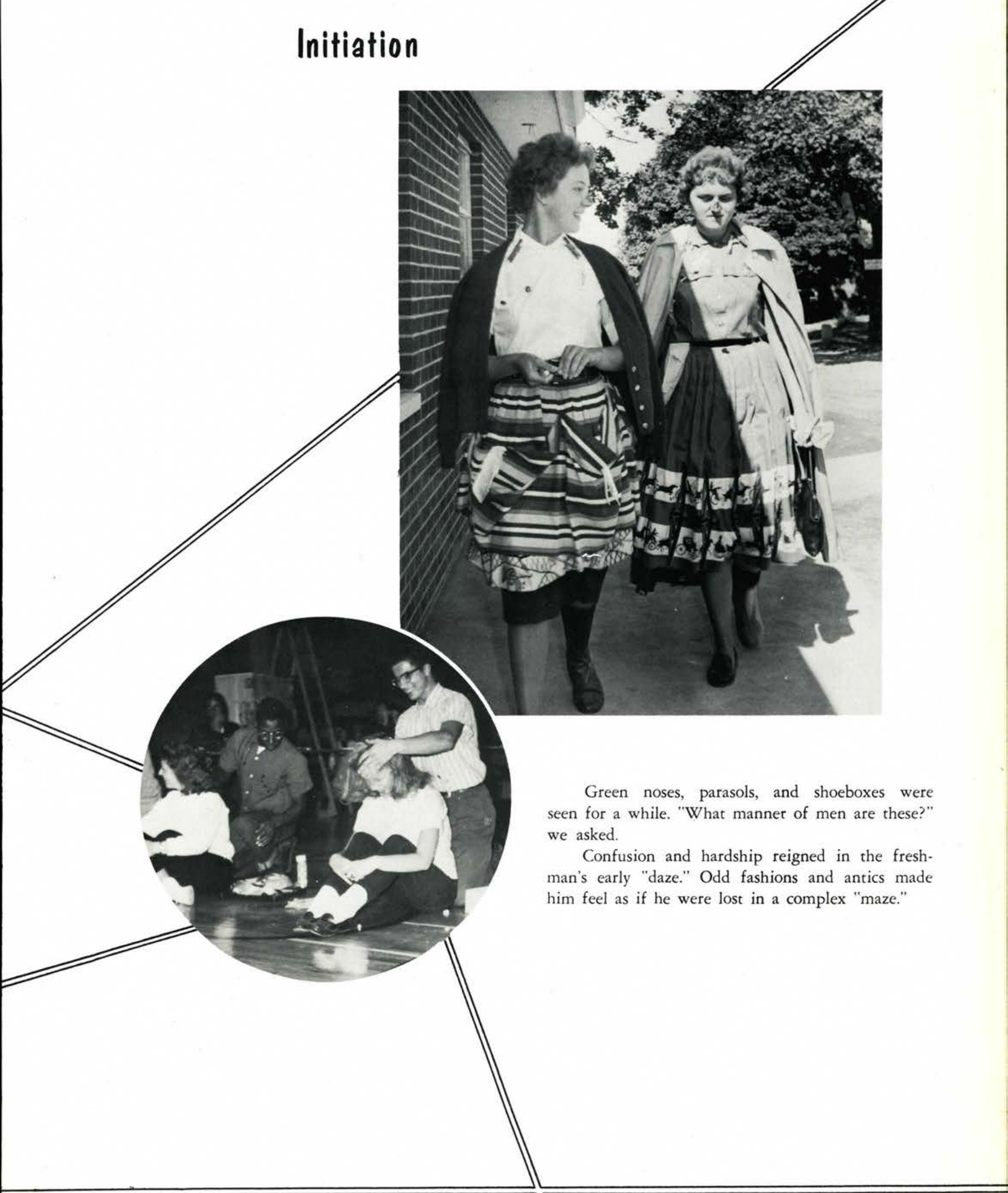




\section{Homecoming Weekend}

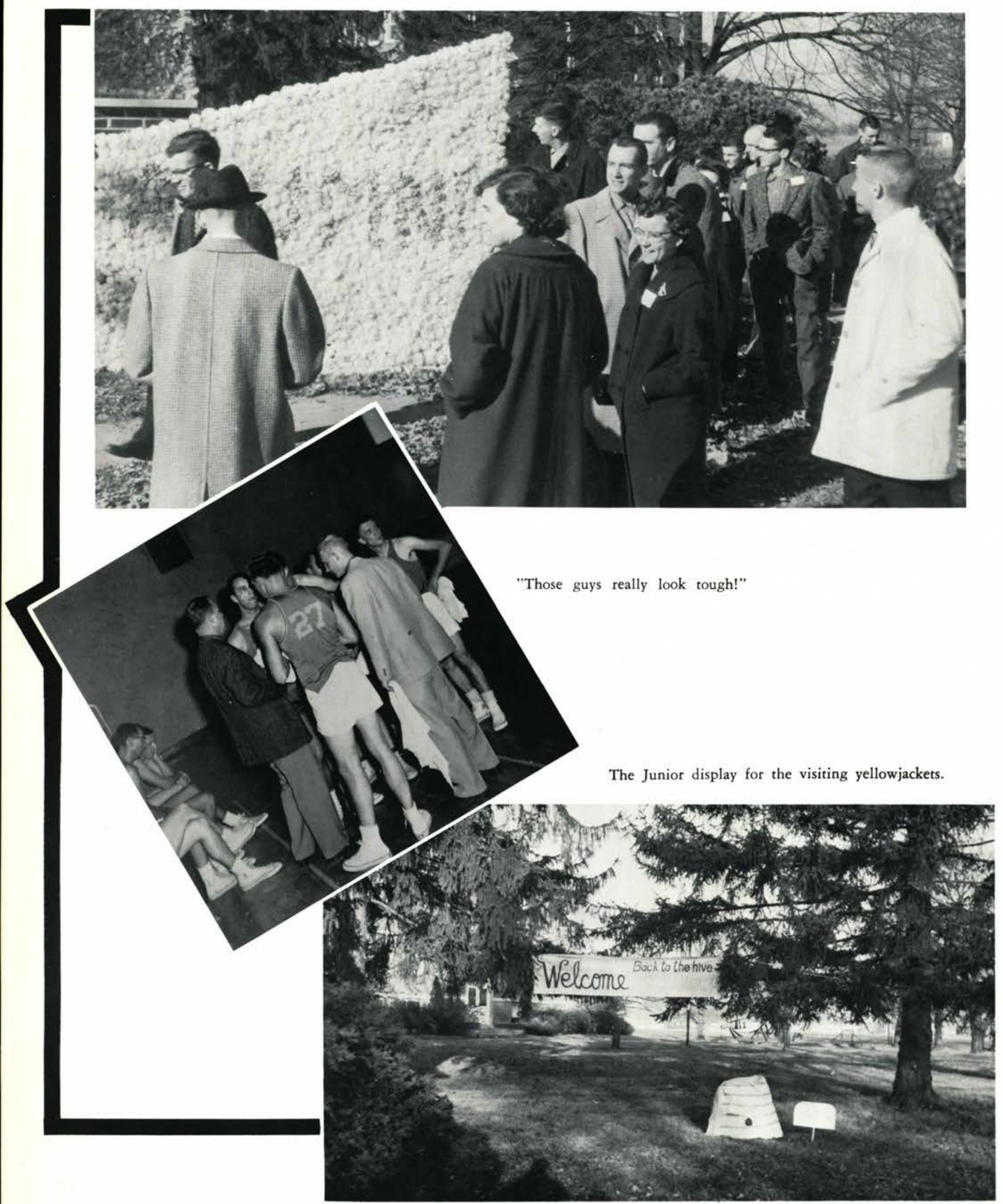




\section{Homecoming Play}

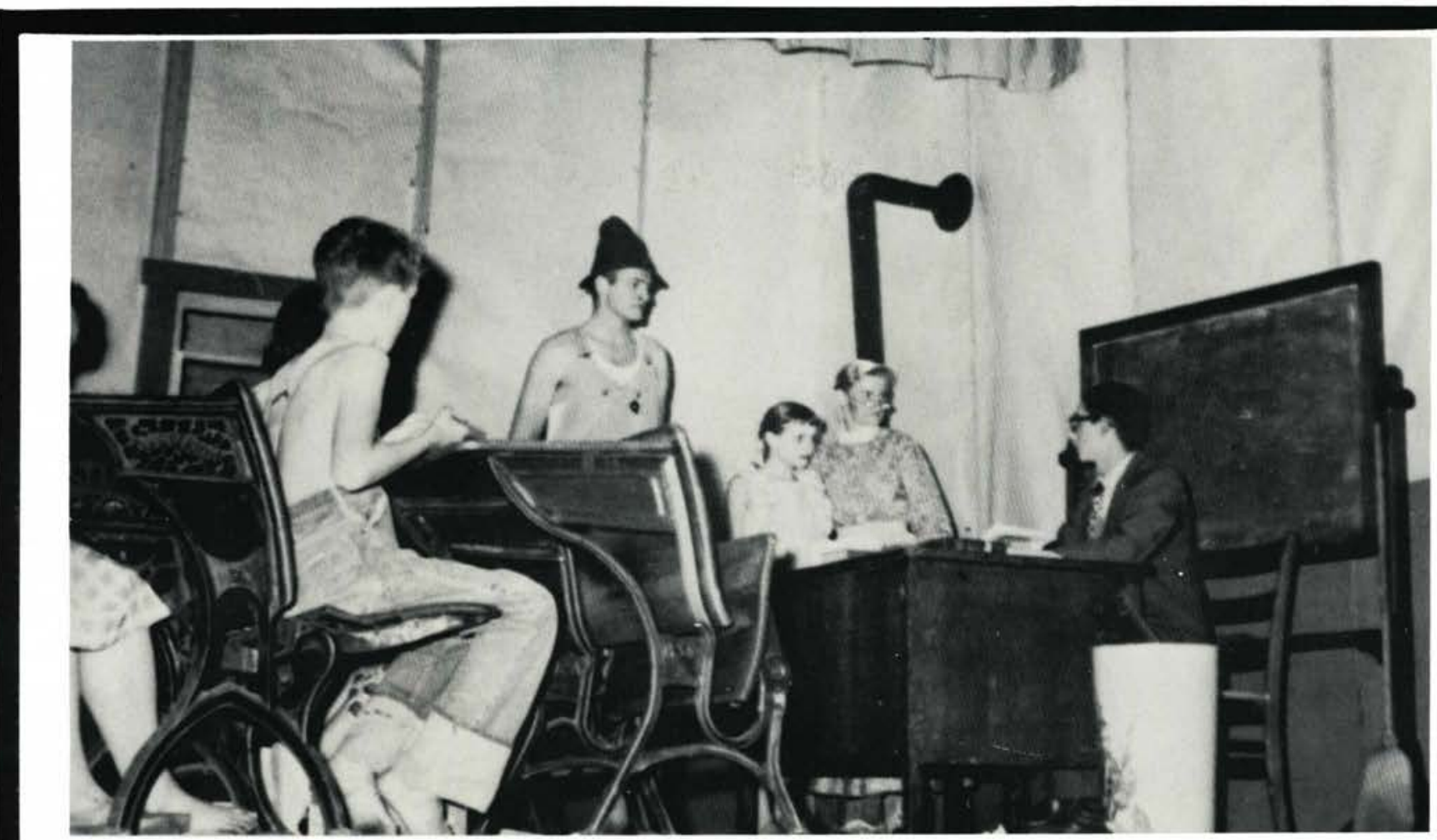

The Thread That Runs So True

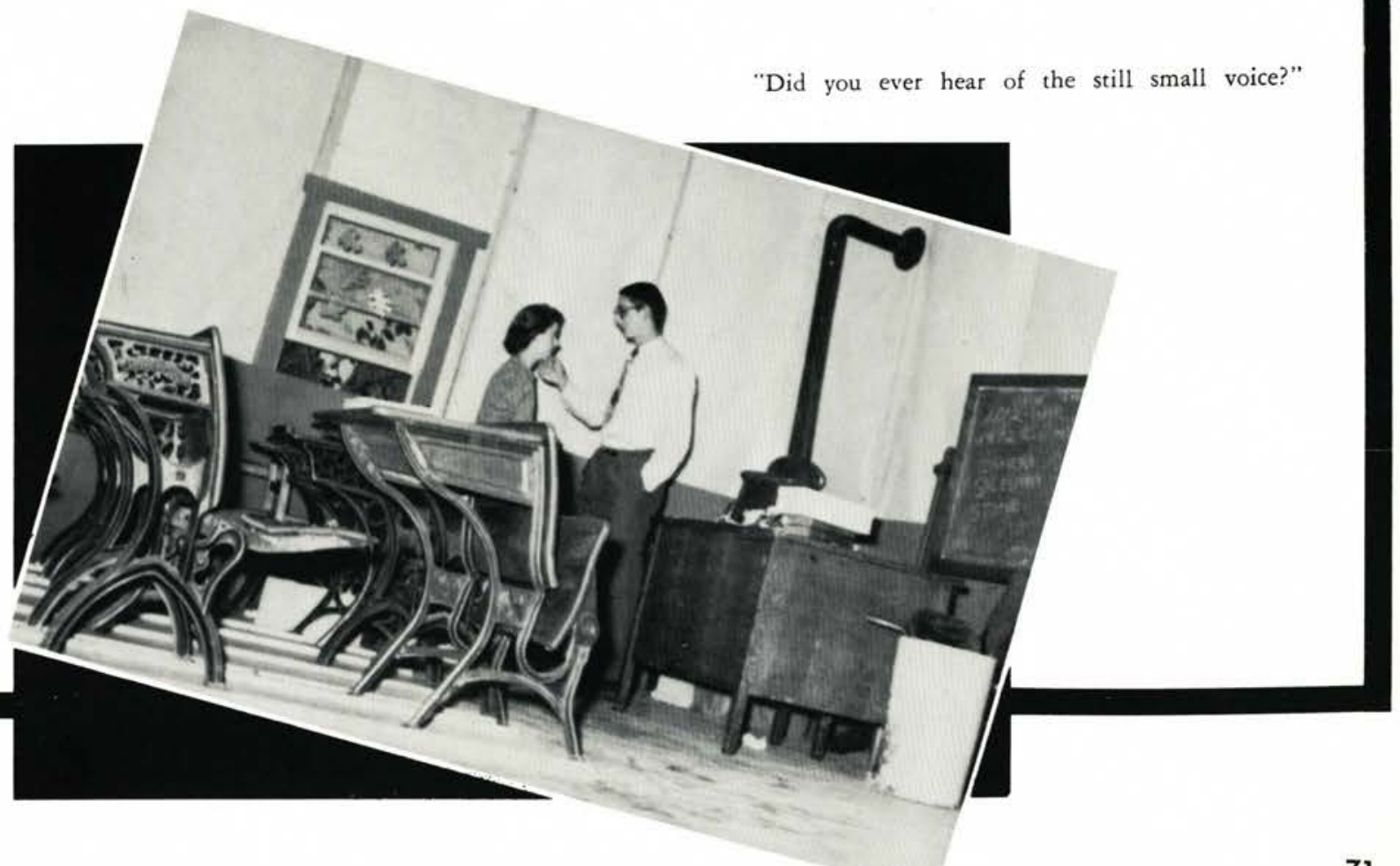




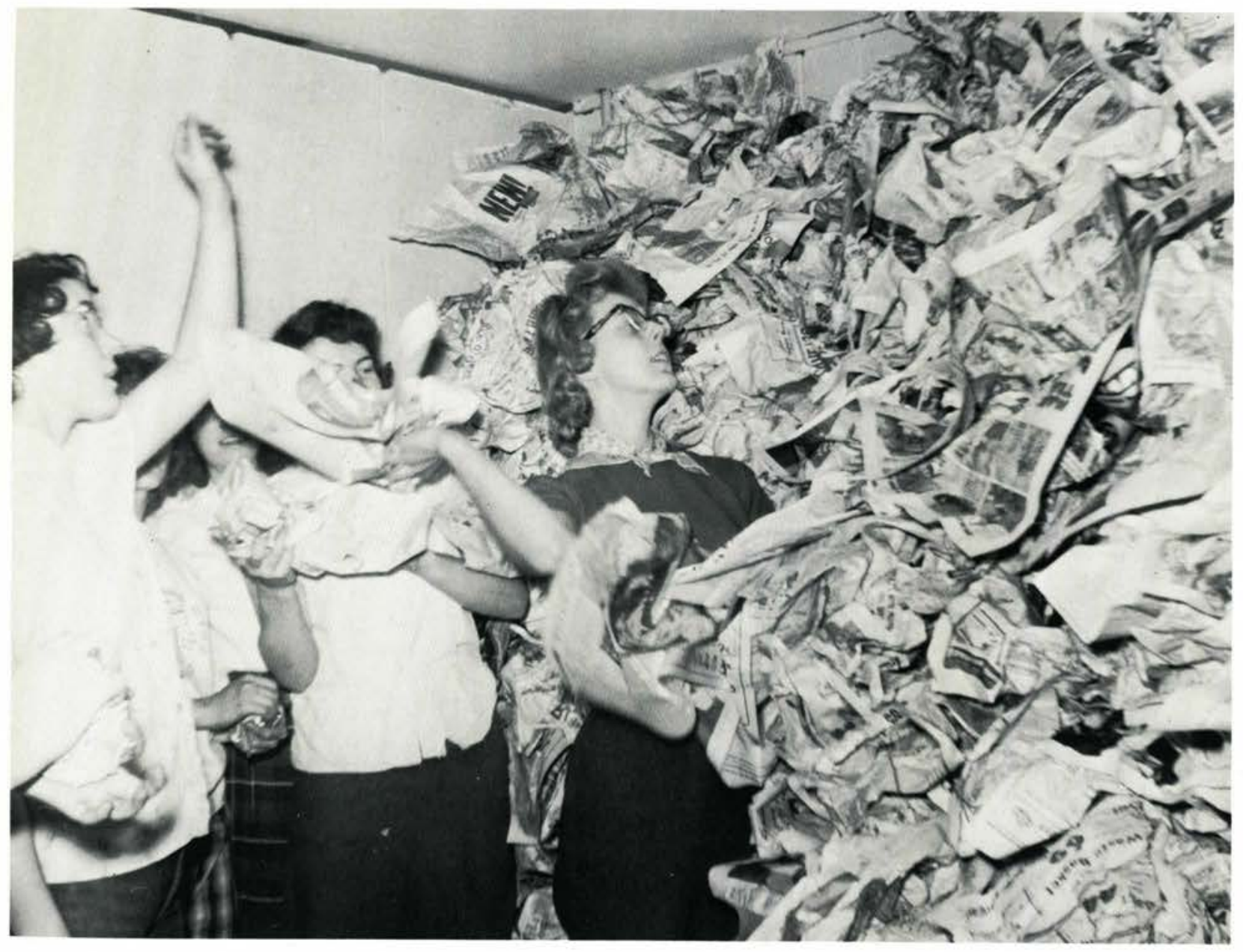

Whee! What fun! Donis, Nancy, and Carol join together for a paper-throwing contest . . or are they preparing for the seniors' return.

\section{Senior Sneak}

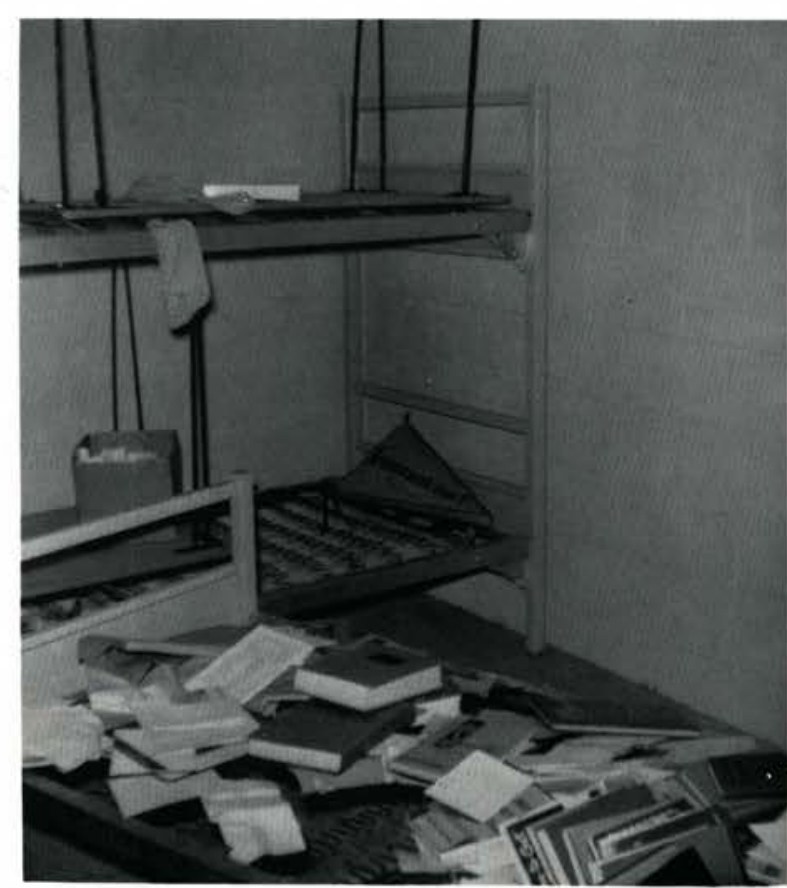

Oh, oh. Juniors at work. No Trespassing!

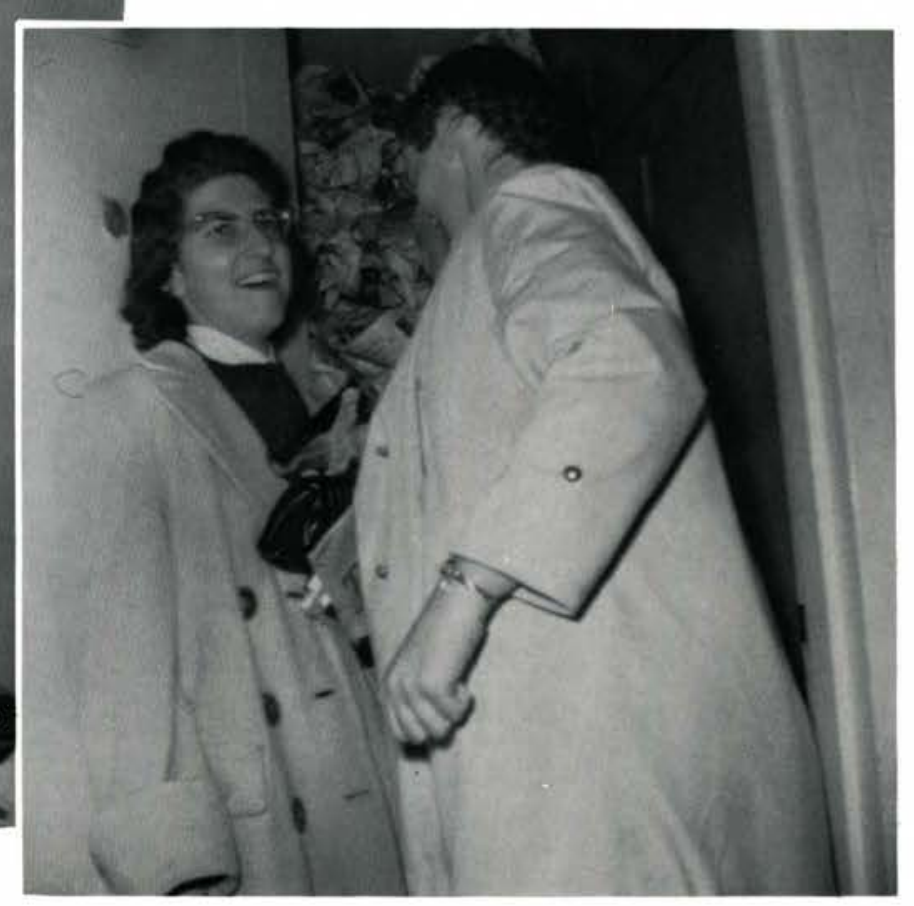

No lights, but we sure have lots of paper. Sharon and Barb seem to be having difficulties. 


\section{Christmas Party}

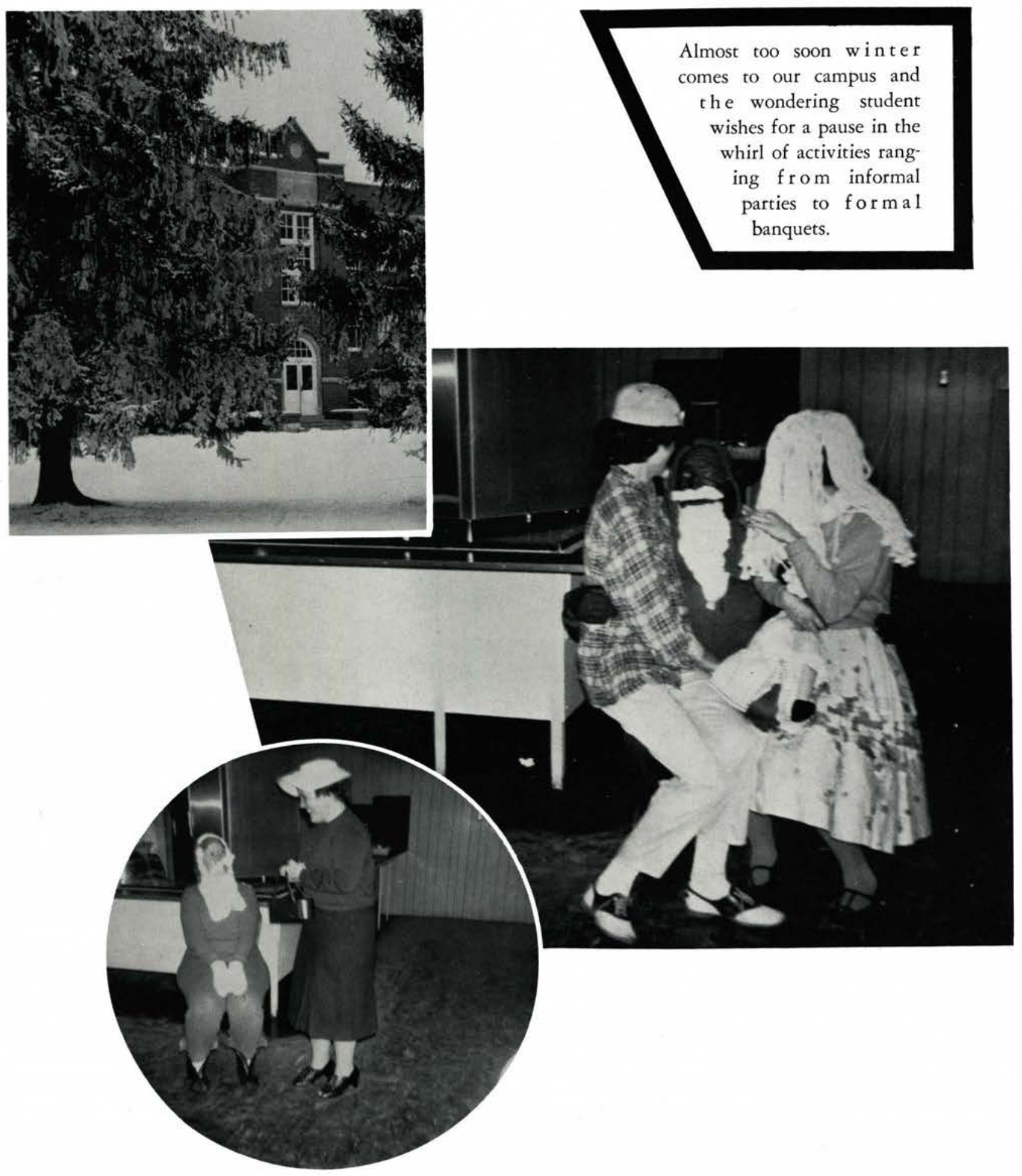




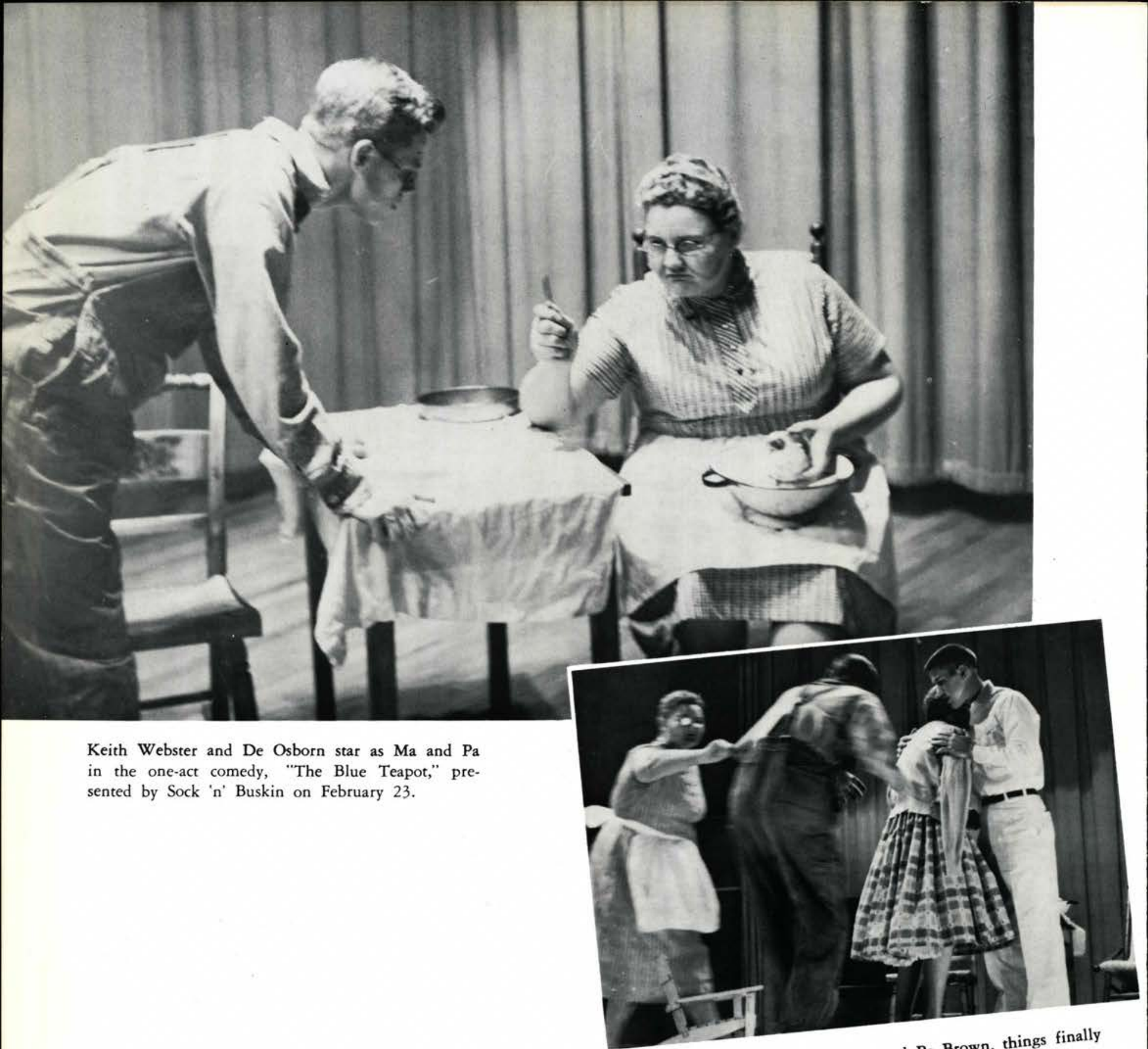

With the help of $\mathrm{Ma}$ and $\mathrm{Pa}$ Brown, thing and Jimmy look better to
(Don Adams).

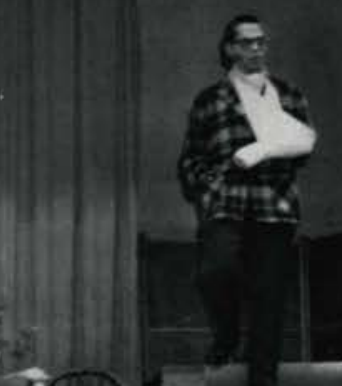

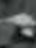

$-\mathbf{T} \mathbf{y}^{2}$

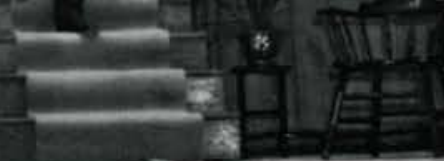

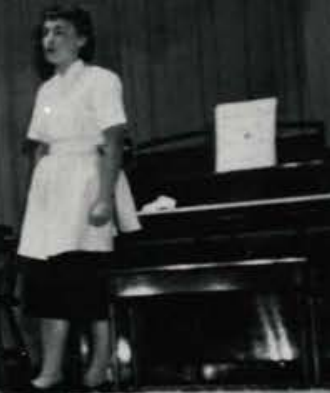

Dave Matson as David Lawrence, the great violinist, and Esther Weiss, the maid, open the curtain to "Andante." 

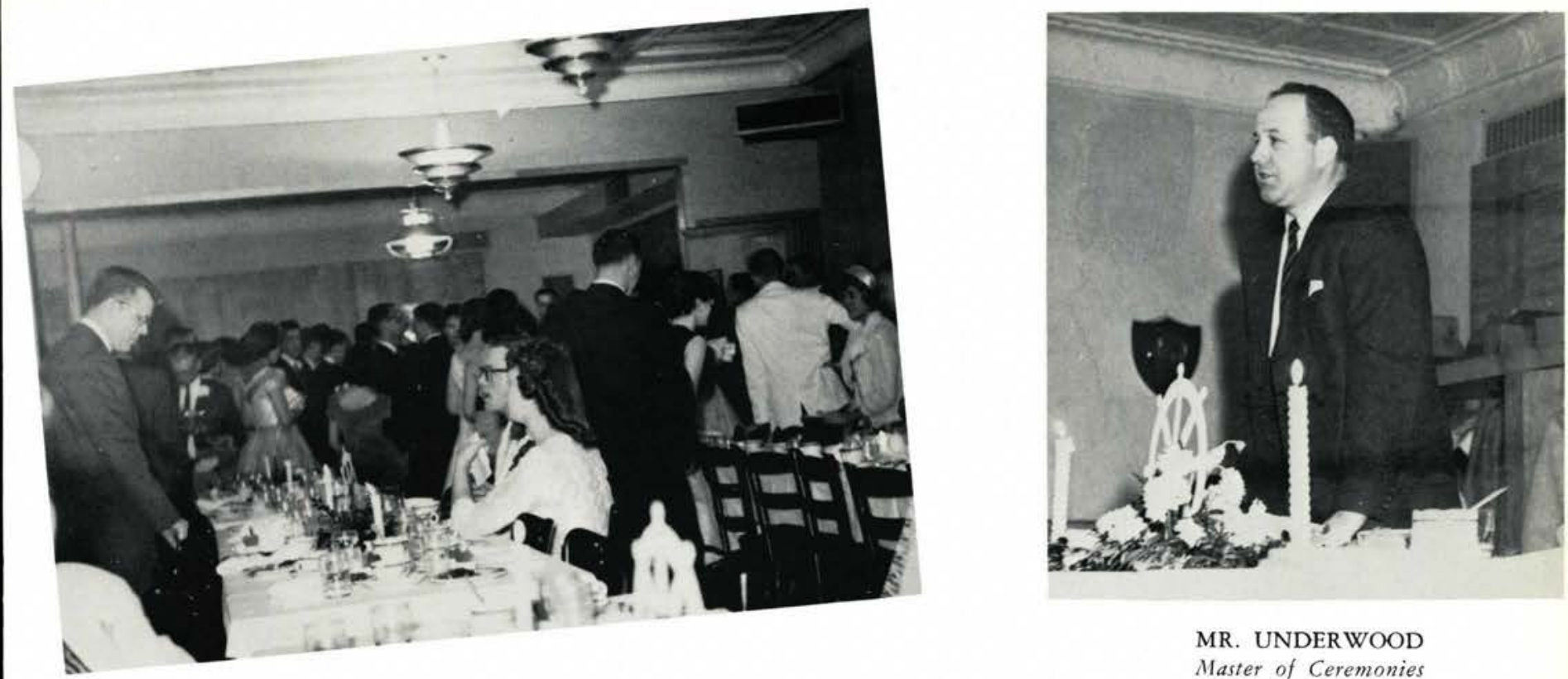

MR. UNDERWOOD

Master of Ceremonies

"Ports of Love" was the theme of the program for the Valentine Banquet this year, which was again sponsored by Gamma Chi. A trip of romance was taken to many "far away places" but ended happily in those "old familiar places."

\section{Valentine Banquet}

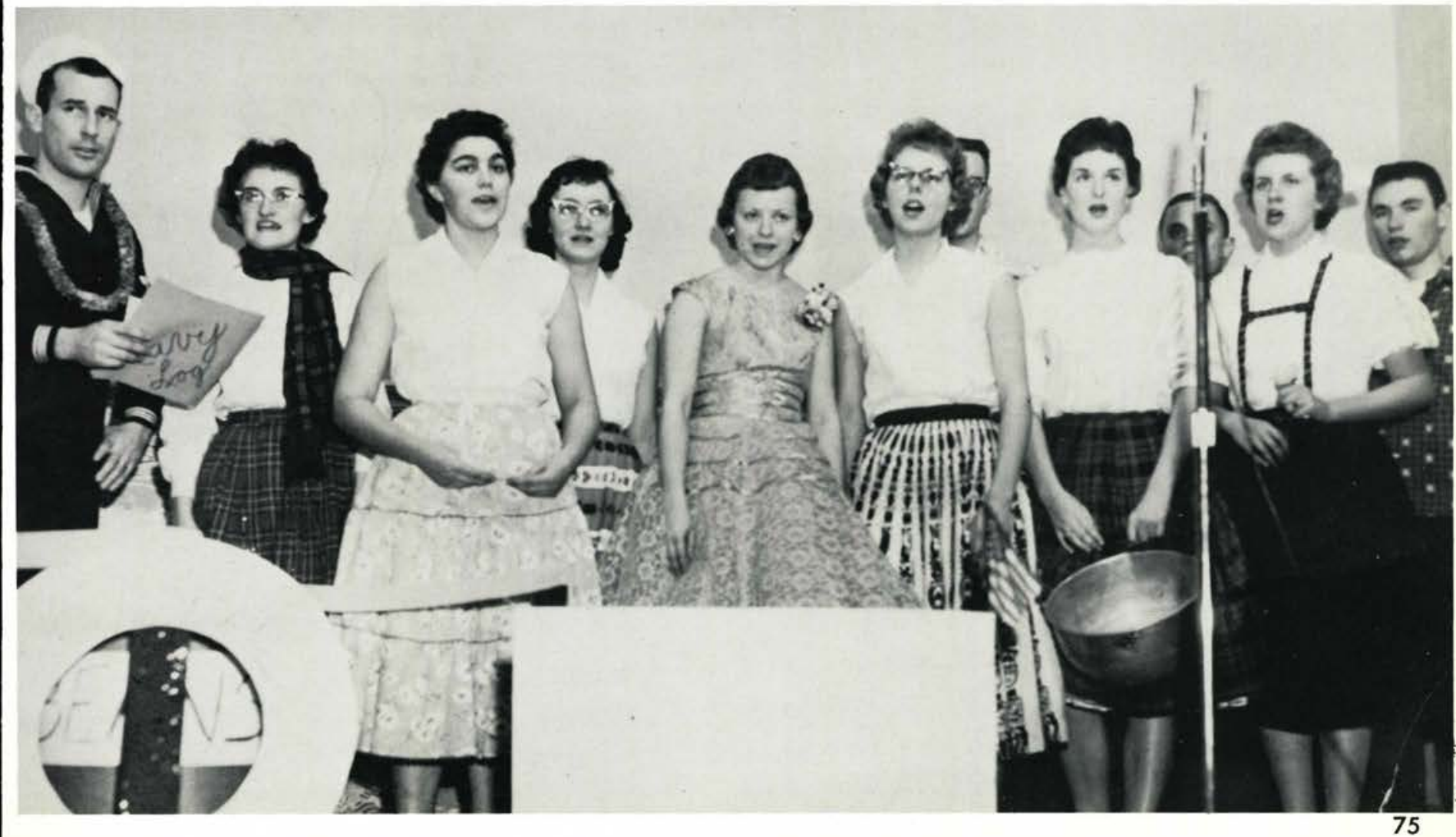




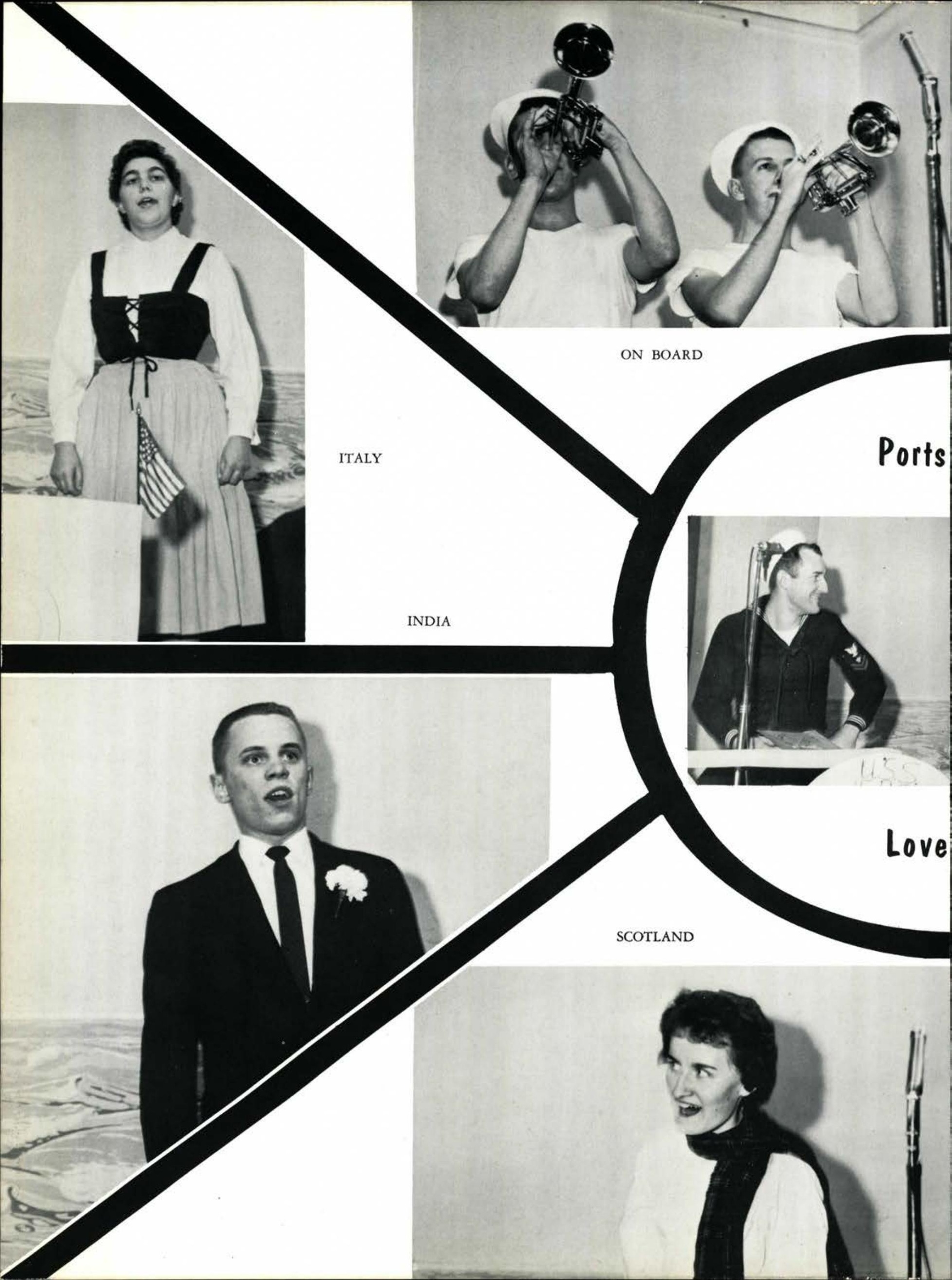




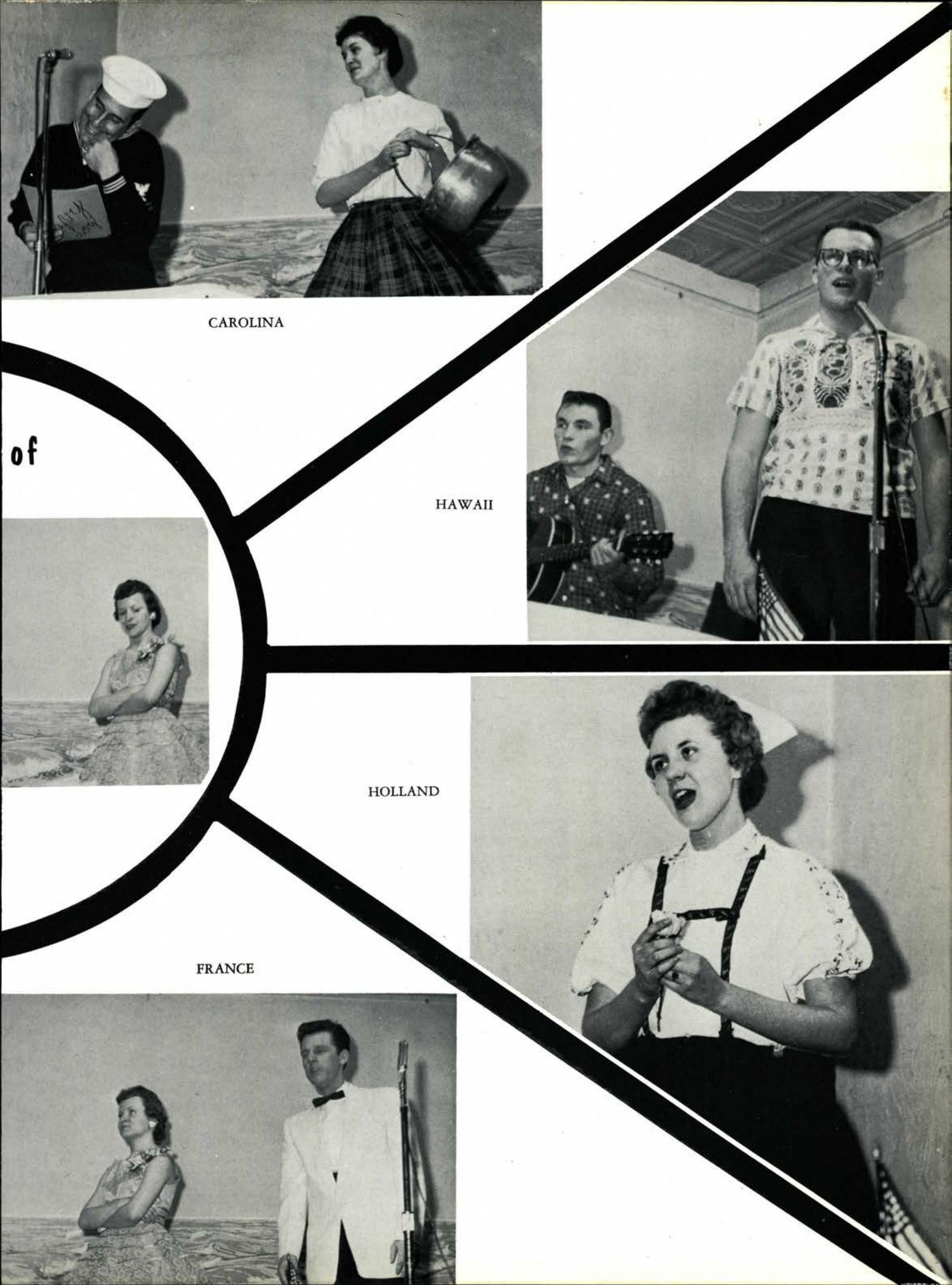




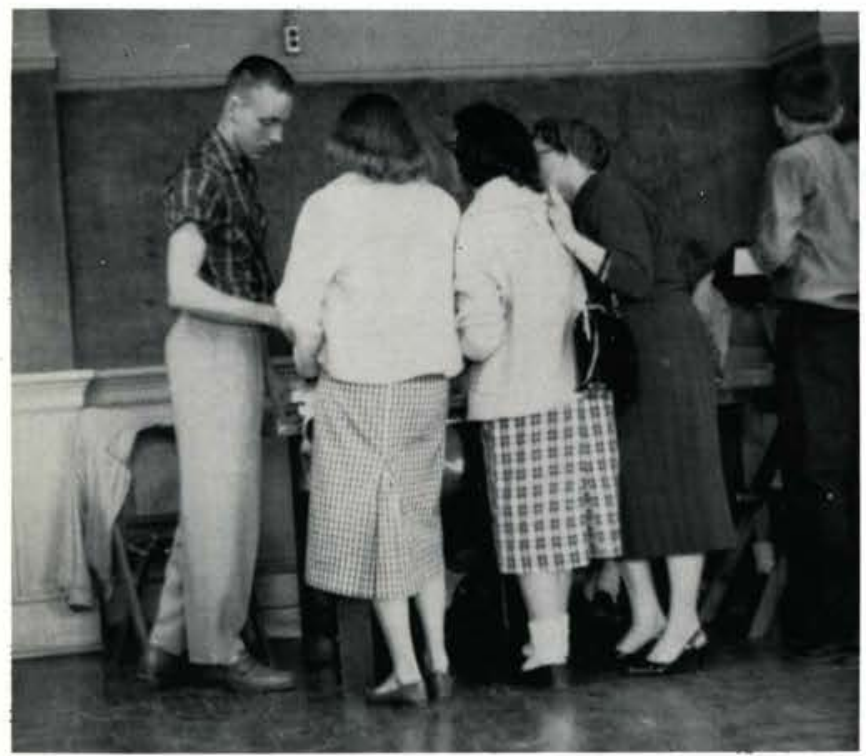

Students register for a place to stay.

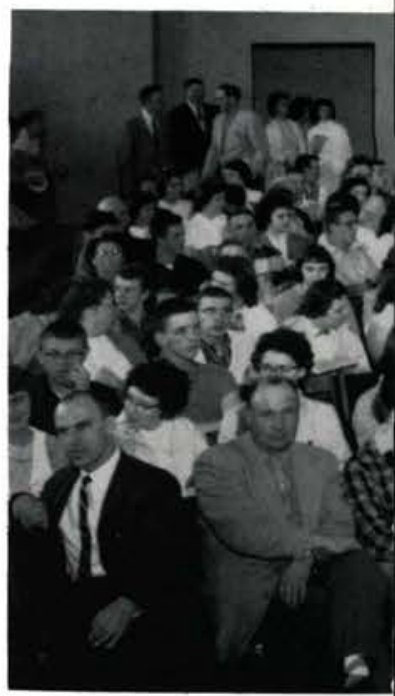

\section{PROSPECTIVE CONFE}

Ruth Himsel gives one of the many guided tours.

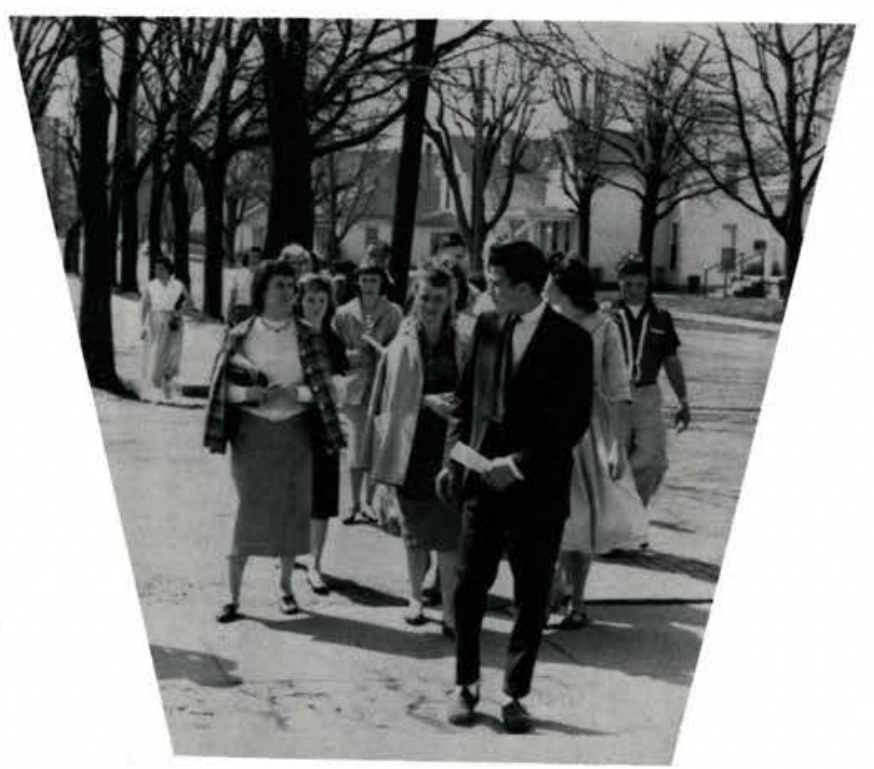




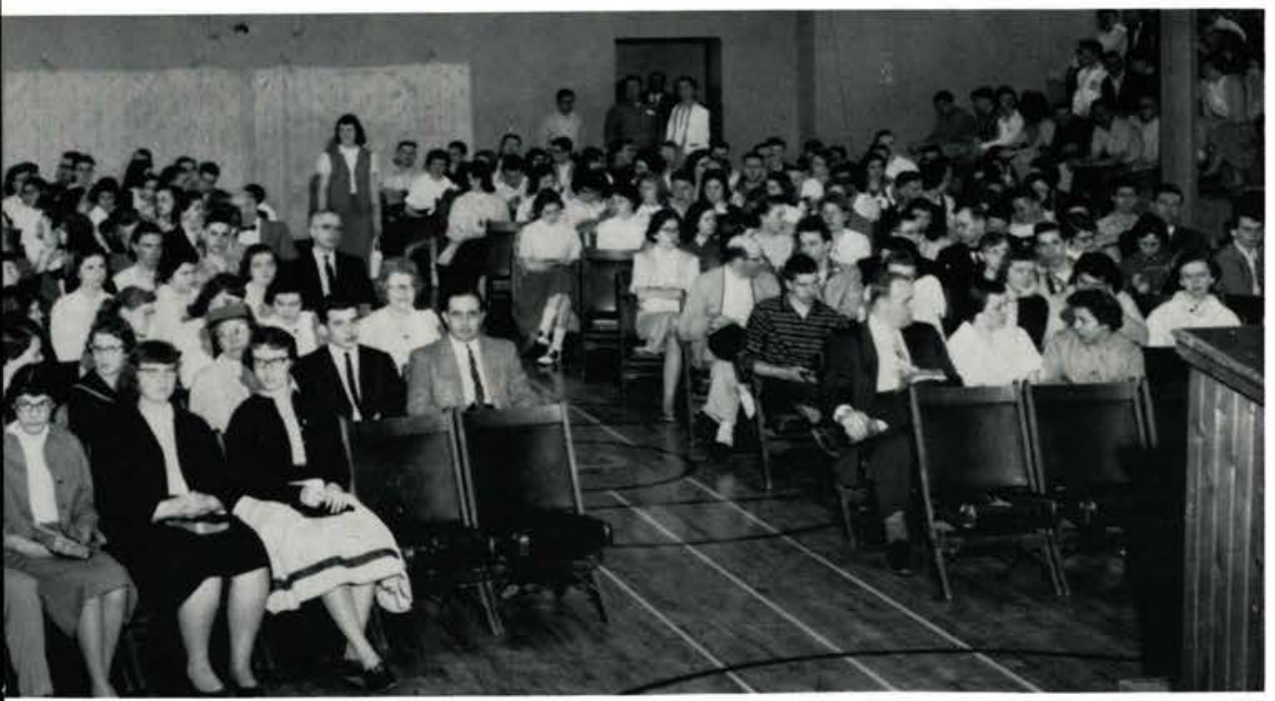

Everyone gathers in the gym for fun and fellowship.

\section{STUDENTS}

RENCE

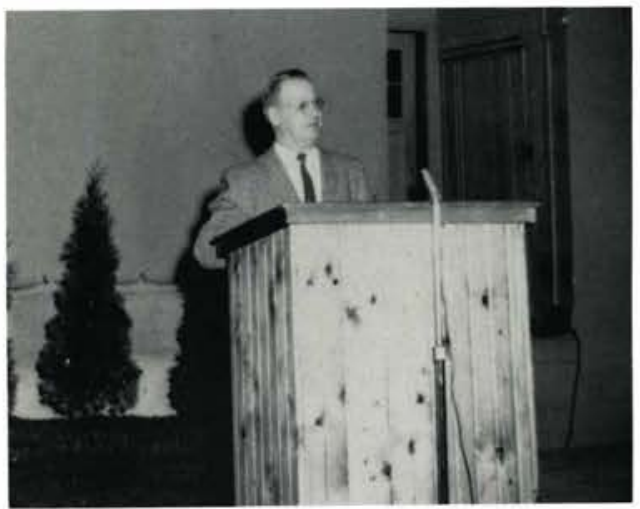

Dr. Dunham bringing one of the Spring Bible Lectures.

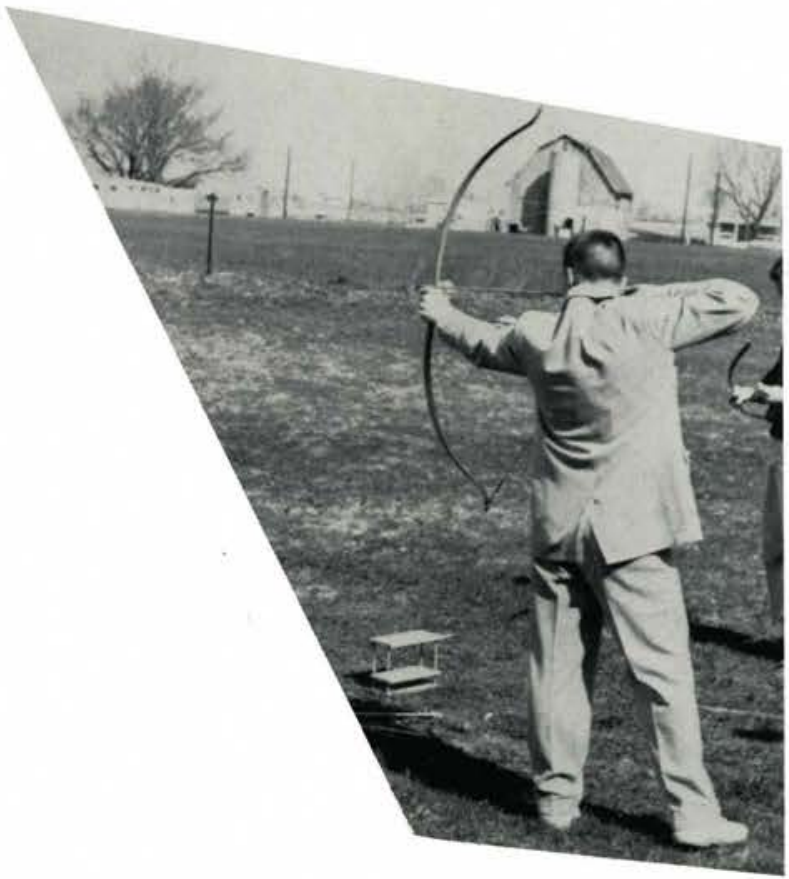

"Just like Robinhood." 


\section{CHOIR TOUR}

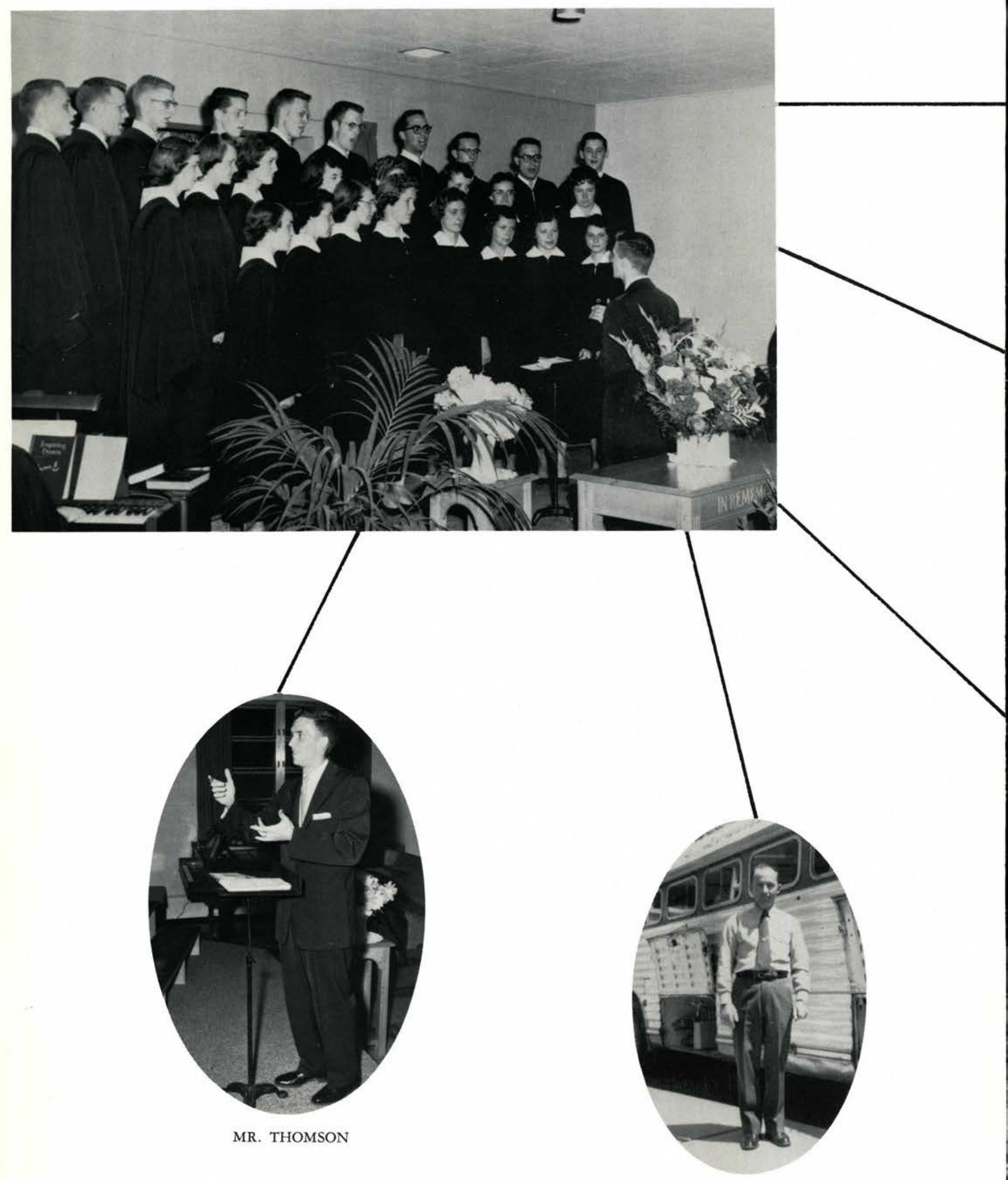

"BROWNIE" 
Excitement, places of interest, and memorable experiences characterized the 1959 tour of the Chapel Choir through Ohio and Michigan. The most wonderful and lasting part of all was the blessing received as a result of the working of the Lord in the lives of both the choir members and the audiences as the gospel message, was given in song.

The last suitcase is in and...

"We're off."

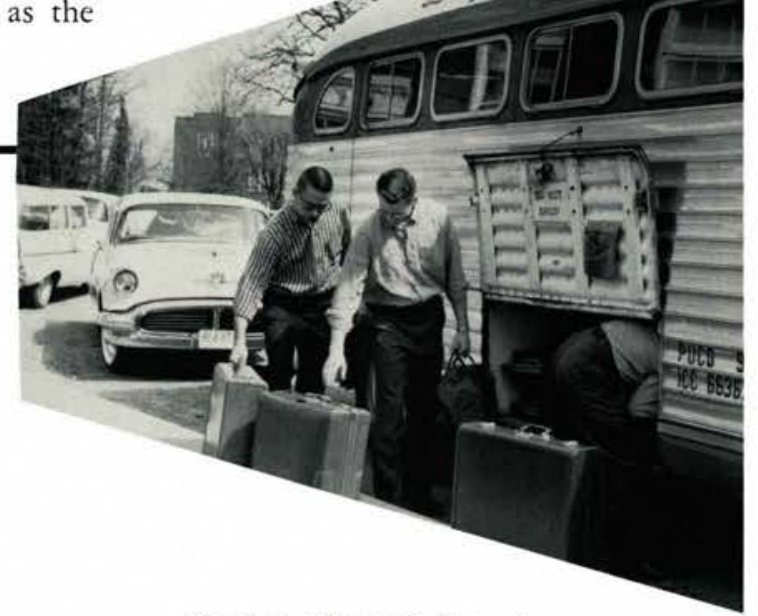

\section{"We're off."}

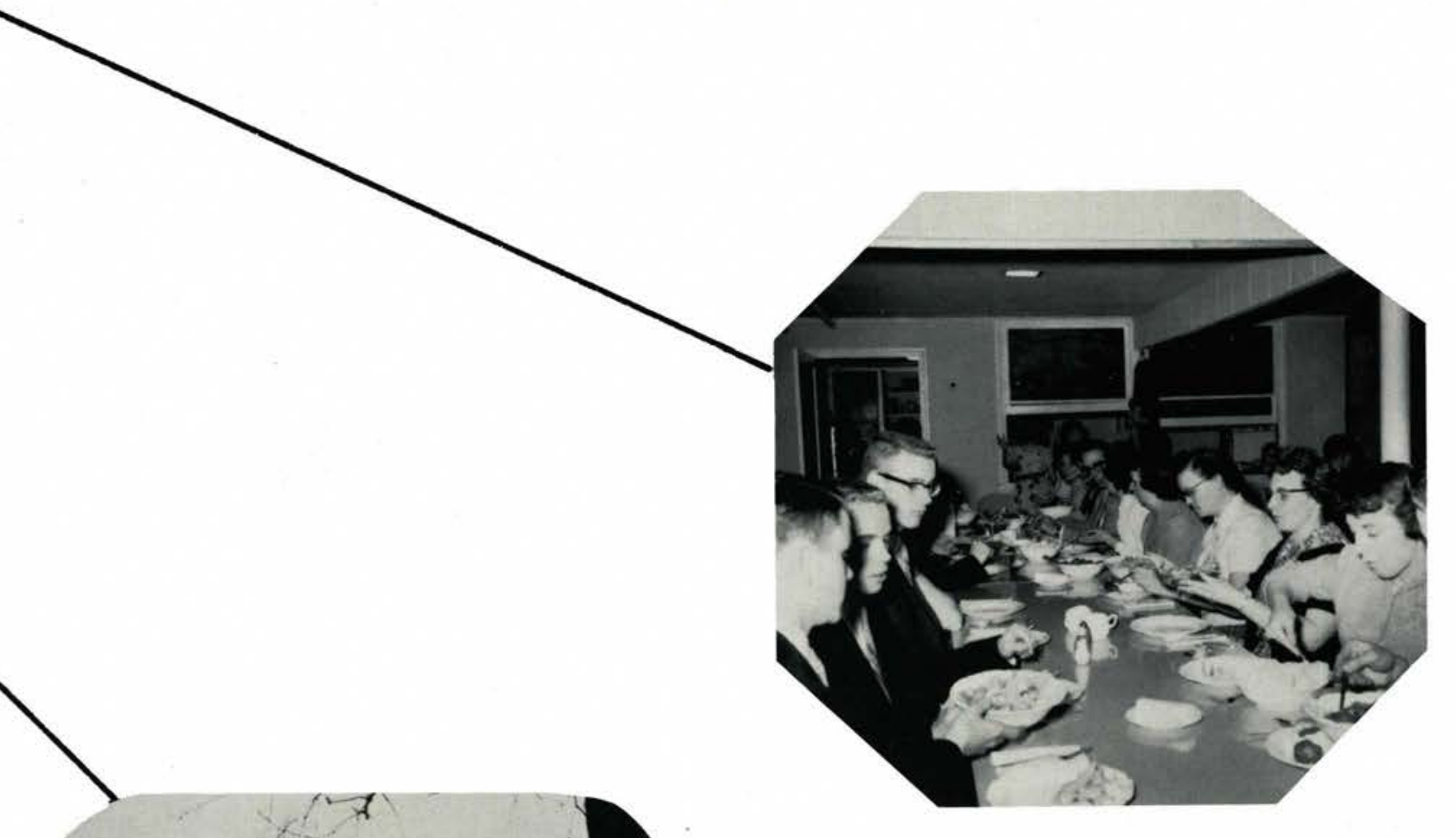

Mmm ... What a feast!

Come on! Let's play ball! 


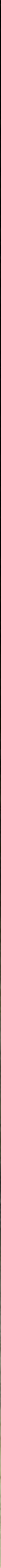




\section{GRADUATION}
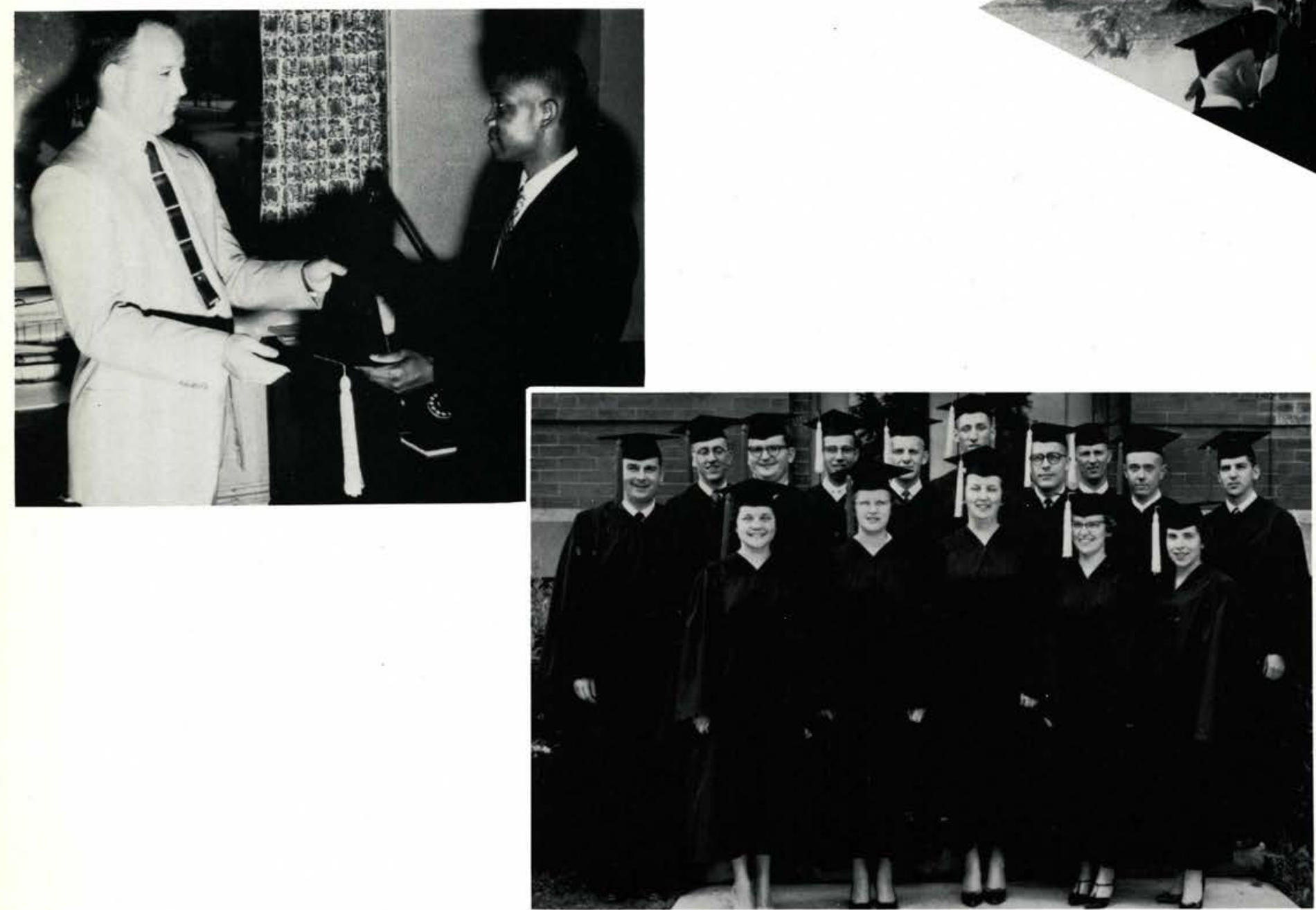

Class of '59

Graduation Speaker

DR. JOHN MURRAY

Ringwood, New Jersey

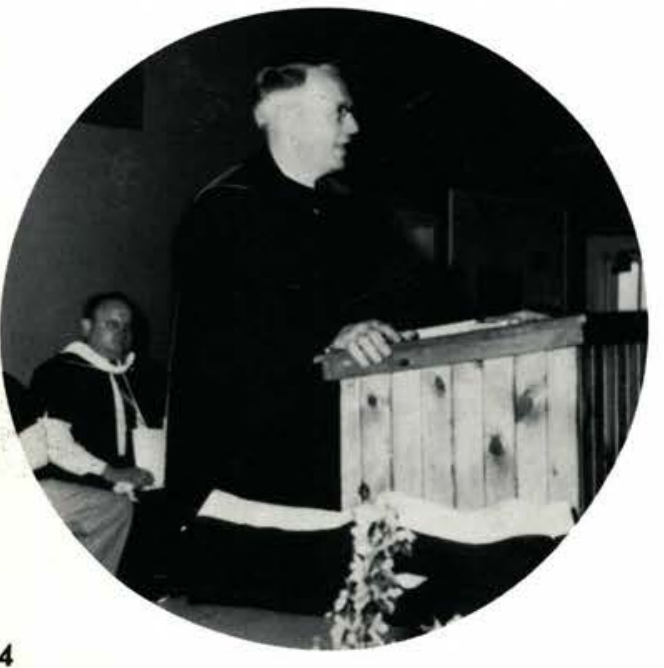




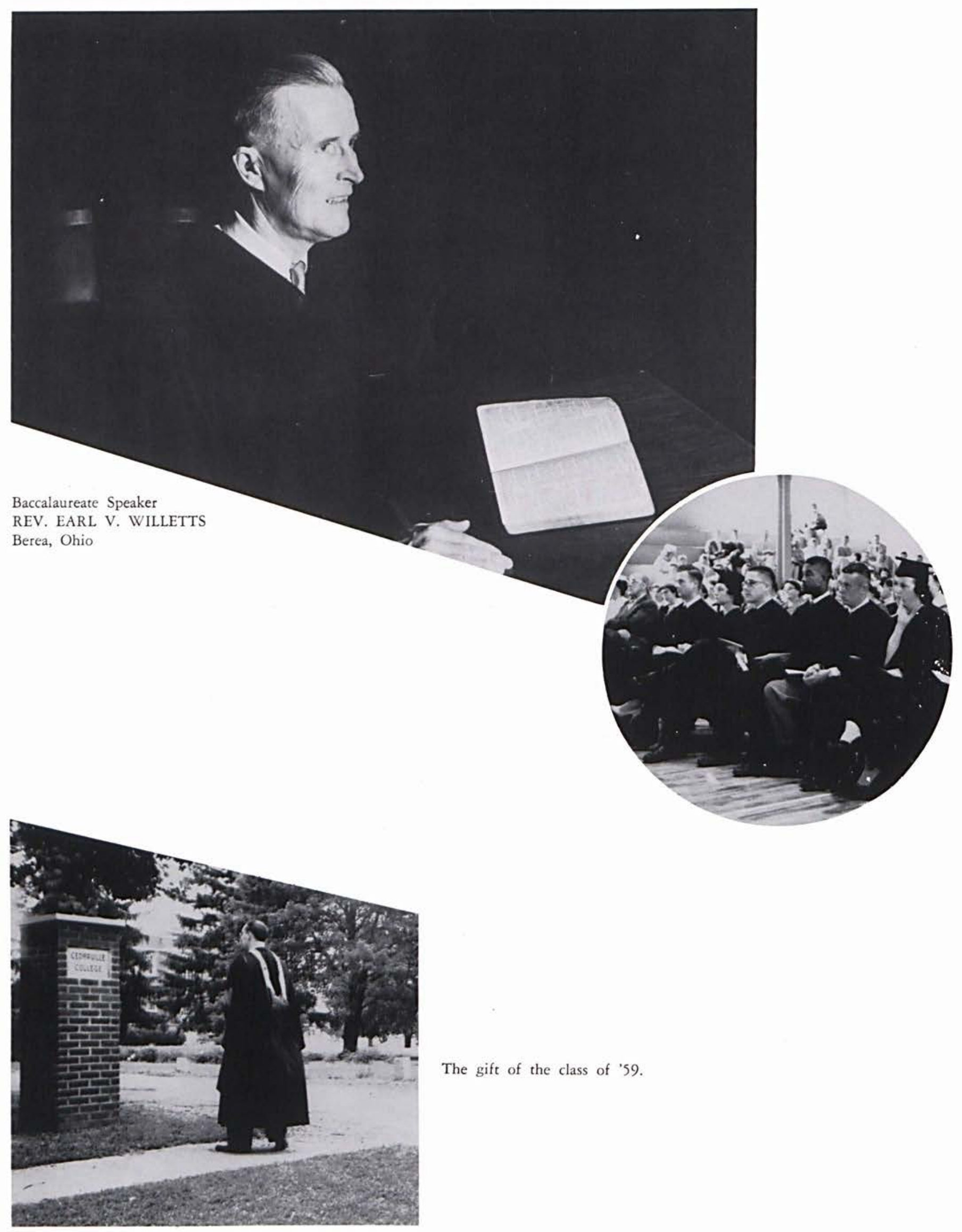


$A^{*}+2+4 \pi$

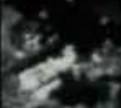

y

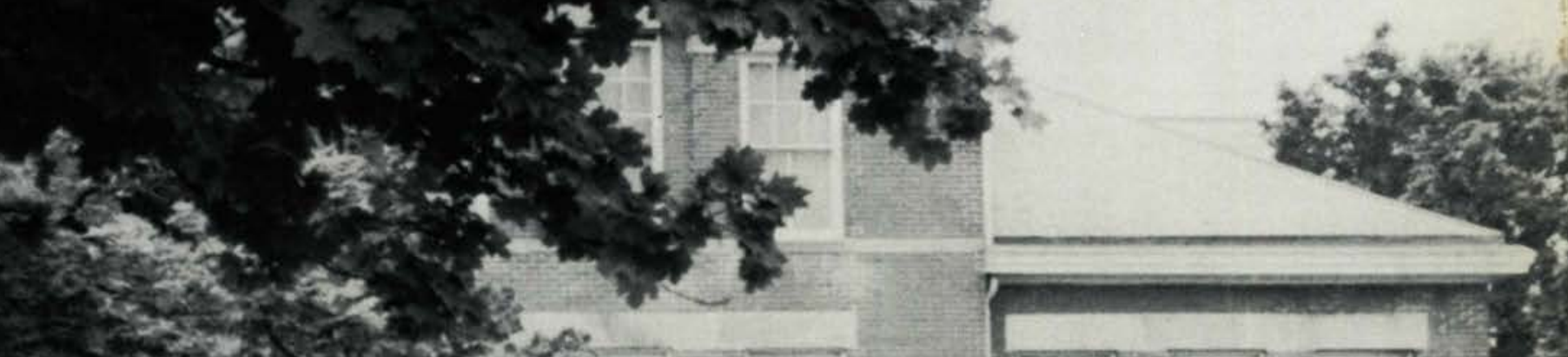

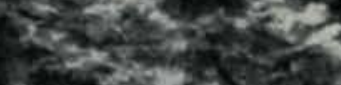

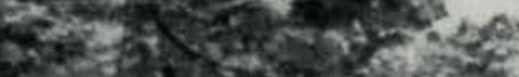

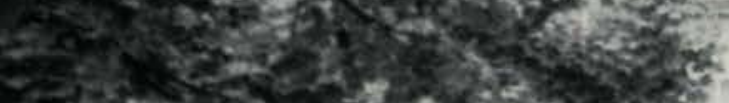

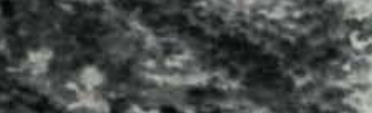

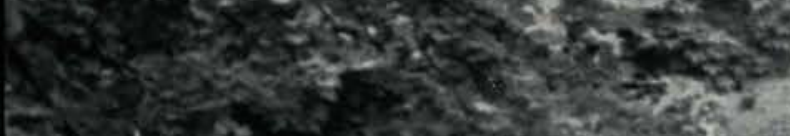

E.t. 3 . of
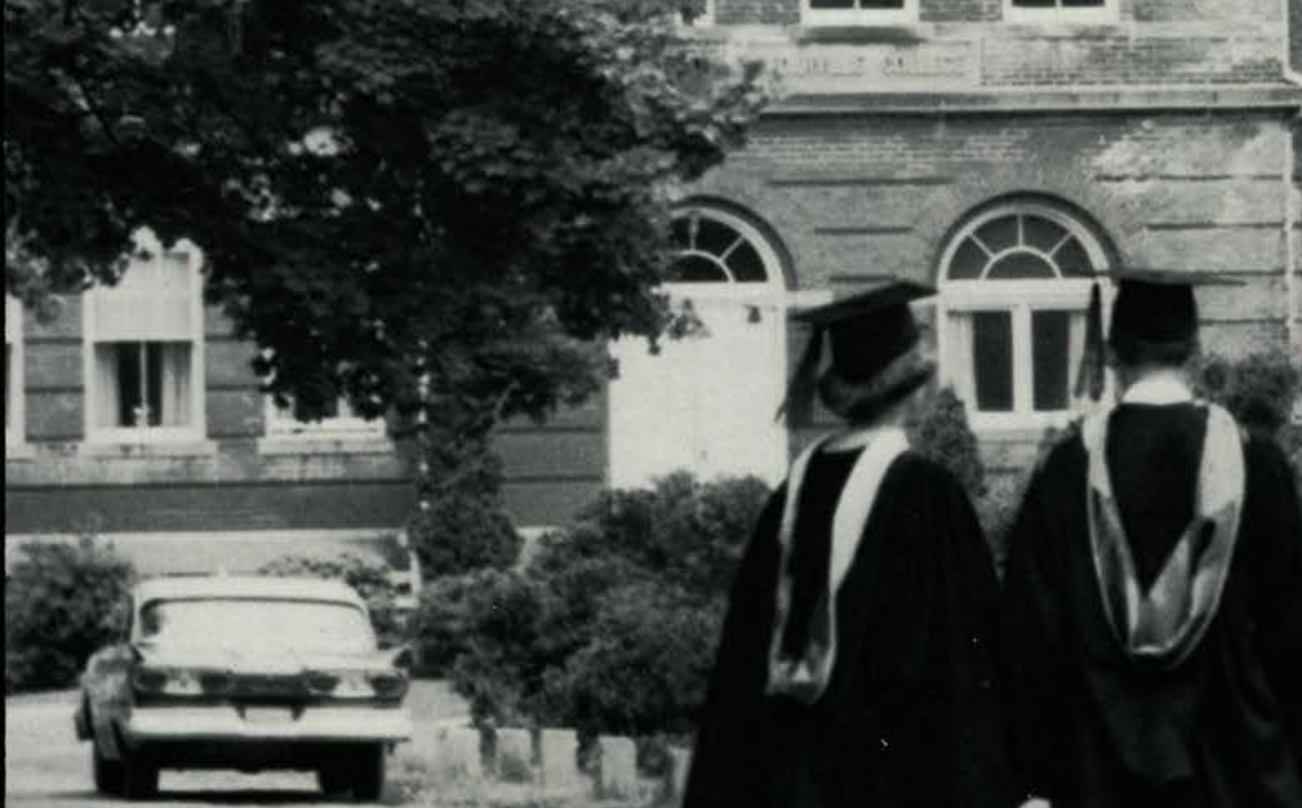

$\cos 20$

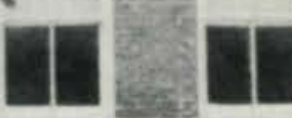

onts
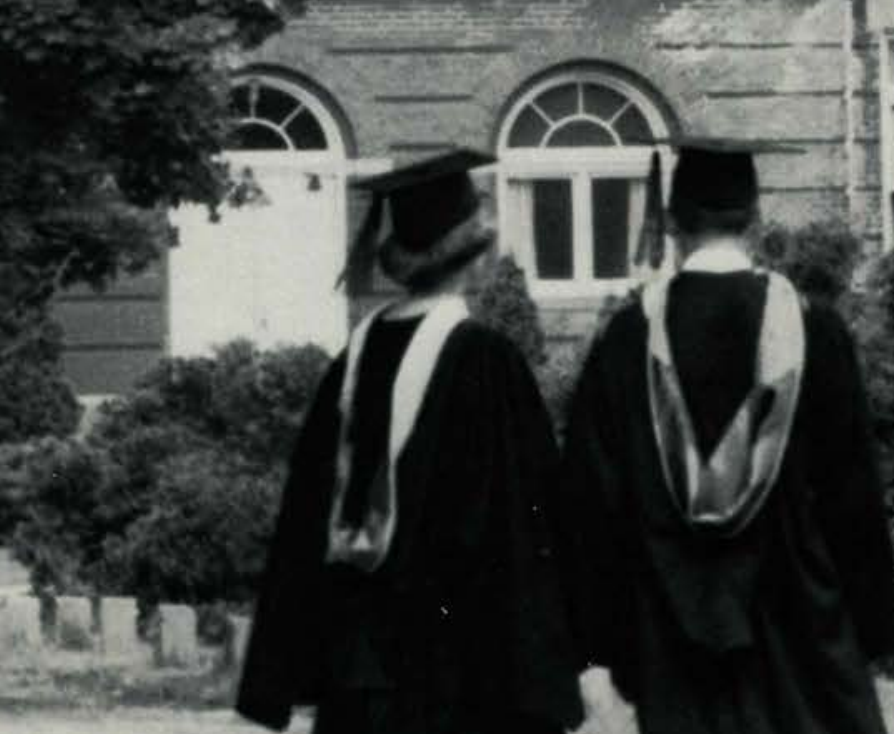

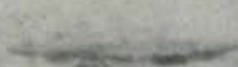
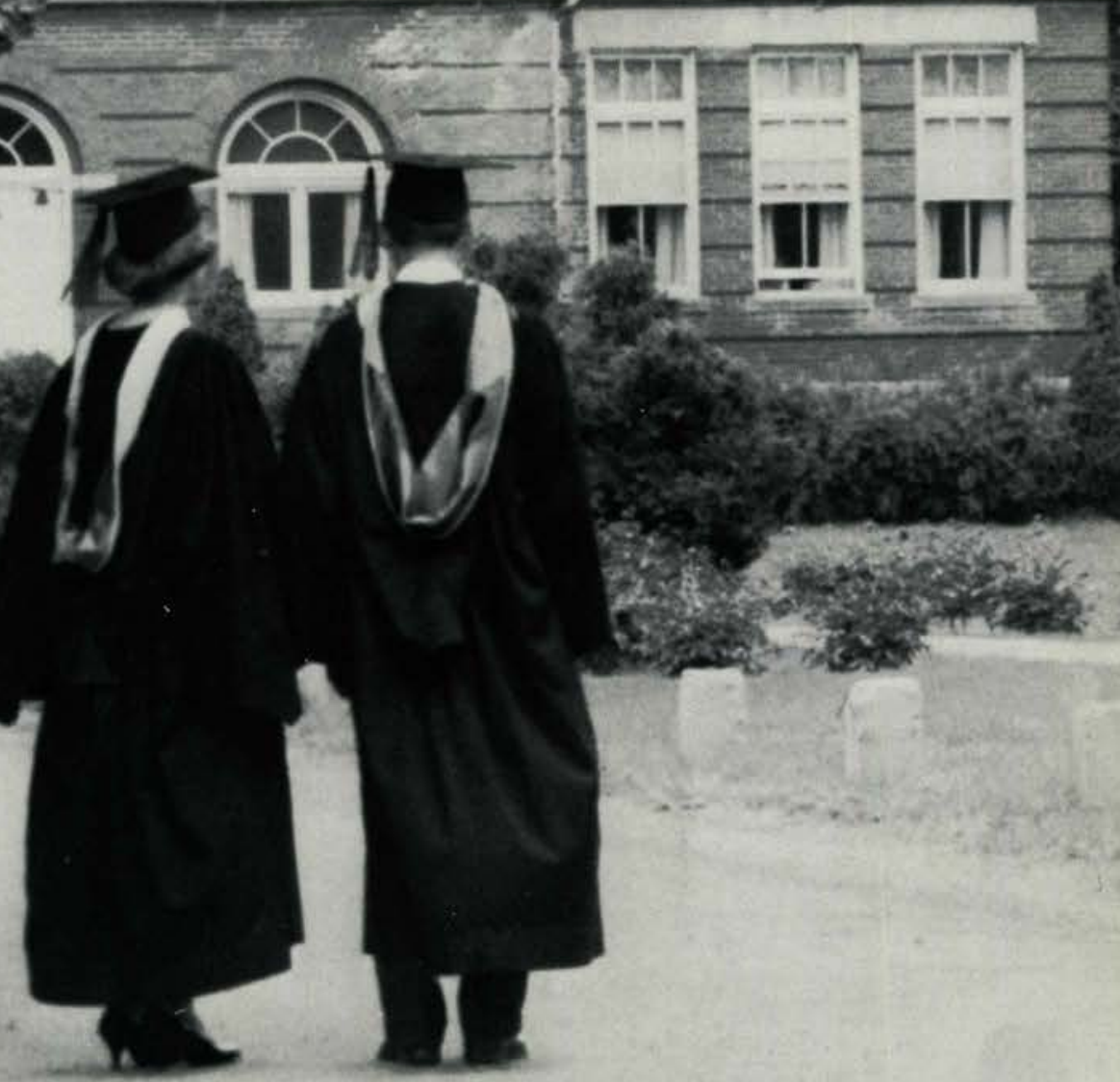

setes?

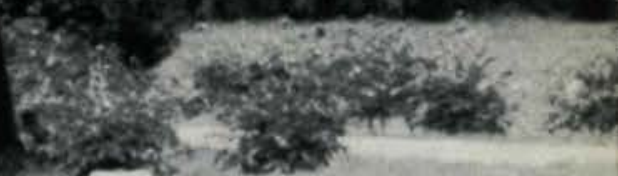

There are the remembrances of good times throughout the year, but when the time comes to say goodbye the realization of the great unknown that we are stepping into sobers us. Only because of Christ can we have a determination strong enough to carry on the work that $\mathrm{He}$ has called us into and to step out in complete faith knowing that there will be new friends, new times, and new blessings ahead. 



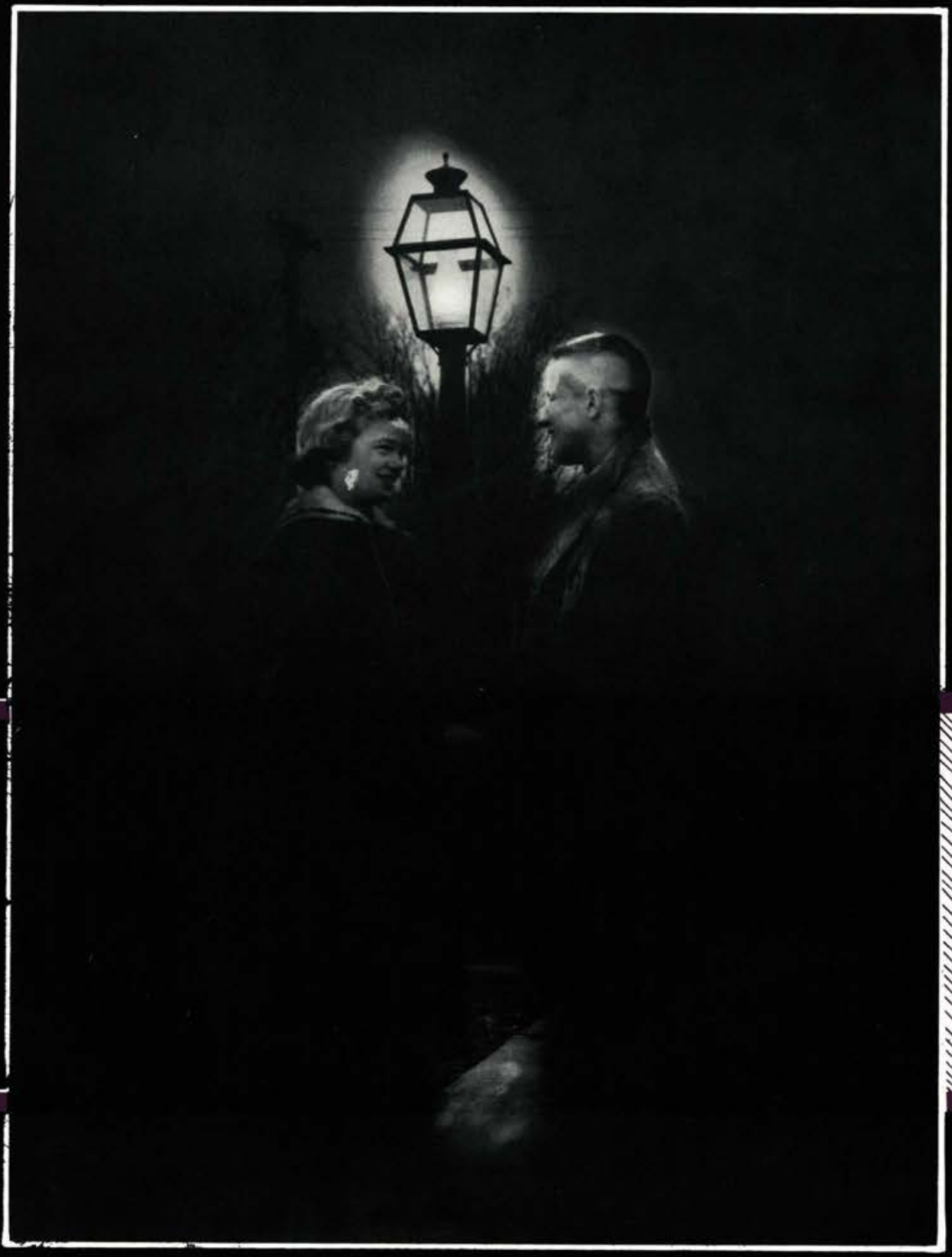



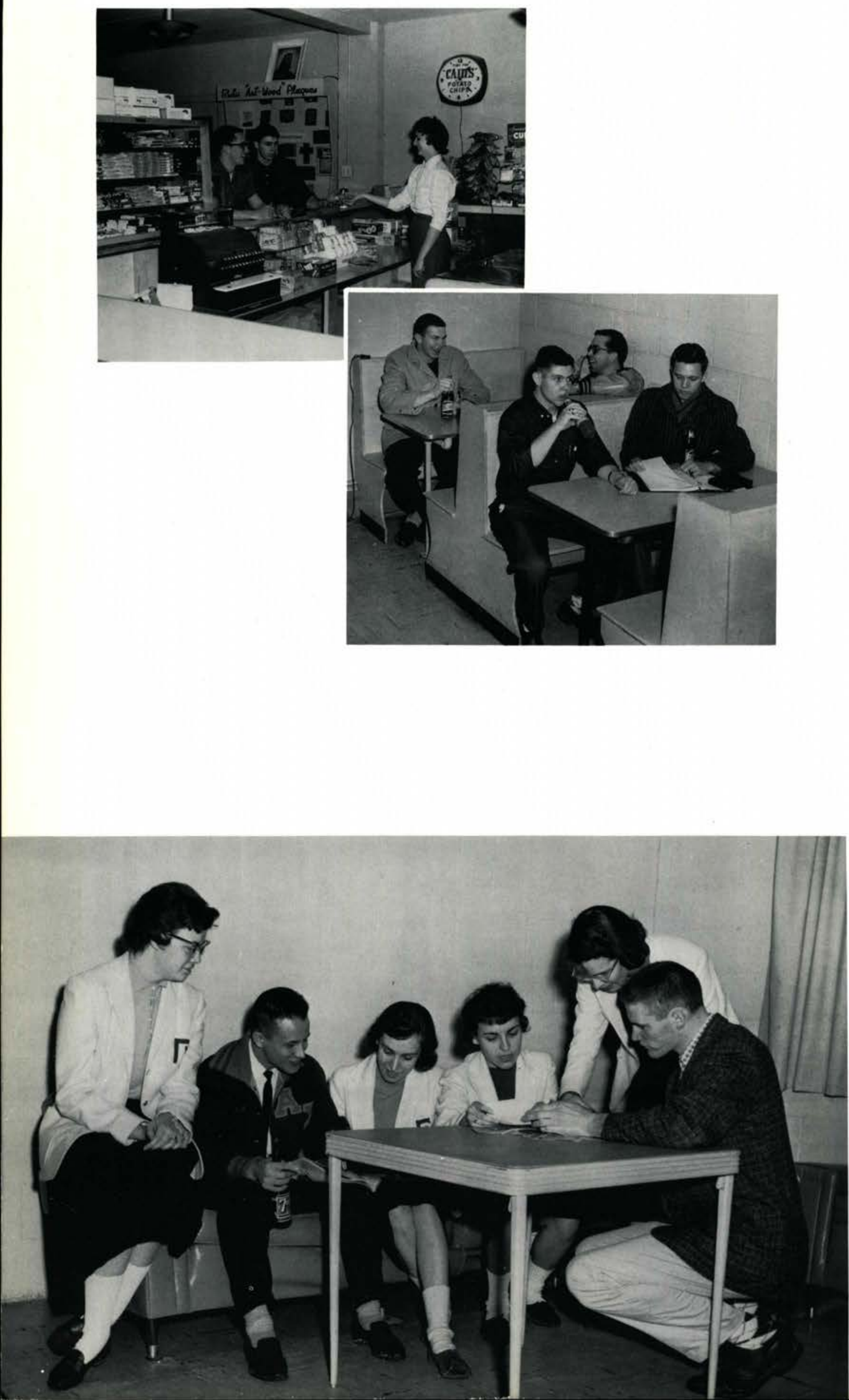

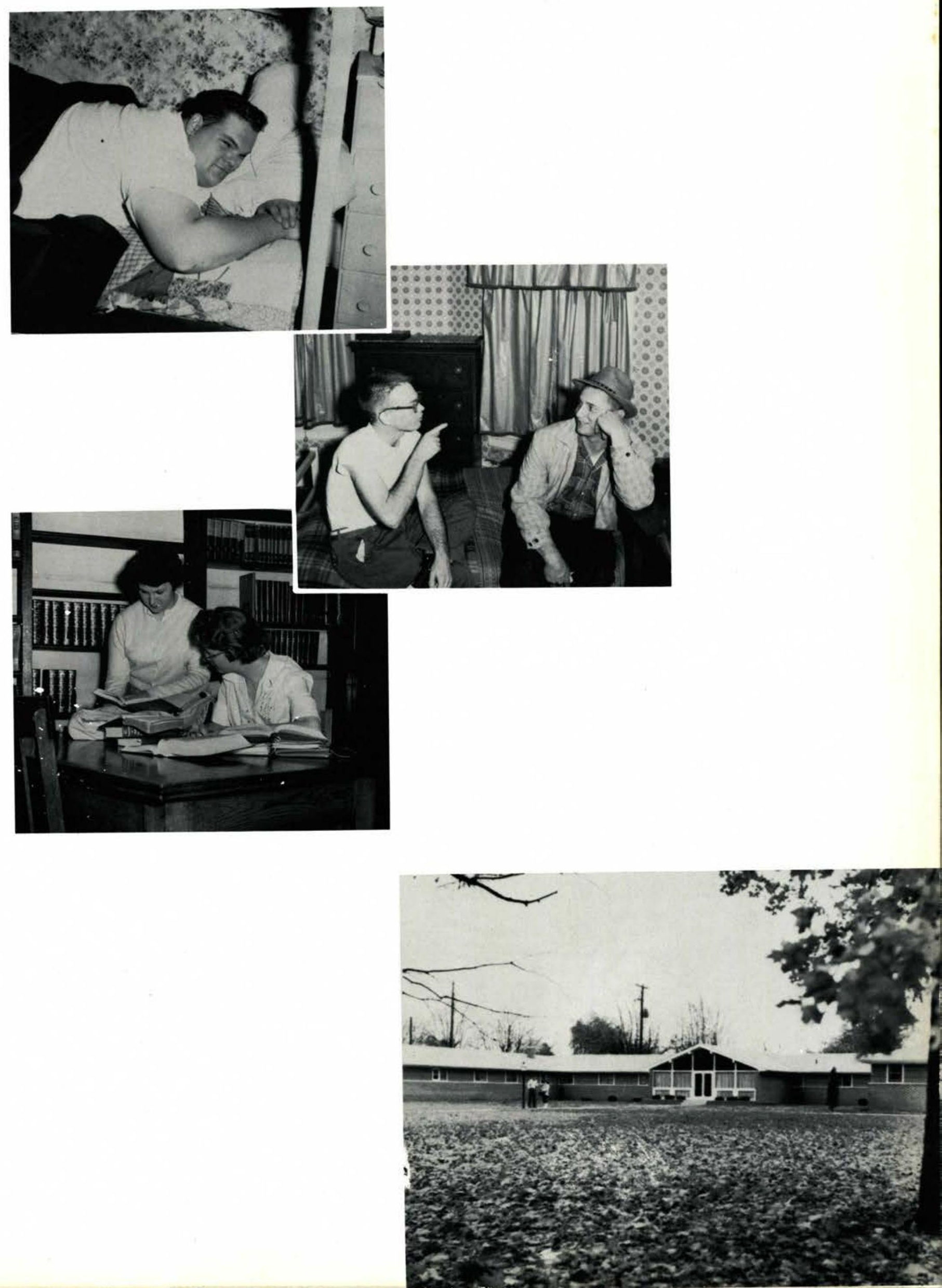

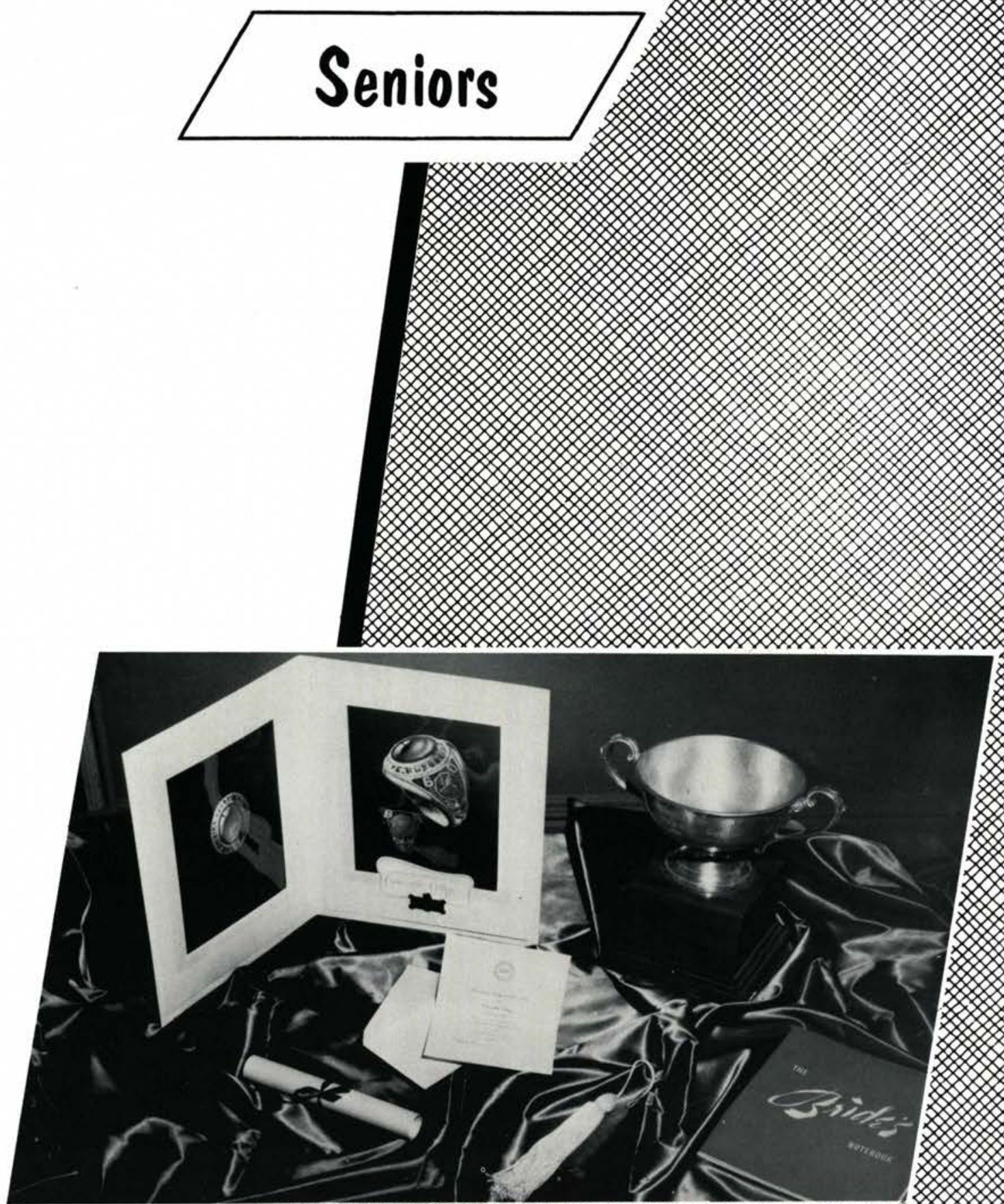

To God the glory, to men the Gospel. 
B.A.. History - Class President 2; Student Council, Vice-President 3, President 4; Discipline Committee 4; Alpha Chi Secretary-Treasurer 1; FWM, 3, President 4; Varsity " $\mathrm{C}$ " 2, 3, Co-Business Manager 4; Basketball Team 3; Baseball Team 1, 2, 3; Choir, 1, Student Manager 2, 3; Music Masters 3.

\section{PAUL HAROLD ANDERSON}

Ogden Dunes, Indiana

Miller Baptist Church
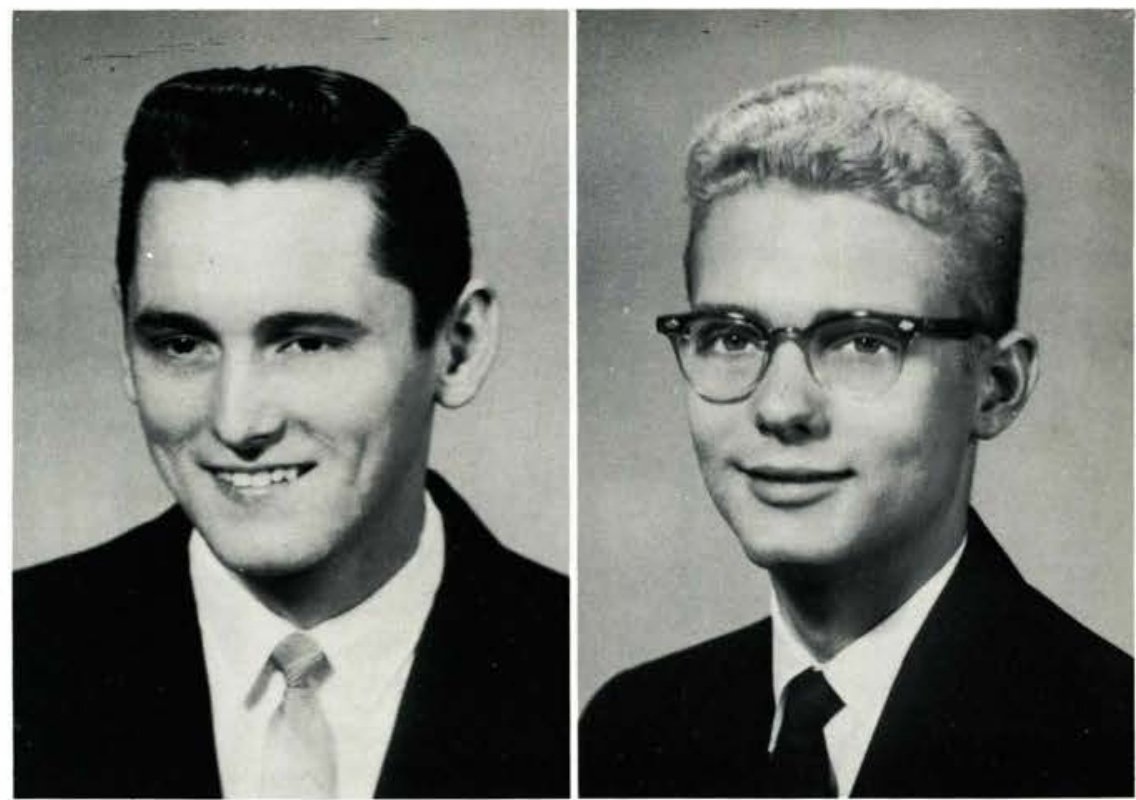

\section{HOWARD L. ANDRUS \\ Warren, Ohio}

Emmanuel Baptist Church

B.A., Bible.

\section{RUTH S. BOALT \\ Cleveland, Ohio \\ Bethlehem Baptist}

B.A., Social Science-Gamma Chi, 1, 2, Parliamentarian 3; Choir 2, 3; Music Masters 2; Quartette Pianist 2, 3; Trio Pianist 1.

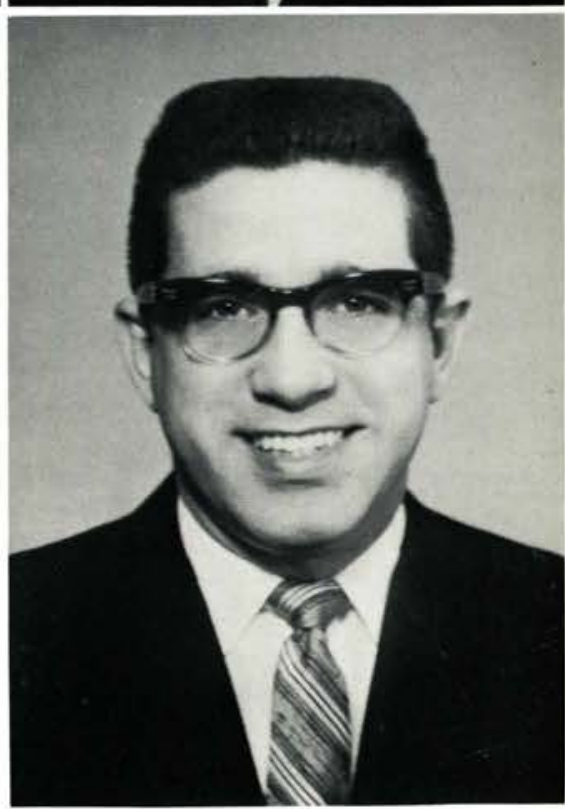

\section{ALBERTA L. CHAFFE}

Thompson, Ohio

South Madison Community Church

B.A.. English and Social Science - Gamma Chi 1, 3, Parliamentarian 2; Whispering Cedars Staff 2; Student Wives Guild, Treasurer 1, 2, 3, 4 .

\section{STUART L. CHAFFE}

Thompson, Ohio

South Madison Community Church

Senior Class Treasurer.

B.A.. Bible and History. 

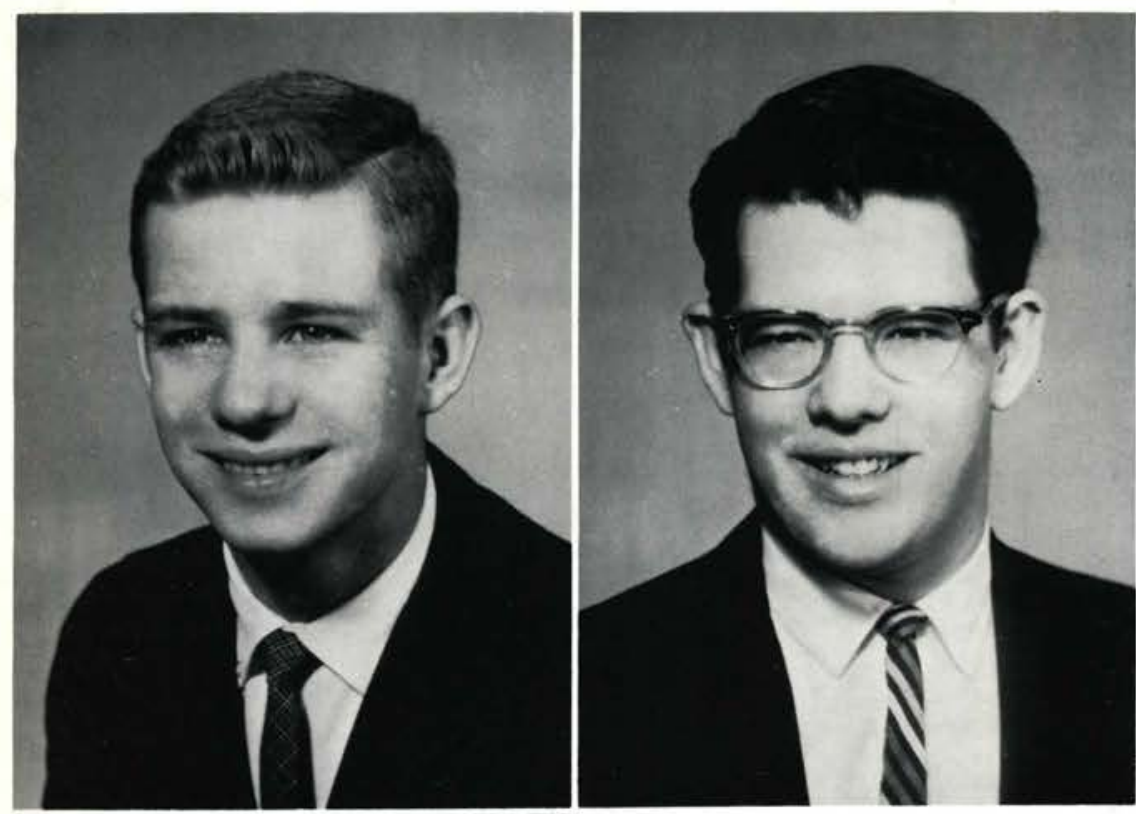

\section{KEITH ALLEN COLLETT \\ Inkster, Michigan}

Taylor Center Baptist Church

B.S.. Christian Education - Class President 3; Alpha Chi 2; Whispering Cedars Staff 2; Varsity " $\mathrm{C}$ " 2, 4, Treasurer 3; Tennis Team 2, 4, Captain 1; Choir 2; Band 1, 2, 3, 4; Quartette 1, 2, 3.

\section{HALL DAVID DAUTEL \\ Portsmouth, Ohio \\ Temple Baptist}

B.A., Social Science-Ohio University 55-56; Central State 59-60; Student Council 3; Varsity "C", 3, Vice-President 4; Basketball Team 2; Junior Varsity Coach 3; Baseball Team 1, 2, 3, 4.

\section{JACK DOWDEN}

Ames, Iowa

Campus Baptist Church

B.A., Bible - Iowa State University 56-58; Student Government 4; Alpha Chi 3, 4; Choir 3, Vice-President 4; Quartette 4.

\section{JOHN MARK ENTNER \\ Connersville, Indiana \\ Community Baptist Church}

B.S., Physical Science-Central State 59-60; Class Treasurer 2; Student Council, Treasurer 2, President 3; Discipline Committee 3; Alpha Chi 2, 3; Yearbook Staff 3; Varsity "C", 1, Chaplain 2, President 3, Co-Business Manager 4; Basketball Team 1, 2, 3, 4; Tennis Team 1, 2, 4.

\section{Seniors}

PHYLLIS JEAN ERNST

Fayette, Ohio

Ambrose Baptist Church

B.A., Music-Yearbook Staff 3; Women's Choir 1.

\section{WILLIAM STANLEY EVANS}

Columbus, Ohio

Memorial Baptist Church

Senior Class Vice-President

B.A., History - Whispering Cedars Staff 4 .

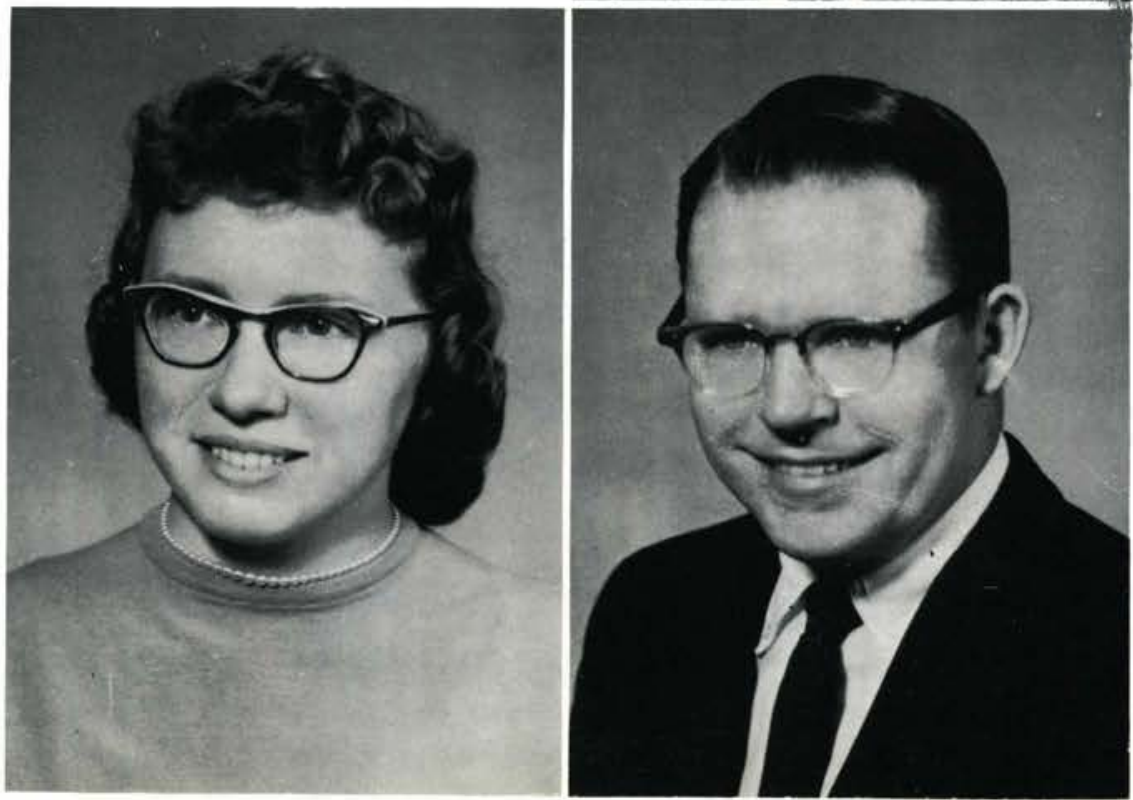



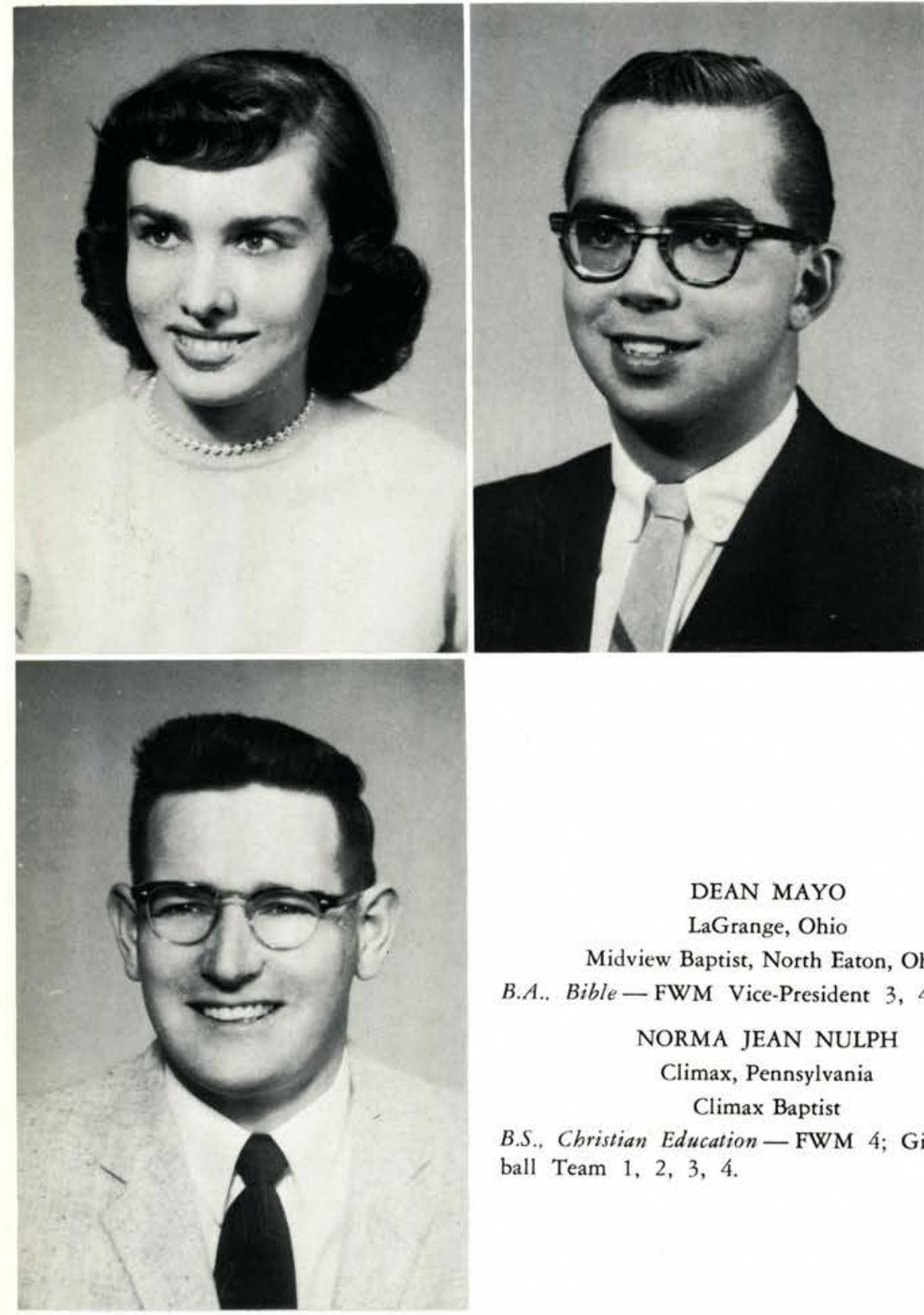

\section{LUCY LEE LYONS}

South Euclid, Ohio

Bethlehem Baptist Church

B.A., English - Student Council 2, 3, 4; Discipline Committee 4; Gamma Chi 1, Secretary-Treasurer 2, 3, 4; Yearbook Staff 2, 3; Choir 1, 2, 3, 4; Sextet 2; Women's Council 4.

\section{DAVID L. MATSON}

South Bend, Indiana

First Baptist, Mishawaka, Indiana

B.A., Music-University of Notre Dame 56-57; Alpha Chi 2, Parliamentarian 3, President 4; Sock 'n Buskin 3, Vice-President 4; Homecoming Play 3, 4; Yearbook Staff 3; Whispering Cedars Staff 2; Varsity "C" 3, Secretary 4; Basketball Team 2, Statistician 3, 4; Baseball Team Statistician 3, 4; Choir 2, 3, Student Director 4; Band 2, President 3, 4; Music Masters 2, 3 President 4; Trumpet Trio 2; Quartette 3; Sports Publicity Director 3, 4.

DEAN MAYO

LaGrange, Ohio

Midview Baptist, North Eaton, Ohio B.A.. Bible-FWM Vice-President 3, 4.

\section{NORMA JEAN NULPH \\ Climax, Pennsylvania \\ Climax Baptist}

B.S., Christian Education - FWM 4; Girls' Basketball Team 1, 2, 3, 4.

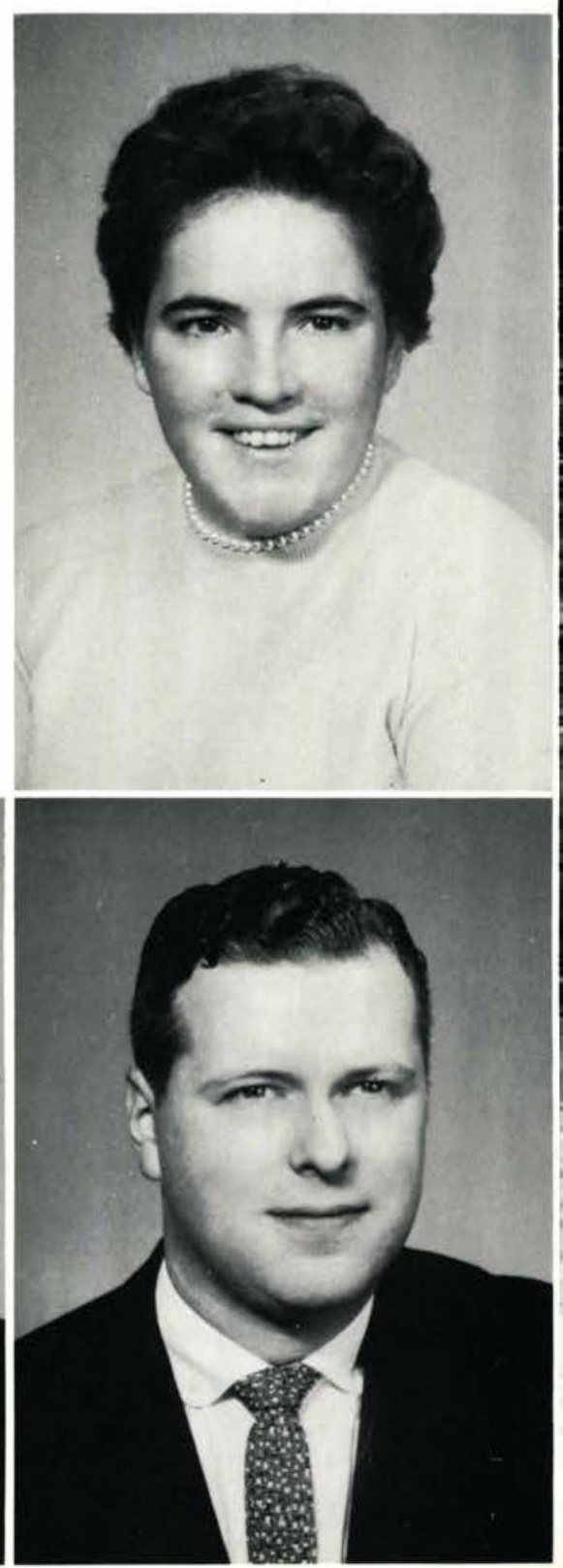

B.A., Bible - Indiana University 53-54; Class Chaplain 2, 4; Homecoming Play 2; Basketball Team 2; Choir 1, President 2; Quartet 1; Assistant Pastor, Sunbury, Ohio 4.

\section{B. WARREN PROUD}

Grand Rapids, Michigan

Immanuel Baptist, Xenia, Ohio

B.A. History and Bible - Wheaton College 51-53; Grand Rapids 54-58.

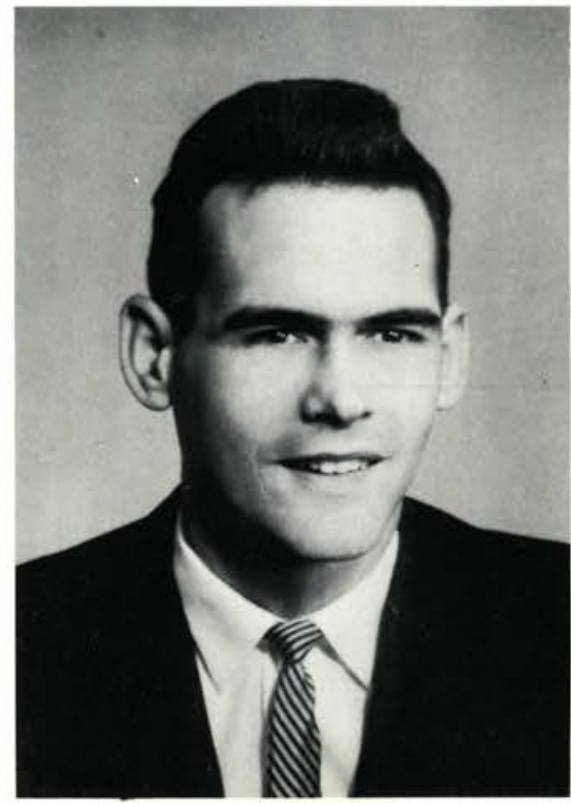




\section{PETE REESE}

Cedarville, Ohio

Clifton United Presbyterian

B.A., Physical Education - Varsity " $\mathrm{C}$ " 2, 3, Treasurer 4; Basketball Team 1, 2, 3, 4; Baseball Team 1.

\section{SALLY ROUDYBUSH}

Butler, Pennsylvania

Worthington First Baptist

B.A., English - William Jennings Bryan College 55-57; Gamma Chi 3, 4; Homecoming Play 3; Whispering Cedars Staff 4; Band 3.

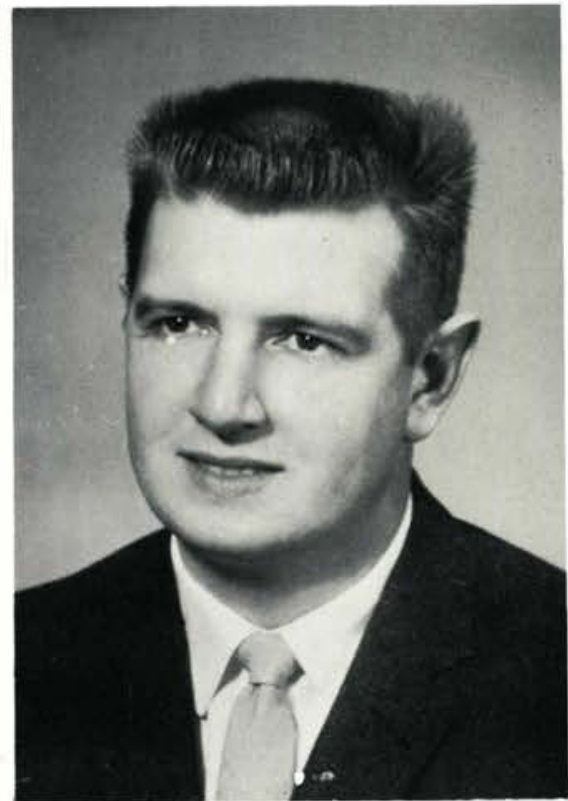

B.A., History - Flint Junior College 56.57.

\section{DONALD SEWELL}

Williamsburg, Ohio

First Baptist Williamsburg

B.A., Bible - Tennessee Temple College 57.58; Student Pastor, Williamsburg, Ohio

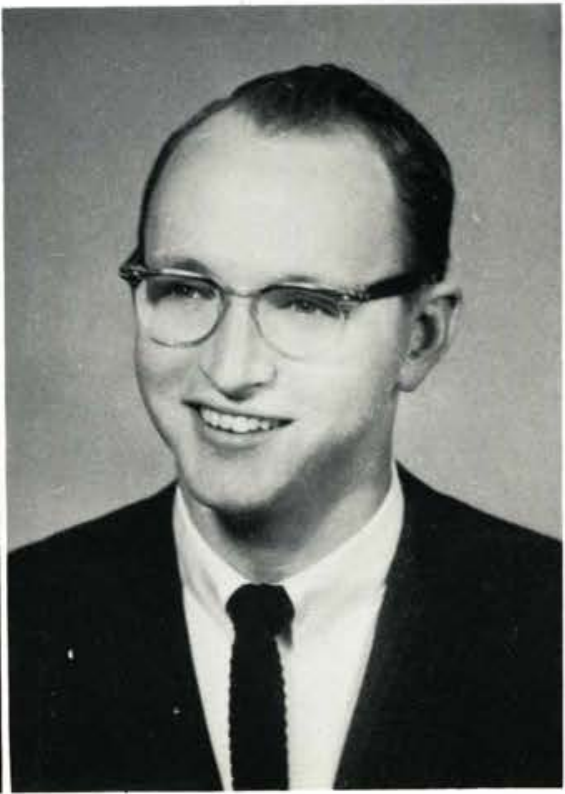

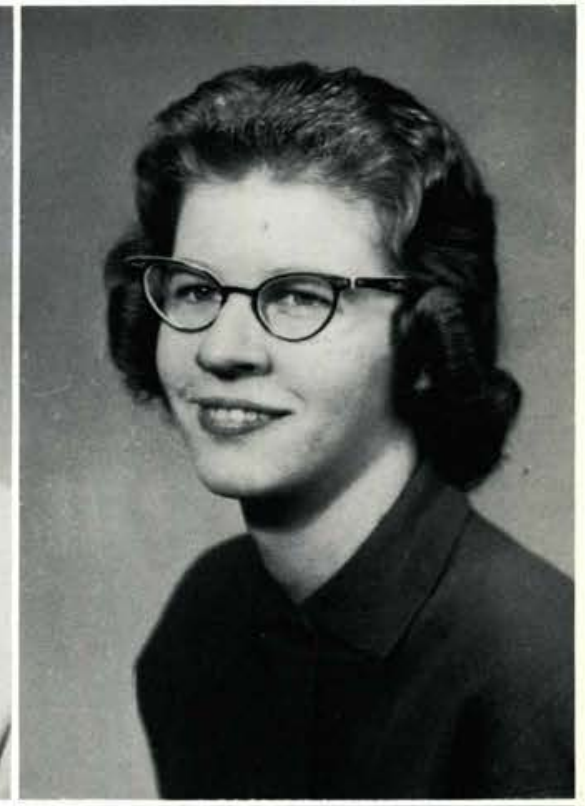

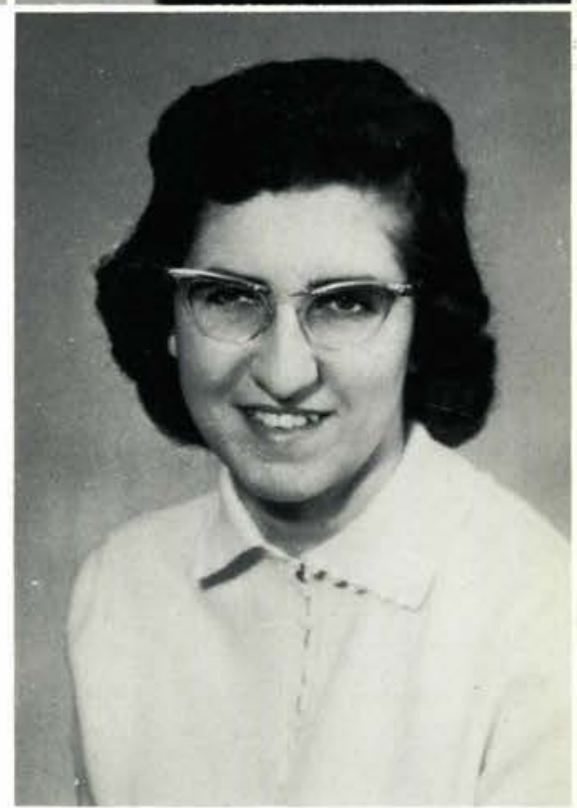

\section{ARTHUR RAY SHEPHERD}

Cincinnati, Ohio

Norwood Baptist

B.A., Bible - University of Cincinnati 55-56, Tennessee Temple College 57-58, University of Cincinnati Summer School 58; Class Chaplain 3; Senior Ring Committee Chairman; Alpha Chi 3, Chaplain 4; FWM 4; Choir 3, 4; Director City Gospel Mission, Cincinnati, Ohio.

\section{LARRY DEAN SMITH}

Moweaqua, Illinois

Riverside Baptist, Decatur, Illinois

Senior Class President

B.S.. Biological Science-Class Parliamentarian 2, 3; Student Council 4; Yearbook Staff Editor 3. 

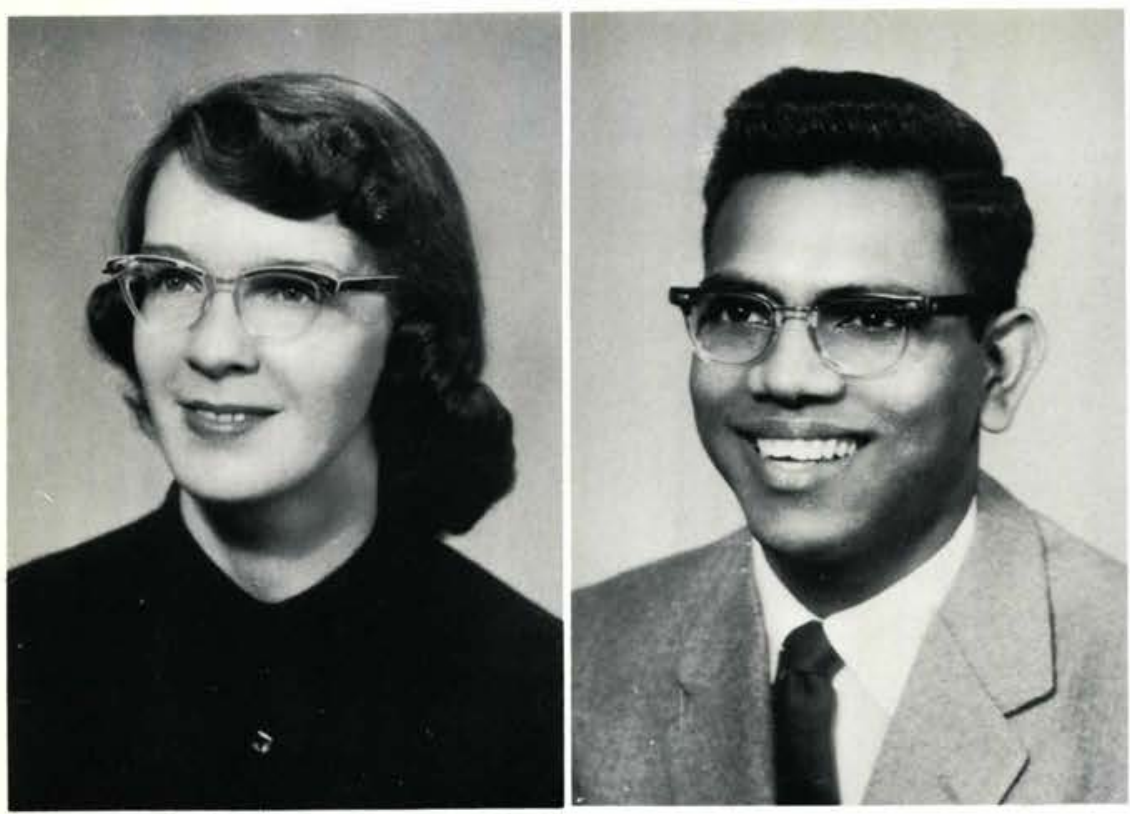

\section{ROSEMARY SMITH}

Kirkersville, Ohio

Reynoldsburg Bible Mission Baptist Church Senior Class Secretary

B.A., Physical Education-Class Secretary 3; Student Council 4; Student Government 4; Gamma Chi 2, 3, 4; Sock 'n Buskin 3, 4; Homecoming Play 2, 3, 4; FWM 3; Girls' Basketball Team 2, 3, 4; Choir 1, 2, Secretary 3, 4; Band 1, 2, 3, 4; Cheerleader 2, 4; Sextet 2; Girls' Quartette 4.

HUBLALL A. SOOKRAM

Corentyne, British Guiana, S.A.

First Regular Baptist

B.A., Social Science-FWM 1, 2, 3, 4.

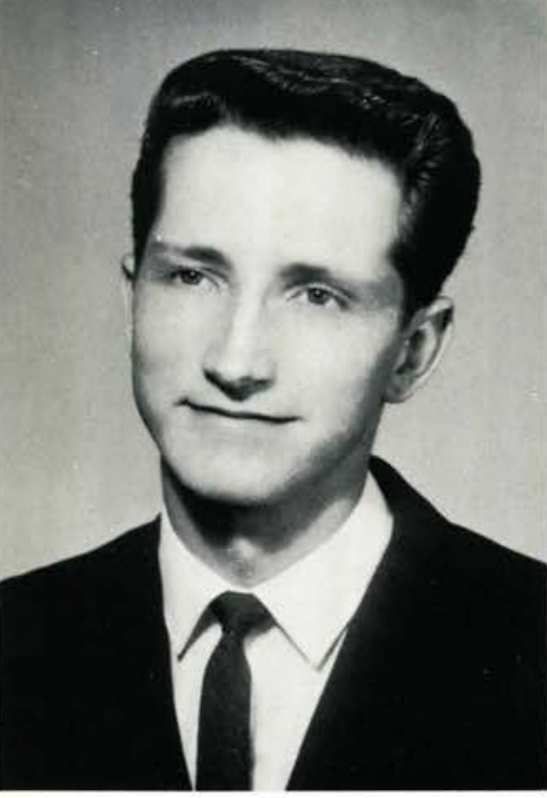

WARREN W. WOODARD

Jamestown, New York

Chandler Street Baptist Church

A.B., General Science-Class Vice-President 3,

Treasurer 1; Alpha Chi 1, 2, 3; Yearbook Staff 2,

3; Basketball Team 1; Tennis Team 2, 3; Choir 1, 2,

3; Quartet 2, 3, 4 .

\section{Seniors}



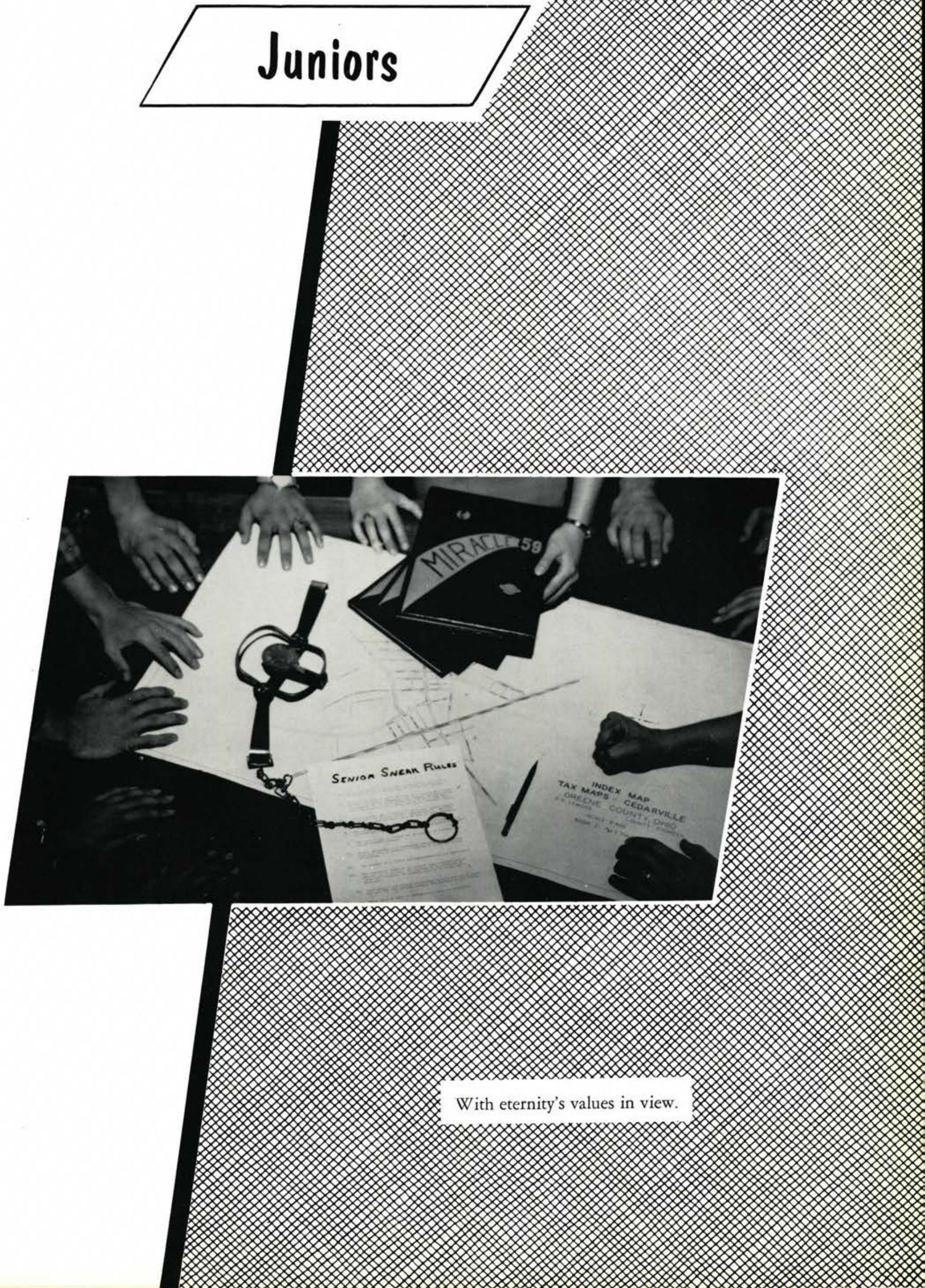

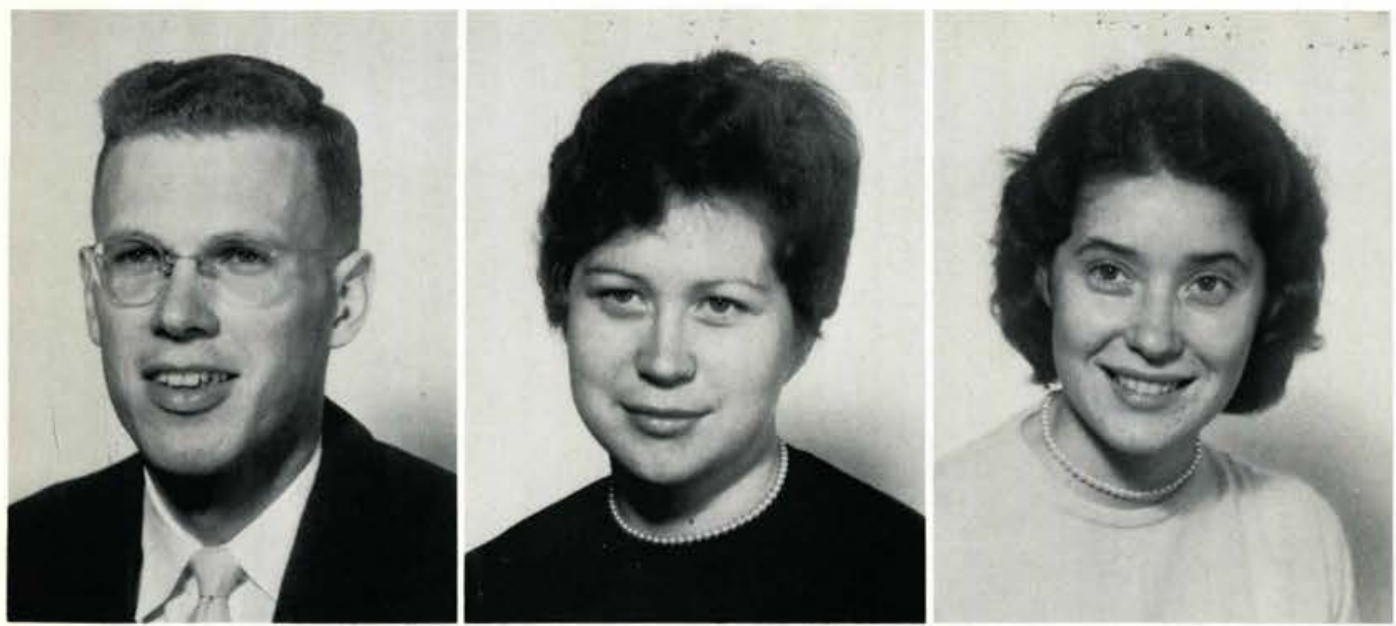

John Butler, Vice President Greene, Iowa

Alameda Baptist Church

Neva Voss Claypool

Kittanning, Pennsylvania

Old Union Baptist Church

Donis Collier

Moweaqua, Illinois

Grace Baptist Church
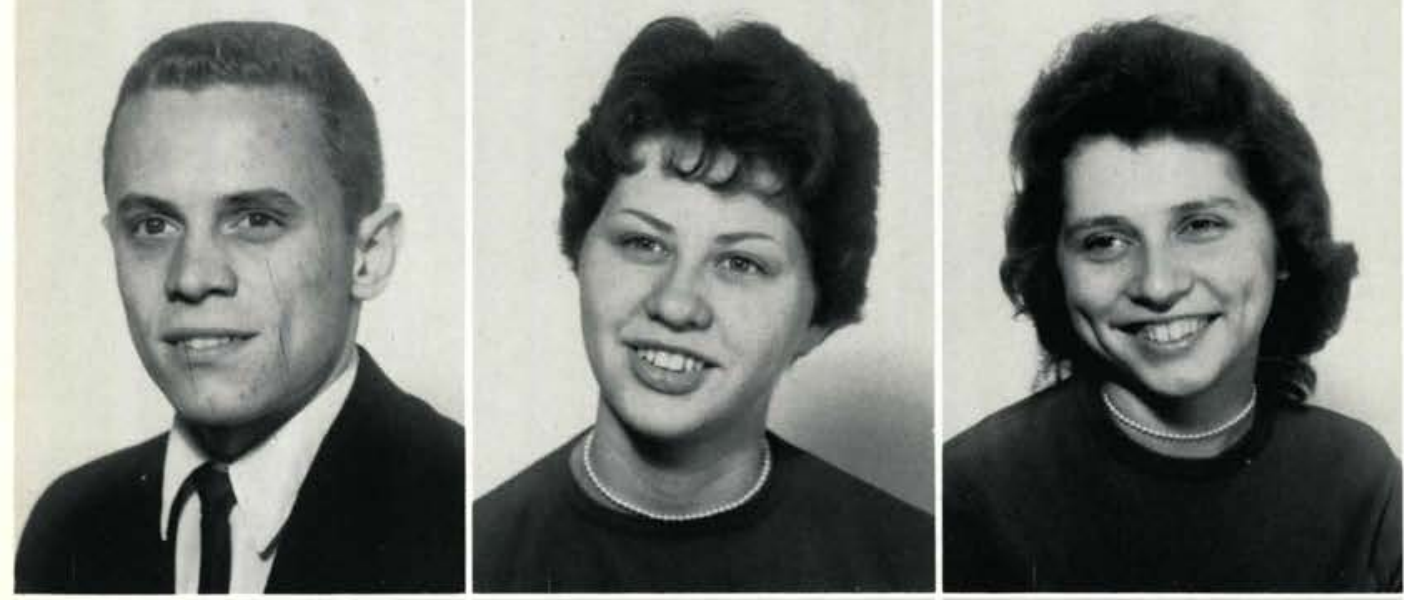

Dick Cook

Flint, Michigan

Riverdale Baptist Church

Marcia Gail Crothers

Lakeville, Indiana

First Baptist of Plymouth

Marlene Davis, Secretary

Parma, Ohio

First Baptist Church

Phyllis Dobbs

Kuna, Idaho

First Baptist Church

Kenneth Doctor

Ellsworth, Michigan

Eastport Baptist Church:

Lois Dodson

Winona Lake, Indiana

Fellowship Baptist Church

James Entner

Connersville, Indiana

Community Baptist Church

Norman Getty, President

Cedarville, Ohio

Blessed Hope Baptist Church

Terry Goodrich

Boise, Idaho

Temple Baptist Church 
Joyce Grant

East Moline, Illinois

Third Street Baptist Church

Ronald Hall

Bedford, Ohio

Bible Baptist Church

Shirley Harrington

Kankakee, Illinois

First Baptist Church

Frank A. Howard

Cedarville, Ohio

Grace Baptist Church

Barbara Johnson

Poland, Ohio

Struthers Baptist Tabernacle

Earnajean Lockerbie

Seattle, Washington

Brooklyn Baptist Church

Nancy McDivitt

Garrettsville, Ohio

Troy Baptist Church

James R. Neely

Deerfield, Illinois

Community Baptist Church

Delores Osborn, Treasurer

Westminster, Colorado

First Baptist of Westminster

James D. Parker

Chillicothe, Ohio

Eden Baptist Church

Pat Petry

New Madison, Ohio

Immanuel Baptist Church

Lon Reising

Chesterfield, Missouri

Lackland Road Baptist Church
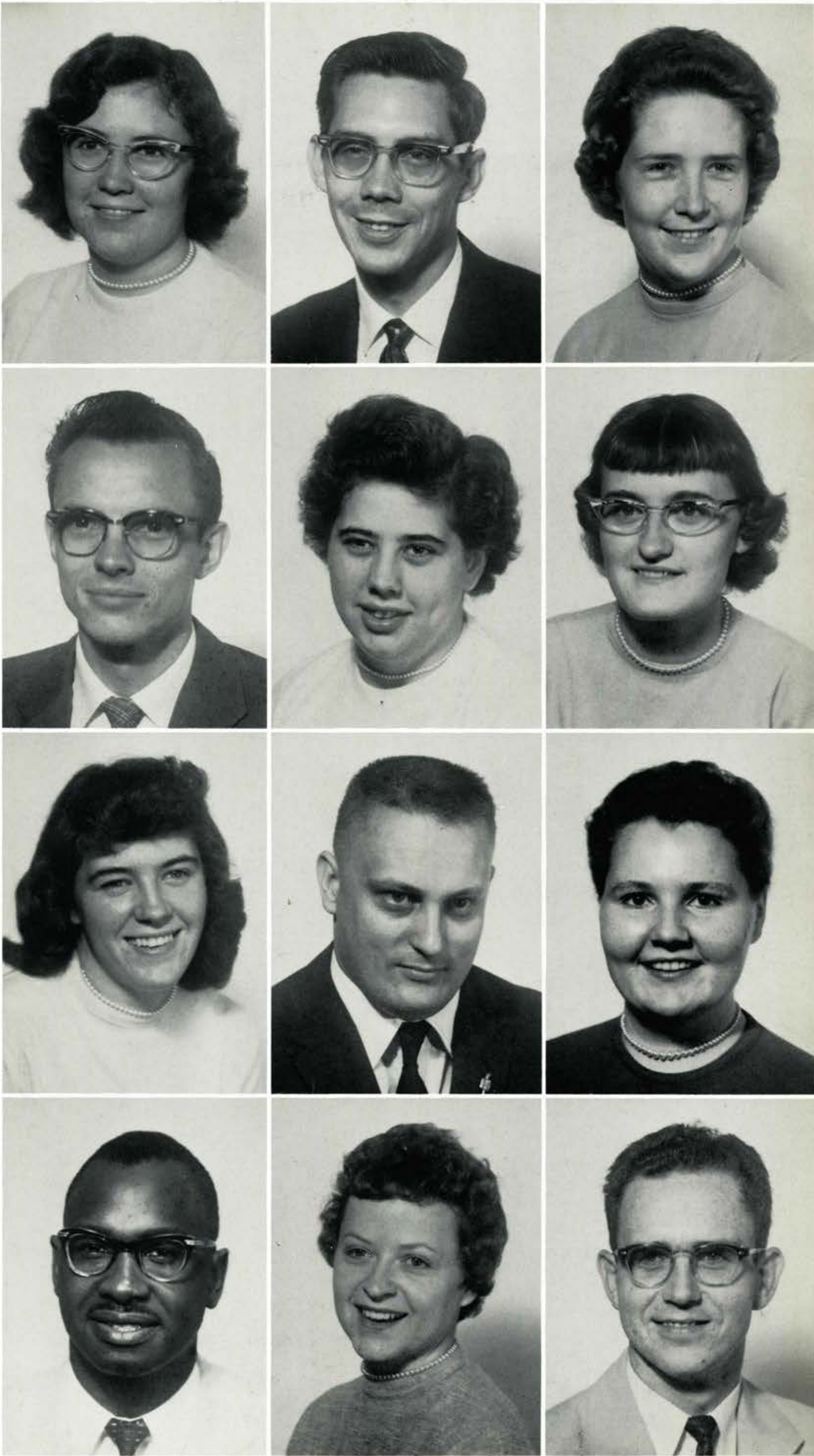

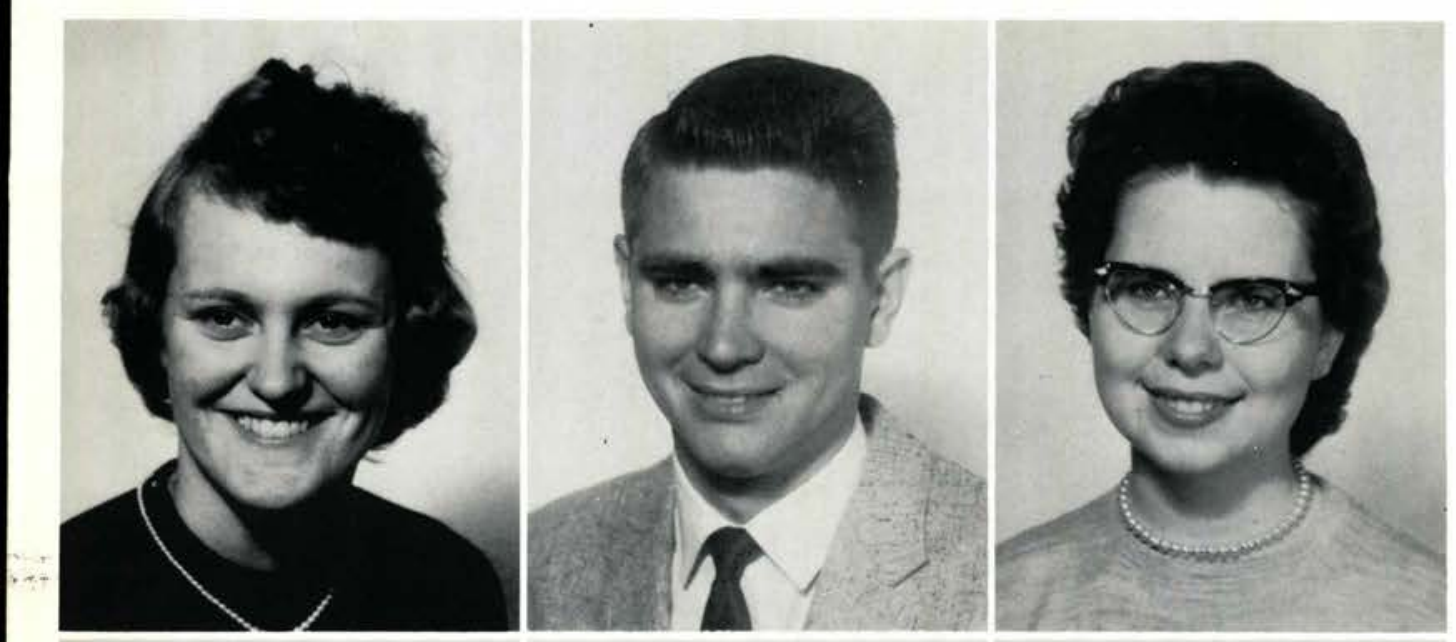

Joan Reiter

Southold, Long Island, New York

Bible Baptist Church

Louis J. Schramm

Romeo, Michigan

First Baptist Church

Helen L. Stevens

Boise, Idaho

Whitney Baptist Church
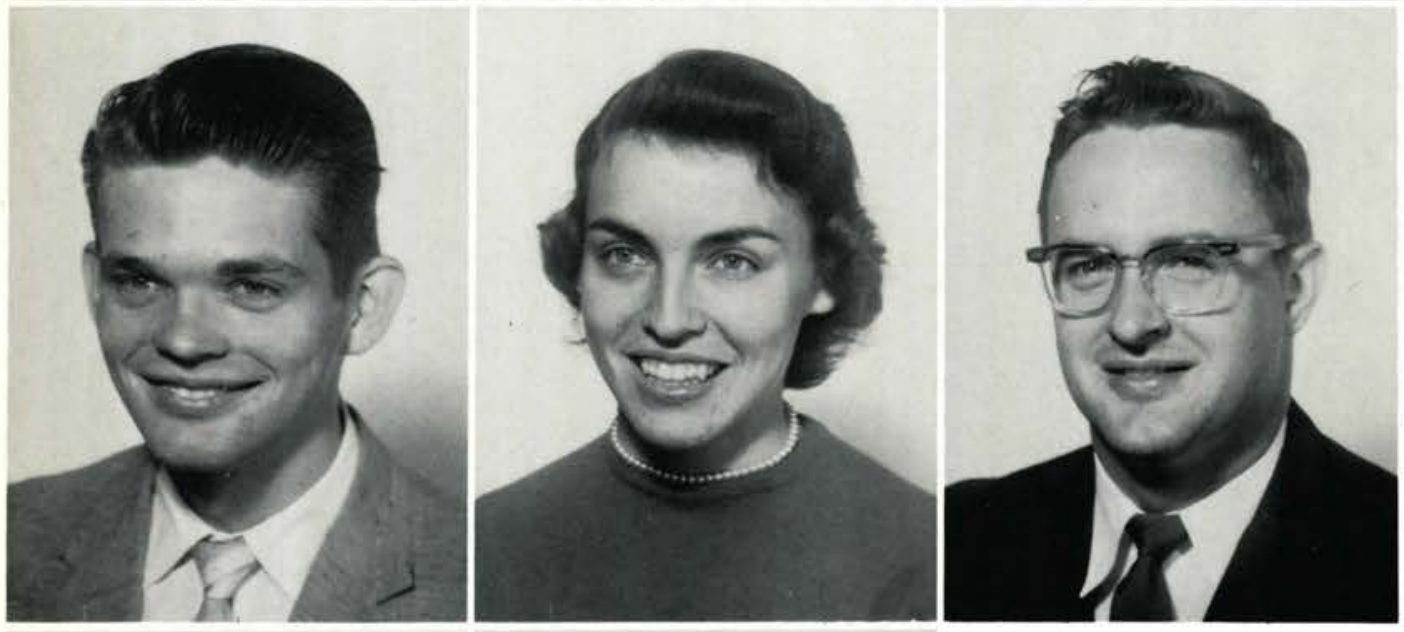

Horace Ward, Jr.

Cedarville, Ohio

Pentecostal Church of Christ

Esther Weiss

Farview Park, Ohio

Berea Baptist Church

Dean A. Zerby

Berrien Springs, Michigan

Memorial Baptist Church

Terry K. Zerby

Berrien Springs, Michigan Berrien Center Community Bible Church

Carol Ann Zoellner

Sandusky, Ohio

Woodlawn Baptist Church

Pictures Not Available

Tom McManus

Leon Rowland, Chaplain

Barbara Sherry 

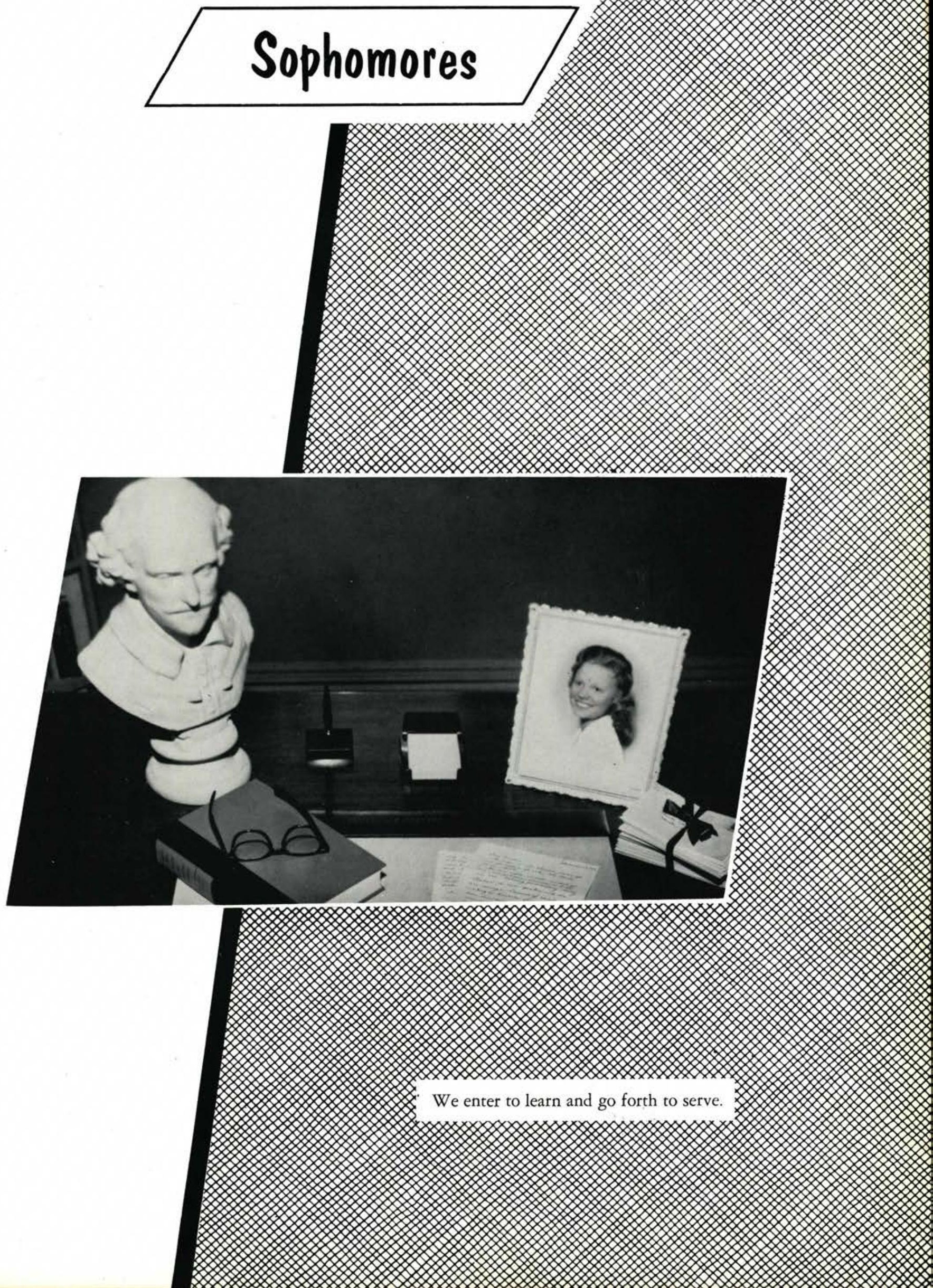


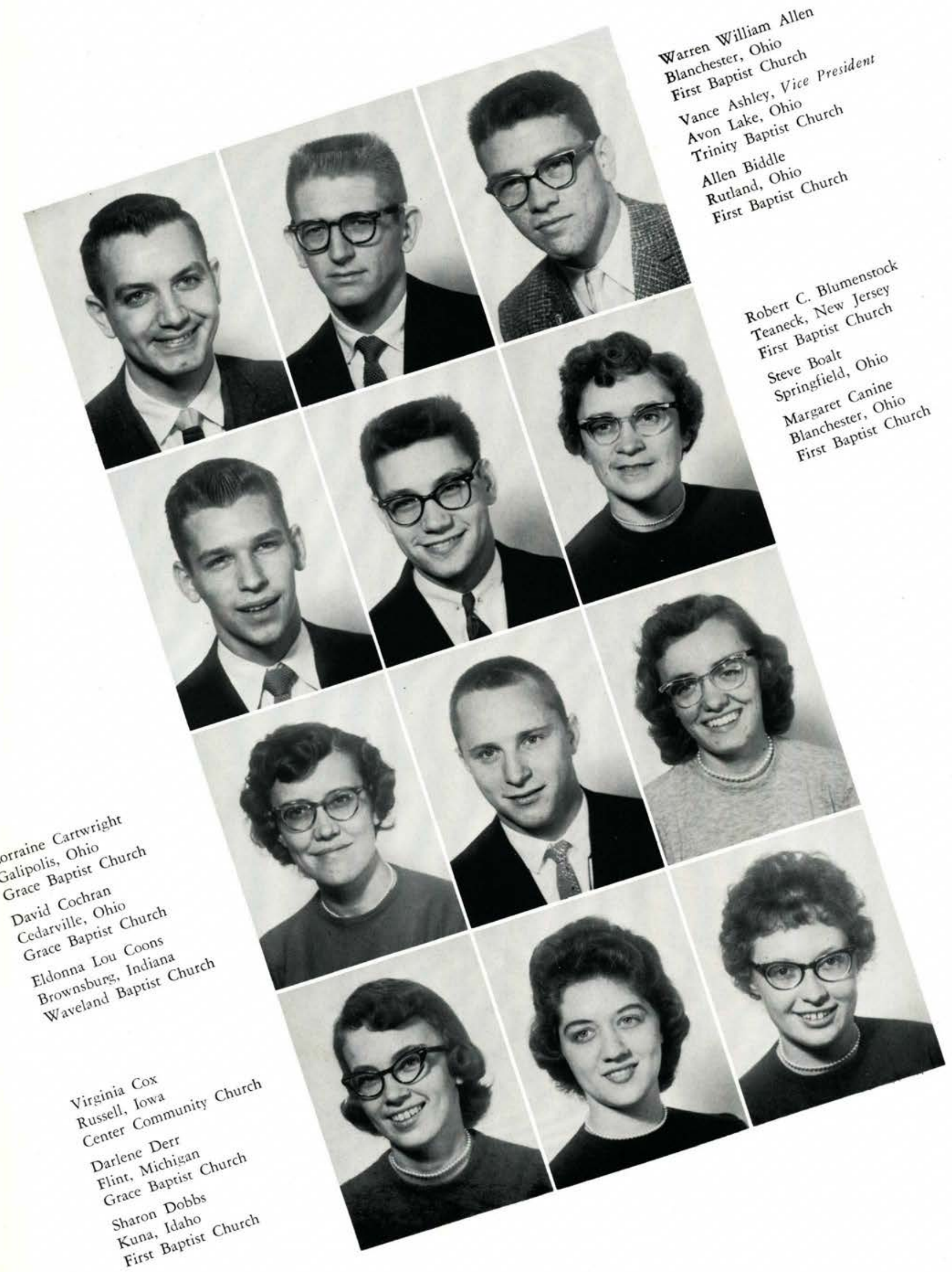




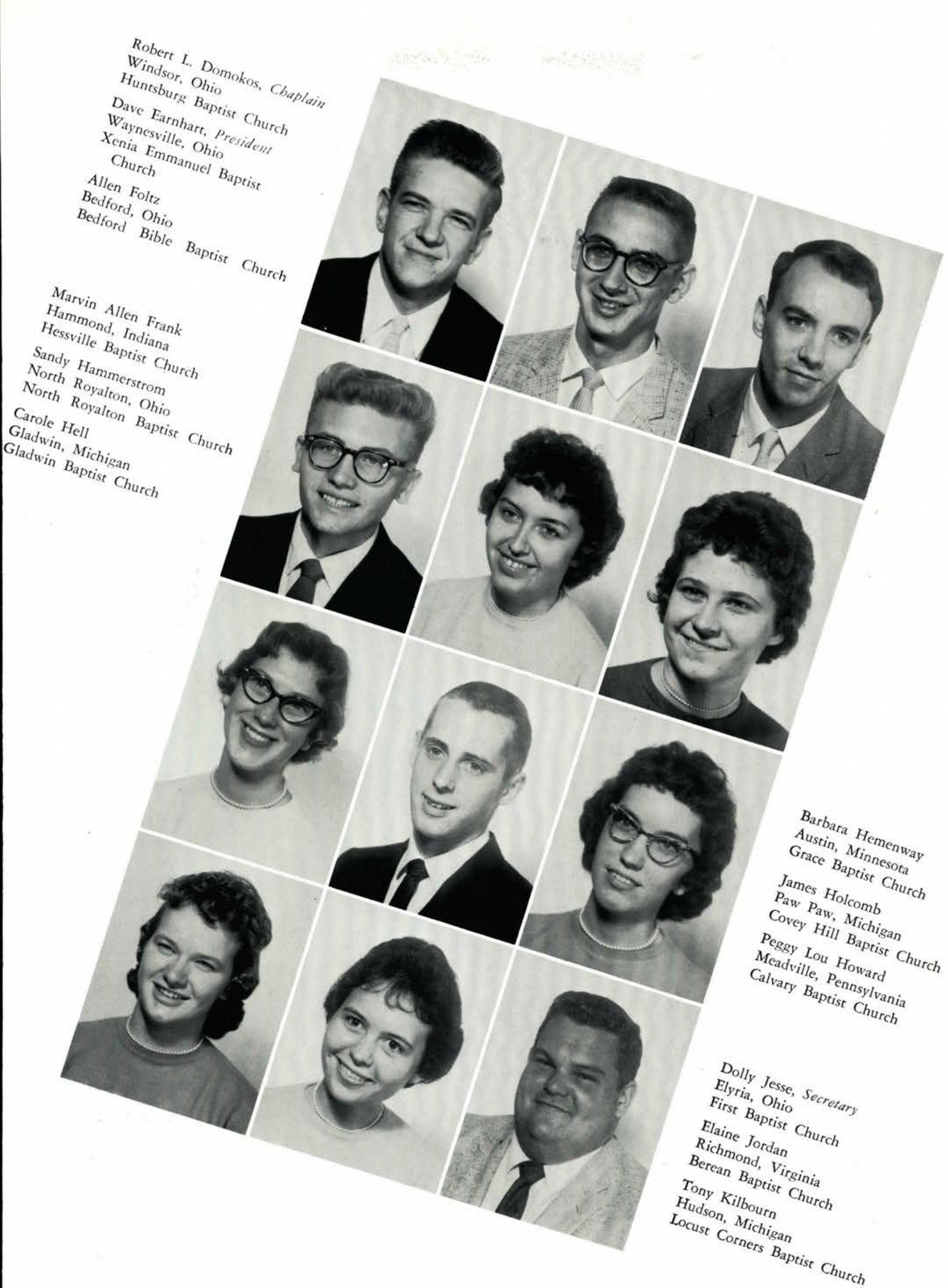




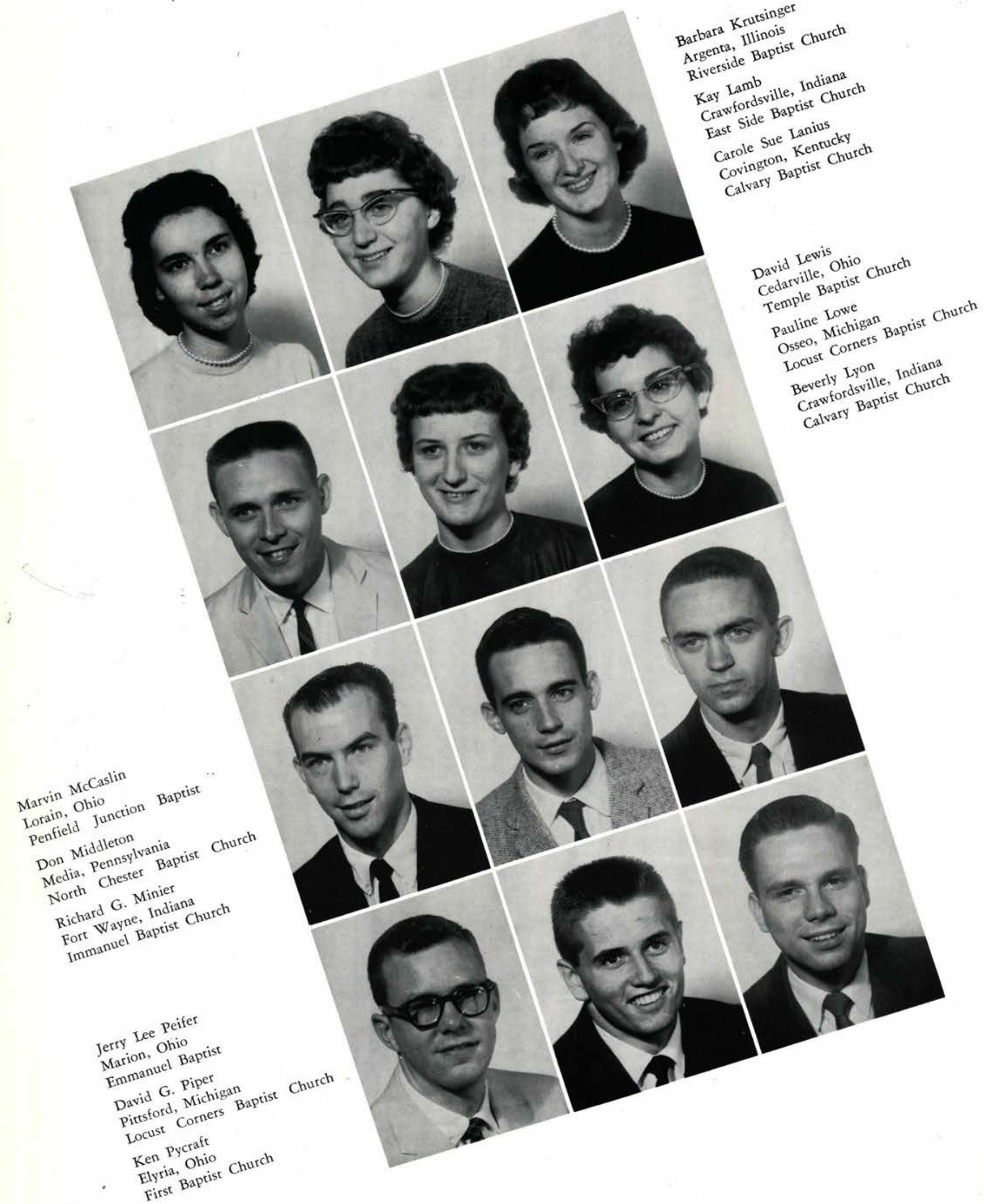




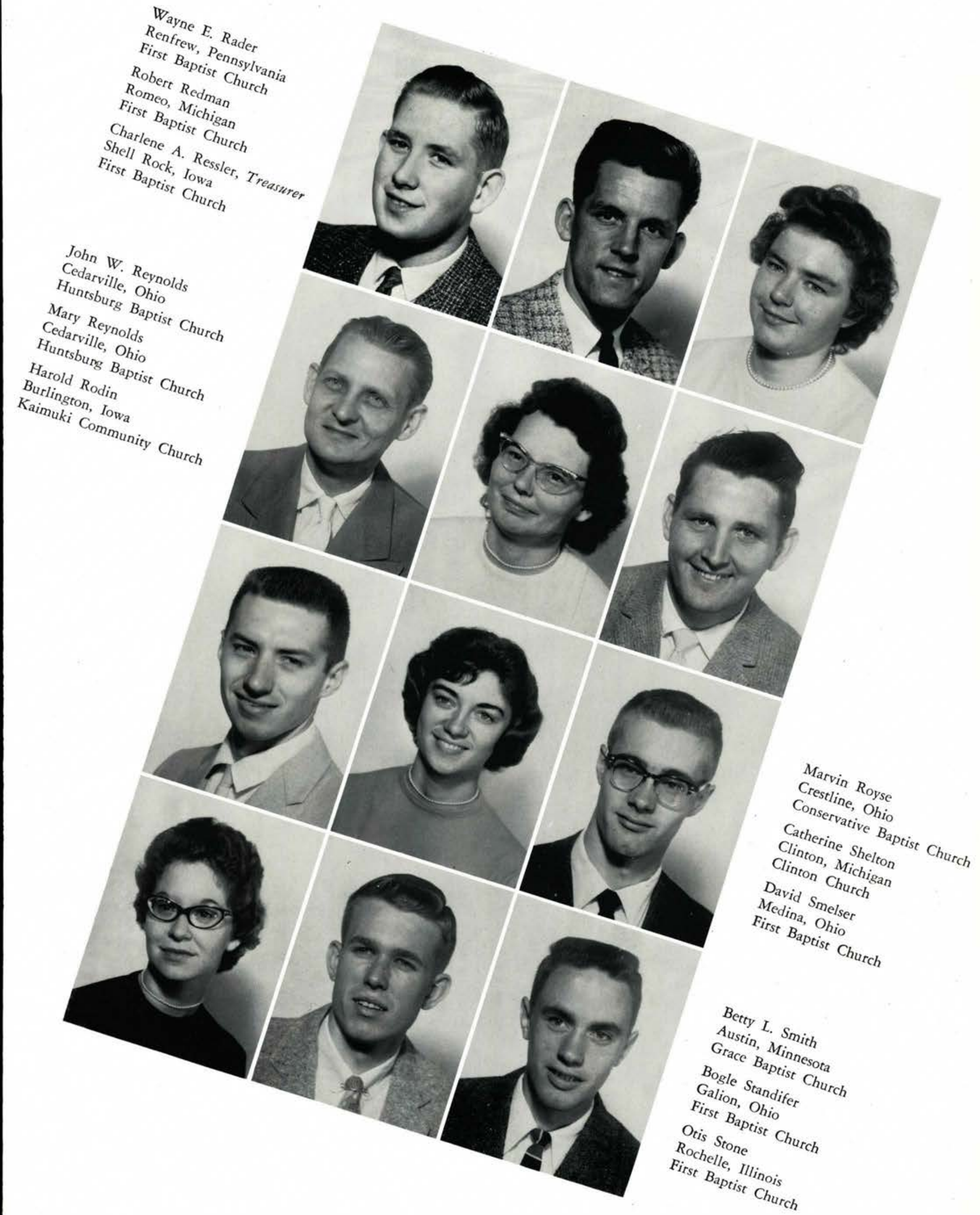




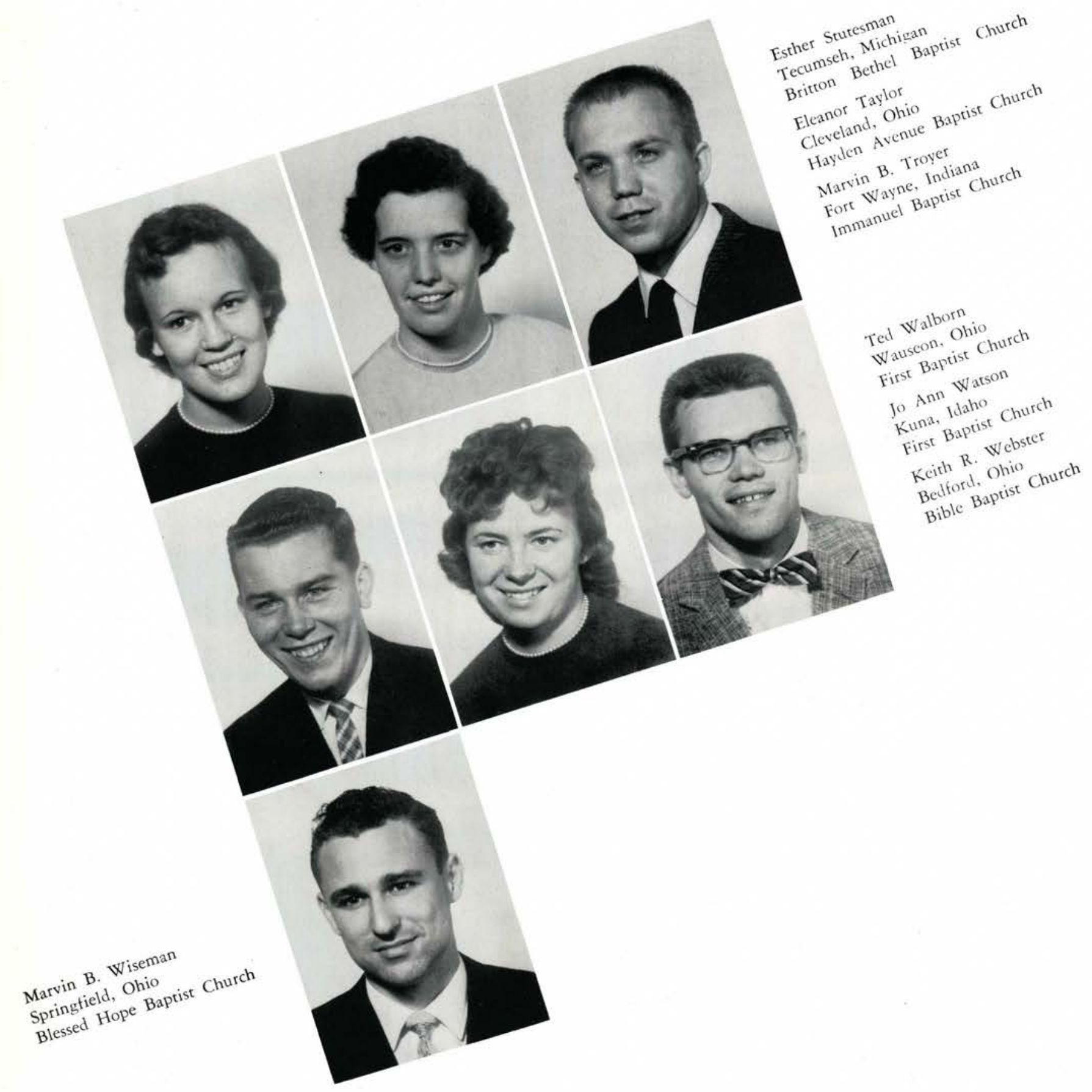

Pictures Not Available

David Burgess

Gene Evans

Chuck Taylor

Donley Tennant 

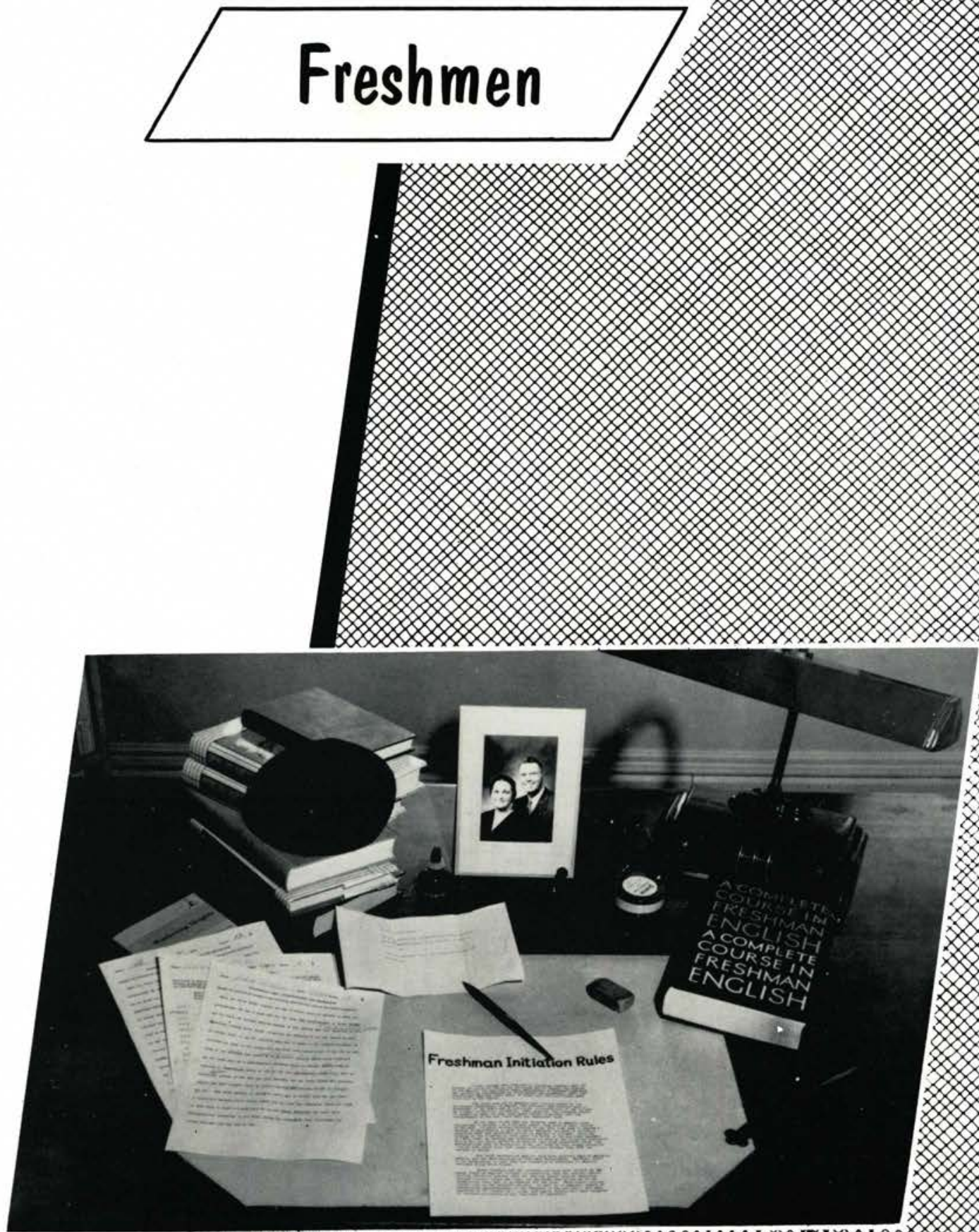

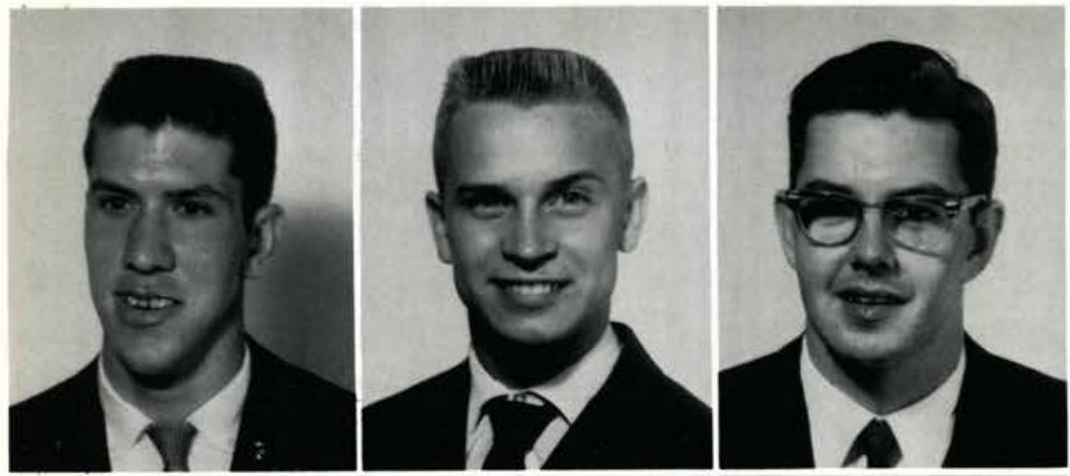

Donald Adams

East Moline, Illinois

Third Street Baptist Church

Neal Amstutz

Fairborn, Ohio

Trinity United Church of Christ

Fred Banfield

Chesterland, Ohio

Riverview Bible Church
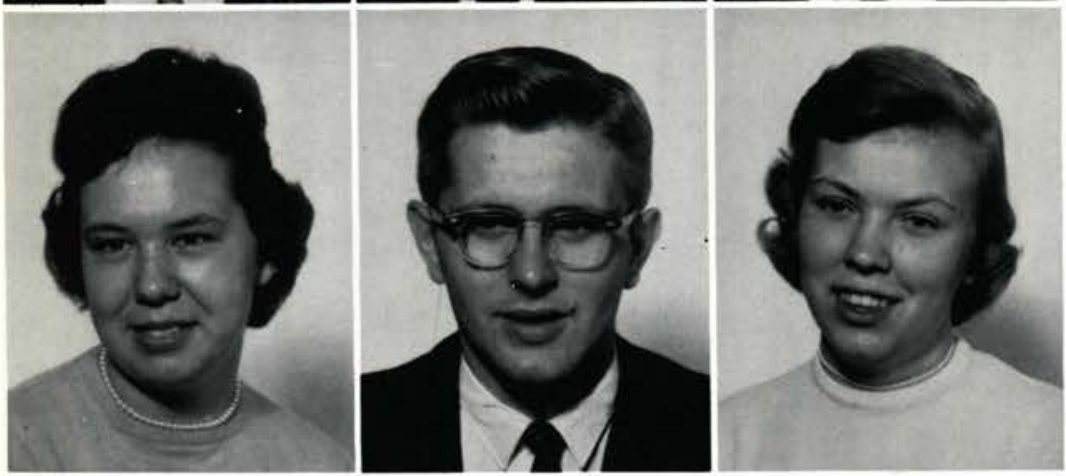

Gweneth Bennett

Kuna, Idaho

First Baptist Church

Lee Bennett

Freeport, Pennsylvania

Willoughby Baptist Church

Irene Benson

Gary, Indiana

Central Baptist Church

A. Leigh Betts

Rochester, Minnesota

First Baptist Church

Julia Bird

Saline, Michigan

York Baptist Church

Rodney Bissell

Massena, Iowa

Massena Baptist Church

Richard Blumenstock Teaneck, New Jersey First Baptist Church

Edward Bohling

Gary, Indiana

Miller Baptist Church

Carole Ann Boren

Niles, Ohio

First Baptist Church

Daniel A. Brower

Dewitville, New York Mayville Baptist Church

Philip Brower

Kalkaska, Michigan

Kalkaska Baptist Church

Carol Ann Brown

Sycamore, Ohio

Tiffin Calvary Baptist Church
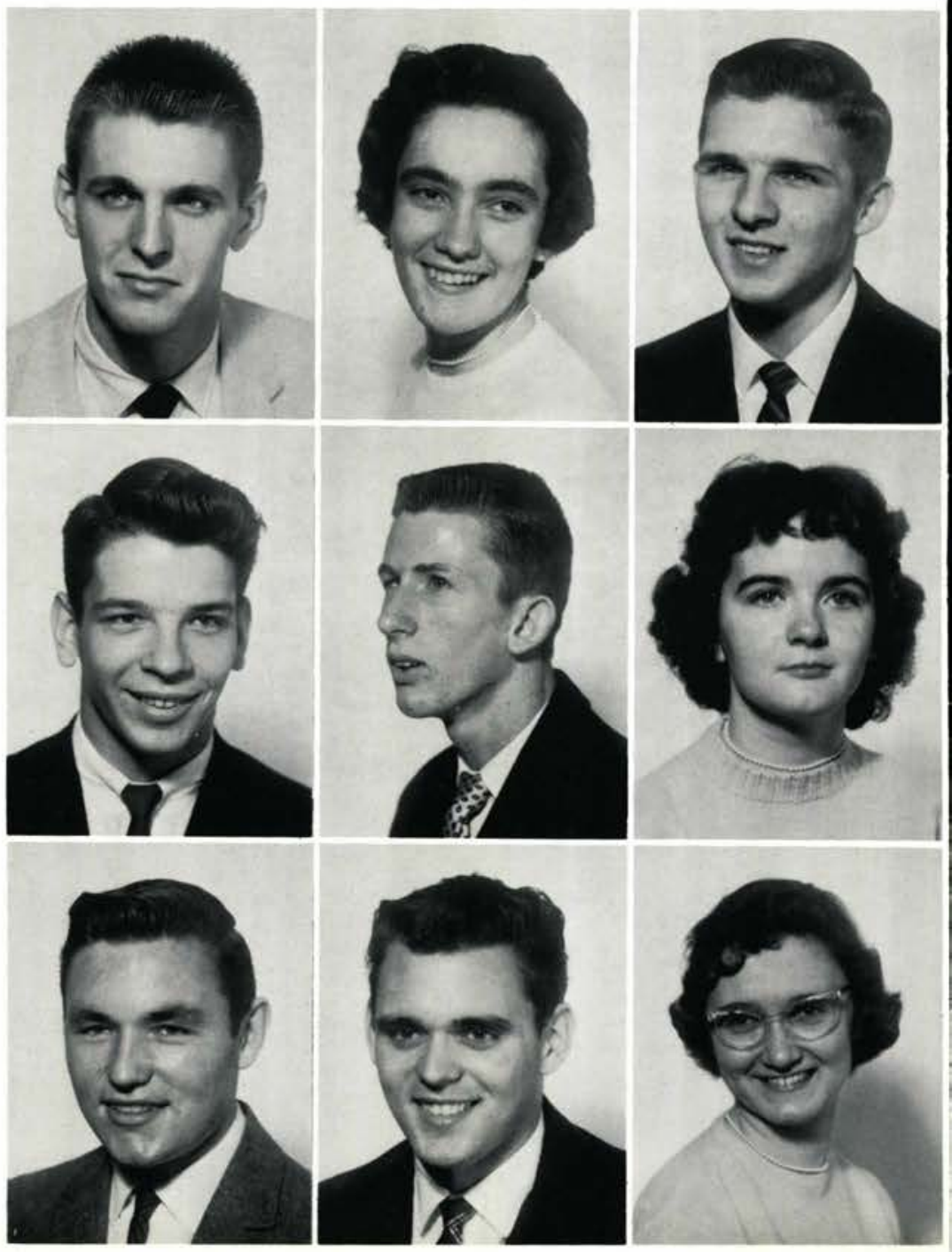

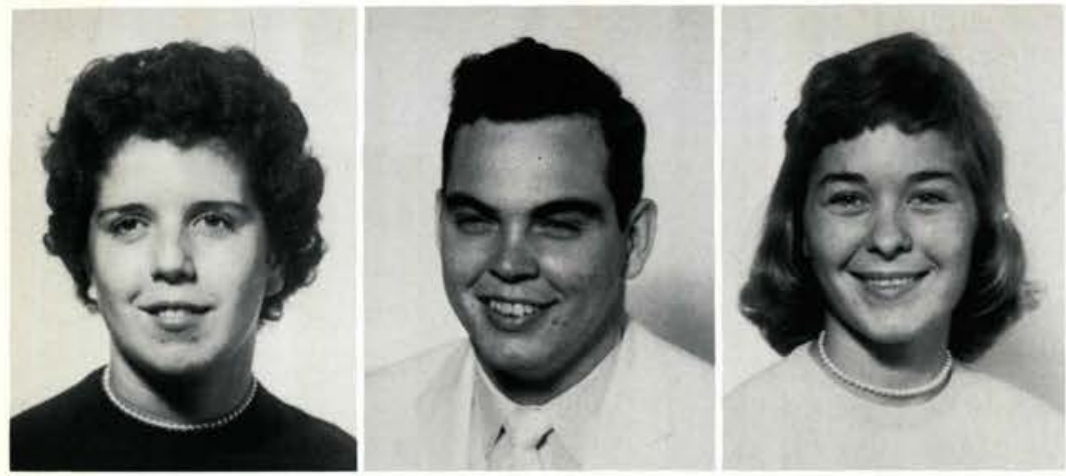

Henrietta M. Davis

North Adams, Michigan

North Adams Baptist Church

John W. Donaldson

Rochelle, Illinois

First Baptist Church

Jeannie DuPre

Washington, District of Columbia

Capitol Baptist Church
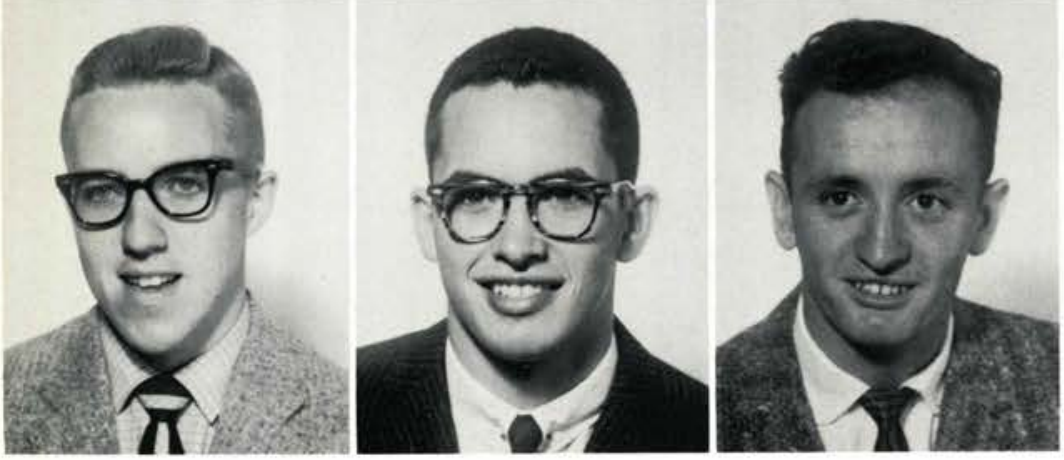

Edward Eastman

Wiscasset, Maine

Bible Baptist Church

Bill Elder

Bucyrus, Ohio

Emmanual Baptist Church

Leon E. Farnsworth

Jerome, Michigan

North Adams Baptist Church

Joe Ferrell

Covington, Kentucky

Calvary Baptist Church

Robert Fidler

Gary, Indiana

Central Baptist Church

Donna Finley

Faribault, Minnesota

First Baptist Church

Priscilla Fleming

Gary, Indiana

Brunswick Baptist Church

Kay Gallaspie

Lima, Ohio

South Lima Baptist Church

Paul Gathany

Randolph, New York

Randolph Baptist Church

Peg Getty

Elyria, Ohio

First Baptist Church

Ramona Jane Ginz

Peoria, Illinois

Germantown Baptist Church

June Ellen Golden

Stanton, Michigan

First Baptist Church
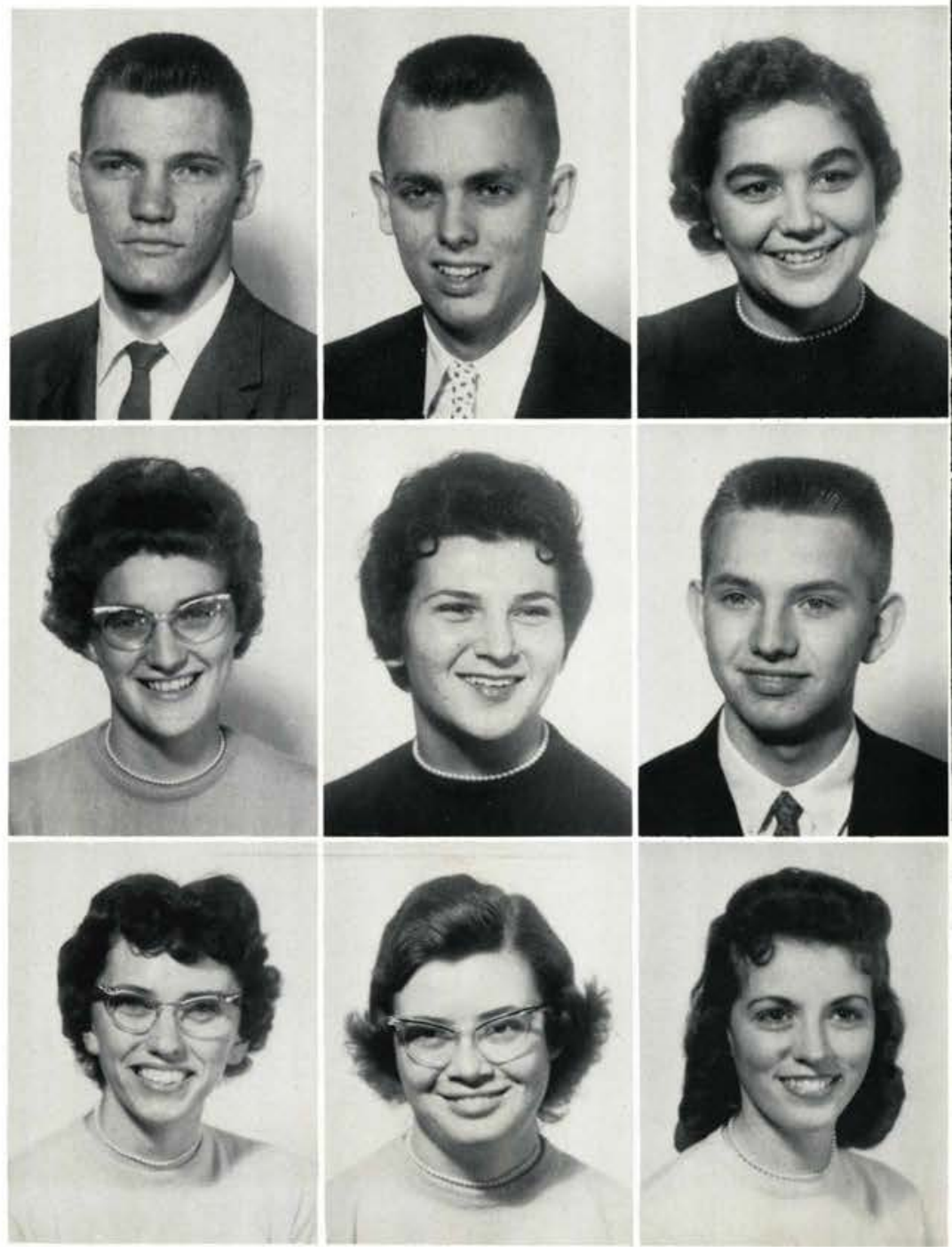
James Grafton

Worthington, Pennsylvania

First Baptist Church

Phillip R. Grant

East Moline, Illinois

Third Street Baptist Church

John P. D. Graydon

Cleveland, Ohio

Bethel Baptist Church

Sue Hacker

Willoughby, Ohio

Euclid Nottingham Baptist Church

Brian Hall

Kalkaska, Michigan

Kalkaska Baptist Church

Charles Hartzell, President

Butler, Pennsylvania

First Baptist Church
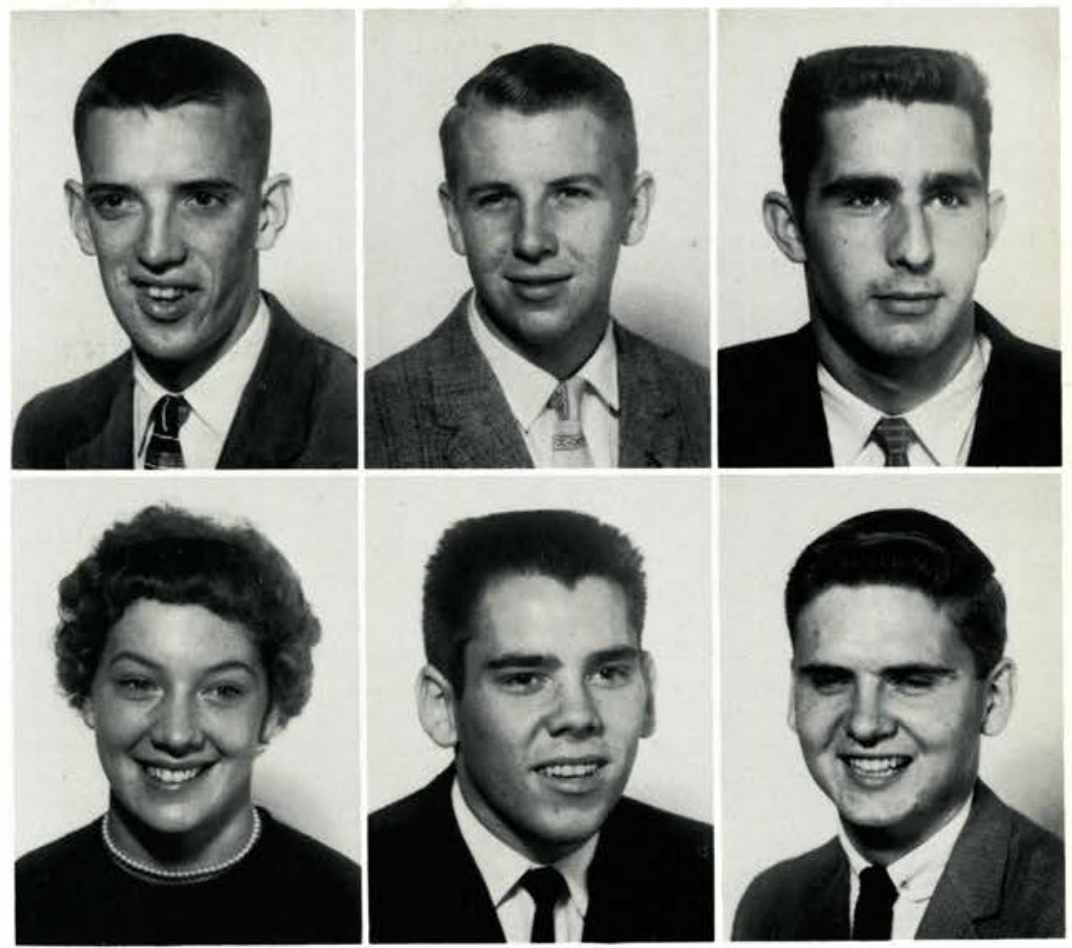
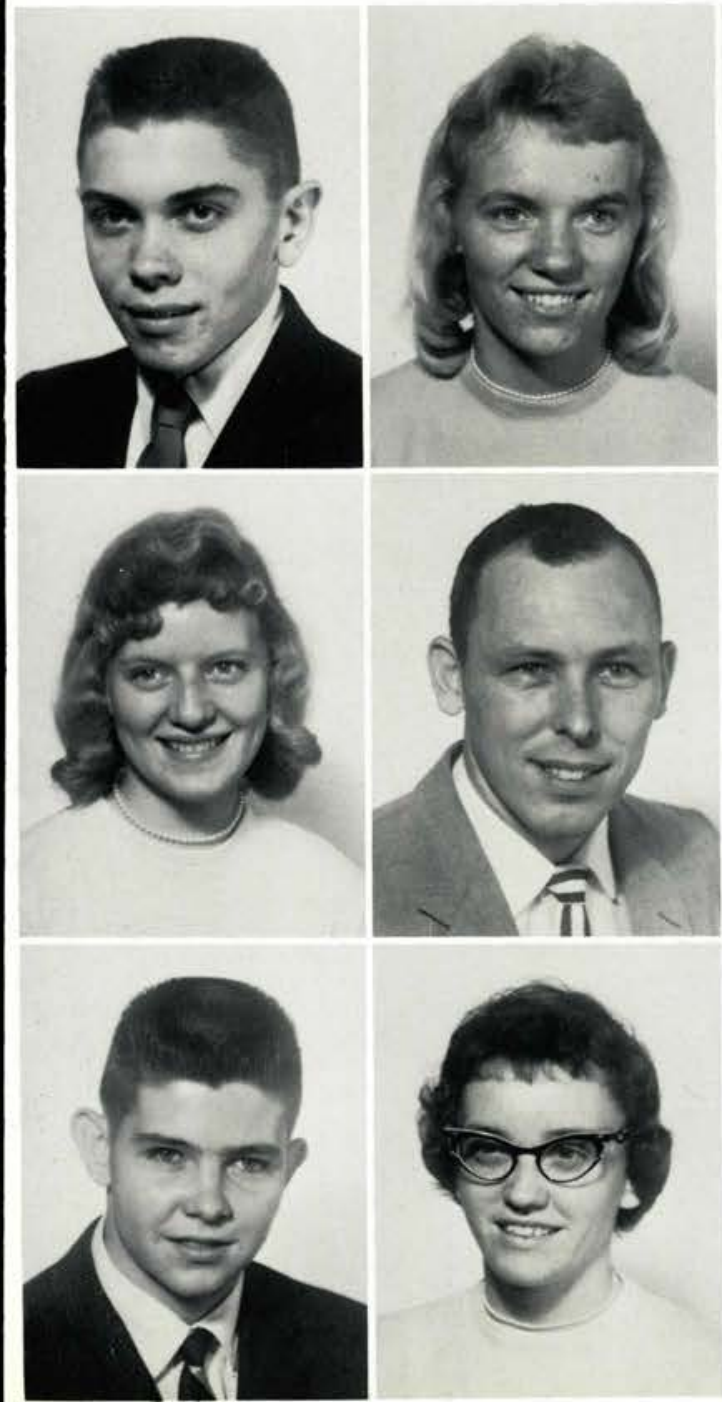

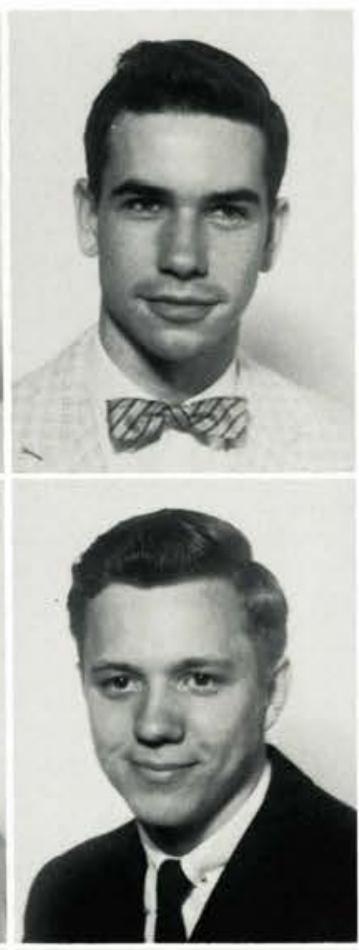

Marcus W. Haseltine, Jr., Treasurer

Butler, Pennsylvania

First Baptist Church

Charlotte Heikes

Chatfield, Minnesota

First Baptist Church

Larry S. Helmick

Traverse City, Michigan

Immanuel Baptist Church

Carol Henson

Overland, Missouri

Lackland Road Baptist Church

Arthur Hicks

North Adams, Michigan

North Adams Baptist Church

Ronald Windall Hoffman

Forestville, Ohio

Evangelical United Brethren

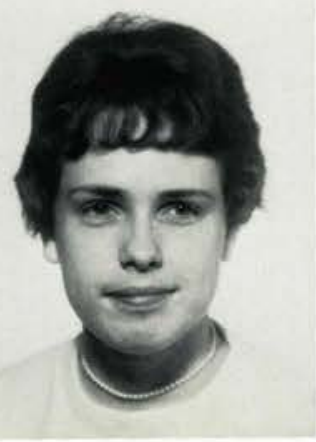

Gary Hogard. Vice President

Allen Park, Michigan

First Baptist Church of Lincoln Park

Doris Hoskey

Flint, Michigan

Riverdale Baptist Church

Elayne Howard

Chicago, Illinois

Belden Avenue Baptist Church 

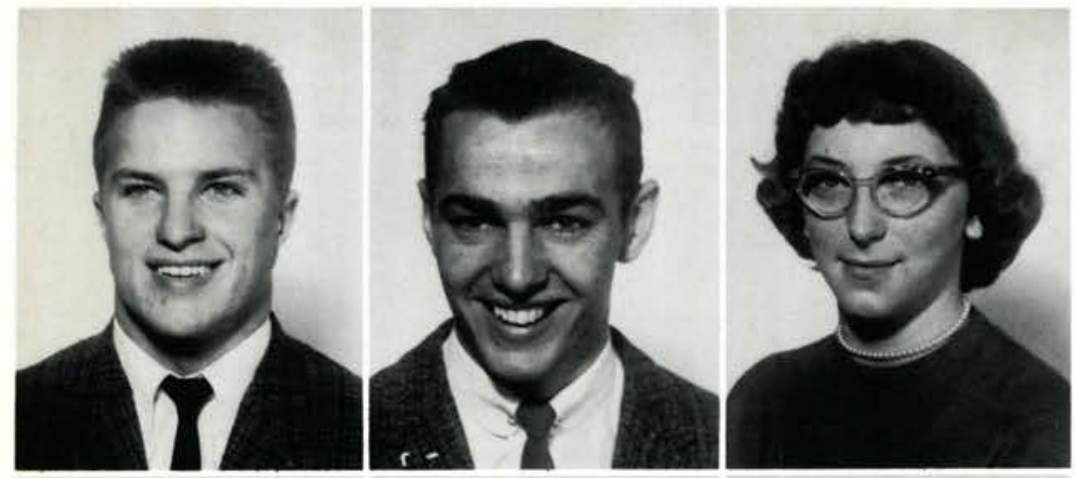

Lynn E. Jefson

Forest City, Iowa

Calvary Baptist Church

David Jeremiah

Cedarville, Ohio

Grace Baptist Church

Wanda Lee Kennedy

Evans City, Pennsylvania

First Baptist Church
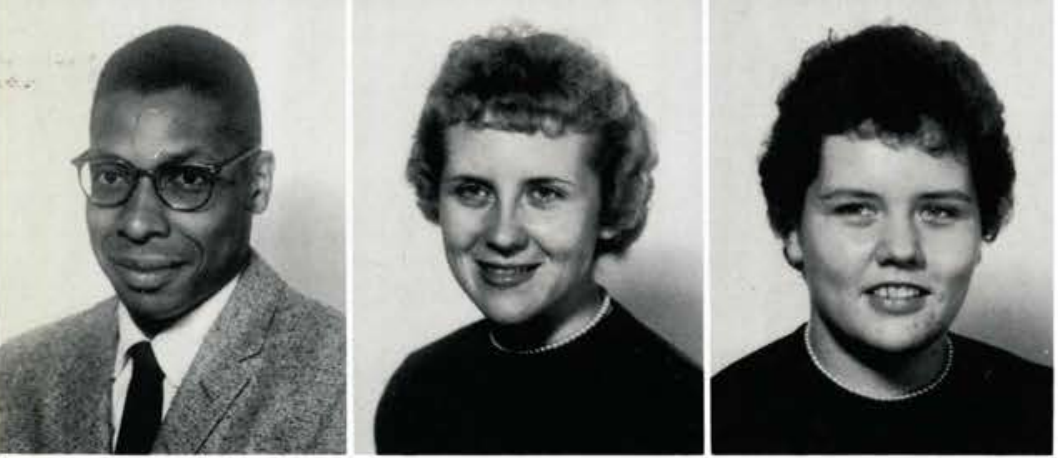

William Keys

Pittsburgh, Pennsylvania

Mount Oliver Baptist Church

Judith Ann Lachman

Lorain, Ohio

Penfield Junction Baptist Church

Patricia Lambert

Rittman, Ohio

First Baptist Church

John Lawlor

Cedarville, Ohio

Grace Baptist Church

Virginia Lowe

Parma, Idaho

Roswell Baptist Church

Gary Luscombe

Gary, Indiana

Central Baptist Church

Janet McClish

Sharon, Pennsylvania

Sharon Baptist Church

Edward Vinton McFann

Mechanicsburg, Ohio

Oak Grove Church

Betty Anne McKeehan

Galion, Ohio

First Baptist Church
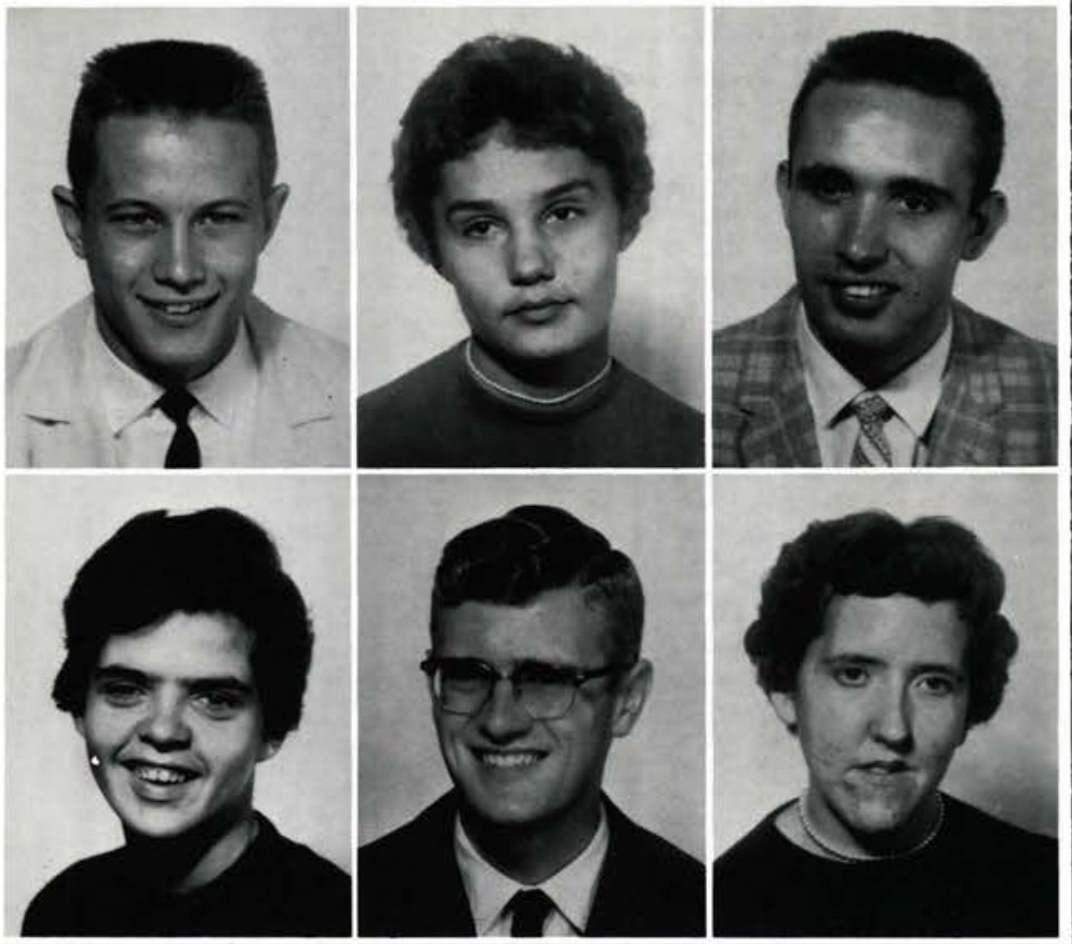

Ronald Mainguth Lock Haven, Pennsylvania First Baptist Church

James Mapes

Jonesville, Michigan

North Adams Baptist Church

Helen Mash

St. Albans, West Virginia

Springhill Baptist Church

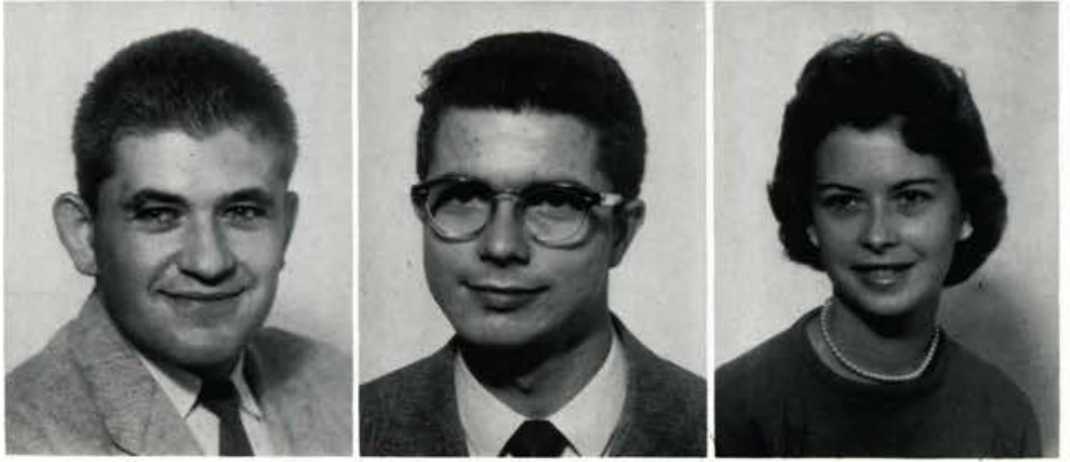



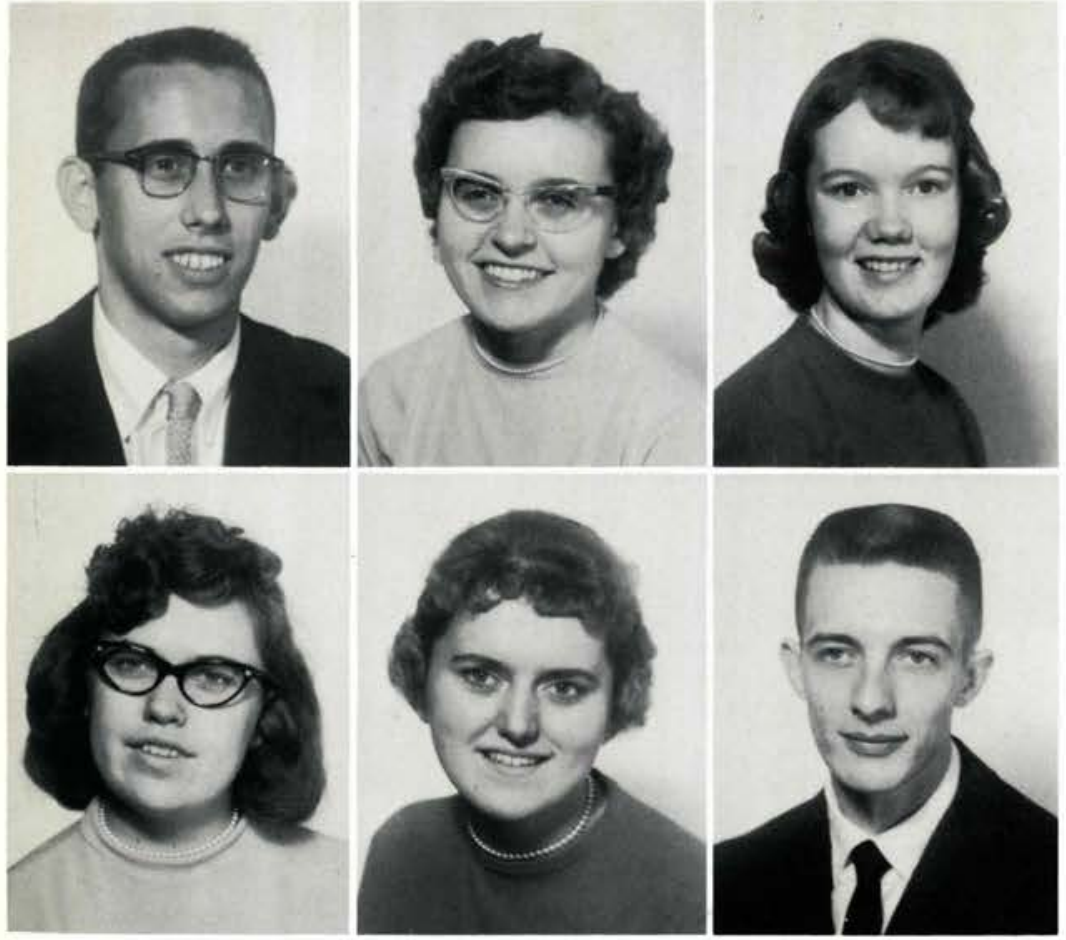

Lauren H. Schenck

Cedarville, Ohio

Hayden Avenue Baptist Church

Patricia Schonscheck

Allen Park, Michigan

Evangel Baptist Church

Camilla Shambaugh

Wilmington, Ohio

Church of Christ

Sarah Shorts

Flint, Michigan

Grace Baptist Church

Sharon Siewiorek

Lorain, Ohio

East Side Baptist Church

Norris H. Smith

Kirkersville, Ohio

Bible Mission Baptist Church

Elizabeth Smythe

Norwalk, Ohio

Calvary Baptist Church

Esther Spieth

La Grange, Ohio

La Grange Baptist Church

Jim Strolle

Newberry, Michigan

First Baptist Church

Barbara Kay Swertfager

Ithaca, New York

Milan Baptist Church

Carol Tatro

Grand Rapids, Michigan

Woodward Ave. Baptist Church

Lily Tobita

Haiku Maui, Hawaii

Paia Baptist Church

Ayris Tyson

Norwalk, Ohio

Calvary Baptist Church

Marilyn Van De Venne

Portland, Michigan

First Baptist Church

Louise Varisco

Strongsville, Ohio

Beebetown Baptist Church
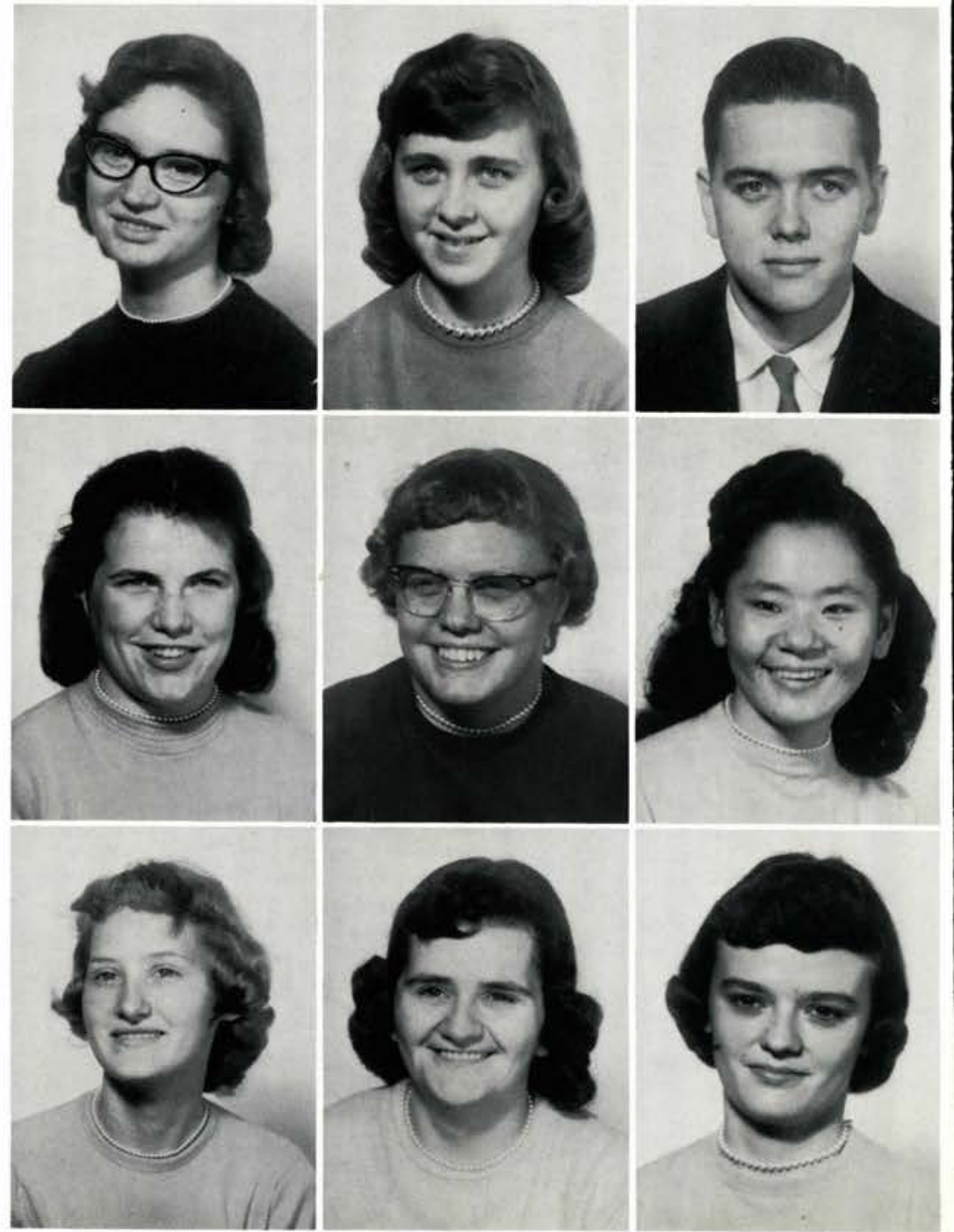
Gerald Wagnitz

Milford, Michigan

First Baptist Church

Cathy Walmsley

Traverse City, Michigan

Immanuel Baptist Church

Bill Warfield

Elmhurst, Illinois

Grace Baptist Church

Nancy Warkentin, Secretary

Waverly, Iowa

Walnut Street Baptist Church

Violet D. Welch

Allen, Michigan

Allen Baptist Church

Ralph Werner Jr.

Columbia Falls, Montana

First Baptist Church
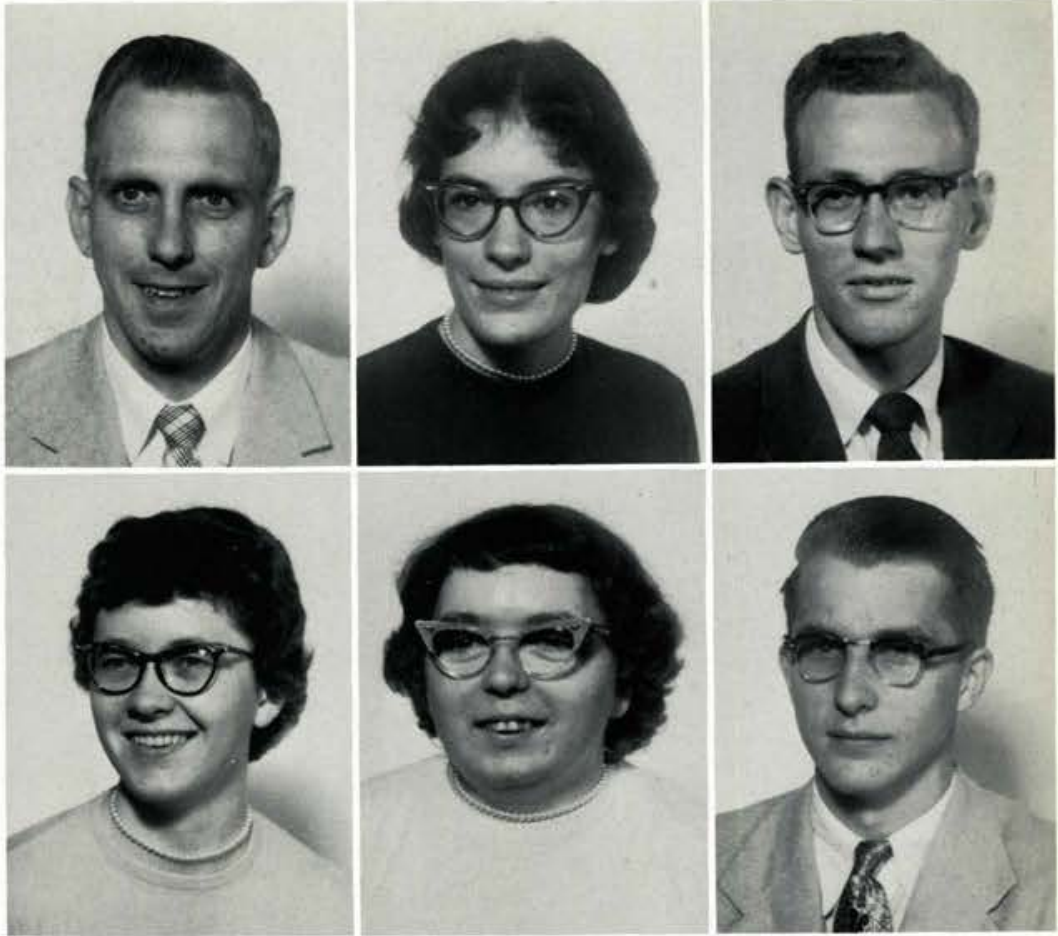

Mary Williams

Lima, Ohio

Christian and Missionary Alliance

William J. Wolf

Litchfield, Michigan

St. Joe Baptist Church

Beverly Woods

Fostoria, Ohio

Fostoria Baptist Church

Emerson L. Wright

Eaton, Ohio

First Baptist Church

Pictures Not Available

Wilton Alexander

Steve Cochenour

Clifford McMullen

Bob Mayo

Gene A. Wright

Harrison, Michigan

First Baptist Church 


\section{Second}

\section{Semester}

\section{Students}

Sharon Addleman

North Adams Baptist

North Adams, Michigan

Robert L. Bell

First Brethren Church

Canton, Ohio
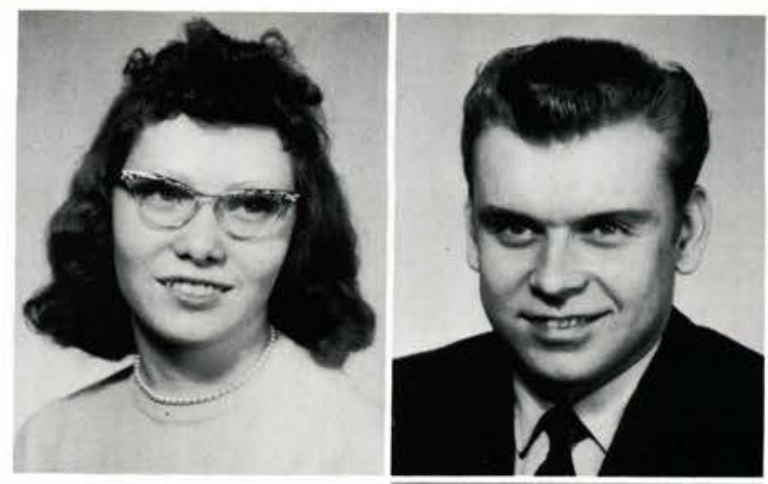

Ben Cullins

Wilson, West Virginia

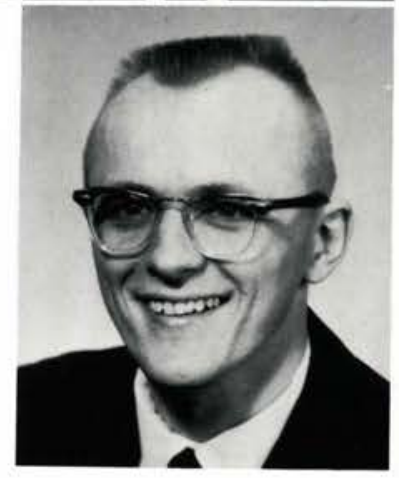

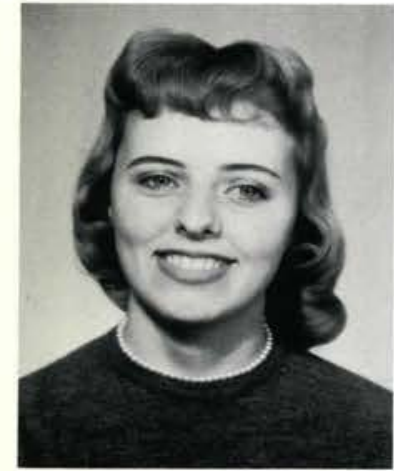
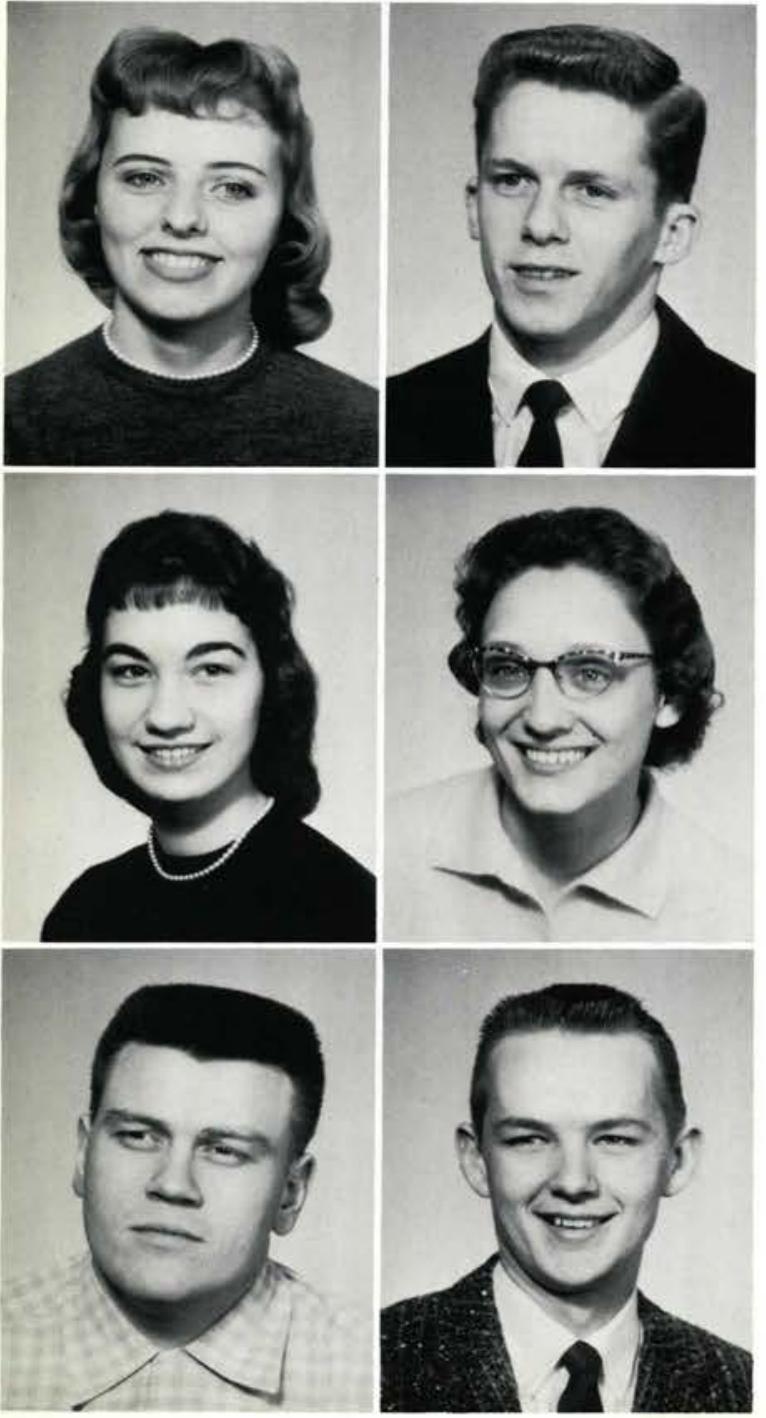

Donna Lee Davis

West Chicago Baptist Church

Detroit, Michigan

William Bryan Jennings Mt. Tabor Baptist Church Beckley, West Virginia

Nancy Shimits

Hayden Avenue Baptist Church

East Cleveland, Ohio

Norma Smith

Calvary Baptist Church

Quincy, Illinois

\section{Not Pictured}

Dale Adams

Earl Dunlap

Robert Kidd

Bill Lane

Carl Stewart

Central Baptist Church

Cedarville, Ohio

Ernestine McCartt

Donald Rickard 
Our Patrons

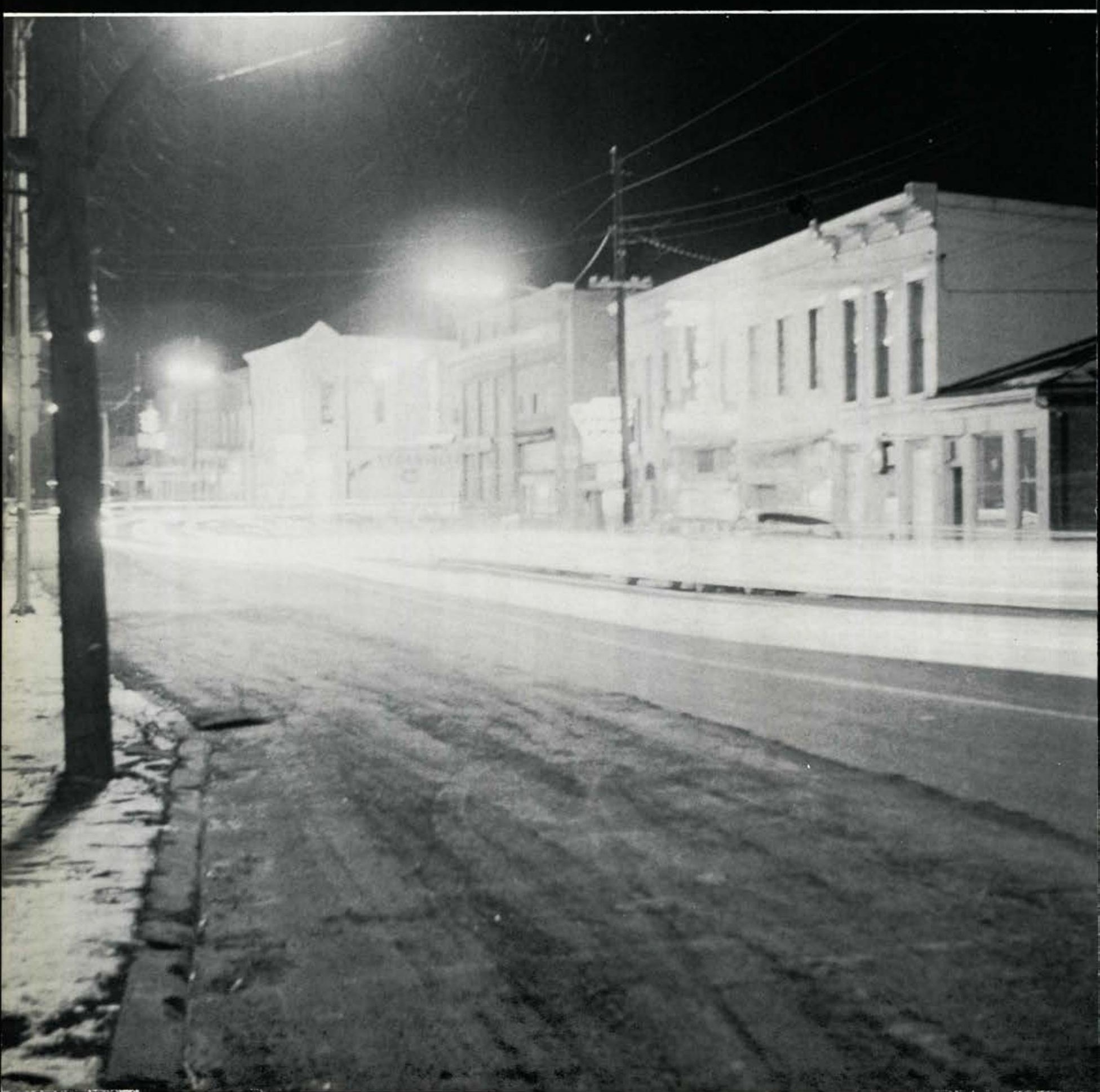




\section{Reco Sporting Goods}

and

Depend On

The Camera Shop

Gift Store

Uniforms

Jackets

Sweaters

for all your photographic needs.

22 West Main Street

Xenia, Ohio

Tel. DR 2-1469

Compliments of

Sports Equipment

Come in and Browse Around

James Bros.

Super Market

Xenia, Ohio

\section{Foodcraft}

\section{Management Corp.}

Congratulations

and

Best Wishes

to the

Graduates

1319 N. Main Street

Dayton 5, Ohio
Chas. W. Kester Co.

Dayton, Ohio

The Independent Towel Co.

Springfield, Ohio

Concord Prov. Co.

Dayton, Ohio

Bakers Supply Co.

Troy, Ohio

Dayton Frozen Foods, Inc.

Dayton, Ohio

Hymans Produce

Xenia, Ohio 


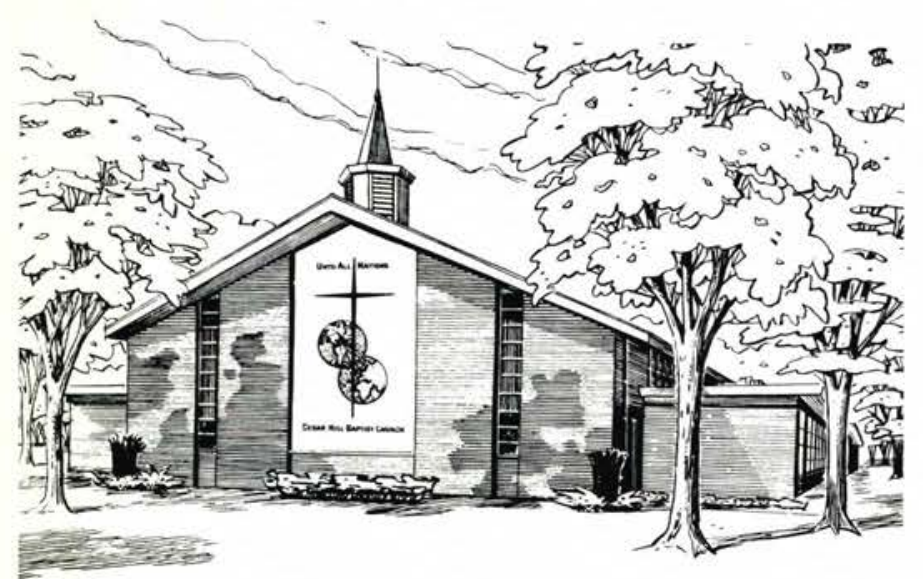

\section{Cedar Hill}

\section{Baptist Church}

John G. Balyo, Pastor

Earl Leiby, Associate Pastor

12601 Cedar Road, Cleveland Heights 6, O.
Greetings and Best Wishes

From the

\section{First Baptist Church}

\section{of Parma, Ohio}

5994 Ridge Road, Parma 29, Ohio

Elliott Horton, Pastor — Tuxedo 4-2990 Parma 34, Ohio

Sunday School 10:00 A.M. Bible Preaching _- 11:00 A.M., 7:30 P.M. Mid-Week Service ____ 7:30 P.M. Wed.

"A Christ Centered Church With a Bible Teaching Ministry"

\section{Bible}

Mission

Baptist

Church

536 Moxahala Avenue

Zanesville, Ohio

Walter G. Yeager, Pastor

\section{FIRST BAPTIST $\mathrm{CHURCH}$}

15344 Lexington Ave.

Harvey, Illinois

\section{Congratulations to the}

\section{Graduating Class of 1960}

"Trust in the LORD with all thine beart; and lean not unto thine own understanding. In all thy ways acknowledge Him, and He shall direct thy paths."

Proverbs 3:5,6

Henry Murdoch, Pastor

James Short,

Director of Christian Education 


\section{Memorial}

Baptist Church

2435 Eakin Road

Columbus, Ohio

Crawfordsville, Indiana

Paul M. Hubble, Pastor

"But sanctify the Lord God in your hearts; and be ready always to give a reason for the hope that is in you, with meekness and fear."

-I Peter 3:15
REIGNS

C. C. Clawson, Pastor

\section{You Are}

\section{Welcome}

to the

\section{Bible Mission}

\section{Baptist Church}

Just off U.S. route 40 east of Reynoldsburg, Ohio

BIBLE

TEACHING

MINISTRY

Llewelyn Thompson, Pastor

\section{First Baptist Church}

Shell Rock, lowa

Pastor: Rev. Harry Stickle
Sunday School

Worship Service

Young People's

Evening Service

Bible Study, Thur.
$9: 30$

$10: 30$ and $7: 30$

Wed. 7:30

\section{"Christ Died for Our Sins"}


NOW! Enjoy the Finest

in Dairy Products ... Produced in

Springfield's Most Modern Self-Serve

Home-Owned Dairy!

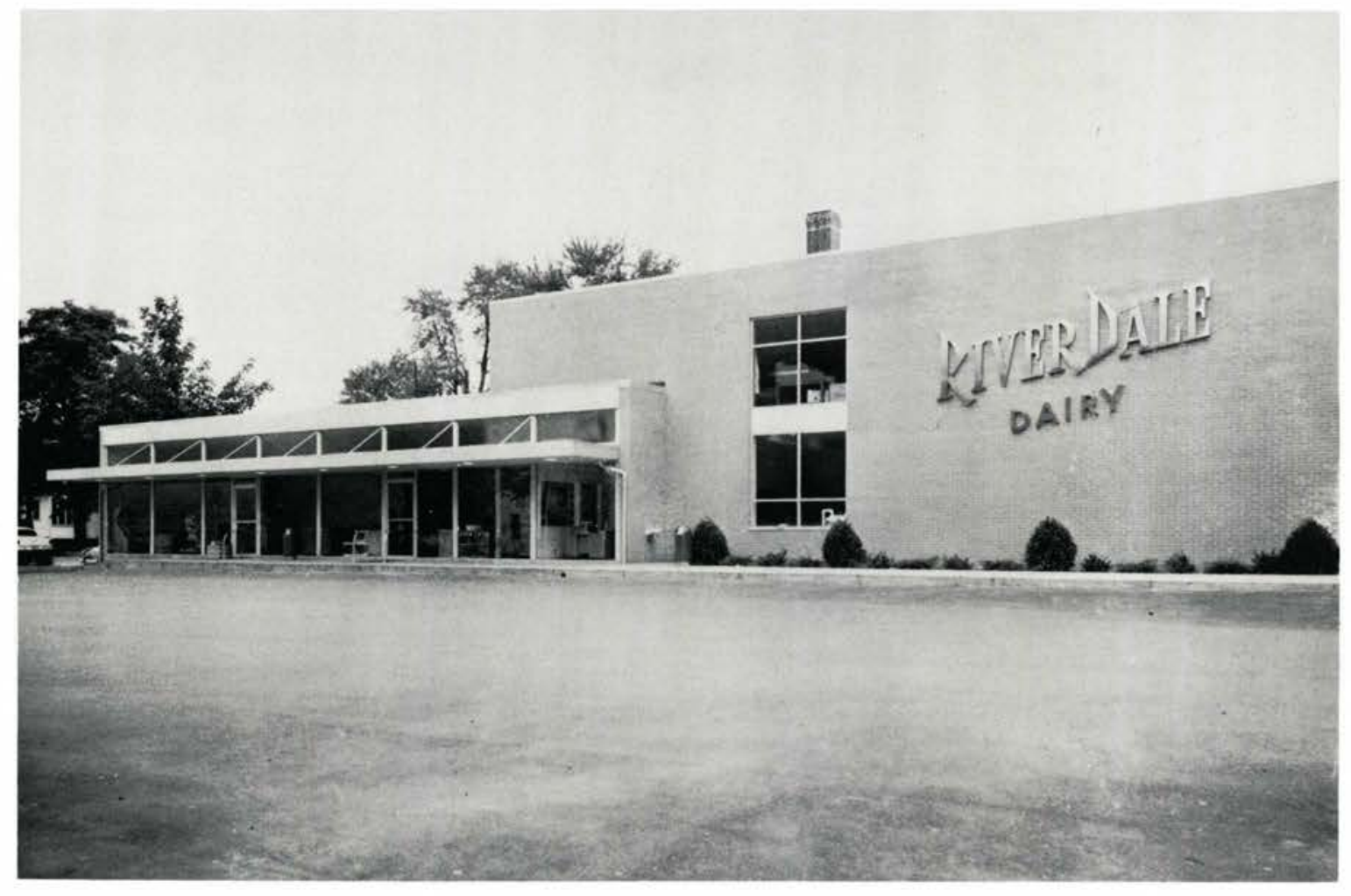

BUT WHERE YOU SAVE

Springfield's Home-Owned, Home-Operated

\section{River Dale}

\section{Dairy}

Corner Selma Road and Oak Street 
WE DESIRE

THE LORD'S BLESSING

TO BE UPON THE

GRADUATES OF 1960

AS THEY CONTINUE

FORWARD WITH HIM.

\section{Huntsburg}

\section{Baptist Church}

Route No. 322

Huntsburg, Ohio

\section{First Baptist Church}

118 West Walnut Street Galion, Ohio

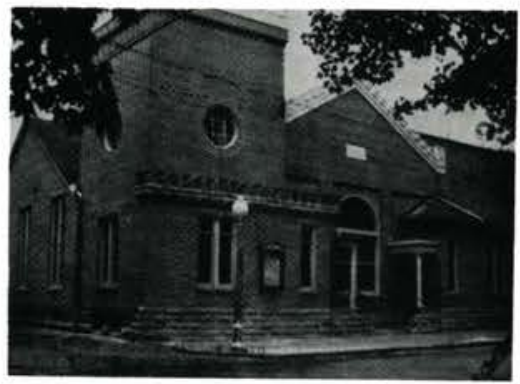

Rev. Wilfred Booth, Pastor SUNDAY

Bible School 9:30 A.M.

Worship Service 10:30 A.M.

Baptist Youth Fellowship _-_ 6:30 P.M.

Gospel Service 7:45 P.M. WEDNESDAY

Prayer and Bible Study 7:30 P.M.
Congratulations to the Class of 1960 !

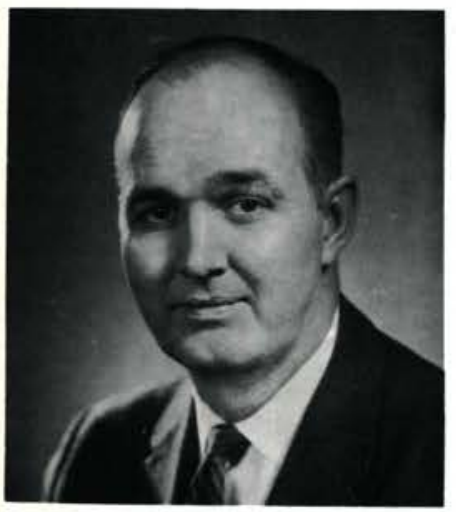

\section{Grace Baptist Church}

Cedarville, Ohio

A. Donald Moffat, Pastor

A Bible Centered Ministry

We Preach Christ

Crucified - Buried - Risen

Coming Again

\section{First Baptist Church}

Faribault, Minnesota

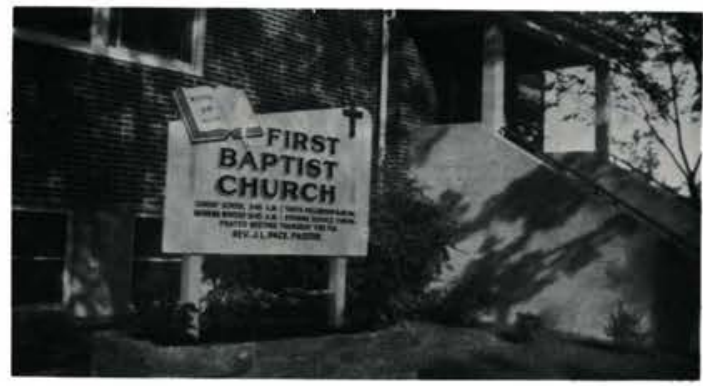

Services:

Sunday School 9:45 A.M. Morning Worship 10:45 A.M.

Youth Fellowship 6:30 P.M.

Evening Service 7:45 P.M.

Prayer Meeting, Thursday _-_ 7:30 P.M.

"On the same corner with the same Gospel for a Century." 


\section{Berea Baptist Church}

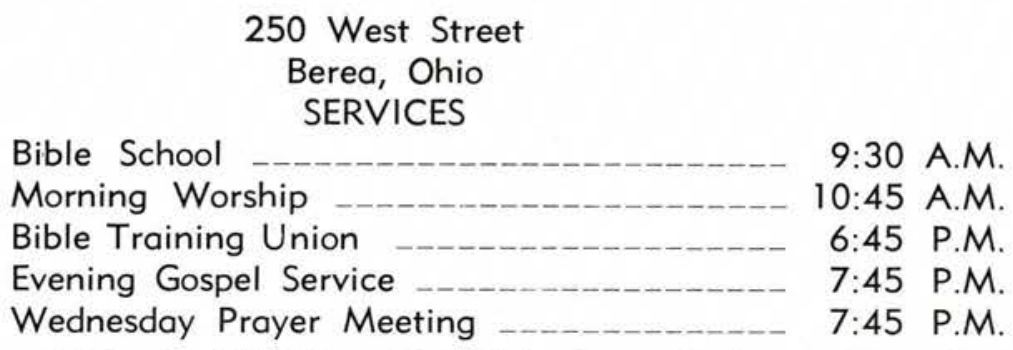

"That in All Things He Might Have the Pre-eminence."

Earl V. Willetts, Pastor

\section{First Baptist Church}

120 Main Street

Hamburg, New York

"A Friendly Church in a Friendly Village."

May God's Richest and Best Be Your Portion

in Your Training and Future Service for Him.

ALVIN G. ROSS, Pastor MEL W. NEGLEY, Associate

\section{Grace Baptist Church \\ Austin, Minnesota}

THERE IS A WELCOME HERE FOR YOU

Sunday School

We Study the Word of God

Morning Worship

9:45 A.M.

We Worship the God of the Word

10:50 A.M.

Youth Meetings

6.30 P.M.

We prepare to Serve.

Evening Service

7:30 P.M. We Evangelize.

Mid-week Prayer and Bible Study - Thursday 128
WE PRESENT

Via the Blood

A Living Lord and Saviour

"Christ died for our sins - was buried - and rose again the third day -"

1 Cor. 15:3-4 $\checkmark i a$ the Book

A Holy Bible

The Bible not only contains the Word of God - it is The Word of God.

"All scripture is given by inspiration of "God."

Via The Blessed Hope

II Tim. 3:16

A Coming King

"Looking for that blessed hope, and the glorious appearing of the great God and our Saviour Jesus Christ." 


\section{First Reformed Church \\ Detroit and Church Streets \\ Xenia, Ohio}

\section{(Where the Bible is Taught) \\ Russell Mayer, Pastor}

INDEPENDENT, FUNDAMENTAL, PREMILLENNIAL

A Friendly Church

\section{Calvary Baptist Church}

3550 West 25 Street

Cleveland 9, Ohio

George R. Gibson, Pastor

SUNDAY SERVICES

Bible School

Morning Worship

Youth Fellowship

Evangelistic Hour

Prayer Service

WESNESDAY

9:30 A.M.

10:30 A.M.

6:30 P.M.

7:30 P.M.

7:30 P.M.

Service at the City Mission every second Tuesday

Cheer Service Eastern Star Home every fourth Sunday

\section{Emmanuel}

Baptist Church

Grand at Waite

Toledo, Ohio

L. George Hunt

Pastor

SUNDAY SERVICES

9:30 Sunday School

10:45 Morning Worship

6:30 Youth Groups

7:30 Evening Service

Midweek Prayer Hour

Thursday 7:30 


\section{Chaplin Cleaners}

Laundry Service

Cleaning

Shoe Repair

Pressing

CEDARVILLE, OHIO

Compliments of

\section{Cedarville Hardware}

Progressive Hardware Service

CEDARVILLE, OHIO

PHONE SO 6-1941

Your GE Appliance Dealer
Compliments

of

Stokes

Motor Company

South Main Street

CEDARVILLE, OHIO

Phone SO 6-4021

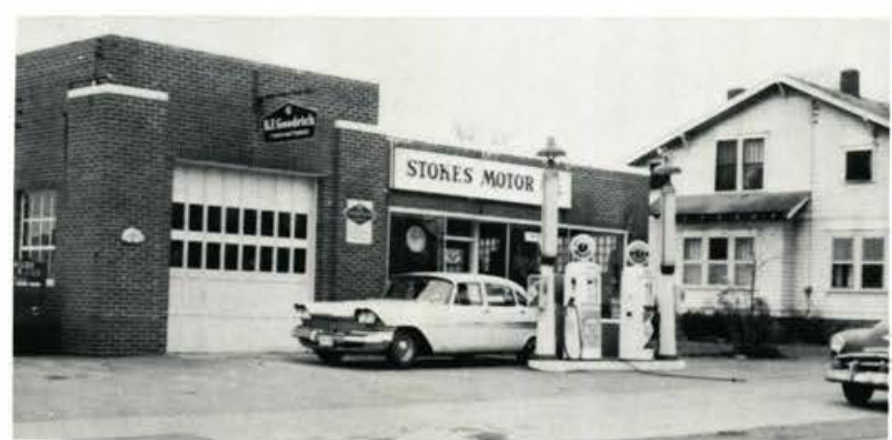

\section{Harner's}

\section{Cedarville Market}

Meats

Produce

Groceries

Phone SO 6-1201

CEDARVILLE, OHIO

\section{Cedarville}

\section{Feed \& Grain Co.}

Grain, Feed, Seed, Coal, Salt, Wool, Fertilizer

Builder's Supplies and Fencing CEDARVILLE, OHIO

Phone: Dial SO 6-2021

\section{James Cut-Rate}

THE REXALL STORE

Phone SO 6-1771

CEDARVILLE, OHIO

Wilson Everhart, Proprietor 


\section{Miami De}

Complete Facilities Ready to Serve You

CEDARVILLE, OHIO and

YELLOW SPRINGS, OHIO

Member of the

FEDERAL DEPOSIT

INSURANCE CORPORATION

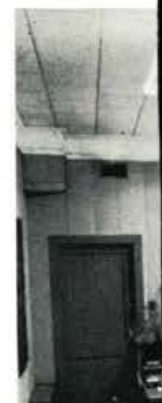

Randall

Rheubert's Market

North Main Street

CEDARVILLE, OHIO
Stormont Inc.

Phone SO 6-1031

CEDARVILLE OHIO
$\&$

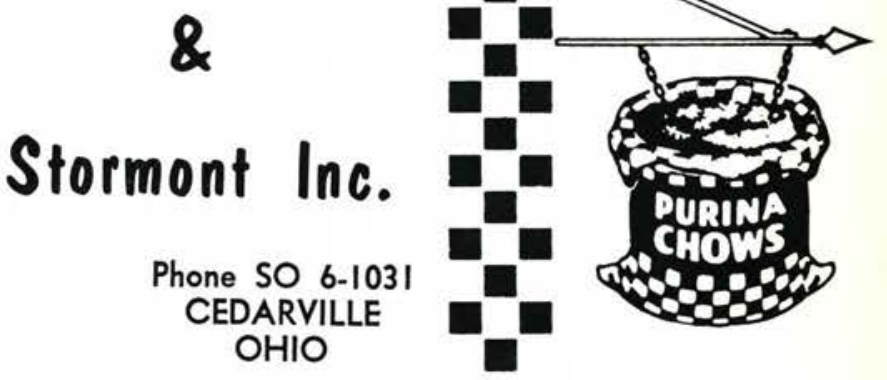

Beaty \& Finney

Shell Service

Tires, Batteries

Motor Tuneup
Chevrolet

Cadillac

Xenia and Fairborn

Ohio

Green County's Largest Auto Dealer 


\section{Congratulations}

\section{and}

\section{Best Wishes}

To The

Seniors

From Your Friends

\section{Milner Electric Co.}

Cleveland, 14, Ohio

MUSIC

Is Our Business

\section{Band Box}

Music Center

31 West Main Street Xenia, Ohio

Compliments

J.C. Penney Co.

DEPARTMENT STORE

XENIA, OHIO — Ph. DR 2-6976

SHOP PENNEY'S

You'll live better, you'll save!
15 W. Main

Xenia

Compliments of

\section{Geyer's}




\title{
Congratulations Seniors
}

\author{
of \\ 1960
}

From

Class of ' 63

"Stand fast therefore in the liberty wherewith

Christ hath made us free." Gal. 5:1a

\section{Congratulations}

to

The Class of 1960

from

The Class of 1962

"We Enter to Learn and Go Forth to Serve" 



$+4 e^{2}$
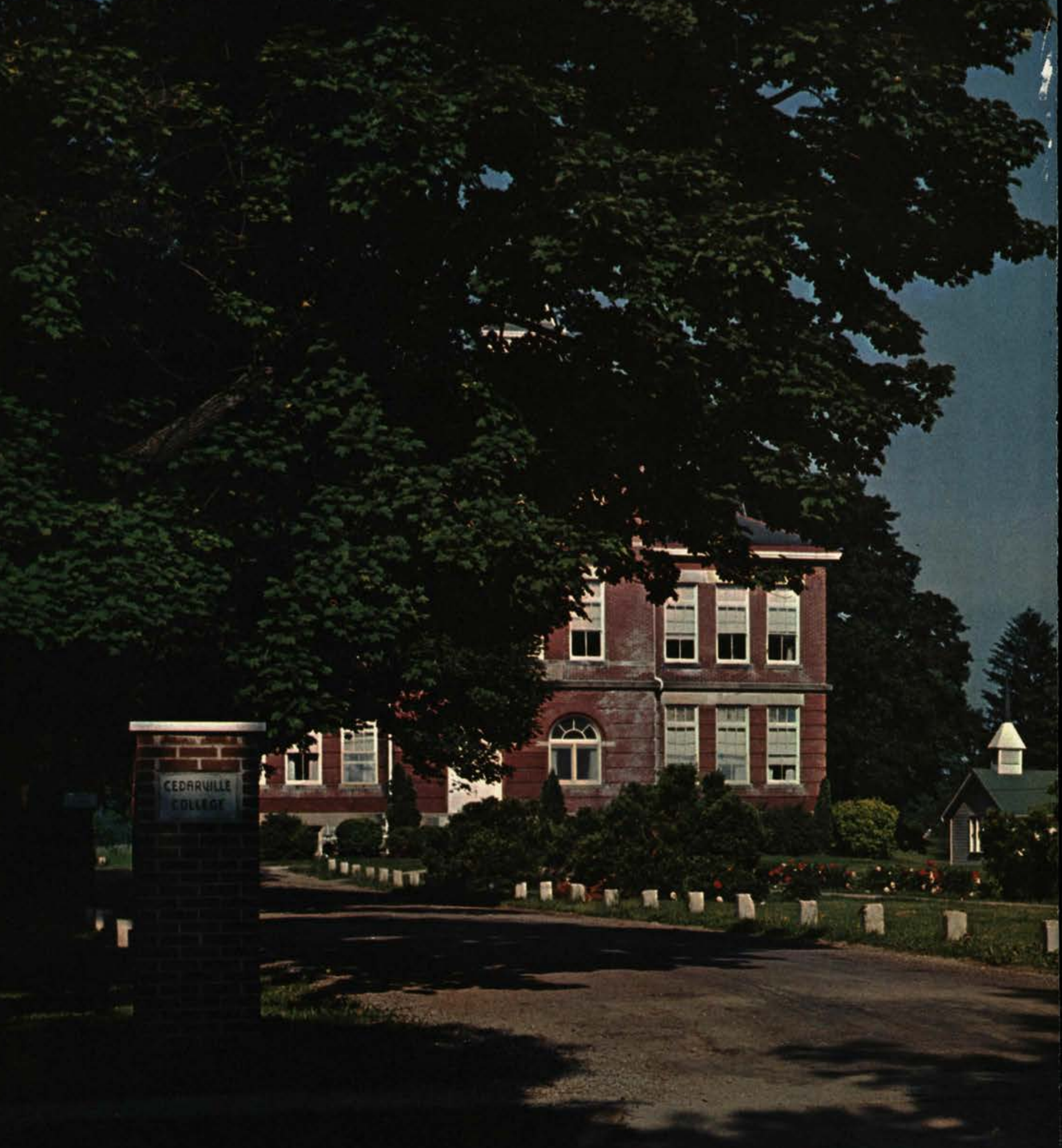


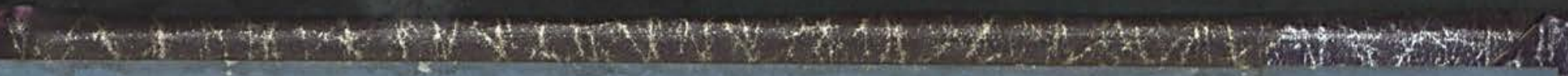

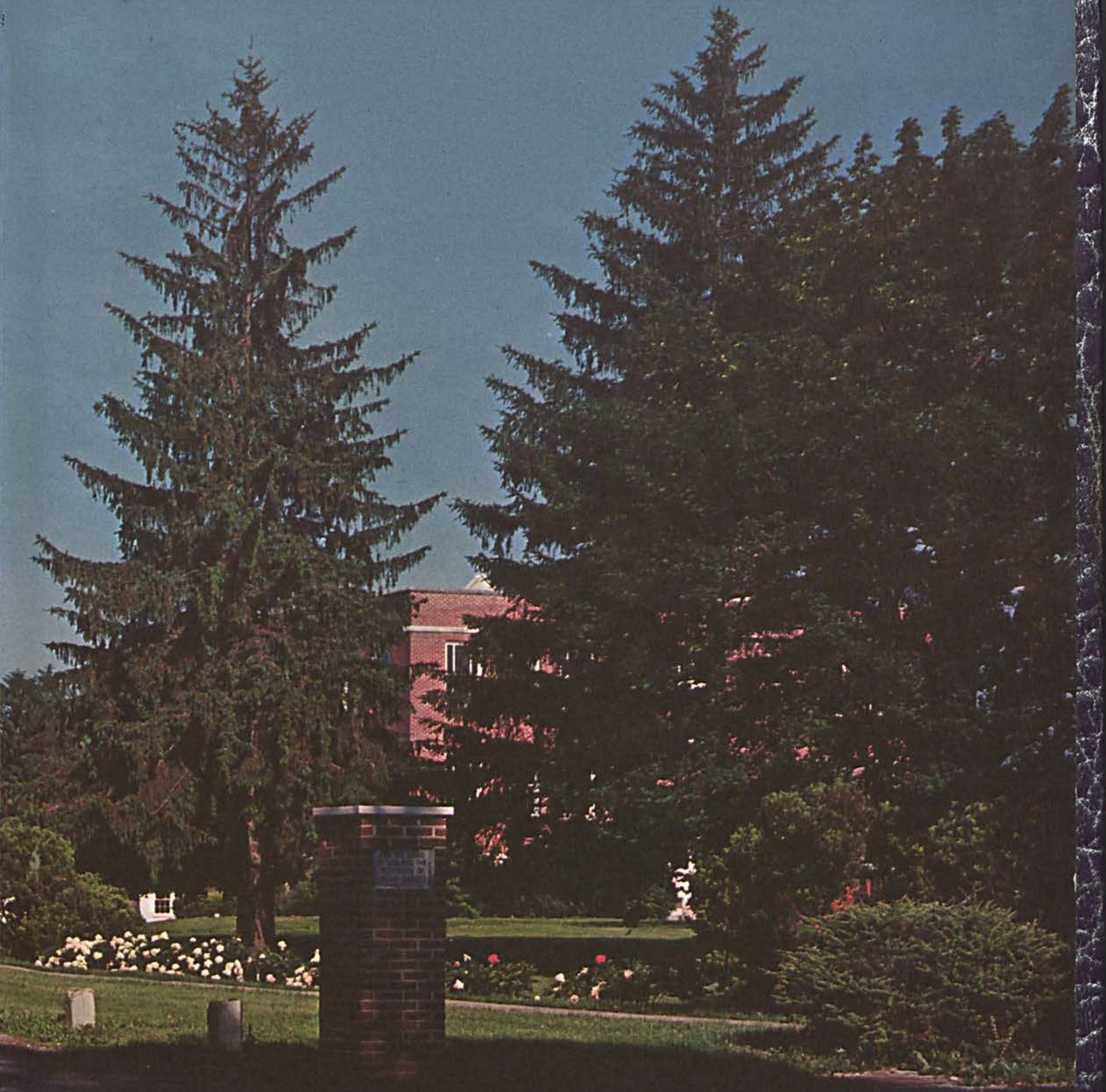



(25)

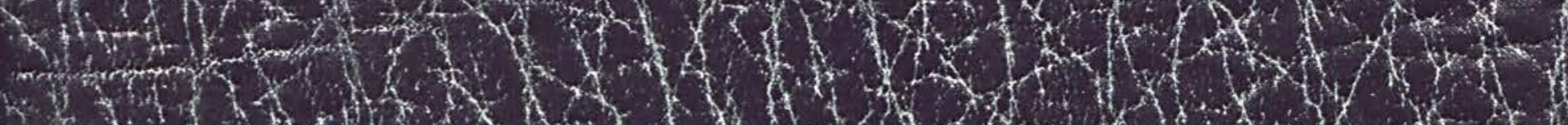
(1)

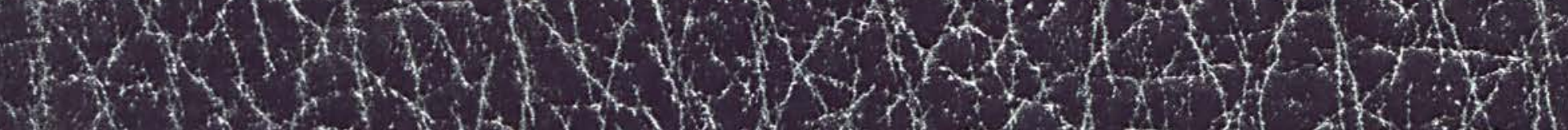
(3)

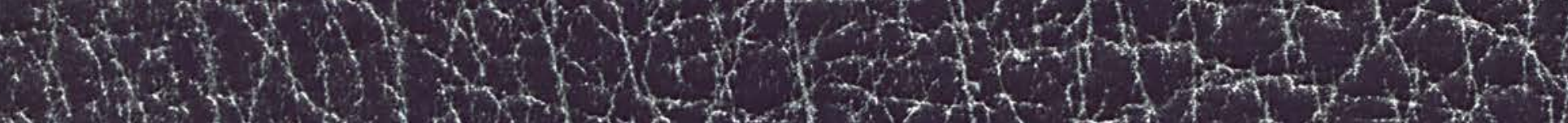

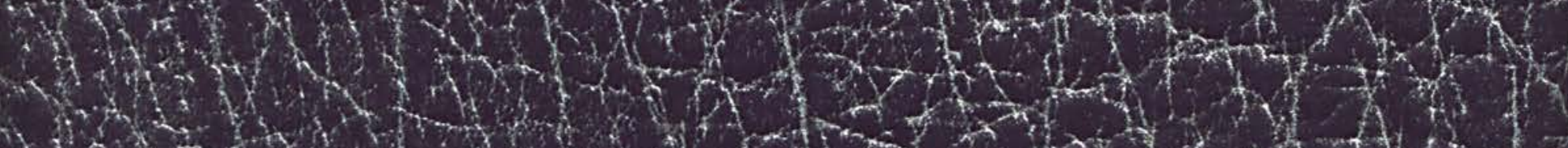

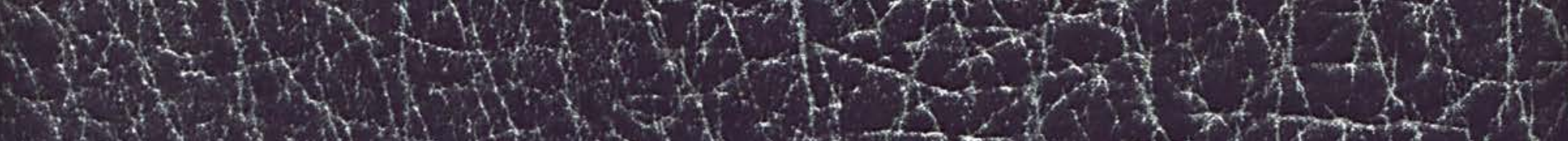

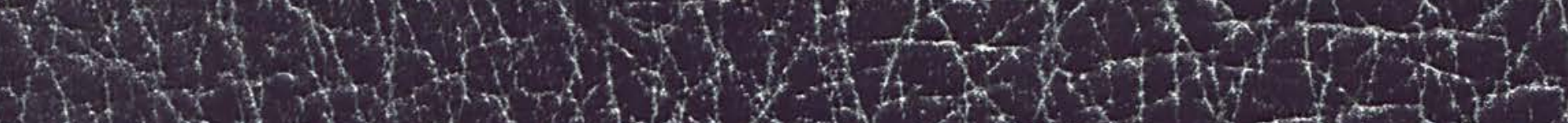

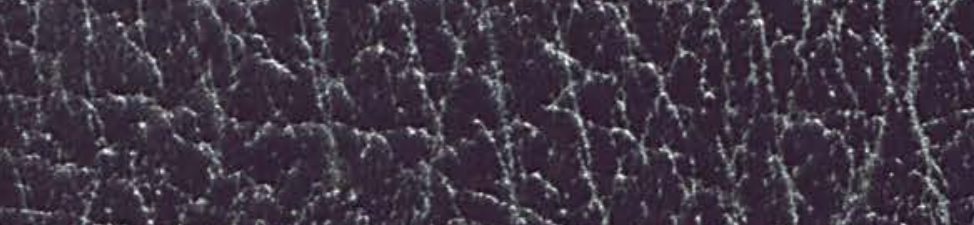
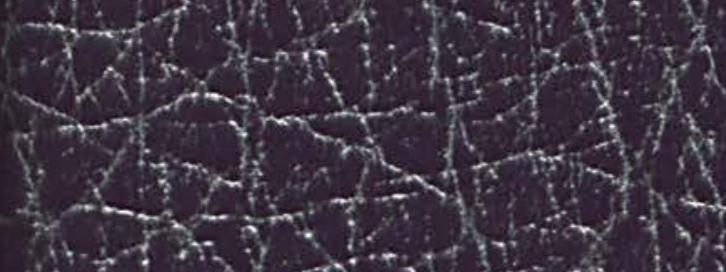

$$
(4+2)
$$

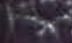

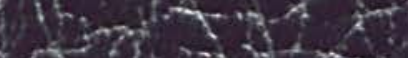$$
x+4<0
$$

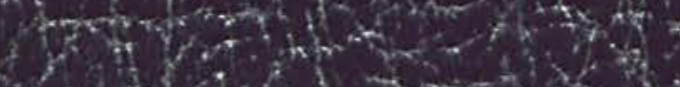$$
+2+2+2
$$ 